\title{
EGYPTIAN ARCHEOLOGY
}

\author{
BY \\ G. Maspero.
}

ENGLISH TRANSLATION

BY

AMELIA B.EDWARDS. 


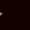

$\lambda$ 

EGYPTIAN ARCHÆOLOGY. 



\section{EGYPTIAN ARCHÆOLOGY.}

BY

\section{G. Ma A P ERO, D.C.L., Oxon.,}

MEMBER OF THE INSTITUTE OF FRANCE ; PROFESSOR AT THE COLLÈGE DE FRANCH HONORARY FELLOW OF QLEEN'S COLLEGE, OXFORD ;

IICE-PRESIDENT OF THE EGYPT EXPIORATION FUND, ETC., ETC., ETC.

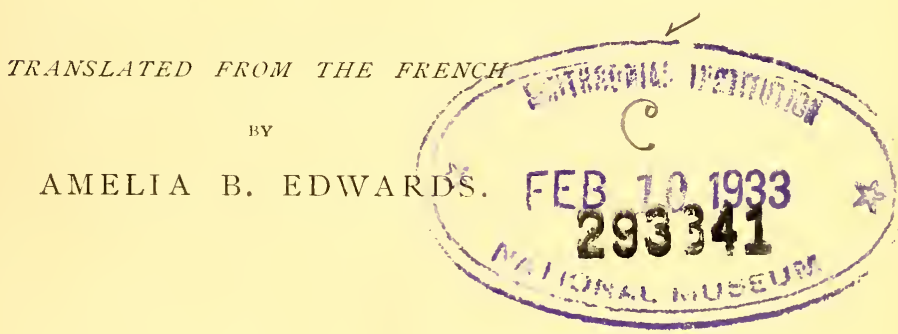

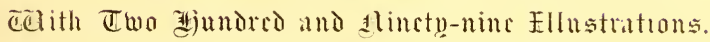

NEW YORK: G. P. PUTNAM'S SONS.

LONDON: H. GREVEL \& CO. I 888. 

TO put this book into English, and thus 1 to hand it on to thousands who might not otherwise have enjoyed it, has been to me a very congenial and interesting task. It would be difficult, I imagine, to point to any work of its scope and character which is better calculated to give lasting delight to all classes of readers. For the skilled archæologist, its pages contain not only new facts, but new views and new interpretations; while to those who know little, or perhaps nothing, of the subjects under discussion, it will open a fresh and fascinating field of study. It is not enough to say that a handbook of Egyptian Archæology was much needed, and that Professor Maspero has given us exactly what we required. He has done much more than this. He has given us a picturesque, vivacious, and highly original volume, as 
delightful as if it were not learned, and as instructive as if it were dull.

As regards the practical side of Archæology, it ought to be unnecessary to point out that its usefulness is strictly parallel with the usefulness of public museums. To collect and exhibit objects of ancient art and industry is worse than idle if we do not also endeavour to disseminate some knowledge of the history of those arts and industries, and of the processes employed by the artists and craftsmen of the past. Archæology, no less than love, "adds a precious seeing to the eye" ; and without that gain of mental sight, the treasures of our public collections are regarded by the general visitor as mere "curiosities"-flat and stale for the most part, and wholly unprofitable.

I am much indebted to Mr. W. M. Flinders Petrie, author of The Pyramids and Temples of Gizeh, for kindly translating the section on "Pyramids," which is entirely from his pen. I have also to thank him for many valuable notes on subjects dealt with in the first three chapters. To avoid confusion, I have numbered these notes, and placed them at the end of the volume. 
My acknowledgments are likewise due to Professor Maspero for the care with which he has read the proof-sheets of this version of his work. In departing from his system of orthography (and that of Mr. Petrie) I have been solely guided by the necessities of English readers. I foresee that Egyptian Archaology will henceforth be the inseparable companion of all English-speaking travellers who visit the Valley of the Nile; and for that reason I have adopted the spelling of Egyptian proper names as given by the author of "Murray's Handbook for Egypt."

Touching my own share in the present volume, I will only say that I have tried to present Professor Maspero's inimitable French in the form of readable English, rather than in a strictly word-for-word translation; and that with the hope of still further extending the usefulness of the book, I have added some foot-note references.

AMELIA B. EDIVARDS.

Westbury-on-Tryir, August, 1887. 


\section{CONTENTS.}

PREFACE, BY THE TRANSLATOR

CHAPTER I.

\section{ARCHITECTURE-CIVIL AND MILITARY.}

$\S$ I. Houses:-Bricks and Brickmaking-Foundations-Materials -Private Dwellings-Decoration . . . . . 2

$\S$ 2. FORTRESSES:-Walls-Gates-Bastions-Salients-Migdols, etc. . . . . . . . . . . I6

§ 3. Public Works :-Roads-Bridges-Storehouses-Canals -Lake Mœris-Dams-Reservoirs-Quarries . . 30

\section{CHAPTER II.}

\section{RELIGIOUS ARCHITEC'TURE.}

§. Materials and Principles OF Construction:Materials of Temples-Foundations of Temples-Sizes of Blocks-Mortars-Mode of hoisting Blocks-Defective Mason's Work-Walls - Pavements -- Vaultings - Supports - Pillars and Columns - Capitals - Lotus-flower Capitals-Lotus-bud Capitals-Hathor-headed Capitals .

§ 2. Temples :-Temple of the Sphinx--Temple of Elephantine - Temple at El Kab-Temple of Khons-Management of Light-Levels-Crypts-Temple of Karnak-Temple of Luxor-Philæ-The Speos, or Grotto-temple-Speos of Horemheb-Rock-cut Temples of Aboo SimbelTemple of Dayr-el-Baharee - Temple of Abydos-Sphinxes-Crio-sphinxes . . . . . 
\$ 3. Decoration:-Principles of Decoration-The Temple a Symbolic Representation of theWorld-Decoration of Parts nearest the Ground-Dadoes - Bases of Columns-Decoration of Ceilings-Decoration of Architraves---Decoration of Wall-surfaces-Magical Virtues of Decoration-Decoration of Pylons-Statues-Obelisks-Libation-tables-AltarsShrines-Sacred Boats-Animated Statues of Deities

\section{CHAPTER III.}

\section{TOMBS.}

I. Mastabas :-Construction of the Mastaba-The Door of the Living, and the Door of the Dead-The Chapel-Wall Decorations-The Double and his Needs-The SerdabThe Portrait Statues-The Sepulchral Chamber . .

$\$ 2$. Pyramids :-Plan of the Pyramid comprises three leading Features of the Mastaba-Materials of Pyramids-Orientation-Pyramid of Khoofoo-Pyramids of Khafra and Menkara-Step-pyramid of Sakkarah--Pyramid of UnasDecoration of Pyramid of Unas-Group of DashoorPyramid of Meydoom . . . . . . .

§ 3. Tombs of the Theban Empike; The Catacombs:Pyramid-mastabas of Abydos... Pyramid-mastabas of Drah Aboo'l Neggah-Rock-cut tombs of Beni Hassan and Syene-Rock-cut tombs of Siout-Wall-decoration of Theban Catacombs-Tombs of the Kings of the Eighteenth Dynasty at Thebes - Valley of the Tombs of the Kings-. Royal Catacombs-Tomb of Seti I.-Wall-decorations of Royal Catacombs - Funerary Furniture of CatacombsUshabti-Amulets-Common Graves of the Poor . .

\section{CHAPTER IV.}

\section{PAINTING AND SCULPTURE.}

$\$$ I. Design AND Composition :-Supposed Canon of Proportion-Drawing Materials-Sketches-Illustrations to the Book of the Dead-Conventional Treatment of Animals, and of Human Figures-Naturalistic Treatment-Composition-Grouping-Wall-paintings of Tombs-A Funerary Feast-A Domestic Scene-Military Subjects-Perspective-Parallel between a Wall-painting in a Tomb at Sakkarah and the Mosaic of Palestrina . . . . 164 
§2. Technical Processes:-The Preparation of SurfacesOutline-Sculptors' Tools - Iron and Bronze ToolsImpurity of Iron-Methods of Instruction in SculptureModels-Methods of cutting Various Stones-Polish-Painted Sculptures - Pigments - Conventional Scale of Colour-Relation of Painting to Sculpture in Ancient

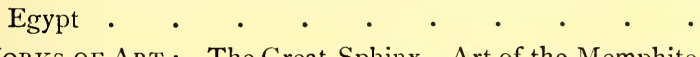

$\S$ 3. Works OF ART :-The Great Sphinx-Art of the Memphite School - Wood-panels of Hosi-Funerary StatuesThe Portrait-statue and the Double--Chefs d'auvre of the Memphite School-The Cross-legged Scribe-Diorite Statue of Khafra-The Wooden Man of Boulak-The Kneeling Scribe-The Dwarf Khnumhotep-Rahotep and Nefert-Royal Statues of the Twelfth Dynasty-Hyksos Sphinxes of Tanis-Theban School of the Eighteenth Dynasty-Colossi of Amenhotep III.-New School of Tell-el-Amarna-Its Superior Grace and Truth-Works of Horemheb-School of the Nineteenth Dynasty-Colossi of Rameses II.-Decadence of Art begins with Menepthah -Ethiopian Renaissance - Saite Renaissance - The Hippopotamus of Nitocris-The Attitudes of StatuesSaite Innovations--Greek Influence upon Egyptian Art - The Ptolemaic and Roman Periods-The School of Meroë-Extinction of Egyptian Art . . . .

CHAPTER V.

\section{THE INDUSTRIAL ARTS.}

$\S$ I. Stone, Clay, and Glass :-Precious Stones-Lapidary Art - Beads and Amulets - Scarabæi - Statuettes Libation Tables-Perfume Vases-Kohl-pots-PotteryClay-Glazes - Red and Painted Wares - UshabtiFunerary Cones-Painted Vases-"Canopic" VasesClay Sarcophagi-Glass-Its Chemical ConstituentsClear Glass-Coloured Glass-Imitations of Precious Stones in Glass-Glass Mosaics-Miniature Objects in Coloured Glass-Glass Amulets-Coloured Glass Vases of the Style called the "False Murrhine"-EnamelsThe Theban Blue-The Enamels of Tell-el-AmarnaEnamelled Ushabti of Amen Ptahmes-Enamelled Tiles of the Step-pyranid at Sakkarah-Enamelled Tiles of Tell-el-Yahoodeh . 
§ 2. Wood, Ivory, Leather, and Textile Fabrics :-Bone and Ivory-Elephant Tusks-Dyed Ivory-Egyptian Woods-Wooden Statuettes-Statuette of Hori-Statuette of Naï-Wooden Toilet Ornaments-Perfume and Unguent Spoons-Furniture-Chests and Coffers-Mummy-cases-Wooden Effigies on Mummy Cases-Huge Outer Cases of Ahmes Nefertari and Aah-hotep-Funerary FurnitureBeds - Canopies - Sledges-Chairs-Stools - ThronesWoven Textures-Methods of Weaving-Leather-Breastbands of Mummies-Patchwork Canopy in Coloured Leather of Princess Isi-em-kheb-Embroideries-Muslins -Celebrated Textiles of Alexandria . . . .

$\S$ 3. Metals :-Iron-I.ead--Bronze-Constituents of Egyptian Bronze-Domestic Utensils in Bronze--Mirrors-Scissors -Bronze Statuettes-The Strogonoff Bronze-The Posno Bronzes-The Lion of Apries-Gilding-Gold-platingGold-leaf-Statues and Statuettes of Precious Metals-. The Silver and Golden Cups of General Tahuti-The Silver Vases of Thmuis-Silver Plate-Goldsmith's Work - Richness of Patterns-Jewellery-Funerary Jewellery -Rings - Seal-rings-Chains - The Jewels of Queen Aahhotep-The Ring of Rameses II. - The Ear-rings of Rameses IX.-The Bracelet of Prince Psar-Conclusion . 296 


\title{
EGYPTIAN ARCHEOLOGY.
}

\author{
CHAPTER I. \\ ARCHITECTURE-CIVIL AND MILITARY.
}

Archæologists, when visiting Egypt, have so concentrated their attention upon temples and tombs, that not one has devoted himself to a careful examination of the existing remains of private dwellings and military buildings. Few countries, nevertheless, have, preserved so many relics of their ancient civil architecture. Setting aside towns of Roman or Byzantine date, such as are found almost intact at Koft (Coptos), at Kom Ombo, and at El-Agandeeyeh, one-half at least of ancient Thebes still exists on the east and south of Karnak. The site of Memphis is covered with mounds, some of which are from fifty to sixty feet in height, each containing a core of houses in good preservation. At Tell-el-Maskhutah, the granaries of Pithom are yet standing; and at Sān (Tanis) and Tell Basta (Bubastis), the Ptolemaic and Saitic cities contain quarters of which a plan might yet be made (Note I). I here refer to none save well-known places; but in many localities which escape the traveller's notice, there may be seen ruins of private dwellings which date back to the age of the Ramessides, or to perhaps a still earlier period. As regards for- 
tresses, there are two in the town of Abydos alone, one of which is at least contemporary with the Sixth Dynasty; while the ramparts of $\mathrm{El} \mathrm{Kab,} \mathrm{of} \mathrm{Kom-el-}$ Ahmar, of El-Hibéh,* and of Dakkeh, as well as part of the fortifications of Thebes, are still standing, and await the architect who shall deign to make them an object of serious study.

\section{I.-Private Dwellings.}

The soil of Egypt, periodically washed by the inundation, is a black, compact, homogeneous clay, which becomes of stony hardness when dry. From immemorial time, the fellaheen have used it for the construction of their houses. The hut of the poorest peasant is a mere rudely-shaped mass of this clay. A rectangular space, some eight or ten feet in width, by perhaps sixteen or eighteen feet in length, is enclosed in a wickerwork of palm-branches, coated on both sides with a layer of mud. As this coating cracks in the drying, the fissures are filled in, and more coats of mud are daubed on until the walls attain a thickness of from four inches to a foot. Finally, the whole is roofed over with palm-branches and straw, the top being covered in with a thin layer of beaten earth. The height varies. In most huts, the ceiling is so low that to rise suddenly is dangerous both to one's head and to the structure, while in others the roof is six or seven feet from the floor. Windows, of course, there are none. Sometimes a hole is left in the middle of the roof to let the smoke out; but this is a refinement undreamed of by many.

* Near Feshun, on the opposite bank of the Nile ; called in Murray's Guide, El-Haybeh. 
At the first glance, it is not always easy to distinguish between these huts of wattle and daub and those built with crude bricks. The ordinary Egyptian brick is a mere oblong block of mud mixed with chopped straw and a little sand, and dried in the sun. At a spot where they are about to build, one man is told off to break up the ground; others carry the clods, and pile them in a heap, while others again mix them with water, knead the clay with their feet, and reduce it to a homogeneous paste. This paste, when sufficiently worked (Note 2), is pressed by the head workman
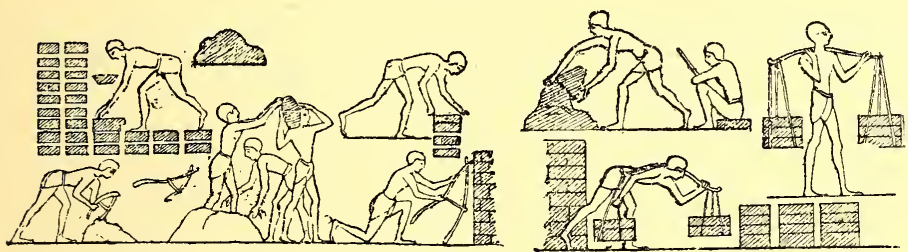

Fig. I.-Brickmaking.

in moulds made of hard wood, while an assistant carries away the bricks as fast as they are shaped, and lays them out in rows at a little distance apart, to dry in the sun (fig. I). A careful brickmaker will leave them thus for half a day, or even for a whole day; after which the bricks are piled in stacks in such wise that the air can circulate freely among them; and so they remain for a week or two before they are used. More frequently, however, they are exposed for only a few hours to the heat of the sun, and the building is begun while they are yet damp. The mud, however, is so tenacious that, notwithstanding this carelessness, they are not readily put out of shape. The outer 
faces of the bricks become disintegrated by the action of the weather, but those in the inner part of the wall remain intact, and are still separable. A good modern workman will easily mould a thousand bricks a day, and after a week's practice he may turn out I,200, I,500, or even $\mathrm{I}, 800$. The ancient workmen, whose appliances in no wise differed from those of the present day, produced equally satisfactory results. The dimensions they generally adopted were $8.7 \times 4.3 \times 5.5$ inches for ordinary bricks, or $\mathrm{I} 5^{\circ} \mathrm{O} \times 7^{\circ} \mathrm{I} \times 5^{\circ} 5$ for a larger size (Note 3 ), though both larger and smaller are often met with in the ruins. Bricks issued from the royal workshops were sometimes stamped with the cartouches of the reigning monarch; while those made by private factories bore on the side a trade mark in red ochre, a squeeze of the moulder's fingers, or the stamp of the maker. By far the greater number have, however, no distinctive mark. Burnt bricks were not often used before the Roman period (Note 4), nor tiles, either flat or curved. Glazed bricks appear to have been the fashion in the Delta. The finest specimen that I have seen, namely, one in the Boulak Museum, is inscribed in black ink with the cartouches of Rameses III. The glaze of this brick is green, but other fragments are coloured blue, red, yellow, or white.

The nature of the soil does not allow of deep foundations. It consists of a thin bed of made earth, which, except in large towns, never reaches any degree of thickness; below this comes a very dense humus, permeated by slender veins of sand; and below this again -at the level of infiltration-comes a bed of mud, more or less soft, according to the season. 'The native builders 
of the present day are content to remove only the made earth, and lay their foundations on the primeval soil; or, if that lies too deep, they stop at a yard or so below the surface. The old Egyptians did likewise; and I have never seen any ancient house of which the foundations were more than four feet deep. Even this is exceptional, the depth in most cases being not more than two feet. They very often did not trouble themselves to cut trenches at all; they merely levelled the space intended to be covered, and, having probably watered it to settle the soil, they at once laid the bricks upon the surface. When the house was finished, the scraps of mortar, the broken bricks, and all the accumulated refuse of the work, made a bed of eight inches or a foot in depth, and the base of the wall thus buried served instead of a foundation. When the new house rose on the ruins of an older one decayed by time or ruined by accident, the builders did not even take the trouble to raze the old walls to the ground. Levelling the surface of the ruins, they built upon them at a level a few feet higher than before: thus each town stands upon one or several artificial mounds, the tops of which not unfrequently rise to a height of from sixty to eighty feet above the surrounding country. The Greek historians attributed these artificial mounds to the wisdom of the kings, and especially to Sesostris, who, as they supposed, wished to raise the towns above the inundation. Some modern writers have even described the process, which they explain thus:-A cellular framework of brick walls, like a huge chess-board, formed the substructure, the cells being next filled in with earth, and the houses built upon this immense platform (Note 5). 
But where I have excavated, especially at Thebes, I have never found anything answering to this conception. The intersecting walls which one finds beneath the later houses are nothing but the ruins of older dwellings, which in turn rest on others still older. The slightness of the foundations did not prevent the builders from boldly running up quite lofty structures. In the ruins of Memphis, I have observed walls still standing from

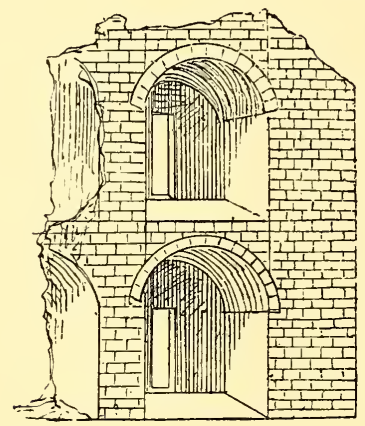

Fig. 2.--Ancient house with vaulted floors, against the northern wall of the great temple of Medinet-Haboo. thirty to forty feet in height. The builders took no precaution beyond enlarging the base of the wall, and vaulting the floors (fig. 2). The thickness of an ordinary wall was about sixteen inches for a low house; but for one of several storeys, it was increased to three or four feet. Large beams, embedded here and there in the brickwork or masonry, bound the whole together, and strengthened the structure. The ground floor was also frequently built with dressed stones, while the upper parts were of brick. The limestone of the neighbouring hills was the stone commonly used for such purposes. The fragments of sandstone, granite, and alabaster, which are often found mixed in with it, are generally from some ruined temple; the ancient Egyptians having pulled their neglected monuments to pieces quite as unscrupulously as do their modern successors.

The lower classes lived in mere huts which, though 
built of bricks, were no better than those of the present fellaheen. At Karnak, in the Pharaonic town; at Kom Ombo, in the Roman town; and at Medinet Haboo, in the Coptic town, the houses in the poorer quarters have seldom more than twelve or sixteen feet of frontage. They consist of a ground floor, with sometimes one or two living-rooms above. The middle class folk, as shopkeepers, sub-officials, and foremen, were better housed. Their dwellings were frequently separated from the street by a narrow court, beyond which the rooms were ranged on either side of a long passage (fig. 3). More fre-

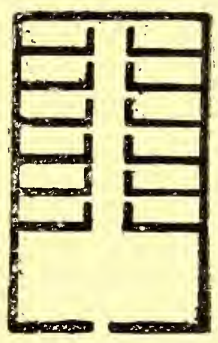

Fig. 3 . quently, the court was surrounded on three sides by chambers (fig. 4); and yet oftener, the house fronted close upon the street. In the latter case, the façade

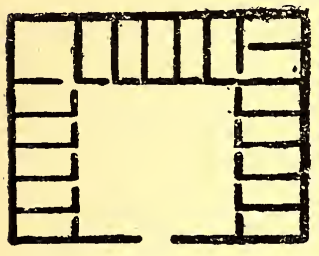

Fig. 4 . consisted of a high wall, whitewashed or painted, and surmounted by a cornice. The door was the only opening, save perhaps a few small windows pierced at irregular intervals (fig. 5). Even in unpretentious houses, the door was often made of stone. The doorposts projected slightly beyond the surface of the wall, and the lintel supported a painted or sculptured cornice. Having crossed the threshold, one passed successively through two dimly-lighted entrance chambers, the second of which opened into the central court (fig. 6); the ground-floor offices were used as 
stabling for donkeys or cattle, and as storerooms for grain and provisions, as well as for cellarage and kitchens. Wherever the upper floors still remain

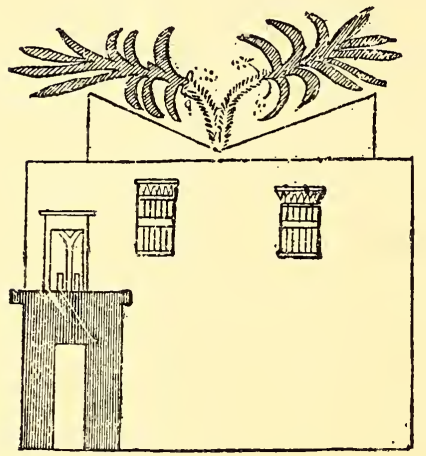

Fig. 5.--Façade of a house towards the street. standing, they reproduce the ground-floor plan with scarcely any differences. These upper rooms were reached by an outside staircase, steep and narrow and divided at short intervals by small square landings. The rooms were oblong, and were lighted only from the doorway; when it was decided to open windows on the street, they were mere air-holes near the ceiling, pierced without regularity or symmetry, fitted with a lattice of wooden cross bars, and secured by wooden shutters. The floors were bricked or paved, or consisted still more frequently of merely a layer of rammed earth. The walls were whitewashed, and occasionally painted with bright colours. The roof was flat, and made

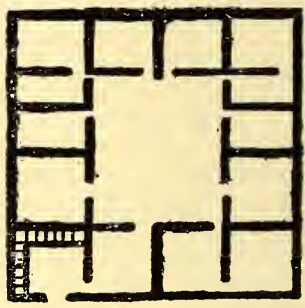

Fig. 6 . probably, as at the present day, of closely laid rows of palm-branches covered with a coating of mud thick enough to withstand the effects of rain. Sometimes it was surmounted by only one or two of the usual 
Egyptian ventilators; but generally there was a small washhouse on the roof, and a little chamber for the slaves or guards to sleep in. The terrace and the courtyard played an important part in the domestic life of the ancient Egyptians; it was there that the women gossiped, cooked, and made their bread (fig. 7). There, also, the whole family was wont to sleep in summer, under the shelter of mosquito nets.

The mansions of

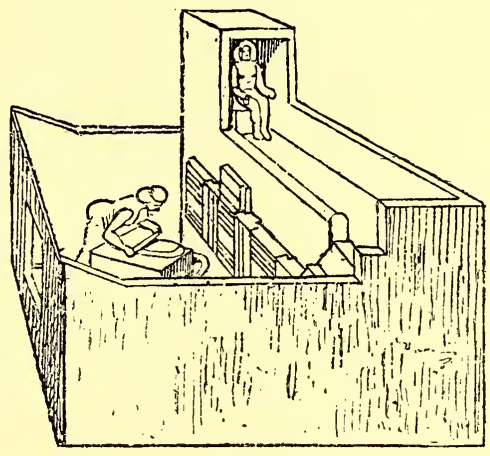

Fig. 7.-Box representing a house (British Museum). the rich and great covered a large space of ground. They most frequently stood in the midst of a garden, or of an enclosed court

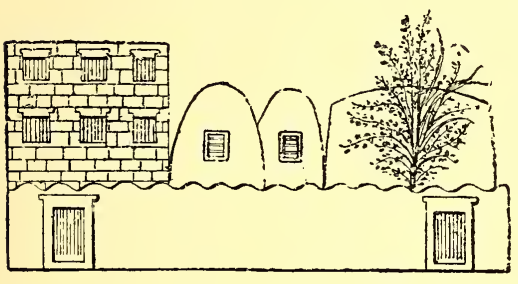

Fig. 8 . planted with trees; and, like the commoner houses, they turned a blank front to the street, consisting of bare walls battlemented like those of a fortress (fig. 8). Thus, home-life was strictly secluded, and the pleasure of seeing was sacrificed for the advantages of not being seen. The door was approached by a flight of two or three steps, or by a porch supported on columns (fig. 9) and adorned 
with statues (fig. IO), which gave it a monumental appearance, and indicated the social importance of the family. Sometimes this was preceded by a pylongateway, such as usually heralded the approach to a temple. Inside the enclosure it was like a small town, divided into quarters by irregular walls. The dwelling-house stood at the farther end.; the granaries, stabling, and open spaces being distributed in different parts of the grounds according to some system to which we as yet possess no clue. These arrangements, however, were infinitely varied. If I would convey some

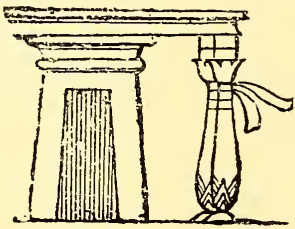

Fig. 9.

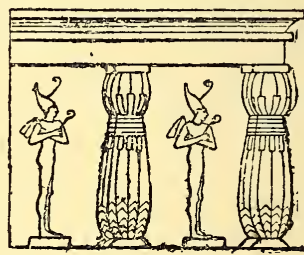

Fig. 10.

idea of the residence of an Egyptian noble,-a residence half palace, half villa,-I cannot do better than reproduce two out of the many pictorial plans which have come down to us among the tomb-paintings of the Eighteenth Dynasty. The first (figs. I I, I 2) represents a Theban house. The enclosure is square, and surrounded by an embattled wall. The main gate opens upon a road bordered with trees, which runs beside a canal, or perhaps an arm of the Nile. Low stone walls divide the garden into symmetrical compartments, like those which are seen to this day in the great gardens of Ekhmeem or Girgeh. In the centre 
is a large trellis supported on four rows of slender pillars. Four small ponds, two to the right and two to the left, are stocked with ducks and geese. Two

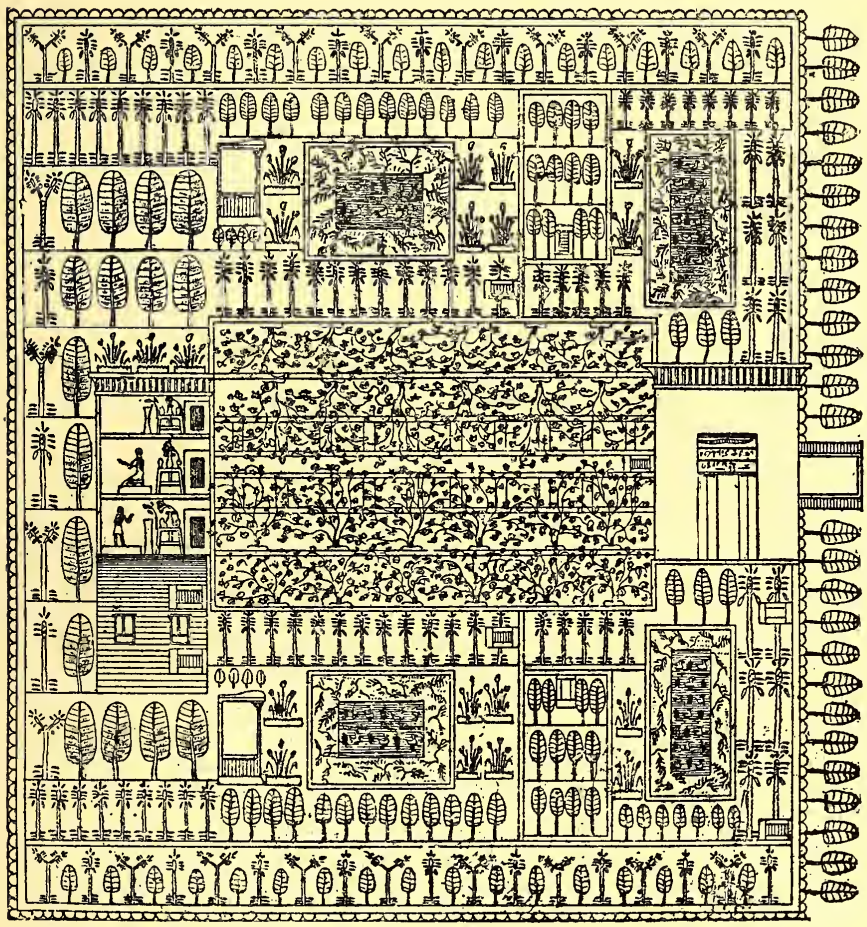

Fig. I I.-Plan of a Theban house with garden.

nurseries, two summer-houses, and various avenues of sycamores, date-palms, and Dom-palms fill up the intermediate space; while at the end, facing the entrance, stands a small two-storied house surmounted by a painted cornice. 
The second plan is copied from one of the rock-cut tombs of Tell el Arnarna (figs. I3, I4). Here we see a house situate at the end of the gardens of the great lord Aï, son-in-law of the Pharaoh Khou-en-Aten, and himself afterwards king of Egypt. An oblong stone tank with sloping sides, and two descending flights

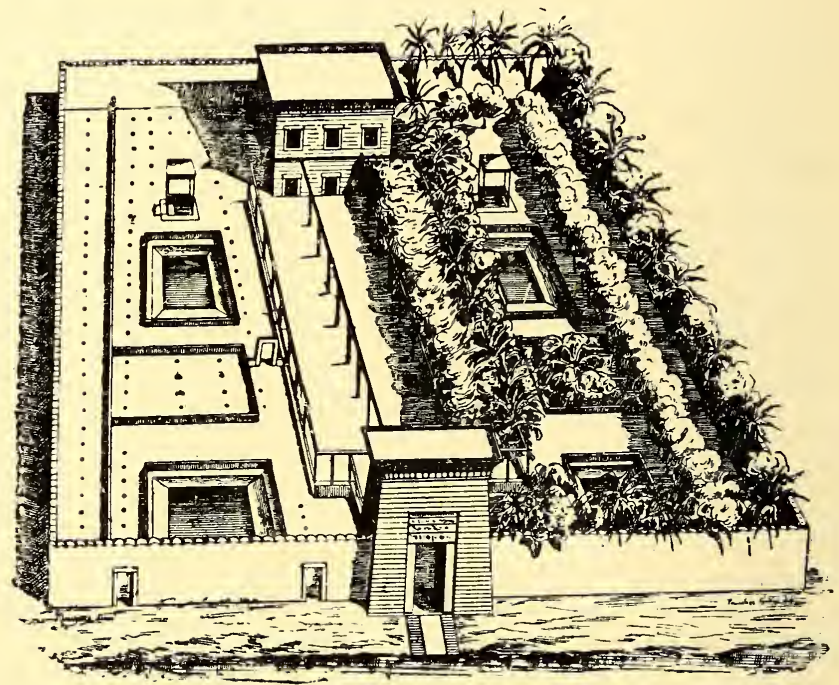

Fig. 12.-Perspective view of the Theban house.

of steps, faces the entrance. The building is rectangular, the width being somewhat greater than the depth. A large doorway opens in the middle of the front, and gives access to a court planted with trees and flanked by store-houses fully stocked with provisions. Two small courts, placed symmetrically in the two farthest corners, contain the staircases which 
lead up to the terrace. This first building, however, is but the frame which surrounds the owner's dwelling. The two frontages are each adorned with a pillared portico and a pylon. Passing the outer door, one enters a sort of long central passage, divided by two walls pierced with doorways, so as to form three successive courts. The inside court is bordered by chambers; the two others open to right and left upon two smaller courts, whence flights of steps lead up to the terraced roof. This central building is called the akhonuti, or private dwelling of kings or nobles, to which only the family and in-

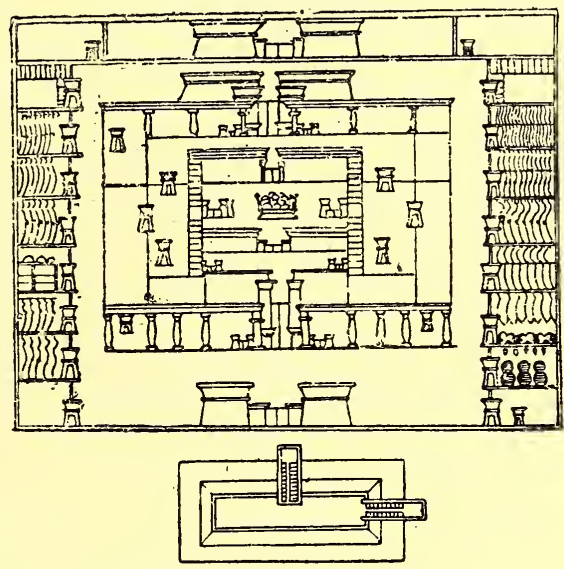

Fig. 13.-Palace of Aï. timate friends had access. The number of storeys and the arrangement of the façade varied according to the taste of the owner. The frontage was generally a straight wall. Sometimes it was divided into three parts, with the middle division projecting, in which case the two wings were ornamented with a colonnade to each story (fig. I 5), or surmounted by an open gallery (fig. I6). The central pavilion sometimes presents the appearance of a tower which dominates the 
rest of the building (fig. I 7 ). The façade is often decorated with slender colonnettes of painted wood, which bear no weight, and merely serve to lighten the somewhat severe aspect of the exterior. Of the internal arrangements, we know but little. As in the middle-class houses, the sleeping rooms were probably small and dark; but, on the other hand, the reception

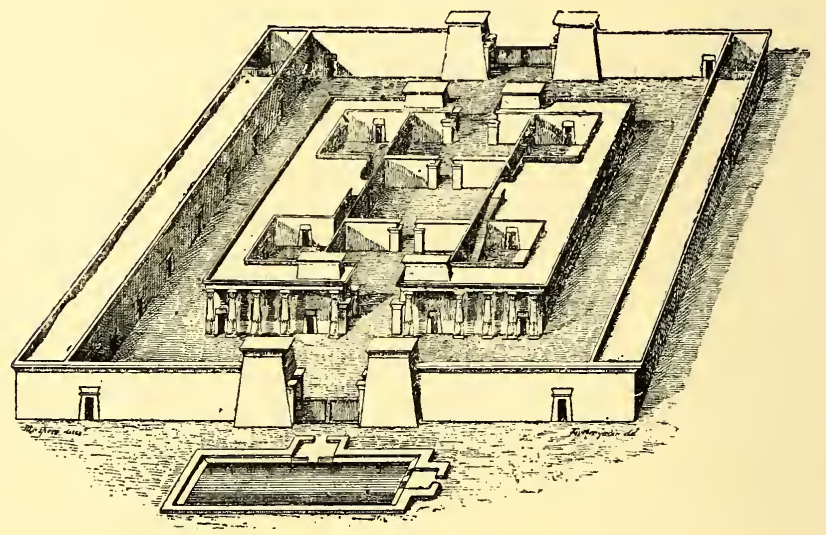

Fig. I4.-Perspective view of the Palace of Aï.

rooms must have been nearly as large as those still in use in the Arab houses of modern Egypt. The decoration of walls and ceilings in no wise resembled such scenes or designs as we find in the tombs. The panels were whitewashed or colourwashed, and bordered with a polychrome band. The ceilings were usually left white; sometimes, however, they were decorated with geometrical patterns, which repeated the leading motives employed in the sepulchral wall-paintings. Thus we find examples of meanders interspersed with rosettes 
(fig. I 8), parti-coloured squares (fig. I9), oxheads seen frontwise, scrolls, and flights of geese (fig. 20).

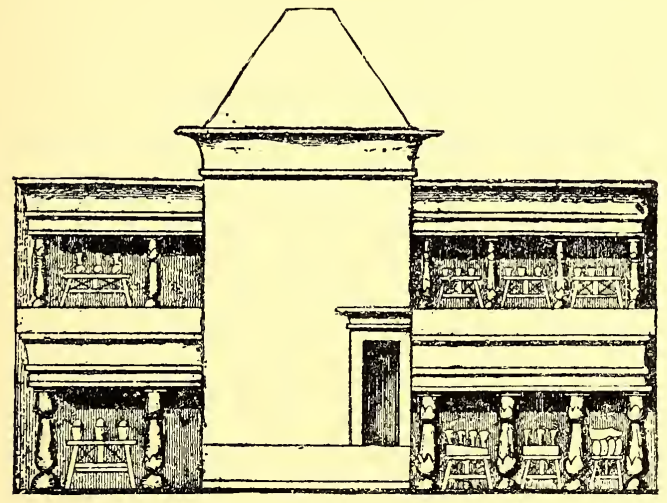

Fig. I5.

I have touched only upon houses of the second

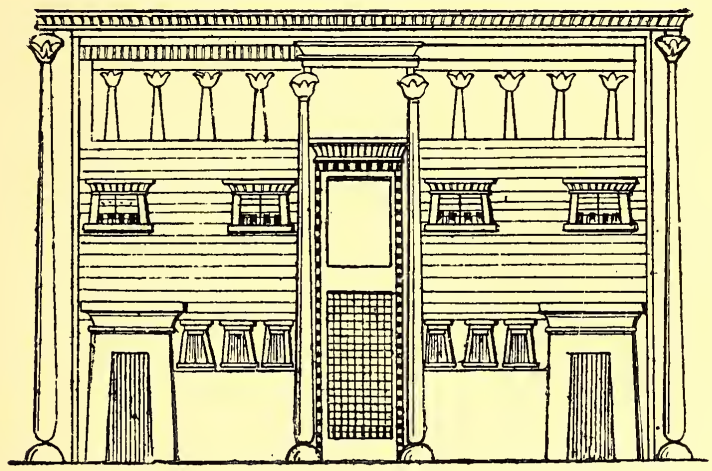

Fig. 16.

Theban period, this being in fact the time of which we have most examples. The house-shaped lamps which 
are found in such large numbers in the Fayoom date only from Roman times; but the Egyptians of that

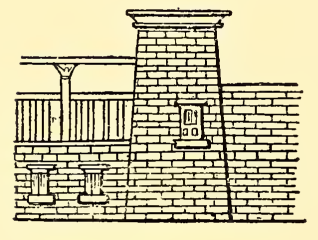

Fig. 17. period continued to build according to the rules which were in force under the Pharaohs of the Eighteenth, Nineteenth, and Twentieth Dynasties. As regards the domestic architecture of the ancient kingdom, the evidences are few and obscure. Nevertheless, the stelæ, tombs, and coffins of that period often furnish designs which show us the style of the doorways (fig. 2I), and one Fourth-Dynasty sarcophagus, that of Khufu-Poskhou, is carved in the likeness of a house (fig. 22).

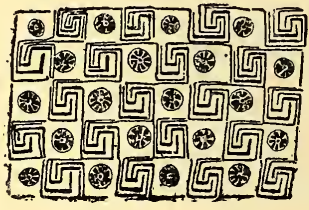

Fig. I8.

\section{II.-Fortresses.}

Most of the towns, and even most of the larger villages, of ancient Egypt were

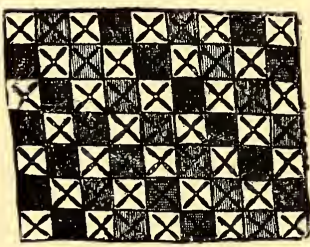

Fig. 19. walled. This was an almost necessary consequence of the geographical characteristics and the political constitution of the country. The mouths of the defiles which led into the desert needed to be closed against the Bedaween; while the great feudal nobles fortified their houses, their towns, and the villages upon their domains which commanded 
either the mountain passes or the narrow parts of the river, against their king or their neighbours.

The oldest fortresses are those of Abydos, El Kab, and Semneh. Abydos contained a sanctuary dedicated to Osiris, and was situate at the entrance to one of the roads leading to the Oasis. As the renown of the temple attracted pilgrims, so the position of the city caused it to be frequented by merchants; hence the prosperity which it derived from the influx of both classes of strangers exposed the city to incursions of the Libyan tribes. At Abydos there yet remain two almost perfect strongholds. The older forms, as it were, the core of that tumulus called by the Arabs

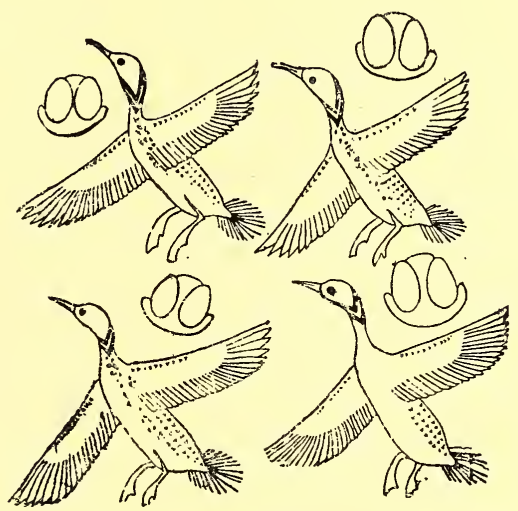

Fig. 20. "Kom-es-Sultan," or "the Mound of the King." The interior of this building has been excavated to a point some ten or twelve feet above the ground level, but the walls outside have not yet been cleared from the surrounding sand and rubbish. In its present condition, it forms a parallelogram of crude brickwork measuring $4 \mathrm{IO}$ feet from north to south, and 223 feet from east to west. The main axis of the structure extends, therefore, from north to south. The principal gateway opens in the western wall, 
not far from the north-west corner; but there would appear to have been two smaller gates, one in the south front, and one 556 in the east. The

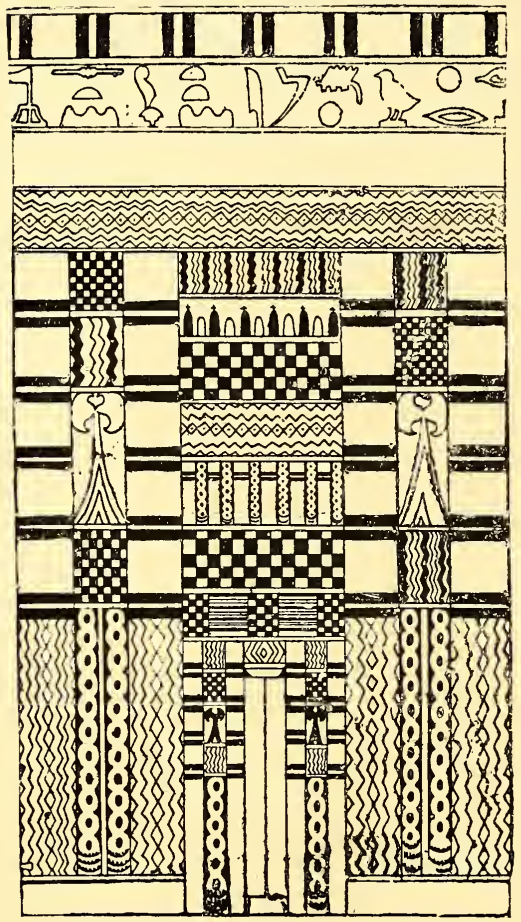
walls, which now stand from twentyfour to thirty-six feet high, have lost somewhat of their original height. They are about six feet thick at the top. They were not built all together in uniform layers, but in huge vertical panels, easily distinguished by the arrangement of the brickwork. In one division the bedding of the bricks is strictly horizontal; in the next it is slightly concave, and forms a very Fig. 21.-Door of a house of the Ancient flat reversed arch, Empire, from the wall of a tomb of the of which the exSixth Dynasty.

trados rests upon the ground. The alternation of these two methods is regularly repeated. The object of this arrangement is obscure; but it is said that buildings thus con- 
structed are especially fitted to resist earthquake shocks. However this may be, the fortress is extremely ancient, for ever since the Fifth Dynasty, the nobles of Abydos took possession of the interior, and so piled it up with their graves as to deprive it of all strategic value. A second stronghold, erected a few hundred yards further to the south-east, replaced that of Kom-esSultan somewhere about the time of the Eighteenth Dynasty, and narrowly escaped the fate of the first, under the rule of the Ramessides. Nothing, in fact, but

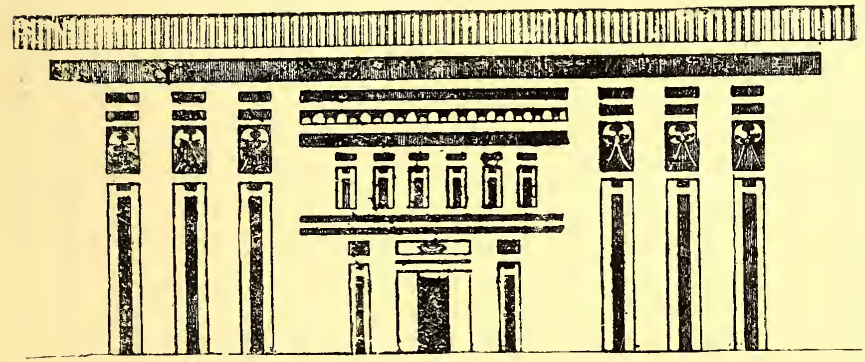

Fig. 22.

the sudden decline of the city, saved it from being similarly choked and buried.

The early Egyptians possessed no engines calculated to make an impression on very massive walls. They knew of but three ways of forcing a stronghold ; namely, scaling the walls, sapping them, or bursting open the gates. The plan adopted by their engineers in building the second fort is admirably well calculated to resist each of these modes of attack (fig. 23). The outer walls are long and straight, without towers or projections of any kind; they measure 430 feet in length from north to 
south, by 255 feet in width. The foundations rest on the sand, and do not go down more than a foot. The wall (fig. 24) is of crude brick, in horizontal courses. It has a slight batter; is solid, without slits or loopholes ; and is decorated outside with long vertical grooves or panels, like those depicted on the stelæ of the ancient empire. In its present state, it rises to a height of some thirty-six feet above the plain; when

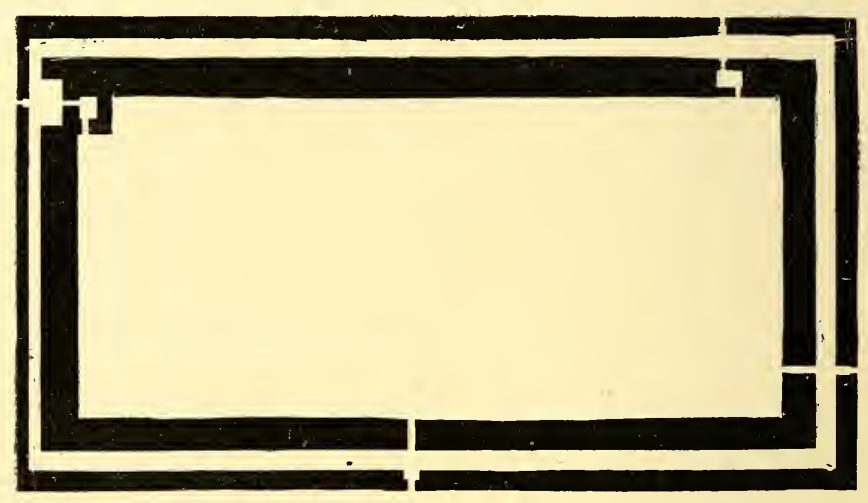

Fig. 23.

perfect, it would scarcely have exceeded forty feet, which height would amply suffice to protect the garrison from all danger of scaling by portable ladders. The thickness of the wall is about twenty feet at the base, and sixteen feet above. The top is destroyed, but the basreliefs and mural paintings (fig. 25) show that it must have been crowned with a continuous cornice, boldly projecting, furnished with a slight low parapet, and surmounted by battlements, which were generally rounded, but sometimes, though rarely, squared. The 
walk round the top of the ramparts, though diminished by the parapet, was still twelve or fifteen feet wide. It ran uninterruptedly along the four sides, and was reached by narrow staircases formed in the thickness of the walls, but now destroyed. There was no ditch, but in order to protect the base of the main wall from sappers, they erected, about ten feet in advance of it, a battlemented covering wall, some sixteen feet in height. These precautions sufficed against sap and scaling; but the gates remained as open gaps

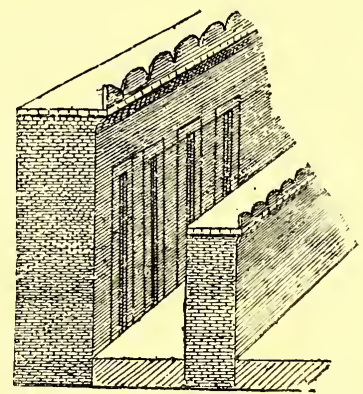

Fig. 24. in the circuit. It was upon these weak points that besiegers and besieged alike concentrated their efforts.

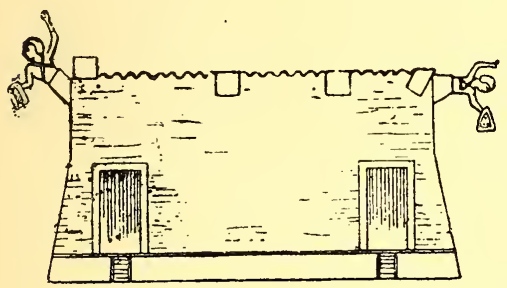

Fig. 25 . The fortress of Abydos had two gates, the main one being situate at the east end of the north front (fig. 26). A narrow cutting (A), closed by a massive wooden door, marked the place in the covering wall. Behind it was a small place d'armes (B), cut partly in the thickness of the wall, and leading to a second gate (c) as narrow as the first. When, notwithstanding the showers of missiles poured upon them from the top of the walls, not only in front, but also from both sides, the attacking party had suc- 
ceeded in carrying this second door, they were not yet in the heart of the place. They would still have to traverse an oblong court (D), closely hemmed in between the outer walls and the cross

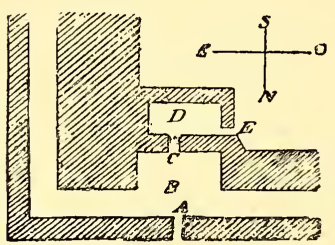

Fig. 26. walls, which last stood at right angles to the first. Finally, they must force a last postern (E), which was purposely placed in the most awkward corner. The leading principle in the construction of fortressgates was always the same, but the details varied according to the taste of the engineer. At the southeast gate of the fort of Abydos (fig. 27) the place d'armes between the two walls is abolished, and the court is constructed entirely in the thickness of the main wall; while at Kom-el-Ahmar, opposite $\mathrm{El} \mathrm{Kab}$ (fig. 28), the block of brickwork in

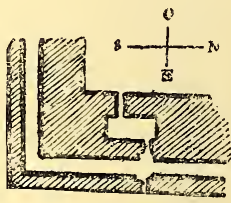

Fig. 27. the midst of which the gate is cut projects boldly in front. The posterns opening at various points facili-

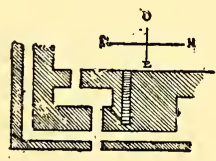

Fig. 28. tated the movements of the garrison, and enabled them to multiply their sorties.

The same system of fortification which was in use for isolated fortresses was also employed for the protection of towns. At Heliopolis, at Sān, at Sais, at Thebes, everywhere in short, we find long straight walls forming plain squares or parallelograms, without towers or bastions, ditches or outworks. The thickness 
of the walls, which varied from thirty to eighty feet, made such precautions needless. The gates, or at all events the principal ones, had jambs and lintels of stone, decorated with scenes and inscriptions ; as, for instance, that of Ombos, which Champollion beheld yet in situ, and which dated from the reign of Thothmes III. The oldest and best preserved walled city in Egypt, namely, El Kab, belongs probably to the ancient empire (fig. 29). The Nile washed part of it away some years ago; but at the beginning of the present century it formed an irregular quadrilateral enclosure, measuring some 2, 100 feet in length, by about a quarter less in breadth. The south front is constructed on the

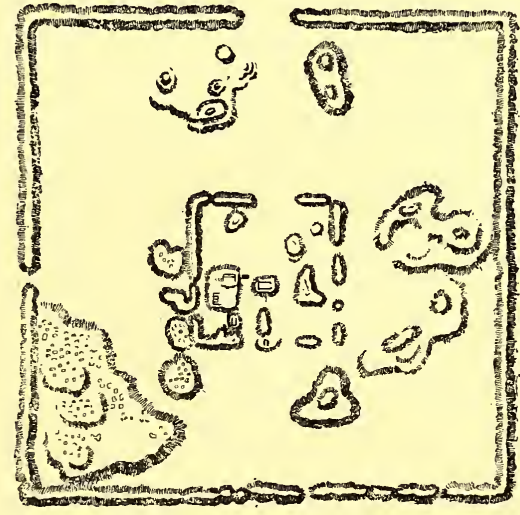

Fig. 29. same principles as the wall at Kom-es-Sultan, the bricks being bedded in alternate horizontal and concave sections. Along the north and west fronts they are laid in undulating layers from end to end. The thickness is thirty-eight feet, and the average height thirty feet; and spacious ramps lead up to the walk upon the walls. The gates are placed irregularly, one in each side to north, east, and west, but none in the south face; they are, however, in too ruinous a state to admit of any plan being taken of them. The 
enclosure contained a considerable population, whose dwellings were unequally distributed, the greater part being concentrated towards the north and west, where excavations have disclosed the remains of a large number of houses. The temples were grouped together in a square enclosure, concentric with the outer wall; and this second enclosure served for a keep, where the garrison could hold out long after the rest of the town had fallen into the hands of the enemy.

The rectangular plan, though excellent in a plain, was

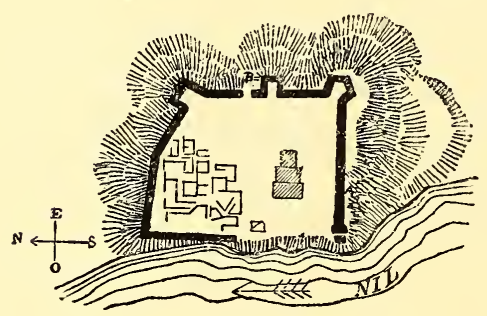

Fig. 30 . not always available in a hilly country. When the spot to be fortified was situate upon a height, the Egyptian engineers knew perfectly well how to adapt their lines of defence to the nature of the site.

At Kom Ombo (fig. 30) the walls exactly followed the outline of the isolated mound on which the town was perched, and presented towards the east a front bristling with irregular projections, the style of which roughly resembles our modern bastions. At Kummeh and Semneh, in Nubia, where the Nile rushes over the rocks of the second cataract, the engineering arrangements are very ingenious, and display much real skill. Usertesen III. had fixed on this pass as the frontier of Egypt, and the fortresses which he there constructed were intended to bar the water-way against the vessels of the neighbouring negro tribes. At Kummeh, on the 
right bank, the position was naturally strong (fig. 3I). Upon a rocky height surrounded by precipices, was planned an irregular square measuring about 200 feet each way. Two elongated bastions, one on the north-east and the other on the southeast, guarded respectively the path leading to the gate, and the course of the river.

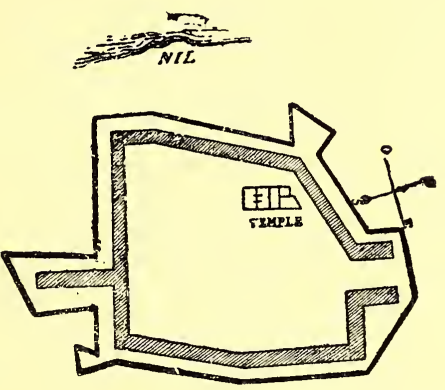

Fig. 3I.

The covering wall stood thirteen feet high, and closely followed the line of the main wall, except at the north

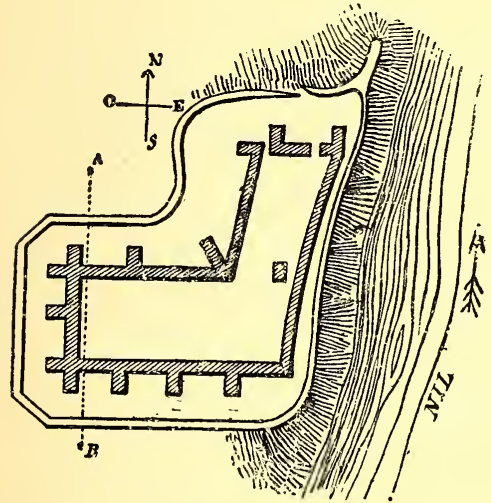

Fig. 32 . and south corners, where it formed two bastion-like projections. At Semneh, on the opposite bank, the site was less favourable. The east side was protected by a belt of cliffs going sheer down to the water's edge; but the three other sides were well-nigh open (fig. 32). A straight wall, about fifty feet in height, was carried along the cliffs on the side next the river; but the walls looking towards the plain rose to eighty feet, and bristled 
with bastion-like projections jutting out for a distance of fifty feet from the curtain wall, measuring thirty feet thick at the base and thirteen feet at the top, and irregularly spaced, according to the requirements of the defence. These spurs, which are not battlemented, served in place of towers. They added to the strength of the walls, protected the walk round the top, and enabled the besieged to direct a flank attack against the enemy if any attempt were made upon the wall of circuit. The intervals between these spurs are accurately calculated as to distance, in order that the archers should be able to

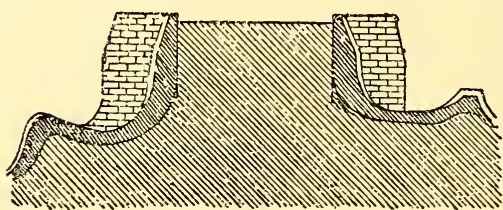

Fig. 33. - Section of the platform at A B, of the preceding plan. sweep the intervening ground with their arrows. Curtains and salients are alike built of crude brick, with beams bedded horizontally in the mass. The outer face is in two parts, the lower division being nearly vertical, and the upper one inclined at an angle of about seventy degrees, which made scaling very difficult, if not impossible. The whole of the ground enclosed by the wall of circuit was filled in to nearly the level of the ramparts (fig. 33). Externally, the covering wall of stone was separated from the body of the fortress by a dry ditch, some IOO to I 30 feet in width. This wall closely followed the main outline, and rose to a height which varied according to the situation from six to ten feet above the level of the plain. On the northward side it was cut by the winding road, which led down into the plain. These 
arrangements, skilful as they were, did not prevent the fall of the place. A large breach in the southward face, between the two salients nearest to the river, marks the point of attack selected by the enemy.

New methods of fortification were revealed to the Egyptians in the course of the great Asiatic wars undertaken by the Pharaohs of the Eighteenth Dynasty. The nomadic tribes of Syria erected

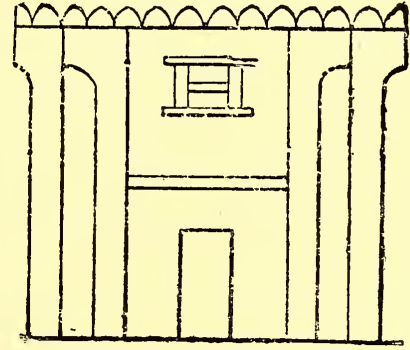

Fig. 34 . small forts in which they took refuge when threatened with invasion (fig. 34). The Canaanite and Hittite

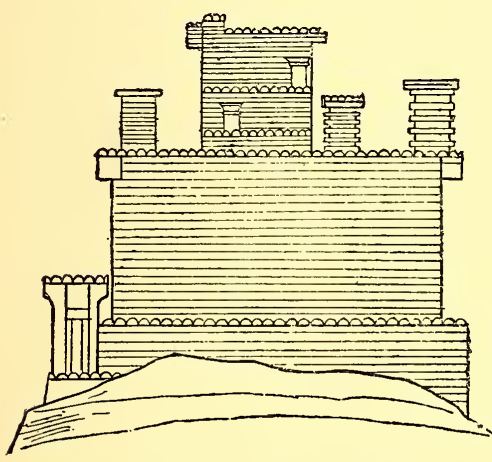

Fig. 35.-The town of Dapour. cities, as Ascalon, Dapour, and Merom, were surrounded by strong walls, generally built of stone and flanked with towers (fig. 35). Those which stood in the open country, as for instance Qodshou (Kadesh), were enclosed by a double moat (fig. 36). Having proved the efficacy of these new types of defensive architecture in the course of their campaigns, the Pharaohs reproduced them in the valley of the Nile. From the beginning of the Nineteenth Dynasty, the eastern frontier of the Delta (always the 
weakest) was protected by a line of forts constructed after the Canaanite model. The Egyptians, moreover, not content with appropriating the thing, appropriated also the name, and called these frontier towers by the

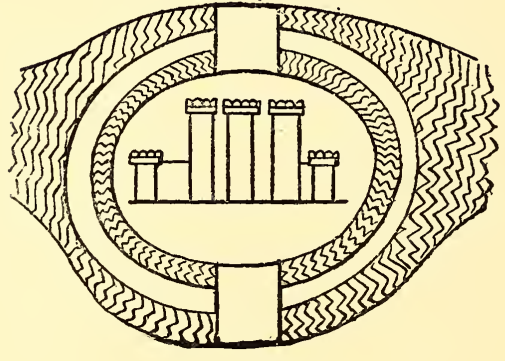

Fig. 36.

Semitic name of Magdilu, or Migdols.* For these purposes, or at all events for cities which were exposed to the incursions of the Asiatic tribes, brick was not deemed to be sufficiently strong; hence the walls of Heliopolis, and even those of Memphis, were faced with storie. Of these new fortresses no ruins remain; and but for a royal caprice which happens to have left us a model Migdol in that most unlikely place, the necropolis of Thebes, we should now be constrained to attempt a restoration of their probable appearance from the representations in certain mural tableaux. When, however, Rameses III. erected his
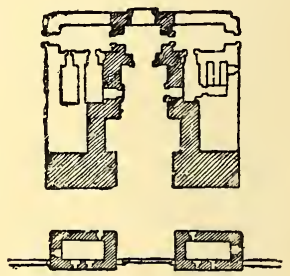

Fig. 37.-Plan of the pavilion of Medinet Haboo. memorial temple $\uparrow$ (figs. 37 and 38), he desired, in remembrance of his Syrian victories, to give it an outwardly military aspect. Along the eastward front of the enclosure there accordingly runs a battlemented

* In Egyptian, "Makatilu,"

$\dagger$ At Medinet Haboot. 
covering wall of stone, averaging some thirteen feet in height. The gate, protected by a large quadrangular bastion, opened in the middle of this wall. It was three feet four inches in width, and was flanked by two small oblong guard-houses, the flat roofs of which stood about three feet higher than the ramparts. Passing this gate, one stands face to face with a real Migdol. Two blocks of building enclose a succession of courtyards, which narrow as they recede, and are connected

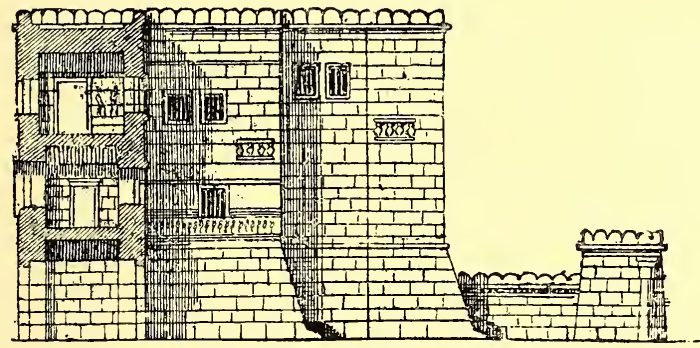

Fig. 38 .

at the lower end by a kind of gate-house, consisting of one massive gateway surmounted by two storeys of chambers. The eastward faces of the towers rise above an inclined basement, which slopes to a height of from fifteen to sixteen feet from the ground. This answered two purposes. It increased the strength of the wall at the part exposed to sappers; it also caused the rebound of projectiles thrown from above, and so helped to keep assailants at a distance. The whole height is about seventy-two feet, and the frontwise width of each tower is thirty-two feet. The buildings situate at the back, to right and left of the gate, were destroyed in ancient times. The details of the decora- 
tion are partly religious, partly triumphal, as befits the character of the structure. It is unlikely, however, that actual fortresses were adorned with brackets and basrelief sculptures, such we here see on either side of the fore-court. Such as it is, the so-called "pavilion" of Medinet Haboo offers an unique example of the high degree of perfection to which the victorious Pharaohs of this period had carried their military architecture.

Material evidence fails us almost entirely, after the reign of Rameses III. Towards the close of the eleventh century B.c., the high-priests of Amen repaired the walls of Thebes, of Gebelayn, and of $\mathrm{El}$ Hibéh opposite Feshun. The territorial subdivision of the country, which took place under the successors of Sheshonk, compelled the provincial princes to multiply their strongholds. The campaign of Piankhi on the banks of the Nile is a series of successful sieges. Nothing, however, leads us to suppose that the art of fortification had at that time made any distinct progress; and when the Greek rulers succeeded the native Pharaohs, they most probably found it in much the same stage that it was left by the engineers of the Nineteenth and Twentieth Dynasties.

\section{III.-Public Works.}

A permanent network of roads would be useless in a country like Egypt. The Nile here is the natural highway for purposes of commerce, and the pathways which intersect the fields suffice for foot-passengers, for cattle, and for the transport of goods from village to village. Ferry-boats for crossing the river, fords wherever the canals were shallow enough, and em- 
banked dams thrown up here and there where the water was too deep for fordings, completed the system of internal communication. Bridges were rare. Up to the present time, we know of but one in the whole territory of ancient Egypt; and whether that one was long or short, built of stone or of wood, supported on arches or boldly flung across the stream from bank to bank, we cannot even conjecture. This bridge, close under the very walls of Zaru, ${ }^{*}$ crossed the canal which separated the eastern frontier of Egypt from the desert regions of Arabia Petræa. A fortified enclosure protected this canal on the Asiatic side, as shown in the accompanying illustration (fig. 39). The maintenance of public highways, which figures as so costly an item in the expenses of modern nations, played, therefore, but a very small part in the annual disbursements of

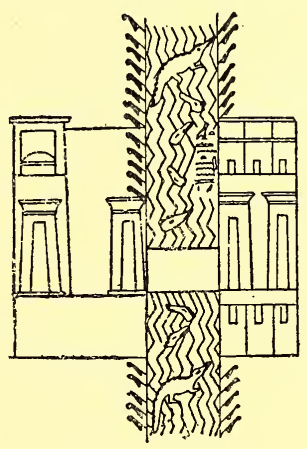

Fig. 39. the Pharaohs, who had only to provide for the due execution of three great branches of government works, -namely storage, irrigation, mining and quarrying.

The taxation of ancient Egypt was levied in kind, and government servants were paid after the same

* The bas-relief sculpture from which the above illustration is taken (outer wall of Hypostyle Hall, Karnak, north end) represents Seti I. returning in triumph from one of his Syrian campaigns. He is met at Zaru by the great officers of his court, who bring bouquets of lotus-blossoms in their hands. Pithom and other frontier forts are depicted in this tableau, and Pithom is apparently not very far from Zaru. The site of Zaru has not yet been identified. [Translator's note.] 
system. To workmen, there were monthly distributions of corn, oil, and wine, wherewith to support their families; while from end to end of the social scale, each functionary, in exchange for his labour, received cattle, stuffs, manufactured goods, and certain quantities

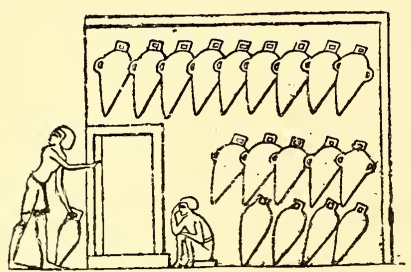

Fig. 40.

of copper or precious metals. Thus it became necessary that the treasury officials should have the command of vast storehouses for the safe keeping of the various goods collected under the head of taxation. These were classified and stored in separate quarters, each storehouse being surrounded by walls and guarded by vigilant keepers. There was enormous stabling for cattle; there were cellars where the amphoræ were piled in regular layers (fig. 40), or hung in rows upon the walls, each with the date

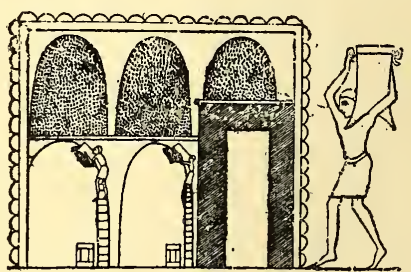

Fig. 4I. written on the side of the jar; there were oven-shaped granaries where the corn was poured in through a trap at the top (fig. 4I), and taken out through a trap at the bottom. At Thuku, identified with Pithom by M. Naville, * the storechambers (A) are rectangular and

* See "The Store City of Pithom and the Route of the Exodus," by Ed. Naville, with I3 Plates and 2 Maps; published by the Egypt Exploration Fund. First edition 1885, second edition I885. Trübner \& Co., London. [Translator's note.] 
of different dimensions (fig. 42), originally divided by floors, and having no communication with each other. Here the corn had to be not only put in but taken out through the aperture at the top. At the Ramesseum, Thebes, thousands of ostraka and jar-stoppers found upon the spot prove that the brick-built remains at the back of the temple were the cellars of the local deity. 'The ruins consist of a series of vaulted chambers originally surmounted by a platform or terrace (fig. 43). At Philæ, Ombos,

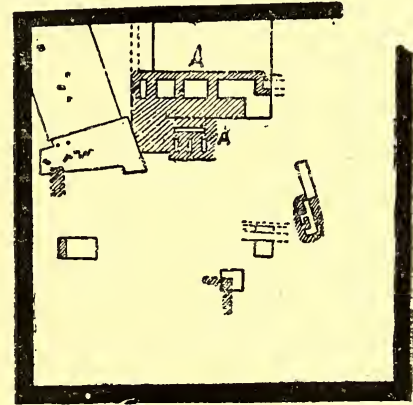

Fig. 42 .

Daphnæ,* and most of the frontier towns of the Delta, there were magazines of this description, and many

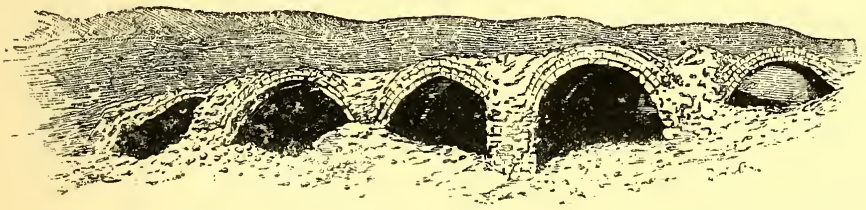

Fig. 43.

more will doubtless be discovered when made the object of serious exploration.

* For an account of the recent explorations at Daphnæ (the "Tahpanhes" of the Bible, the Tell Defenneh of the present day) see Mr. Petrie's memoir, entitled "Tanis, Part II. (including Nebesheh, Gemayemi, Defenneh, etc.)," shortly to be published by the Egypt Exploration Fund. [Translator's note.] 
The irrigation system of Egypt is but little changed since the olden time. Some new canals have been cut, and yet more have been silted up through the negligence of those in power; but the general scheme, and the methods employed, continue much the same, and demand but little engineering skill. Wherever I have investigated the remains of ancient canals, I have been unable to detect any traces of masonry at the weak points, or at the mouths, of these cuttings. They are mere excavated ditches, from twenty to sixty or seventy feet in width. The earth flung out during the work was thrown to right and left, forming irregular embankments from seven to fourteen feet in height. The course of the ancient canals was generally straight; but that rule was not strictly observed, and enormous curves were often described in order to avoid even slight irregularities of surface. Dikes thrown up from the foot of the cliffs to the banks of the Nile, divided the plain at intervals into a series of artificial basins where the overflow formed back-waters at the time of inundation. These dikes are generally earthworks, though they are sometimes constructed of baked brick, as in the province of Girgeh. Very rarely are they built of hewn stone, like that great dike of Kosheish which was constructed by Mena in primæval times, in order to divert the course of the Nile from the spot on which he founded Memphis. ${ }^{*}$ The network of canals began near Silsilis and extended to the seaboard, without ever losing touch of the river, save at

* The remains of this gigantic work may yet be seen about two hours' distance to the southward of Meydoom. See Herodotus, book ii., chap. 99. [Translator's note.] 
one spot near Beni-Souef, where it throws out a branch in the direction of the Fayoom. Here, through a narrow and sinuous gorge, deepened probably by the hand of man, it passes the rocky barrier which divides that low-lying province from the valley of the Nile, and thence expands into a fanlike ramification of innumerable channels. Having thus irrigated the district, the waters flow out again; those nearest the Nile returning by the same way that they flowed in, while the rest form a series of lakes, the largest of which is known as the Birket-el-Korn. If we are to believe Herodotus, the work was not so simply done. A king, named Mœris, desired to create a reservoir in the Fayoom which should neutralise the evil effects of insufficient or superabundant inundations. This reservoir was named, after him, Lake Mœris. If the supply fell below the average, then the stored waters were let loose, and Lower Egypt and the Western Delta were flooded to the needful height. If next year the inundation came down in too great force, Lake Mœris received and stored the surplus till such time as the waters began to subside. Two pyramids, each surmounted by a sitting colossus, one representing the king and the other his queen, were erected in the midst of the lake. Such is the tale told by Herodotus, and it is a tale which has considerably embarrassed our modern engineers and topographers. How, in fact, was it possible to find in the Fayoom a site which could have contained a basin measuring at least ninety miles in circumference? The most reasonable theory is that of Linant, who supposes Lake Mœris to have extended over the whole of the lowlying land which 
skirts the Libyan cliffs between Illahoun and Medinet el-Fayoom ; but recent explorations have proved that the dikes by which this pretended reservoir was bounded are modern works, erected probably within the last two hundred years. I no longer believe that Lake Mœris ever existed. If Herodotus did actually visit the Fayoom, it was probably in summer, at the time of the high Nile, when the whole district

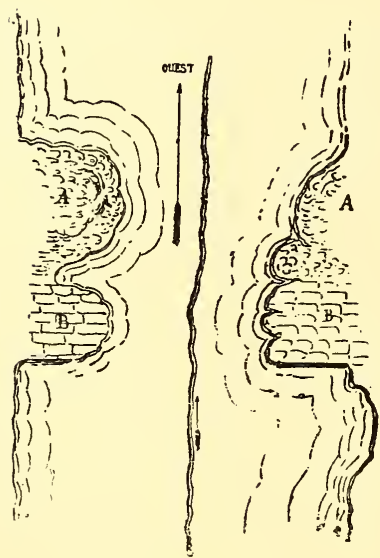

Fig. 44. presents the appearance of an inland sea. What he took for the shores of this lake were the embankments which divided it into basins and acted as highways between the various towns. His narrative, repeated by the classic authors, has been accepted by the moderns; and Egypt, neither accepting nor rejecting it, was gratified long after date with the reputation of a gigantic work which would in truth have been the glory of her civil engineers, if it had ever existed.* The only works of the kind which they did undertake were much less pretentious. These consist of stone-built dams erected at the mouths of

* The French idiom here is almost untranslatable; I, therefore, give the original :- "Son récit, repété par les écrivains anciens, a été accepté par nos contemporains, et l'Egypte, qui n'en pouvait mais, a été gratifiée après coup d'une œuvre gigantesque, dont l'exécution aurait été le vrai titre de gloire des ses ingénieurs, si elle avait jamais existé." [Translator's note.] 
many of those lateral ravines, or wadys, which lead down from the mountain ranges into the valley of the Nile. One of the most important among them was pointed out, in I 885 , by Dr. Schweinfurth, at a distance of about six miles and a half from the Baths of Helwán, at the mouth of the Wady Gerraweh (fig.44). It answered two purposes, firstly, as a means of storing the water of the inundation for the use of the workmen in the neighbouring quarries; and, secondly, as a barrier to break the force of the torrents which rush down from the desert after the heavy rains of springtime and winter. The ravine measures about 240 feet in width, the sides being on an average from 40 to 50 feet in height. The dam, which is 143 feet in thickness, consists of three layers of material; at the bottom (A), a bed of clay and

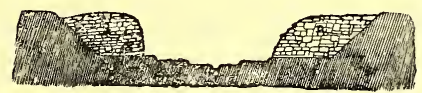

Fig. 45 . rubble; next, a piled mass of limestone blocks ; lastly, a wall of cut stone built in retreating stages, like an enormous flight of steps. Thirty-two of the original thirty-five stages are yet in situ, and about one-fourth part of the dam remains piled up against the sides of the ravine to right and left; but the middle part has been swept away by the force of the torrent (fig. 45). A similar dyke transformed the end of Wady Genneh into a little lake which supplied the Sinaitic miners with water.

Most of the localities from which the Egyptians derived their metals and choicest materials in hard stone, were difficult of access, and would have been useless had roads not been made, and works of this 
kind carried out, so to make life somewhat less insupportable when there.

In order to reach the diorite and grey granite quarries of the Hammamat Valley, the Pharaohs caused a series of rock-cut cisterns to be constructed along the line of route. Some few insignificant springs, skilfully conducted into these reservoirs, made it possible to plant workmen's villages in the neighbourhood of the quarries, and also near the emerald mines on the borders of the Red Sea. Hundreds of hired labourers, slaves, and condemned criminals here led a wretched existence under the rule of some eight or ten overseers, and the brutal surveillance of a company of Libyan or negro mercenary troops. The least political disturbance in Egypt, an unsuccessful campaign, or any untoward incident of a troubled reign, sufficed to break up the precarious stability of these remote establishments. The Bedaween at once attacked the colony; the workmen deserted; the guards, weary of exile, hastened back to the valley of the Nile, and all was at a standstill.

The choicest materials, as diorite, basalt, black granite, porphyry, and red and yellow breccia, which are only found in the desert, were rarely used for architectural purposes. In order to procure them, it was necessary to organise regular expeditions of soldiers and workmen; therefore they were reserved for sarcophagi and important works of art. Those quarries which supplied building materials for temples and funereal monuments, such as limestone, sandstone, alabaster, and red granite, were all tound in the Nile valley, and were, therefore, easy of access. When the 
vein which it was intended to work traversed the lower strata of the rock, the miners excavated chambers and passages, which were often prolonged to a considerable distance. Square pillars, left standing at intervals, supported the superincumbent mass, while tablets sculptured in the most conspicuous places commemorated the kings and engineers who began or continued the work. Several exhausted or abandoned quarries have been transformed into votive chapels; as, for instance, the Speos Artemidos, which was consecrated by Thothmes III. and Seti I. to the local goddess Pakht.*

The most important limestone quarries are at Toorah and Massarah, nearly opposite Memphis. This stone lends itself admirably to the most delicate touches of the chisel, hardens when exposed to the air, and acquires a creamy tone most restful to the eye. Hence it was much in request by architects and sculptors. The most extensive sandstone formations are at Silsilis (fig. 46). Here the cliffs were quarried from above, and under the open sky. Clean cut and absolutely vertical, they rise to a height of from forty to fifty feet, sometimes presenting a smooth surface from top to bottom, and sometimes cut in stages accessible by means of steps searcely large enough for one man at a time. The walls of these cuttings are covered with parallel striæ, sometimes horizontal, sometimes slanting to the left, and sometimes to the right, so forming lines of serried chevrons framed, as it were, between grooves an inch,

* M. Golenischeff, in an important article contributed to the Recueil des Travaux, vol. iii., has shown that this Speos was in all probability consecrated by Queen Hatshepsu, whose cartouches were afterwards erased by Thothmes III. in favour of his own. [Translator's note.] 
or an inch and a half, in width, by nine or ten feet in length. These are the scars left upon the surface by

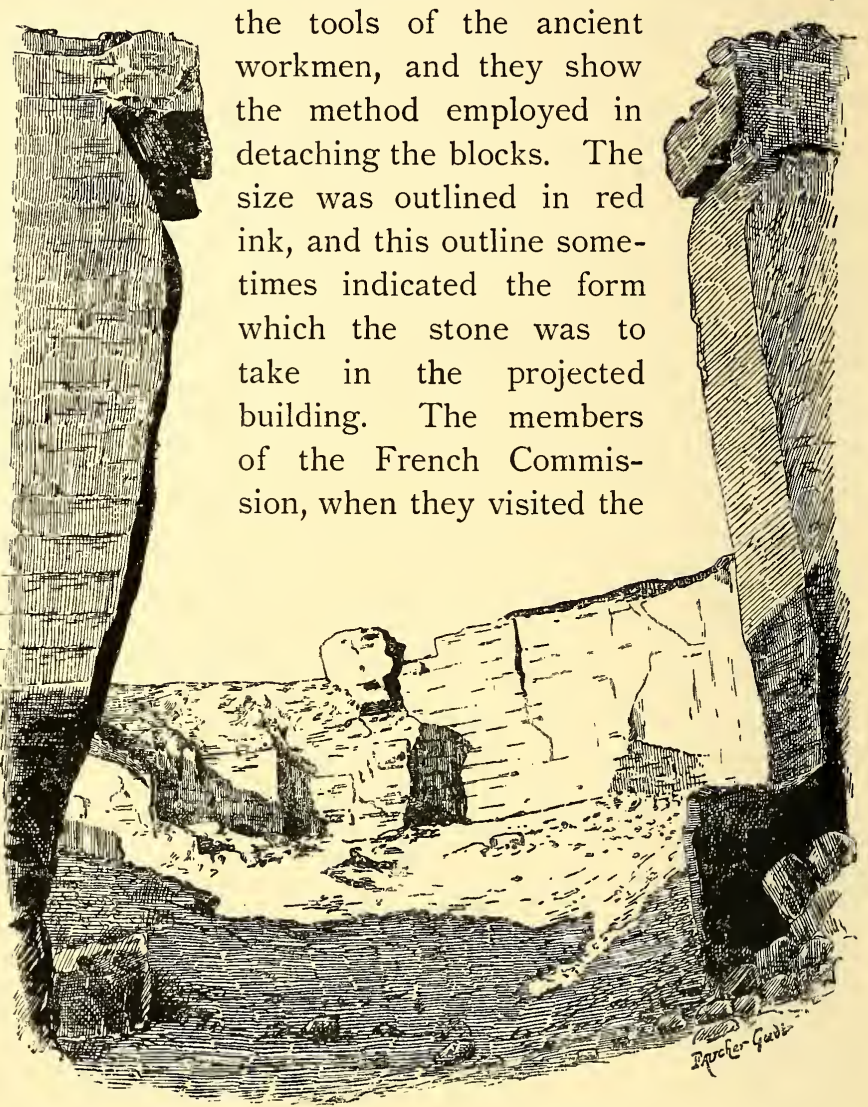

Fig. 46 .

quarries of Gebel Aboofaydah, copied the diagrams and squared designs of several capitals, one being of the lotus pattern, and others prepared for the Hathor- 
headed pattern (fig. 47). The outline made, the vertical faces of the block were divided by means of a long iron chisel, which was driven in perpendicularly or obliquely by heavy blows of the mallet. In order to detach the horizontal faces, they made use of wooden or iron wedges, inserted the way of the natural strata of the stone. Very frequently the stone was roughly

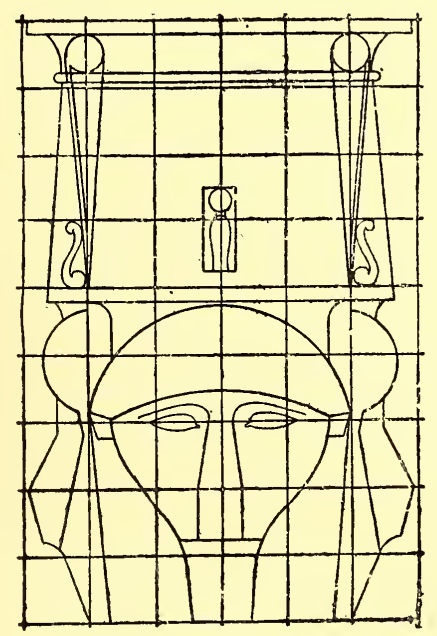

Fig. 47 .

blocked out before being actually extracted from the bed. Thus at Syene (Assouan) we see a couchant obelisk of granite, the under side of which is one with the rock itself; and at Tehneh there are drums of columns but half disengaged. The transport of quarried stone was effected in various ways. At Syene, at Silsilis, at Gebel Sheykh Heréedeh, and at Gebel Aboofaydah, the quarries are literally washed by the 
waters of the Nile, so that the stone was loweerd at once into the barges. At Kasr-es-Syed,* at Toorah, and other localities situate at some distance from the river, canals dug expressly for the purpose conveyed

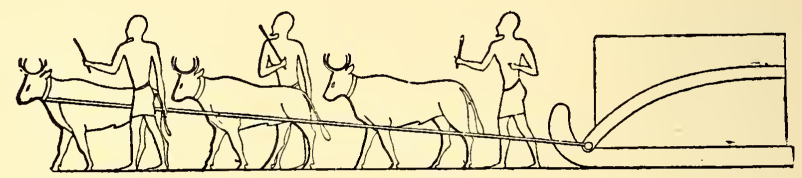

Fig. $48 . \dagger$

the transport boats to the foot of the cliffs. When water transit was out of the question, the stone was placed on sledges drawn by oxen (fig. 48), or dragged to its destination by gangs of labourers, and by the help of rollers.

* Chenoboscion.

$\dagger$ Rude bas-relief sculpture in the quarries of Toorah. 


\section{CHAPTER II.}

\section{RELIGIOUS ARCHITECTURE.}

In the civil and military architecture of ancient Egypt, brick played the principal part; but in the religious architecture of the nation it occupied a very secondary position. The Pharaohs were ambitious of building eternal dwellings for their deities, and stone was the only material which seemed sufficiently durable to withstand the ravages of time and man.

\section{I.-MATERIALS AND PRINCIPLES OF CONSTRUCTION.}

It is an error to suppose that the Egyptians employed only large blocks for building purposes. The size of their materials varied very considerably according to the uses for which they were destined. Architraves, drums of columns, lintel-stones, and door-jambs were sometimes of great size. The longest architraves known -those, namely, which bridge the central nave of the hypostyle hall of Karnak-have a mean length of 30 feet. They each contain 40 cubic yards, and weigh about 65 tons. Ordinarily, however, the blocks are not much larger than those now used in Europe. They measure, that is to say, about $2 \frac{1}{2}$ to 4 feet in height, from 3 to 8 feet in length, and from 2 to 6 feet in thickness.

Some temples are built of only one kind of stone; 
but more frequently materials of different kinds are put together in unequal proportions. Thus the main part of the temples of Abydos consists of very fine limestone; but in the temple of Seti I., the columns, architraves, jambs, and lintels, - all parts, in short, where it might be feared that the limestone would not offer sufficient resistance,- the architect has had recourse to sandstone; while in that of Rameses II., sandstone, granite, and alabaster were used. At Karnak, Luxor, Tanis, and Memphis, similar combinations may be seen. At the Ramesseum, and in some of the Nubian temples, the columns stand on massive supports of crude brick. The stones were dressed more or less carefully, according to the positions they were to occupy. When the walls were of medium thickness, as in most partition walls, they are well wrought on all sides. When the wall was thick, the core blocks were roughed out as nearly cubic as might be, and piled together without much care, the hollows being filled up with smaller flakes, pebbles, or mortar. Casing stones were carefully wrought on the faces, and the joints dressed for two-thirds or three-quarters of the length, the rest being merely picked with a point (Note 6). The largest blocks were reserved for the lower parts of the building; and this precaution was the more necessary because the architects of Pharaonic times sank the foundations of their temples no deeper than those of their houses. At Karnak, they are not carried lower than from 7 to Io feet ; at Luxor, on the side anciently washed by the river, three courses of masonry, each measuring about $2 \frac{1}{2}$ feet in depth, form a great platform on which the walls rest; while at the Ramesseum, the 
brickwork bed on which the colonnade stands does not seem to be more than Io feet deep. These are but slight depths for the foundations of such great buildings, but the experience of ages proves that they are sufficient. The hard and compact humus of which the soil of the Nile valley is composed, contracts every year after the subsidence of the inundation, and thus becomes almost incompressible. As the building progressed, the weight of the superincumbent masonry gradually became greater, till the maximum of pressure was attained, and a solid basis secured. Wherever I have bared the foundations of the walls, I can testify that they have not shifted.

The system of construction in force among the ancient Egyptians resembles in many respects that of the Greeks. The stones are often placed together with dry joints, and without the employment of any binding contrivance, the masons relying on the mere weight of the materials to keep them in place. Sometimes they are held together by metal cramps, or sometimes-as in the temple of Seti I., at Abydos-by dovetails of sycamore wood bearing the cartouche of the founder. Most commonly, they are united by a mortarjoint, more or less thick. All the mortars of which I have collected samples are thus far of three kinds: the first is white, and easily reduced to an impalpable powder, being of lime only; the others are grey, and rough to the touch, being mixtures of lime and sand; while some are of a reddish colour, owing to the pounded brick powder with which they are mixed. A judicious use of these various methods enabled the Egyptians to rival the Greeks in their treatment of regular courses, 
equal blocks, and upright joints in alternate bond. If they did not always work equally well, their shortcomings must be charged upon the imperfect mechanical means at their disposal. The enclosure walls, partitions, and secondary façades were upright ; and they raised the materials by means of a rude kind of crane planted on the top. The pylon walls and the principal façades (and sometimes even the secondary façades) were sloped at an angle which varied according to the taste of the architect. In order to build these, they formed inclined planes, the slopes of which were lengthened as the structure rose in height. These two methods were equally perilous; for, however carefully the blocks might be protected while being

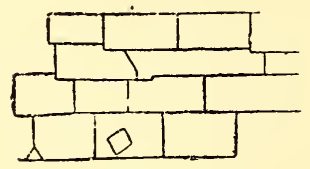

Fig. 49. raised, they were constantly in danger of losing their edges or corners, or of being fractured before they reached the top (Note 7). Thus it was almost always necessary to re-work them; and the object being to sacrifice as little as possible of the stone, the workmen often left them of most abnormal shapes (fig. 49). They would level off one of the side faces, and then the joint, instead of being vertical, leaned askew. If the block had neither height nor length to spare, they made up the loss by means of a supplementary slip. Sometimes even they left a projection which fitted into a corresponding hollow in the next upper or lower course. Being first of all expedients designed to remedy accidents, these methods degenerated into habitually careless ways of working. The masons who had inadvertently hoisted too large a 
block, no longer troubled themselves to lower it back again, but worked it into the building in one or other of the ways before mentioned. The architect neglected to duly supervise the dressing and placing of the blocks. He allowed the courses to vary, and the vertical joints, two or three deep, to come one over the other. The rough work done, the masons dressed down the stone, reworked the joints, and overlaid the whole with a coat of cement or stucco, coloured to match the material, which concealed the faults of the real work. The walls scarcely ever end with a sharp edge. Bordered with a torus, around which a sculptured riband is entwined, they are crowned by a curved cornice surmounted by a flat band (fig. 50); or, as at Semneh, by a square cornice; or, as at Medinet Haboo, by a line of battlements. Thus framed in, the walls looked like enormous panels, each panel complete in

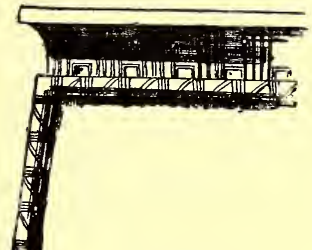

Fig. 50 . itself, without projections and almost without openings. Windows, always rare in Egyptian architecture, are mere ventilators when introduced into the walls of temples, being intended to light the staircases, as in the second pylon of Horemheb at Karnak; or else to support decorative woodwork on festival days. The gateways project but slightly from the body of the buildings (fig. 5I), except where the lintel is overshadowed by a projecting cornice. Real windows occur only in the pavilion of Medinet Haboo; but that building was constructed on the model of a fortress, and must rank as an exception among religious monuments. 
The ground-level of the courts and halls was flagged with rectangular paving stones, well enough fitted,

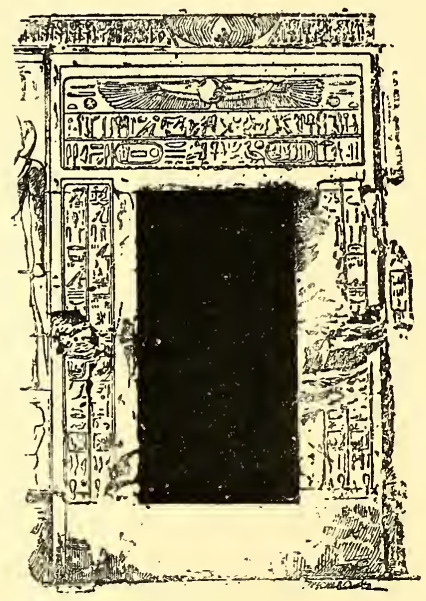

Fig. 5I. except in the intercolumniations, where the architects, hopeless of harmonising the lines of the pavement with the curved bases of the columns, have filled in the space with small pieces, set without order or method (fig. 52). Contrary to their practice when house building, they have scarcely ever employed the vault or arch in temple architecture. We nowhere meet with it, except at Dayr-el-Baharee, and in the seven parallel sanctuaries of Abydos. Even in these instances, the arch is produced by corbelling; that is to say, the curve is formed by three or four superimposed horizontal courses of stone, chiselled out to the form required (fig. 53).

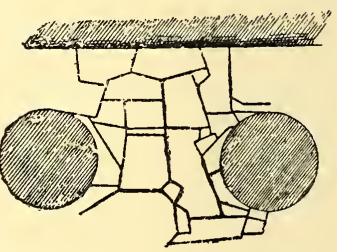

Fig. 52.-Pavement of the portico of Osiris in the temple of Seti I. at Abydos. The ordinary roofing consists of flat paving slabs. When the space between the walls was not too wide, these slabs bridged it over at a single stretch; otherwise the roof had to be supported 
at intervals, and the wider the space the more these supports needed to be multiplied. The supports were connected by immense stone architraves, on which the roofing slabs rested.

The supports are of two types, - the pillar and the column. Some are cut from a single block. Thus, the monolithic pillars of the temple of the sphinx (Note 8), the oldest hitherto found, measure 16 feet in height by $4 \frac{1}{2}$ feet in width. Monolithic columns of red granite are also found among the ruins of Alexandria, Bubastis, and Memphis, which date from the reigns of Hor-emheb and Rameses II., and measure some 20 to 26 feet in height. But these are exceptional. Columns and pillars are commonly built in courses, which are often unequal and

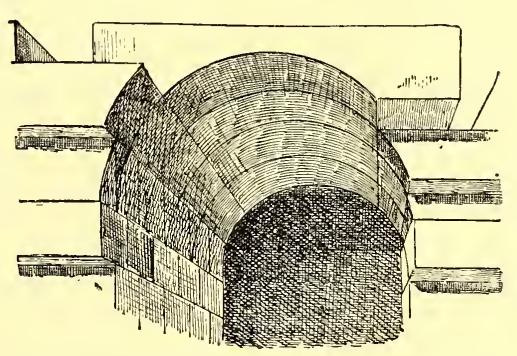

Fig. 53. irregular, like those of the walls which surround them. The great columns of Luxor are not even solid, twothirds of the diameter being filled up with yellow cement, which has lost its strength, and crumbles between the fingers. The capital of the column of Taharka at Karnak contains three courses, each about 4.8 inches high. The last and most projecting course is made up of twentysix convergent stones, which are held in place by merely the weight of the abacus. The:same carelessness which we have already noted in the workmanship of the walls is found in the workmanship of the columns. 
The quadrangular pillar, with parallel or slightly inclined sides, and generally without either base or capital, frequently occurs in tombs of the ancient empire. It reappears later at Medinet $\mathrm{Haboo}$, in the temple of Thothmes III., and again at Karnak, in what is known as the processional hall. The sides of these square pillars are often covered with painted scenes, while the front faces were more decoratively treated, being sculptured with lotus or papyrus stems in high relief, as on the pillar-stelæ of Karnak, or

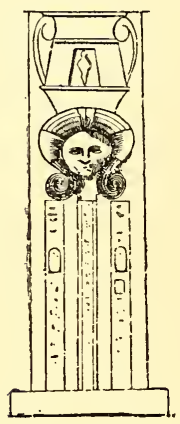

Fig. 54 . adorned with a head of Hathor crowned with the sistrum, as in the small speos of Aboosimbel (fig. 54), or sculptured with a full-length standing figure of Osiris, as in the second court of Medinet Haboo; or, as at Denderah and Gebel Barkal, with the figure of the god Bes. At Karnak, in an edifice which was probably erected by Hor-em-heb with building material taken from the ruins of a sanctuary of Amenhotep II., the pillar is capped by a cornice, separated from the architrave by a thin abacus (fig. 55). By cutting away its four edges, the square pillar becomes an octagonal prism, and further, by cutting off the eight new edges, it becomes a sixteensided prism. Some pillars in the tombs of Assouan and Beni Hassan, and in the processional hall at Karnak (fig. 56), as well as in the chapels of Dayr-el-Baharee, are of this type. Besides the forms thus regularly evolved, there are others of irregular derivation, with six, twelve, fifteen, or twenty sides, or verging almost upon a perfect circle. The portico pillars of the 
temple of Osiris at Abydos come last in the series; the drum is curved, but not round, the curve being interrupted at both extremities of the same diameter by a flat stripe. More frequently the sides are slightly channelled; and sometimes, as at Kalabsheh, the flutings are divided into four groups of five each by five vertical flat stripes (fig. 57). The polygonal pillar is always surmounted by a wide, flat, disc-shaped cap stone. At $\mathrm{El} \mathrm{Kab}$ it bears a head of Hathor, sculptured in relief upon the front (fig. 58); but almost everywhere else it is crowned with a simple square abacus, which joins it to the architrave. Thus treated, it bears a certain family likeness to the Doric column ; and one understands how Jomard and

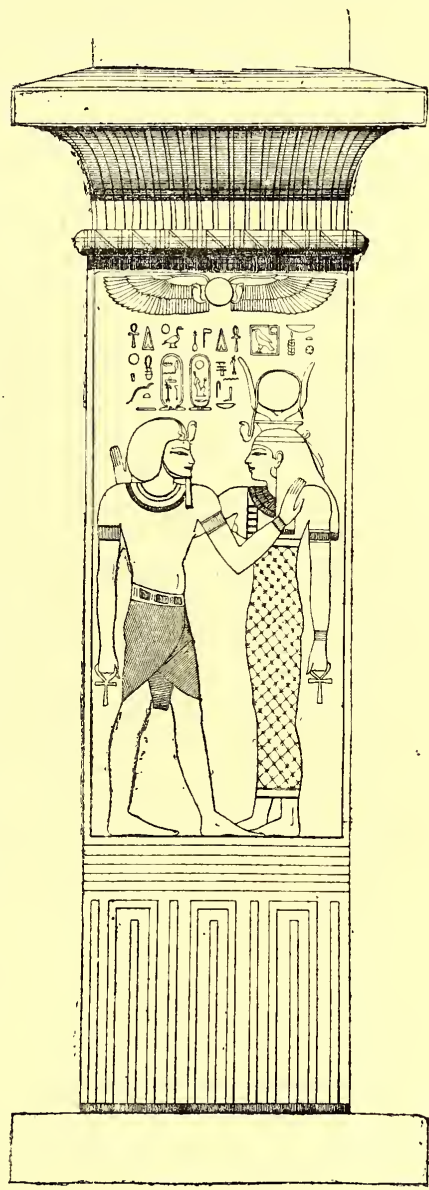

Fig. 55 .

Champollion, in the first ardour of discovery, were tempted to give it the scarcely justifiable name of "proto-Doric." 
The column does not rest immediately upon the soil. It is always furnished with a base like that of the polygonal pillar, sometimes square with the ground, and sometimes slightly rounded. This base is either plain, or ornamented only with a line of hieroglyphs. The principal forms fall into three types: (I) the

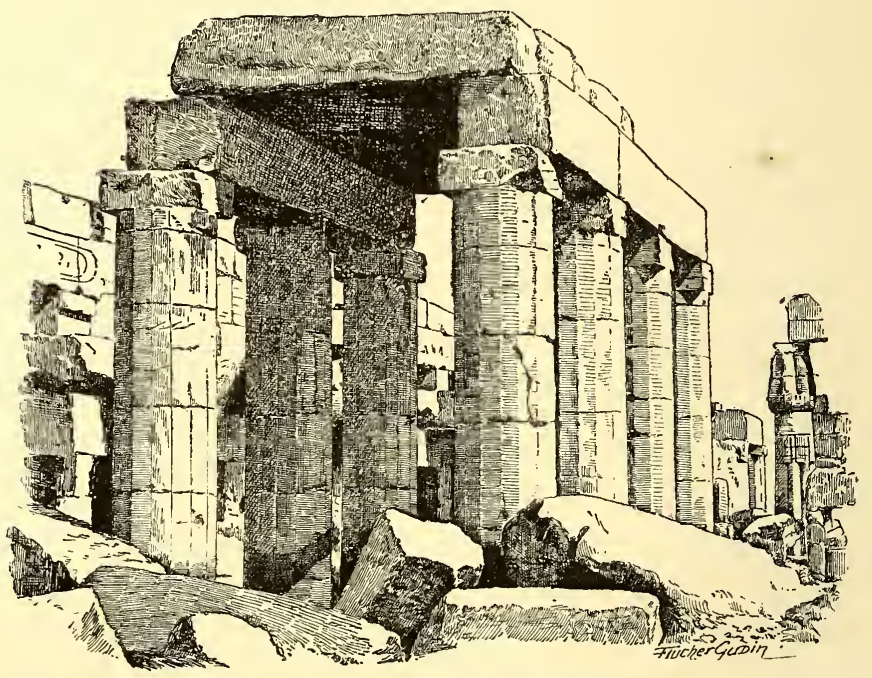

Fig. 56.

column with lotus flower capital; ${ }^{*}$ (2) the column with lotus bud capital; (3) the Hathor-headed capital.

I. Columns with Lotus Flower Capitals.-The shaft is generally plain, or merely engraved with inscriptions or bas-reliefs. Sometimes, however, as at Medamot,

* To this capital Professor Maspero gives the name of "Campaniform"; but to English readers the term "lotus-flower" will be more familiar. [Translator's note.] 
it is formed of six large and six small colonnettes in alternation. In Pharaonic times, it is bulbous, being curved inward at the base, and ornamented with triangles one within another, imitating the large leaves which sheathe the sprouting plant. The curve is so regulated that the diameter at the base and the top shall be about equal. In the Ptolemaic period, the bulb often disappears, owing probably to Greek influences. The columns which surround the first court at Edfoo rise straight from their bases. The shaft always tapers towards the top. It is

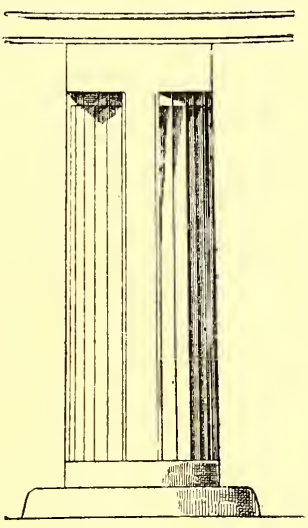

Fig. 57. finished by three or five flat bands, one above the other. At Medamot, where the shaft

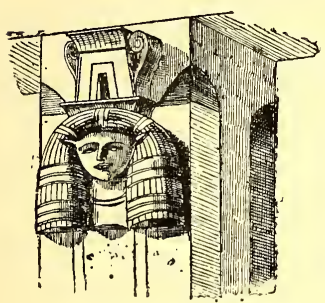

Fig. 58. is clustered, the architect has doubtless thought that one tie at the top appeared insufficient to hold in a dozen colonnettes; he has therefore marked two other rings of bands at regular intervals. The Lotus Flower capital is decorated from the spring of the curve with a row of leaves, like those which sheathe the base. Between these are figured shoots of lotus and papyrus in flower and bud. The height of the capital, and the extent of its projection beyond the line of the shaft, 
varied with the taste of the architect. At Luxor, the

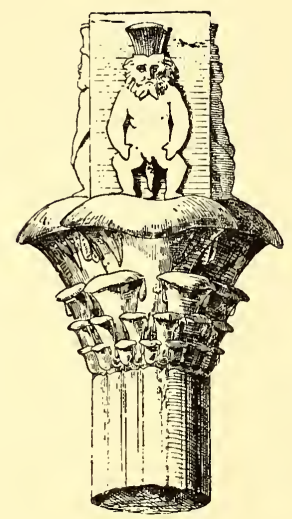

Fig. 59 .

Lotus Capitals are eleven and a half feet in diameter below the re-curved lip, eighteen feet in diameter at the top, and eleven and a half feet in height. At Karnak, in the hypostyle hall, the height of the capital is twelve and a quarter feet, and the greatest diameter twenty-one feet. A square die surmounts the whole. This die is almost hidden by the curve of the capital, though occasionally, as at Denderah, it is higher, and bears on each face a figure of the god Bes (fig. 59).

The Lotus Flower capital is mostly employed in the middle avenue of hypostyle halls, as at Karnak, the Ramesseum, and Luxor (fig. 60); but it was not restricted to this position, for we also find it in porticoes, as at Medinet Haboo, Edfoo, and Philæ. The processional hall* of Thothmes III., at Karnak, contains one most curious variety

* French "Promenoir"; this is perhaps best expressed by "Processional Hall," in accordance with the descrip-
tion of its purpose in a subsequent page. Hall," in accordance with the descrip-
tion of its purpose in a subsequent page. [Translator's note.]

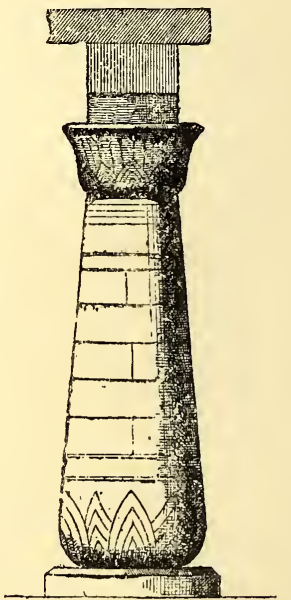

Fig. 6o. 
(fig. 6I); the flower is inverted like a bell, and the shaft is turned upside down, the smaller end being sunk in the plinth, while the larger is fitted to the wide part of the overturned bell. This ungraceful innovation achieved no success, and is found nowhere else. Other novelties were happier, especially those which enabled the artist to introduce decorative elements taken from the flora of the country. In the earlier examples at Soleb, Sesebeh, Bubastis, and Memphis, we find a crown of palm branches springing from the band, their heads being curved beneath the weight of the abacus (fig. 62). Later on, as we

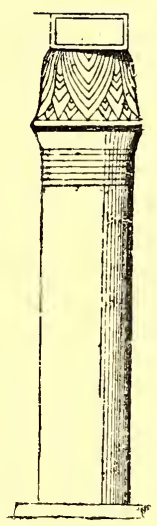

Fig. 6r. approach the Ptolemaic period, the date and the half-

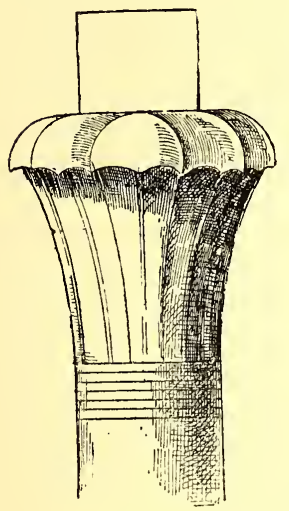

Fig. 62. unfolded lotus were added to the palm-branches (fig. 63). Under the Ptolemies and the Cæsars the capital became a complete basket of flowers and leaves, ranged row above row, and painted in the brightest colours (fig. 64). At Edfoo, Ombos, and Philæ

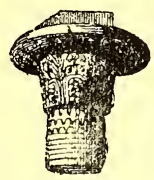

Fig. 63 . one would fancy that the designer had vowed never to repeat the same pattern in the same portico.

II. Columns with Lotus Bud Capitals.-Originally these may perhaps have repre- 
sented a bunch of lotus plants, the buds being bound
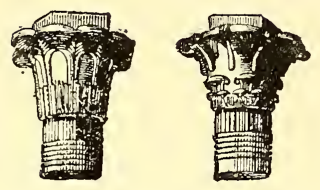

Fig. 64.

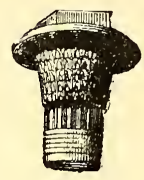

together at the neck to form the capital. The columns of Beni Hassan consist of four rounded stems (fig. 65). Those of the Labyrinth, of the processional hall of Thothmes III., and of Medamot, consist of eight

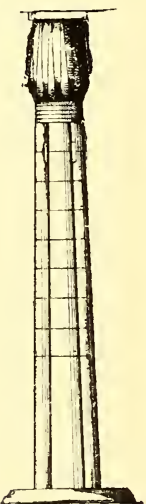

Fig. 65 . stems, each presenting a sharp edge on the outer side (fig. 66). The bottom of the column is bulbous, and set round with triangular leaves. The top is surrounded by three or five bands. A moulding composed of groups of three vertical stripes hangs like a fringe from the lowest band in the space between every two stems. So varied a surface does not admit of hieroglyphic decoration;

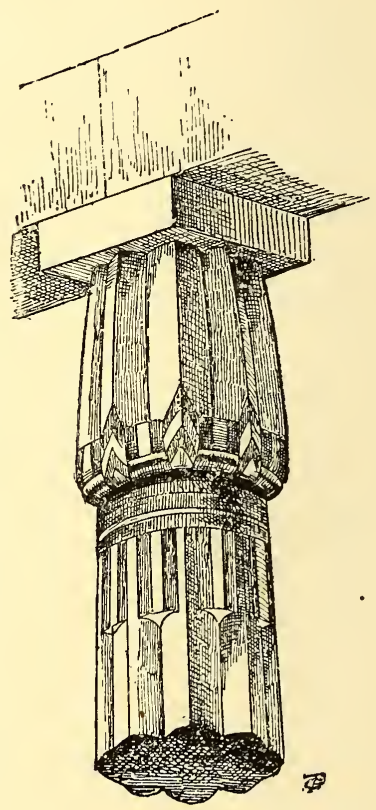

Fig. 66. therefore the projections were by degrees suppressed, and the whole shaft was made smooth. In the 
hypostyle hall at Goorneh, the shaft is divided in three parts, the middle one being smooth and covered with sculptures, while the upper and lower divisions are formed of clustered stems. In the temple of Khonsu, in the side aisles of the hypostyle hall of Karnak, and in the portico of Medinet Haboo, the shaft is quite smooth, the fringe alone being retained below the top bands, while a slight ridge between each of the three bands recalls the original stems (fig. 67). The capital underwent a like process of degradation. At Beni Hassan, it is finely clustered throughout its height. In the processional hall of Thothmes III., at Luxor, and at Medamot, a circle of small pointed leaves and channellings around the base lessens the effect, and reduces it to a mere grooved and truncated cone.

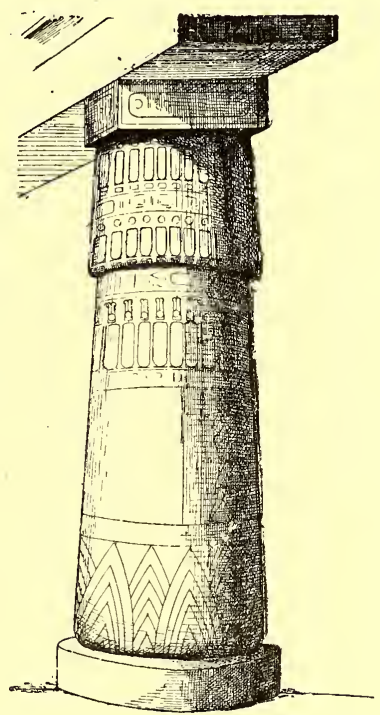

Fig. 67.-Column in the side aisles of the hypostyle hall at Karnak.

In the hypostyle hall of

Karnak, at Abydos, at the Ramesseum, and at Medinet Haboo, various other ornaments, as triangular leaves, hieroglyphic inscriptions, or bands of cartouches flanked by uræi, fill the space thus unfortunately obtained. Neither is the abacus hidden as in the lotus flower capital, but stands out 
boldly, and displays the cartouch of the royal founder.

III. Hathor-headed Columns.-We find examples of the Hathor-headed column dating from ancient times, as at Dayr-el-Baharee; but this order is best known in buildings of the Ptolemaic period, as at ContraLatopolis, Philæ, and Denderah. The shaft and the base present no special characteristics. They resemble those of the Lotus Flower columns.

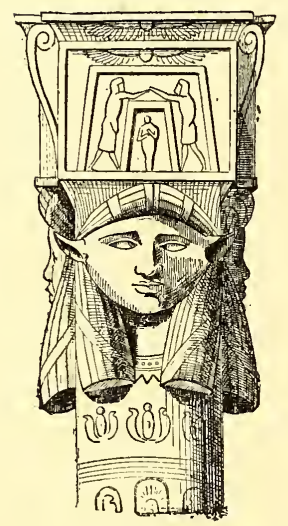

Fig. 68. The capital is in two divisions. Below we have a square block, bearing on each face a woman's head in high relief. The woman has the ears of a heifer. Her hair, confined over the brow by three vertical bands, falls behind the ears, and hangs long on the shoulders. Each head supports a fluted cornice, on which stands a naos framed between two volutes, and crowned by a slender abacus (fig. 68). Thus each column has for its capital four heads of Hathor. Seen from a distance, it at once recalls the form of the sistrum, so frequently represented in the bas-reliefs as held in the hands of queens and goddesses. It is in fact a sistrum, in which the regular proportions of the parts are disregarded. The handle is gigantic, while the upper part of the instrument is unduly reduced. This notion so pleased the Egyptian fancy that architects did not hesitate to combine the sistrum design with elements borrowed from 
other orders. The four heads of Hathor placed above a Lotus Flower capital, furnished Nectanebo with a composite type for his pavilion at Philæ (fig. 69). I cannot say that the compound is very satisfactory, but the column is in reality less ugly than it appears in engravings.

Shafts of columns were regulated by no fixed rules of proportion or arrangement. The architect might, if he chose, make use of equal heights with very different diameters, and, regardless of any considerations apart from those of general harmony, might design the various parts according to whatever scale best suited him. The dimensions of the capital had no invariable connection with those of the shaft, nor was the height of the shaft dependent on the diameter of the column. At Karnak, the lotus flower columns of the hypostyle hall measure IO feet high in the capital, and 55 feet high

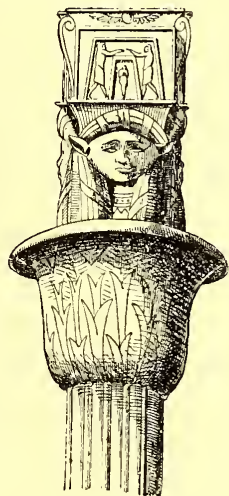

Fig. 69. in the shaft, with a lower diameter of I I feet 8 inches. At Luxor, the capital measures II $\frac{1}{2}$ feet, the shaft 49 feet, and the diameter at the spring of the base I I $\frac{1}{4}$ feet. At the Ramesseum, the shaft and capital measure 35 feet, and the spring diameter is $6 \frac{1}{2}$ feet. The lotus bud, or clustered, column gives similar results. At Karnak, in the side-aisles of the hypostyle hall, the capital is Io feet high, the shaft 33 feet, and the base diameter $6 \frac{3}{4}$ feet. At the Ramesseum, the capital is $5 \frac{1}{2}$ feet high, the shaft $24 \frac{1}{2}$ 
feet, and the base diameter 5 feet ro inches. We find the same irregularity as to architraves. Their height is determined only by the taste of the architect or the necessities of the building. So also with the spacing of columns. Not only does the inter-columnar space

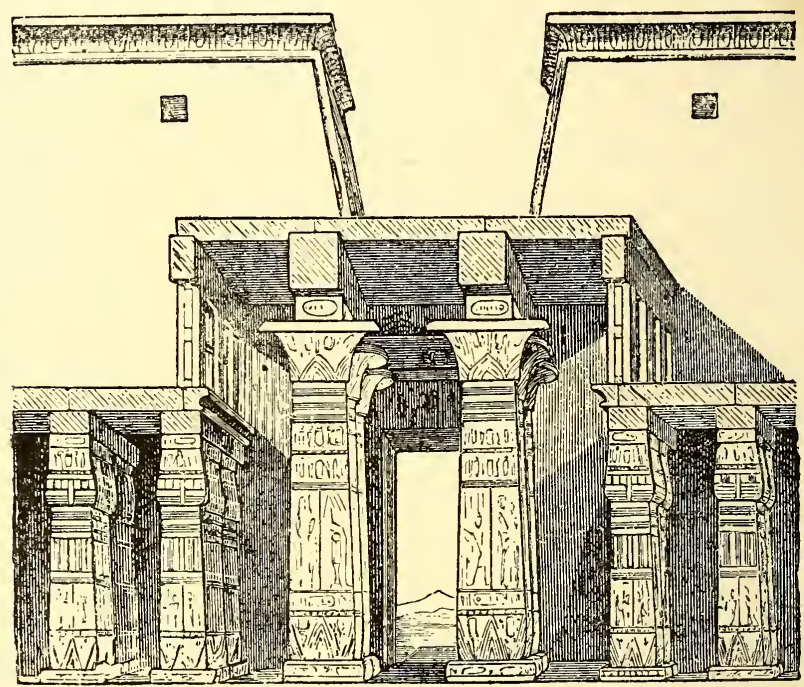

Fig. 70.- Section of the hypostyle hall at Karnak to show the arrangement of the two varieties: lotus flower and lotus bud columns.

vary considerably between temple and temple, or chamber and chamber, but sometimes-as in the first court at Medinet Haboo-they vary in the same portico. We have thus far treated separately of each type; but when various types were associated in a single building, no fixed relative proportions were observed. In the hypostyle hall at Karnak, the lotus flower columns support the loftiest nave, while the lotus 
bud variety is relegated to the side aisles (fig. 70). There are halls in the temple of Khonsu where the lotus-bud column is the loftiest, and others where the lotus flower dominates the rest. In what remains of the Medamot structure, lotus flower and lotus bud columns are of equal height. Egypt had, in short, no definite orders like those of Greece. She tried every combination to which the elements of the column could be made to lend themselves, without ever having formulated rules precise enough to enable us to determine from one of its members the dimensions of the rest.

\section{2.- THE TEMPLE.}

Most of the famous sanctuaries-Denderah, Edfoo, Abydos-were founded before Menes by the Servants of Hor. ${ }^{*}$ Becoming dilapidated or ruined in the course of ages, they have been restored, rebuilt, remodelled, one after the other, till nothing remains of the primitive design to show us what the first Egyptian architecture was like. The funerary temples built by the kings of the Fourth Dynasty have left some traces. That of the second pyramid of Gizeh was so far preserved at the beginning of the last century, that Maillet saw four large pillars standing. It is now almost entirely destroyed; but this loss has been more than compensated by the discovery, in $\mathrm{I} 853$, of a temple situate

* Hor-shesu, "followers," or "servants of Horus," are mentioned in the Turin papyrus as the predecessors of Mena, and are referred to in monumental inscriptions as representing the pre-historic people of Egypt. It is to the Hor-shesu that Professors Maspero and Mariette attribute the making of the Great Sphinx. [Translator's note.] 
about fifty yards to the southward of the sphinx (fig. 7 I). The façade is still hidden by the sand, and the inside is but partly uncovered. The core masonry is of fine Toorah limestone. The casing, pillars, architraves, and roof were constructed with immense blocks of alabaster or red granite (Note 9). 'The plan is most simple: In the middle (A) is a great hall in shape of the letter $\mathrm{T}$, adorned

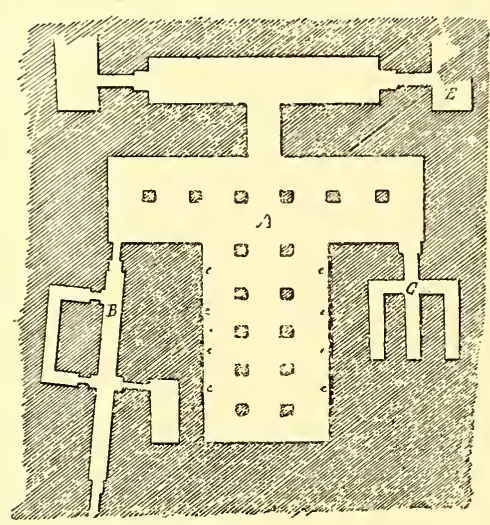

Fig. 7 I. with sixteen square pillars I6 feet in height; at the northwest corner of this hall is a narrow passage on an inclined plane (B), by which the building is now entered; at the south-west corner is a recess which contains six niches, in pairs one over the other. A

long gallery (D), opening at each end into a square chamber, now filled with rubbish (E, E), completes the plan. Without any main door, without windows, and entered through a passage too long to admit the light of day, the building can only have received light and air through slanting air-slits in the roofing, of which traces are yet visible on the tops of the walls $(e, e)$ on each side of the main hall (Note IO). Inscriptions, bas-reliefs, paintings, such as we are accustomed to find everywhere in Egypt, are all 
wanting; and yet these bare walls produce as great an impression upon the spectator as the most richly decorated temples of Thebes.* Not only grandeur but sublimity has been achieved in the mere juxtaposition of blocks of granite and alabaster, by means of purity of line, and by exactness of proportion.

Some few scattered ruins in Nubia, the Fayoom, and Sinai, do not suffice to prove whether the temples of the Twelfth Dynasty merited the praises lavished on them in contemporary inscriptions. Those of the Theban kings, of the Ptolemies, and of the Cæsars which are yet standing are in some cases nearly perfect, while almost all are easy of restoration to those who conscientiously study them upon the spot. At first sight, they seem to present an infinite variety as to arrangement; but on a closer view they are found to conform to a single type. We will begin with the sanctuary. This is a low, small, obscure, rectangular chamber, inaccessible to all save Pharaoh and the priests. It habitually contained neither statue nor emblem, but only the sacred bark, or a tabernacle of painted wood placed upon a pedestal. A niche in the wall, or an isolated shrine formed of a single block of stone, received on certain days the statue, or inanimate symbol of the local god, or the living animal, or the image of the animal, sacred to that god. A temple must necessarily contain this one chamber; and if it

* That is, as we now see it; but that it was originally decorated with statues, etc., is evident from the fact that one almost perfect portraitstatue of Khafra, and the remains of eight others, were found in the temple, besides some large syenite figures of cynocephali; these last being the earliest known examples of figures of sacred animals. [Translator's note.] 
contained but this one chamber, it would be no less a temple than the most complex buildings. Very rarely, however, especially in large towns, was the service of the gods thus limited to the strictly necessary. Around the sanctuary, or "divine house," was grouped a series of chambers in which sacrificial and ceremonial objects were stored, as flowers, perfumes, stuffs, and precious vessels. In advance of this block of buildings were next built one or more halls supported on columns; and in advance of these came a courtyard, where the priests and devotees assembled. This courtyard was surrounded by a colonnade to which the public had access, and was entered through a gateway flanked by two towers, in front of which were placed statues, or obelisks; the whole being surrounded by an enclosure wall of brickwork, and approached through an avenue of sphinxes. Every Pharaoh was free to erect a hall still more sumptuous in front of those which his predecessors had built; and what he did, others might do after him. Thus, successive series of chambers and courts, of pylons and porticoes, were added reign after reign to the original nucleus; and-vanity or piety prompting the work-the temple continued to increase in every direction, till space or means were wanting.

The most simple temples were sometimes the most beautiful. This was the case as regards the sanctuaries erected by Amenhotep III. in the island of Elephantine, which were figured by the members of the French expedition at the end of the last century, and destroyed by the Turkish governor of Assouan in I822. The best preserved, namely, the south temple (fig. 72), consisted of but a single chamber of sandstone, 
I 4 feet high, 3 I feet wide, and 39 feet long. The walls, which were straight, and crowned with the usual cornice, rested on a platform of masonry some 8 feet above the ground. This platform was surrounded by a parapet wall, breast high. All around the temple ran a colonnade, the sides each consisting of seven square pillars, without capital or base, and the two façades, front and back, being supported by two columns with the lotus bud capital. Both pillars and columns rose direct from the parapet; except on the

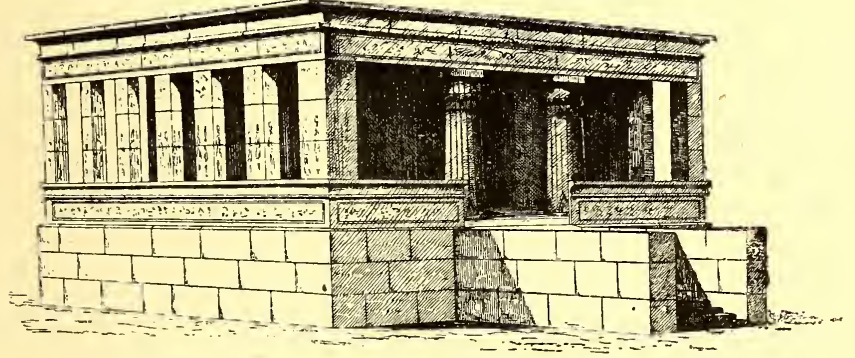

Fig. 72 .

east front, where a flight of ten or twelve steps, enclosed between two walls of the same height as the platform, led up to the cella. The two columns at the head of the steps were wider apart than those of the opposite face, and through the space thus opened was seen a richly-decorated door. A second door opened at the other end, beneath the portico. Later, in Roman times, this feature was utilised in altering the building. The inter-columnar space at the end was filled up, and thus was obtained a second hall, rough and bare, but useful for the purposes of the temple service. These 
Elephantine sanctuaries bring to mind the peripteral temples of the Greeks, and this resemblance to one of the most familiar forms of classical architecture explains perhaps the boundless admiration with which they were regarded by the French savants. Those of Mesheikh, of $\mathrm{El} \mathrm{Kab}$, and of Sharonah are somewhat more

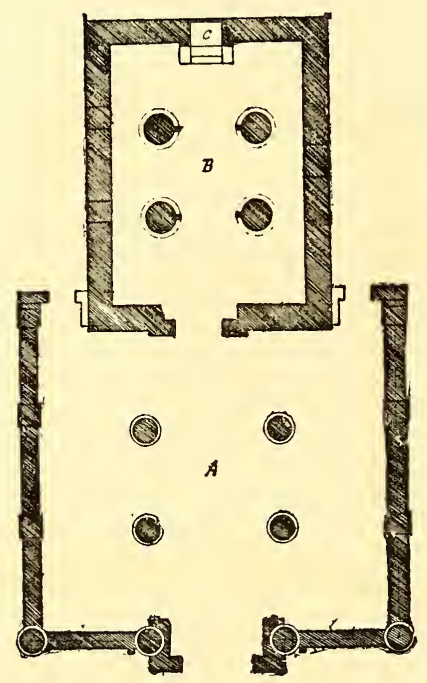
elaborate. The building at $\mathrm{El} \mathrm{Kab}$ is in three divisions (fig. 73); first, a hall of four columns. (A); next, a chamber (B) supported by four Hathorheaded pillars; and in the end wall, opposite the door, a niche (c), approached by four steps. Of these small oratories the most complete model now remaining belongs to the Ptolemaic period; namely, the temple of Hathor at Dayr el Medineh (fig. 74). Its length is

Fig. 73.-Temple of Amenhotep III., at El-Kab. just double its breadth. The walls are built with a batter inclining inwards, ${ }^{*}$ and are externally bare, save at the door, which is framed in a projecting border covered with finely-sculptured scenes. The interior

* That is to say, the wall is vertical on the inside; but is built much thicker at the bottom than at the top, so that on the outside it presents a sloping surface, retiring with the height of the wall. [Translator's note.] 
is in three parts: A portico (B), supported by two lotus flower columns; a pronaos (c), reached by a flight of four steps, and separated from the portico by a wall which connects the two lotus flower columns with two Hathor-headed pilasters in antis; lastly, the sanctuary (D), flanked by two small chambers (E, E), which are lighted by square openings cut in the ceiling. The ascent to the terrace is by way of a staircase, very ingeniously placed in the south corner of the portico, and furnished with a beautiful open window (F). This is merely a temple in miniature; but the parts, though small, are so well proportioned that it would be impossible to conceive anything more delicate or graceful.

We cannot say as much for the temple which the

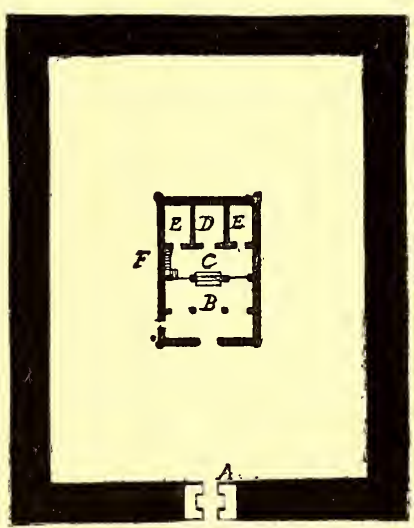

Fig. 74 . Pharaohs of the Twentieth Dynasty erected to the south of Karnak, in honour of the god of Khonsu (fig. 75); but if the style is not irreproachable, the plan is nevertheless so clear, that one is tempted to accept it as the type of an Egyptian temple, in preference to others more elegant or majestic. On analysis, it resolves itself into two parts separated by a thick wall (A, A). In the centre of the lesser division is the Holy of Holies (B), open at both ends and isolated from the rest of the building 
by a surrounding passage (c) IO feet in width. To the right and left of this sanctuary are small dark chambers (D, D), and behind it is a hall of four columns (E), from which open seven other chambers (F, F). Such was the house of the god, having no communication with the adjoining parts, except by two doors (G, G) in

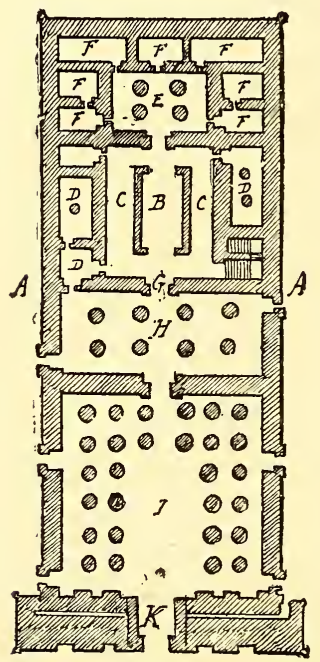

Fig. 75 . the southern wall $(\mathrm{A}, \mathrm{A})$. These opened into a wide and shallow hypostyle hall $(\mathrm{H})$, divided into three naves. The middle nave is supported by four lotus flower columns, 23 feet in height; the sides each containing two lotus bud columns i 8 feet high. The roof of the middle nave is, therefore, 5 feet higher than that of the sides. This elevation was made use of for lighting purposes, the clerestory being fitted with stone gratings, which admitted the daylight. The court (I) was square, and surrounded by a double colonnade entered by way of four side-gates $(\mathrm{J}, \mathrm{J})$, and a great central gateway flanked by two quadrangular towers with sloping fronts. This pylon (x) measures I05 feet in length, 33 feet in width, and 60 feet in height. It contains no chambers, but only a narrow staircase, which leads to the top of the gate, and thence up to the towers. Four long grooves in the façade, reaching to a third of its height, correspond to four quadrangular openings cut through 
the whole thickness of the masonry. Here were fixed four great wooden masts, formed of joined beams and held in place by a wooden framework fixed in the four openings above mentioned. From these masts floated long streamers of various colours (fig. 76). Such was the temple of Khonsu, and such, in their main features, were the majority of the greater temples of Theban and Ptolemaic times, as Luxor, the Ramesseum, Medinet Haboo, Edfoo, and Denderah. Though for the most part half in ruins, they affect one with a strange and disquieting

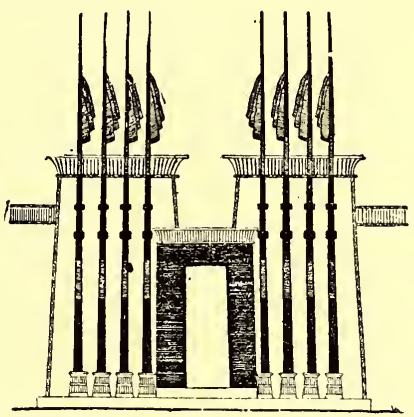

Fig. 76. sense of oppression. As mystery was a favourite attribute of the Egyptian gods, even so the plan of

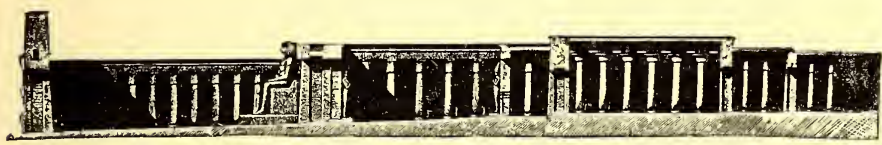

Fig. 77.--The Ramesseum restored, to show the rising of the soil.

their temples is in such wise devised as to lead gradually from the full sunshine of the outer world to the obscurity of their retreat. At the entrance we find large open spaces, where air and light stream freely in. The hypostyle hall is pervaded by a sober twilight ; the sanctuary is more than half lost in a vague darkness; and at the end of the building, in the farthest chambers 
of all, night all but reigns completely. The effect of distance which was produced by this gradual diminution of light, was still further heightened by various

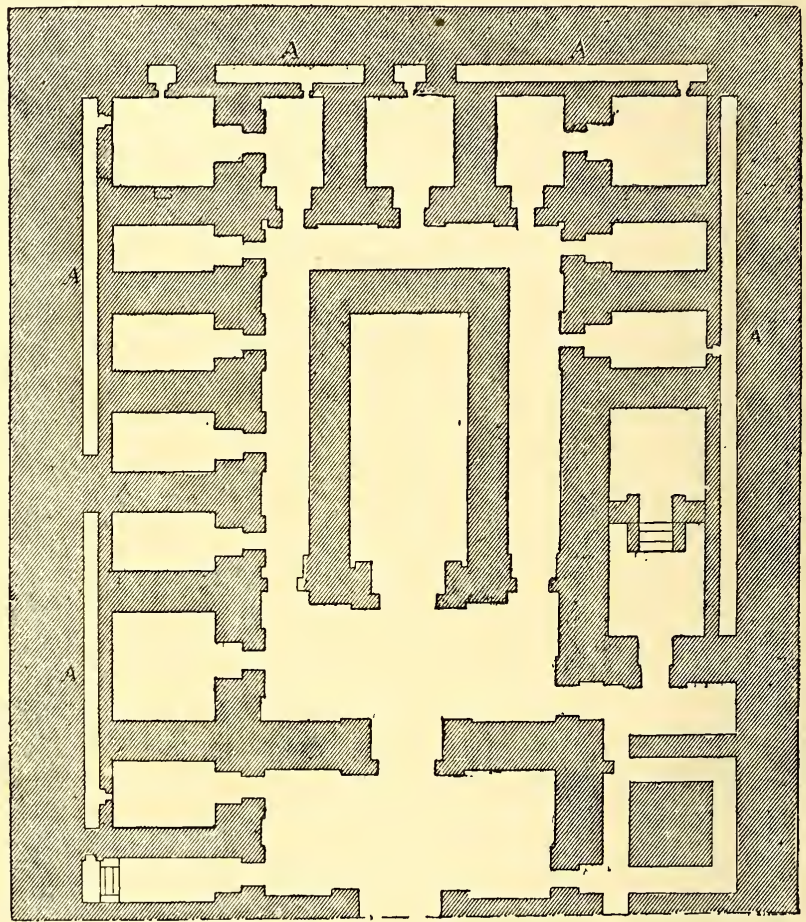

Fig. 78. - Crypts in the thickness of the walls, round the sanctuary at Denderah.

structural artifices. The parts, for instance, are not on the same level. The ground rises from the entrance (fig. 77), and one has always a few steps to mount in passing from one part to another. In the 
temple of Khonsu the difference of level is not more than $5 \frac{1}{4}$ feet, but it is combined with a lowering of the roof, which in most cases is very strongly marked. From the pylon to the wall at the farther end, the height decreases continuously. The peristyle is loftier than

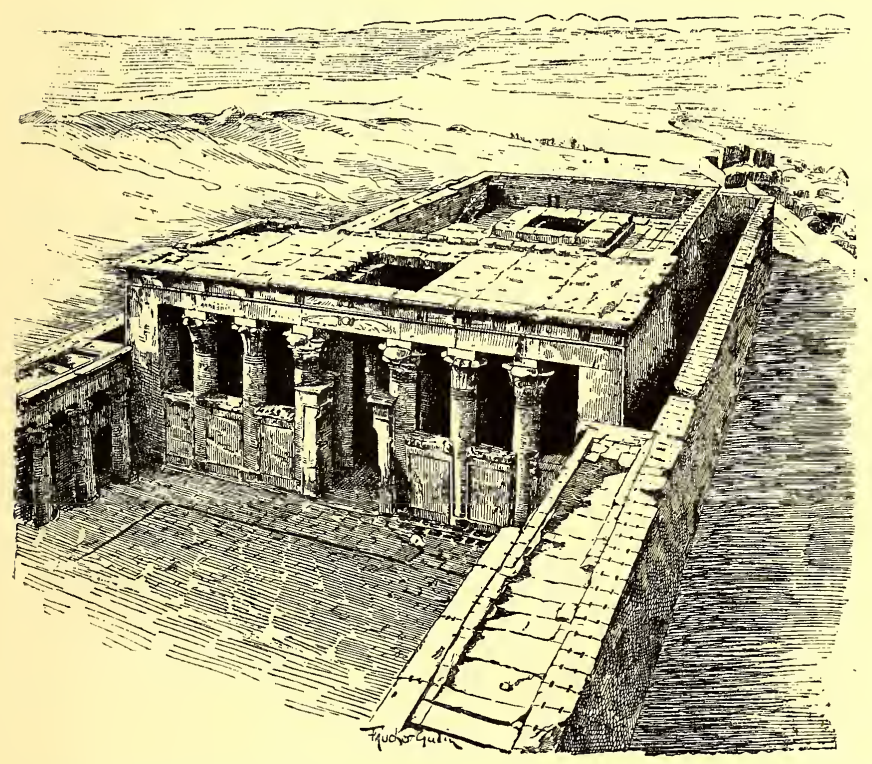

Fig. 79. - The pronaos of Edtoo, as seen from the top of the eastern pylon.

the hypostyle hall, and the hypostyle hall is loftier than the sanctuary. The last hall of columns and the farthest chamber are lower and lower still. The architects of Ptolemaic times changed certain details of arrangement. They erected chapels and oratories on the terraced roofs, and reserved space for the con- 
struction of secret passages and crypts in the thickness of the walls, wherein to hide the treasure of the god (fig. 78). They, however, introduced only two important modifications of the original plan. The sanctuary was formerly entered by two opposite doors; they left but one. Also the colonnade, which was originally continued

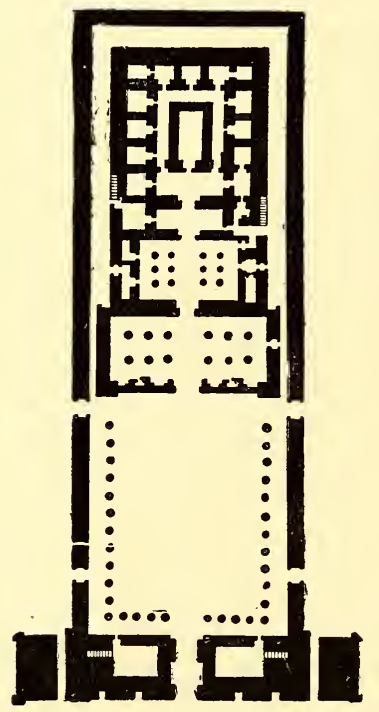

Fig. 8o. round the upper end of the court, or, where there was no court, along the façade of the temple, became now the pronaos, so forming an additional chamber. The columns of the outer row are retained, but built into a wall reaching to about half their height. This connecting wall is surmounted by a cornice, which thus forms a screen, and so prevented the outer throng from seeing what took place within (fig. 79). The pronaos is supported by two, three, or even four rows of columns, according to the size of the edifice. For the rest, it is useful to compare the plan of the temple of Edfoo (fig. 80) with that of the temple of Khonsu, observing how little they differ the one from the other. Thus designed, the building sufficed for all the needs of worship. If it needed to be enlarged, the sanctuary and surrounding chambers were generally 
left untouched, and only the ceremonial parts of the building, as the hypostyles, courts, or pylons, were attacked. The procedure of the Egyptians under these circumstances is best illustrated by the history of the great temple of Karnak.

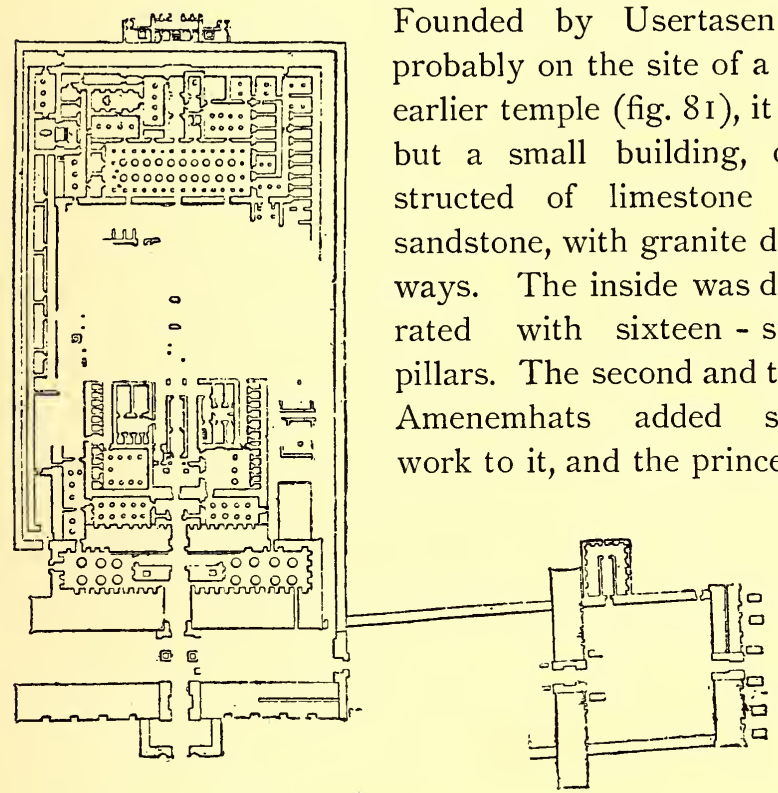

Fig. 8I.-The temple of Karnak up to the reign of Amenhotep III.

the Thirteenth and Fourteenth Dynasties adorned it with statues and tables of offerings. It was still unaltered when, in the eighteenth century B.c., Thothmes I., enriched with booty of war, resolved to enlarge it. In advance of what already stood there, he erected two chambers, preceded by a court and flanked by two isolated chapels. In advance of these again, he erected 
three successive pylons, one behind the other. The whole presented the appearance of a vast rectangle placed crosswise at the end of another rectangle. Thothmes II. and Hatshepsu* covered the walls erected by their father with bas-relief sculptures, but added no more buildings. Hatshepsu, however, in order to bring in her obelisks between the pylons of Thothmes I., opened a breach in the south wall, and overthrew sixteen of the columns which stood in that spot. Thothmes III., probably seeing certain parts of the structure unworthy of the god, rebuilt the first pylon, and also the double sanctuary, which he renewed in the red granite of Syene. To the eastward, he rebuilt some old chambers, the most important among them being the processional hall, used for the startingpoint and halting-place of ceremonial processions; and these he surrounded with a stone wall. He also made the lake whereon the sacred boats were launched on festival days; and, with a sharp change of axis, he built two pylons facing towards the south, thus violating the true relative proportion which had till then subsisted between the body and the front of the general mass of the building. The outer enclosure was now too large for the earlier pylons, and did not properly accord with the later ones. Amenhotep III. corrected this defect. He erected a sixth and yet more massive pylon, which was, therefore, better suited for the façade. As it now stood, the temple surpassed even the boldest architec-

* "Hatshepsu," more commonly known as "Hatasu;" the new reading is, however, the more correct. Professor Maspero, the founder of a new school of scientific transliteration, spells it "Hatshopsitou." [Translator's note.] 
tural enterprises hitherto attempted; but the Pharaohs of the Nineteenth Dynasty succeeded in achieving still more. They added only a hypostyle hall (fig. 82) and a pylon; but the hypostyle hall measured 170 feet in length by 329 feet in breadth. Down the centre they carried a main avenue of twelve columns, with lotus flower capitals, being the loftiest ever erected in the interior of a building, while in the lateral aisles, ranged in seven rows on either side, they planted I 22 columns with lotus bud capitals. The roof of the great nave rose to a height of 75 feet above the level of the ground, and the pylon stood some fifty feet higher still. During a whole century, three kings laboured to perfect this hypostyle hall. Rameses I. conceived the idea; Seti I.

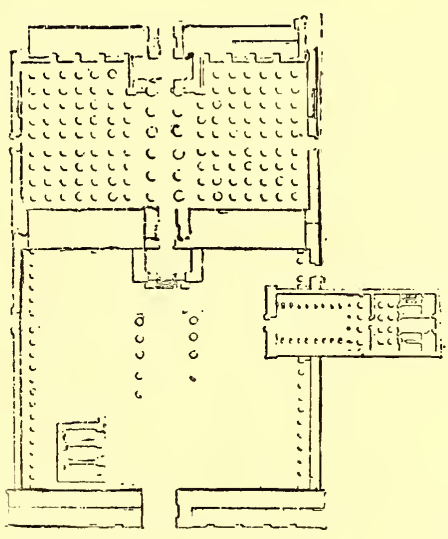

Fig. 82 .

finished the bulk of the work, and Rameses II. wrought nearly the whole of the decoration. The Pharaohs of the next following dynasties vied with each other for such blank spaces as might be found, wherein to engrave their names upon the columns, and so to share the glory of the three founders; but farther they did not venture. Left thus, however, the monument was still incomplete. It still needed one last pylon and a colonnaded court. Nearly three centuries 
elapsed before the task was again taken in hand. At last the Bubastite kings decided to begin the colon-

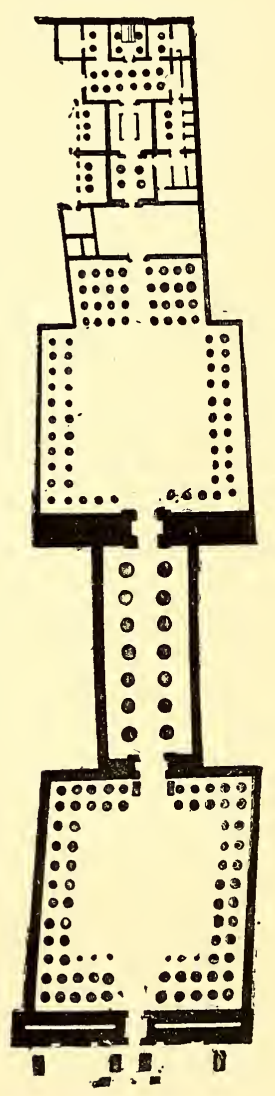

Fig. 83 . nades, but their work was as feeble as their resources were limited. Taharkah, the Ethiopian, imagined for a moment that he was capable of rivalling the great Theban Pharaohs, and planned a hypostyle hall even larger than the first; but he made a false start. The columns of the great nave, which were all that he had time to erect, were placed too wide apart to admit of being roofed over; so they never supported anything, but remained as memorials of his failure. Finally, the Ptolemies, faithful to the traditions of the native monarchy, threw themselves into the work; but their labours were interrupted by revolts at Thebes, and the earthquake of the year 27 B.c. destroyed part of the temple, so that the pylon remained for ever unfinished. The history of Karnak is identical with that of all the great Egyptian temples. When closely studied, the reason why they are for the most part so irregular becomes evident. The general plan is practically the same, and the pro- 
gress of the building was carried forward in the same way; but the architects could not always foresee the future importance of their work, and the site was not always favourable to the development of the building. At Luxor (fig. 83), the progress went on methodically enough under Amenhotep III. and Seti I., but when Rameses II. desired to add to the work of his predecessors, a bend in the river compelled him to turn eastwards. His pylon is not parallel to that of Amenhotep III., and his colonnades make a distinct angle with the general

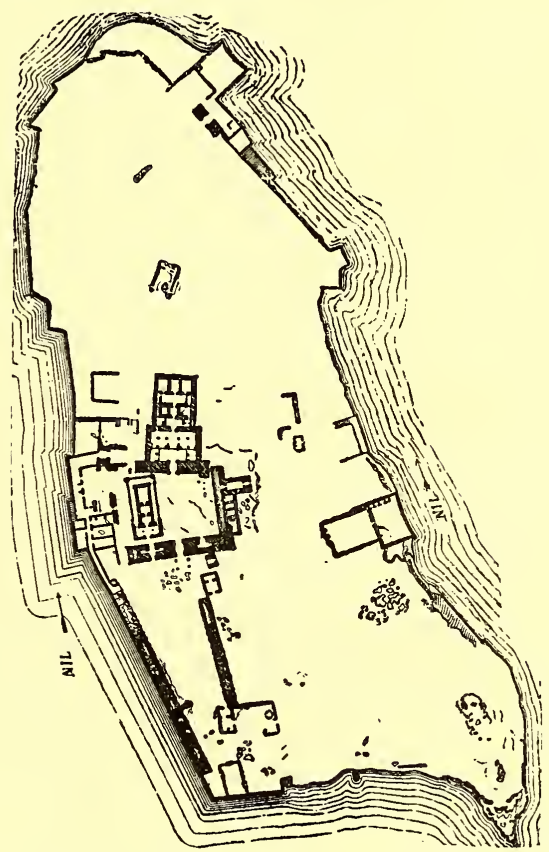

Fig. 84.--Plan of the Isle of Philæ. axis of the earlier work. At Philæ (fig. 84) the deviation is still greater. Not only is the larger pylon out of alignment with the smaller, but the two colonnades are not parallel with each other. Neither are they attached to the pylon with a due regard to symmetry. This arises neither from negligence nor 
wilfulness, as is popularly supposed. The first plan was as regular as the most symmetrically-minded designer could wish; but it became necessary to adapt

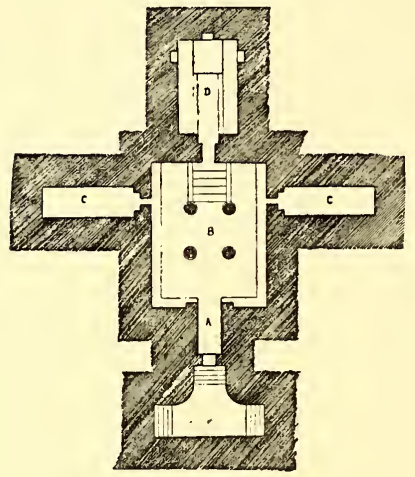

Fig. 85 . it to the requirements of the site, and the architects were thenceforth chiefly concerned to make the best of the irregularities to which they were condemned by the configuration of the ground. Such difficulties were, in fact, a frequent source of inspiration; and Philæ shows with what skill they extracted every element of beauty and picturesqueness from enforced disorder.

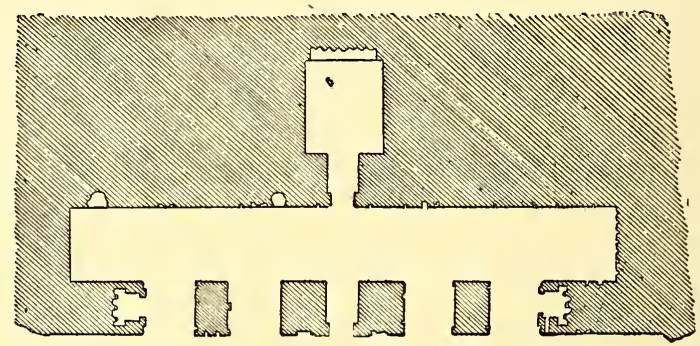

Fig. 86 .

The idea of the rock-cut temple must have occurred to the Egyptians at an early period. They carved the houses of the dead in the mountain side ; why, therefore, should they not in like manner carve the houses of the 
gods? Yet the earliest known Speos-sanctuaries date from only the beginning of the Eighteenth Dynasty. They are generally found in those parts of the valley where the cultivable land is narrowest, as at Beni Hassan, at Gebel Silsileh, and in Nubia. All varieties of the constructed temple are found in the rock-cut temple, though more or less modified by local conditions. The Speos Artemidos is approached by a pillared portico, but contains only a square chamber with a niche at the end (c) for the statue of the goddess Pakht. At Kalaat Addah (fig. 85), a flat narrow façade (A) faces the river, and is reached by a steep flight of steps; next comes a hypostyle hall (B), flanked by two dark chambers (c), and lastly a sanctuary in two storeys, one above the other (D). The chapel of

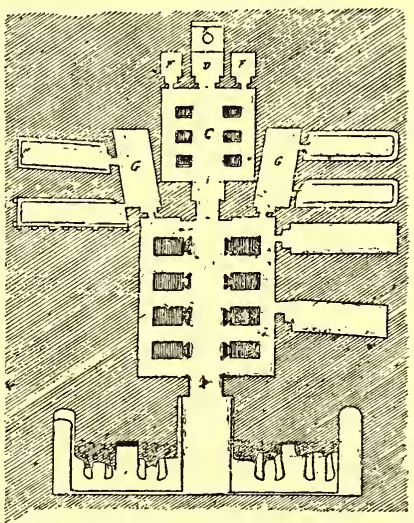

Fig. 87 . Hor-em-heb (fig. 86), at Gebel Silsileh, is formed of a gallery parallel to the river (A), supported by four massive pillars left in the rock. From this gallery, the sanctuary chamber opens at right angles. At Aboo Simbel, the two temples are excavated entirely in the cliff. The front of the great speos (fig. 87) imitates a sloping pylon crowned with a cornice, and guarded as usual by four seated colossi flanked by smaller statues. These colossi are sixty-six feet high. The 
doorway passed, there comes a first hall measuring I 30 feet in length by 60 feet in width, which corres ponds to the usual peristyle. Eight

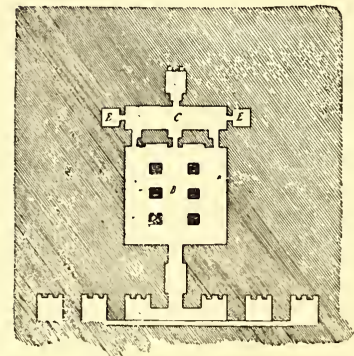

Fig. 88. Osiride statues, backed by as many square pillars, seem to bear the mountain on their heads. Beyond this come (I) a hypostyle hall ; (2) a transverse gallery, isolating the sanctuary, and (3) the sanctuary itself, between two smaller chambers. Eight crypts, sunk at a somewhat lower level than that of the main excavation, are un-

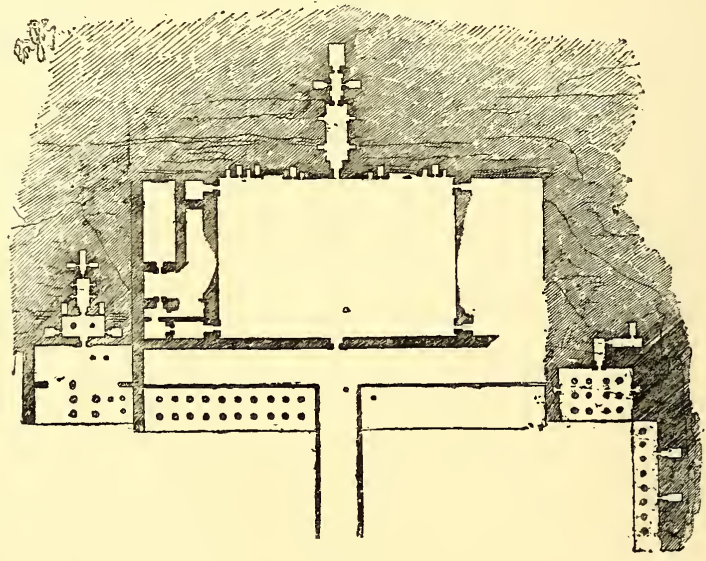

Fig. 89 .

equally distributed to right and left of the peristyle. The whole excavation measures i 80 feet from the doorway to the end of the sanctuary. The small speos of 
Hathor, about a hundred paces to the northward, is of smaller dimensions. The façade is adorned with six standing colossi, four representing Rameses II., and two his wife Nefertari. The peristyle and the crypts are lacking (fig. 88), and the small chambers are placed at either end of the transverse passage, instead of being parallel with the sanctuary. The hypostyle hall, however, is supported by six Hathor-headed pillars. Where space permitted, the rock-cut temple was but partly excavated in the cliff, the forepart being constructed outside with blocks cut and dressed. The speos then became half grotto, half building. At Derr, which is a hemi-speos, only the peristyle is external to the cliff; at Bayt-el-Waly, the pylon and court are built; at Gerf Hosayn and Wady

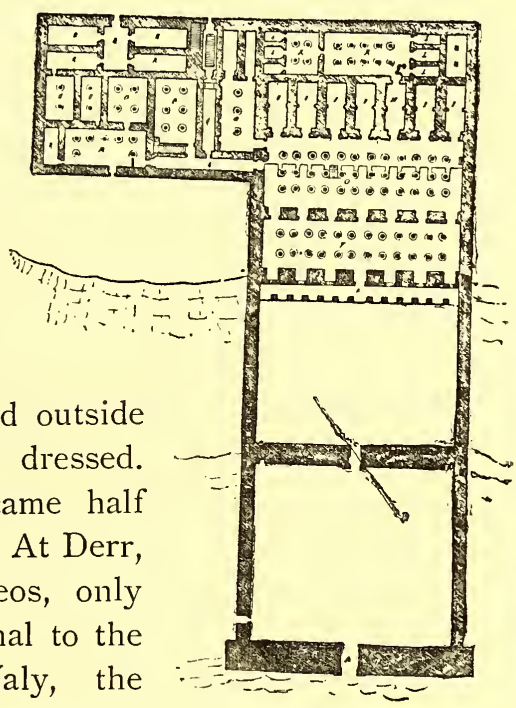

Fig. 90. Sabooah the pylon, court, and hypostyle hall are all outside the mountain. The most celebrated and original hemi-speos is that built by Queen Hatshepsu at Dayrel-Baharee, in the Theban necropolis (fig. 89). The sanctuary and the two chapels which, as usual, accompany it, were cut about IOO ft. above the level of the valley. In order to arrive at that height, slopes were 
made and terraces laid out according to a plan which will not be understood until the site is more thoroughly excavated.

Between the hemi-speos and the isolated temple, the Egyptians created yet another variety, namely, the built temple backed by, but not carried into, the cliff. The temple of the sphinx at Gizeh, and the temple of Seti I. at Abydos, may be cited as two good examples. I have already described the former; the area of the latter (fig. 90) was cleared in a narrow and shallow belt of sand, which here divides the plain from the desert. It was sunk up to the roof, the tops of the walls but just showing above the level of the ground. The staircase which led up to the terraced roof led also to the top of the hill. The front, which stood completely out, seemed in nowise extraordinary. It was approached by two pylons, two courts, and a shallow portico supported on square pillars. The unusual part of the building only began beyond this point. First, there were two hypostyle halls instead of one. These are separated by a wall with seven doorways. There is no middle nave, and the sanctuary opens direct from the second hall. This, as usual, consists of an oblong chamber with a door at each end; but the rooms by which it is usually surrounded are here placed side by side in a line, two to the right and four to the left; further, they are covered by corbelled vaults, and are lighted only from the doors. Behind the sanctuary are further novelties. Another hypostyle hall (k) abuts on the end wall, and its dependencies are unequally distributed to right and left. As if this were not enough, the architect also constructed, to the left of the main building, 
a court, five chambers of columns, various passages and dark chambers-in short, an entire wing branching off at right angles to the axis of the temple proper, with no counterbalancing structures on the other side. These irregularities become intelligible when the site is examined. The cliff is shallow at this part, and the smaller hypostyle hall is backed by only a thin partition of rock. If the usual plan had been followed, it would have been necessary to cut the cliff entirely away, and the structure would have forfeited its special characteristic-that of a temple backed by a cliff-as desired by the founder. The architect, therefore, distributed in width those portions of the edifice which he could not carry out in length; and he even threw out a wing. Some years later, when Rameses II. constructed a monument in memoriam of himself, about a hundred yards to the northward of the older building, he was careful not to follow in his father's footsteps. Seated on the top of an elevation, his temple had sufficient space for development, and the conventional plan was followed in all its strictness.

Most temples, even the smallest, are surrounded by a square enclosure or temenos. At Medinet Haboo, this enclosure wall is of sandstone-low, and embattled. The innovation is due to a whim of Rameses III., who, in giving to his monument the outward appearance of a fortress, sought to commemorate his Syrian victories. Elsewhere, the doorways are of stone, and the walls are built in irregular courses of crude bricks. The great enclosure wall was not, as frequently stated, intended to isolate the temple and screen the priestly ceremonies from eyes profane. It marked the limits of the divine 
dwelling, and served, when needful, to resist the attacks of enemies whose cupidity might be excited by the accumulated riches of the sanctuary. As at Karnak, avenues of sphinxes and series of pylons led up to the various gates, and formed triumphal approaches. The rest of the ground was in part occupied by stables, cellarage, granaries, and private houses. Just as in Europe during the Middle Ages the population crowded most densely round about the churches and abbeys, so in Egypt they swarmed around the temples, profiting by that security which the terror of his name and the solidity of his ramparts ensured to the local deity. A clear space was at first reserved round the pylons and the walls; but in course of time the houses encroached upon this ground, and were even built up against the boundary wall. Destroyed and rebuilt century after century upon the self-same spot, the débris of these surrounding dwellings so raised the level of the soil, that the temples ended for the most part by being gradually buried in a hollow formed by the artificial elevation of the surrounding city. Herodotus mentions this of Bubastis, and on examination it is seen to have been the same in many other localities. At Ombos, at Edfoo, at Denderah, the whole city nestled inside the precincts of the divine dwelling. At El Kab, where the temple temenos* formed a separate enclosure within the boundary of the city walls, it served as a sort of donjon, or keep, in which the garrison could seek a last refuge. At Memphis and at Thebes, there were as many keeps as there were great temples, and these

* Temenos, i.e., the enclosure wall of the Temple, within which all was holy ground. 
sacred fortresses, each at first standing alone in the midst of houses, were, from the time of the Eighteenth Dynasty, connected each with each by avenues of sphinxes. These were commonly andro-sphinxes, com-

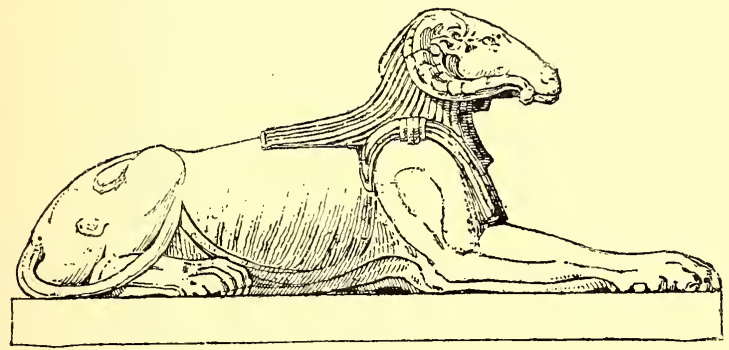

Fig. 91.

bining the head of a man and the body of a lion ; but we also find crio-sphinxes, which united a ram's head with a

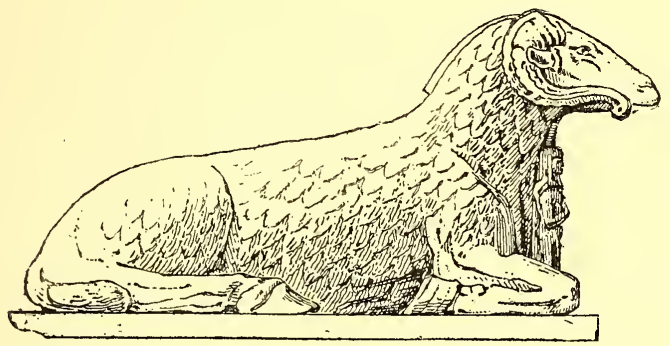

Fig. 92.

lion's body (fig. 9I). Elsewhere, in places where the local worship admitted of such substitution, a couchant ram, holding a statuette of the royal founder between his bent forelegs, takes the place of the conventional sphinx (fig. 92). The avenue leading from Luxor to 
Karnak was composed of these diverse elements. It was one mile and a quarter in length, and there were many bends in it; but this fact affords no fresh proof of Egyptian "symmetrophobia." The enclosures of the two temples were not oriented alike, and the avenues which started squarely from the fronts of each could never have met had they not deviated from their first course. Finally, it may be said that the inhabitants of Thebes saw about as much of their temples as we see at the present day. The sanctuary and its immediate surroundings were closed against them; but they had access to the façades, the courts, and even the hypostyle halls, and might admire the masterpieces of their architects as freely as we admire them now.

\section{3.-Decoration.}

Ancient tradition affirmed that the earliest Egyptian temples contained neither sculptured images, inscriptions, nor symbols ; and in point of fact, the Temple of the Sphinx is bare. But this is a unique example. The fragments of architraves and masonry bearing the name of Khafra, which were used for building material in the northern pyramid of Lisht, show that this primitive simplicity had already been abandoned by the time of the Fourth Dynasty. During the Theban period, all smooth surfaces, all pylons, wall-faces, and shafts of columns, were covered with figure-groups and inscriptions. Under the Ptolemies and the Cæsars, figures and hieroglyphs became so crowded that the stone on which they are sculptured seems to be lost under the masses of ornament with which it is charged. One recognises at a 
glance that these scenes are not placed at random. They follow in sequence, are interlinked, and form as it were a great mystical book in which the official relations between gods and men, as well as between men and gods, are clearly set forth for such as are skilled to read it. The temple was built in the likeness of the world, as the world was known to the Egyptians. The earth, as they believed, was a flat and shallow plane, longer than its width. The sky, according to some, extended overhead like an immense iron ceiling, and according to others, like a huge shallow vault. As it could not remain suspended in space without some support, they imagined it to be held in place by four inmense props or pillars. The floor of the temple naturally represented the earth. The columns, and if needful the four corners of the chambers, stood for the pillars. The roof, vaulted at Abydos, flat elsewhere, corresponded exactly with the Egyptian idea of the sky. Each of these parts was, therefore, decorated in consonance with its meaning. Those next to the ground were clothed with vegetation. The bases of the columns were surrounded by leaves, and the lower parts of the walls were adorned with long stems of lotus or papyrus (fig. 93), in the midst of which animals were occasionally depicted. Bouquets of water-plants emerging from the water (fig. 94), enlivened the bottom of the wall-space in certain chambers. Elsewhere, we find full-blown flowers interspersed with buds (fig. 95), or tied together with cords (fig. 96); or those emblematic plants which symbolise the union of Upper and Lower Egypt under the rule of a single Pharaoh (fig. 97); or birds with human hands and arms, perched in an attitude of adoration on the 
sign which represents a solemn festival; or kneeling prisoners tied to the stake in couples, each couple con-

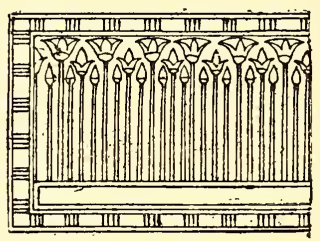

Fig. 93 .

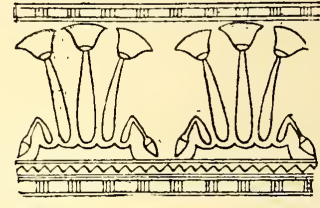

Fig. 94.

sisting of an Asiatic and a negro (fig. 98). Male and female Niles (fig. 99), laden with flowers and fruits,

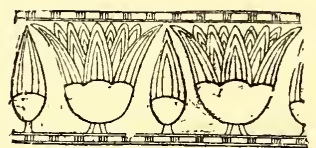

Fig. 95 .

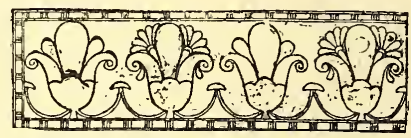

Fig. 96.

either kneel, or advance in majestic procession, along the ground level. These are the nomes, lakes, and dis-

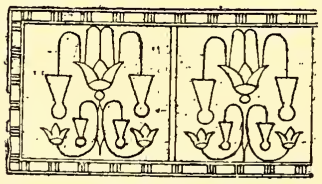

Fig. 97 .

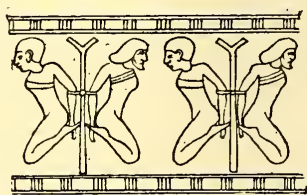

Fig. 98.

tricts of Egypt, bringing offerings of their products to the god. In one instance, at Karnak, Thothmes III. caused the fruits, flowers, and animals indigenous to the foreign lands which he had conquered, to be sculp- 
tured on the lower courses of his walls (fig. I00). The ceilings were painted blue, and sprinkled with five-pointed stars painted yellow, occasionally interspersed with the cartouches of the royal founder. The monotony of this Egyptian heaven was also relieved by long bands of hieroglyphic inscriptions. The vultures of Nekheb and Uati, the goddesses of the south and north, crowned and armed with divine emblems (fig. IOI), hovered above the central nave of

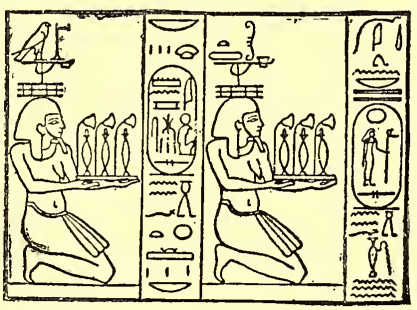

Fig. 99 . the hypostyle halls, and on the under side of the lintels of the great doors, above the head of the king as he

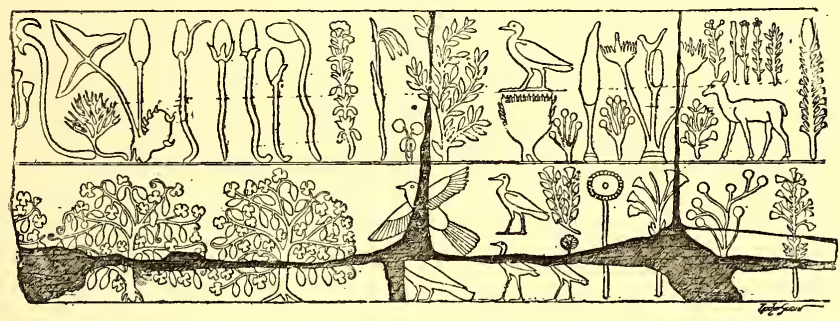

Fig. Ioo.

passed through on his way to the sanctuary. At the Ramesseum, at Edfoo, at Philæ, at Denderah, at Ombos, at Esneh, the depths of the firmament seemed to open to the eyes of the faithful, revealing the dwellers therein. There the celestial ocean poured forth its floods, navigated by the sun and moon, with 
their attendant escort of planets, constellations, and decans; and there also the genii of the months and days marched in long procession. In the Ptolemaic age, zodiacs fashioned after Greek models were sculptured side by side with astronomical tables of purely native

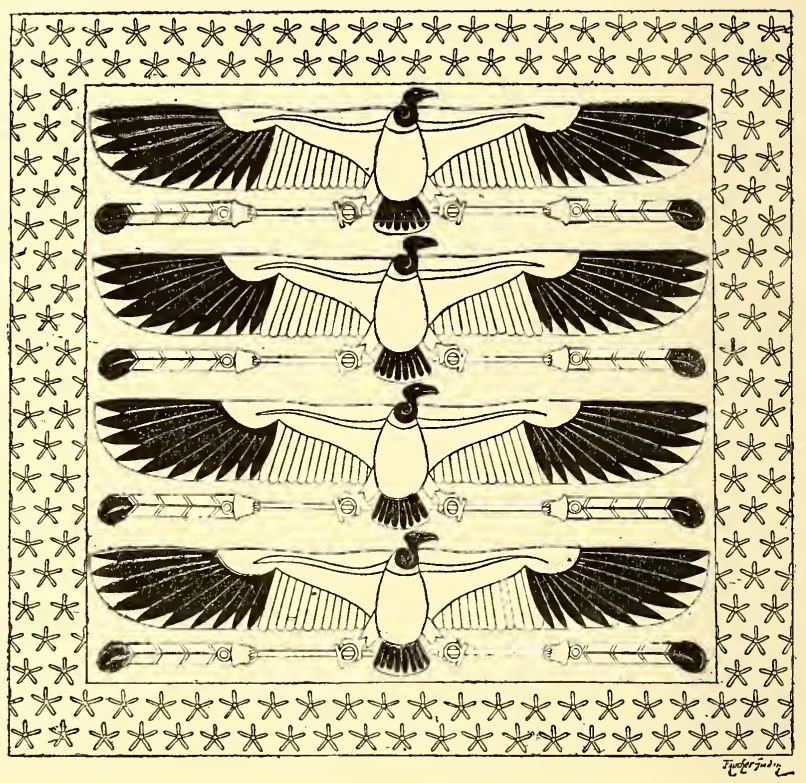

Fig. IOI.

origin (fig. IO2). The decoration of the architraves which supported the massive roofing slabs was entirely independent of that of the ceiling itself. On these were wrought nothing save boldly cut inscriptions, in which the beauty of the temple, the names of the builderkings who had erected it, and the glory of the gods to 
whom it was consecrated, are emphatically celebrated. Finally, the decoration of the lowest part of the walls and of the ceiling was restricted to a small number of subjects, which were always similar: the most im-

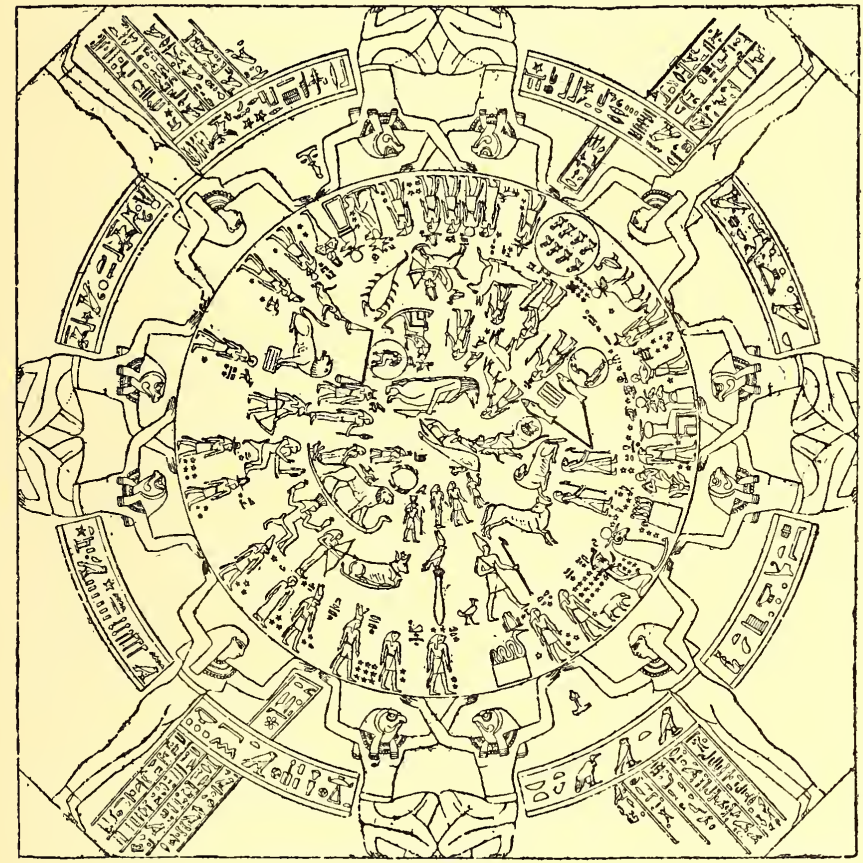

Fig. I02.-Zodiacal circle of Denderah.

portant and varied scenes being suspended, as it were, between earth and heaven, on the sides of the chambers and the pylons.

These scenes illustrate the official relations which subsisted between Egypt and the gods. The people had 
no right of direct intercourse with the deities. They needed a mediator, who, partaking of both human and divine nature, was qualified to communicate with both. The king alone, Son of the Sun, was of sufficiently high descent to contemplate the god in his temple, to serve him, and to speak with him face to face. Sacrifices could be offered only by him, or through him, and in his name. Even the customary offerings to the dead were conventionally supposed to pass through his hands, and the family availed themselves of his name (suten ta hotep) to forward them to the other world. The king is seen, therefore, in all parts of the temple, standing, seated, kneeling, slaying the victim, presenting the parts, pouring out the wine, the milk, and the oil, and burning the incense. All humankind acts through him, and through him performs its duty towards the gods. When the ceremonies to be performed needed the assistance of many persons, then alone do mortal subordinates (consisting, as much as possible, of his own family) appear by his side. The queen, standing behind him like Isis behind Osiris, uplifts her hand to protect him, shakes the sistrum, beats the tambourine to dispel evil spirits, or holds the libation vase or bouquet. The eldest son carries the net or lassoes the bull, and recites the prayer while his father successively presents to the god each object prescribed by the ritual. A priest may occasionally act as substitute for the prince, but other men perform only the most nienial offices. They are slaughterers or servants, or they bear the boat or canopy of the god. The god, for his part, is not always alone. He has his wife and his son by his side; next after them the gods of the neighbouring 
nomes, and, in a general way, all the gods of Egypt. From the moment that the temple is regarded as representing the world, it must, like the world, contain all gods, both great and small. They are most frequently ranged behind the principal god, seated or standing; and with him they share in the homage paid by the king. Sometimes, however, they take an active part in the ceremonies. The spirits of On and Khonu kneel before the sun, and proclaim his praise. Hor, Set, or Thoth conduct Pharaoh into the presence of his father Amen$\mathrm{Ra}$, or perform the functions elsewhere assigned to the prince or the priest. They help him to overthrow the victim or to snare birds for the sacrifice; and in order to wash away his impurities, they pour upon his head the waters of youth and life. The position and functions of these co-operating gods were strictly defined in the theology. The sun, travelling from east to west, divided the universe into two worlds, the world of the north and the world of the south. The temple, like the universe, was double, and an imaginary line passing through the axis of the sanctuary divided it into two temples-the temple of the south on the right hand, and the temple of the north on the left. The gods and their various manifestations were divided between these two temples, according as they belonged to the northern or southern hemisphere. This fiction of duality was carried yet further. Each chamber was divided, in imitation of the temple, into two halves, the right half belonging to the south, and the left half to the north. The royal homage, to be complete, must be rendered in the temples of the south and of the north, and to the gods of the south and of the north, 
and with the products of the south and the north. Each sculptured tableau must, therefore, be repeated at least twice in each temple-on a right wall and on a left wall. Amen, on the right, receives the corn, the wine, the liquids of the south; while on the left he receives the corn, the wine, and the liquids of the north. As with Amen, so with Maut, Khonsu, Mentu, and many other gods. Want of space frequently frustrated the due execution of this scheme, and we often meet with a tableau in which the products of north and south together are placed before an Amen, who represents both Amen of the south and Amen of the north. These

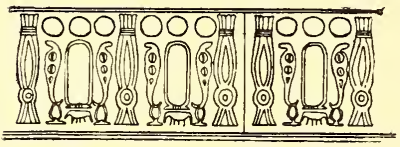

Fig. 103. departures from decorative usage are, however, exceptional, and the dual symmetry is always observed where space permits.

In Pharaonic times, the tableaux were not overcrowded. The wall-surface intended to be covered was marked off below by a line carried just above the ground level decoration, and was bounded above by the usual cornice, or by a frieze. This frieze might be composed of uræi, or of bunches of lotus; or of royal cartouches (fig. 103) supported on either side by divine symbols; or of emblems borrowed from the local cult (by heads of Hathor, for instance, in a temple dedicated to Hathor); or of a horizontal line of dedicatory inscription engraved in large and deeply-cut hieroglyphs. The wall space thus framed in contained sometimes a single scene, and sometimes two scenes, one above the other. The wall must be very lofty if this number is ex- 
ceeded. Figures and inscriptions were widely spaced, and the scenes succeeded one another with scarcely a break. The spectator had to discover for himself where they began or ended. The head of the king was always studied from the life, and the faces of the gods reproduced the royal portrait as closely as possible. As Pharaoh was the son of the gods, the surest way to obtain portraits of the gods was to model their faces after the face of the king. The secondary figures were noless carefully wrought; but when these were very numerous, they were arranged on two or three levels, the total height of which never exceeded that of the principal personages. The offerings, the sceptres, the jewels, the vestments, the head-dresses, and all the accessories were treated with a genuine feeling for elegance and truth. The colours, moreover, were so combined as to produce in each tableau the effect of one general and prevailing tone; so that in many temples there were chambers which can be justly distinguished as the Blue Hall, the Red Hall, or the Golden Hall. So much for the classical period of decoration.

As we come down to later times, these tableaux are multiplied, and under the Greeks and Romans they become so numerous that the smallest wall contained not less than four (fig. I04), five, six, or even eight registers. The principal figures are, as it were, compressed, so as to occupy less room, and all the intermediate space is crowded with thousands of tiny hieroglyphs. The gods and kings are no longer portraits of the reigning sovereign, but mere conventional types without vigour or life. As for the secondary figures and acces- 
sories, the sculptor's only care is to crowd in as many

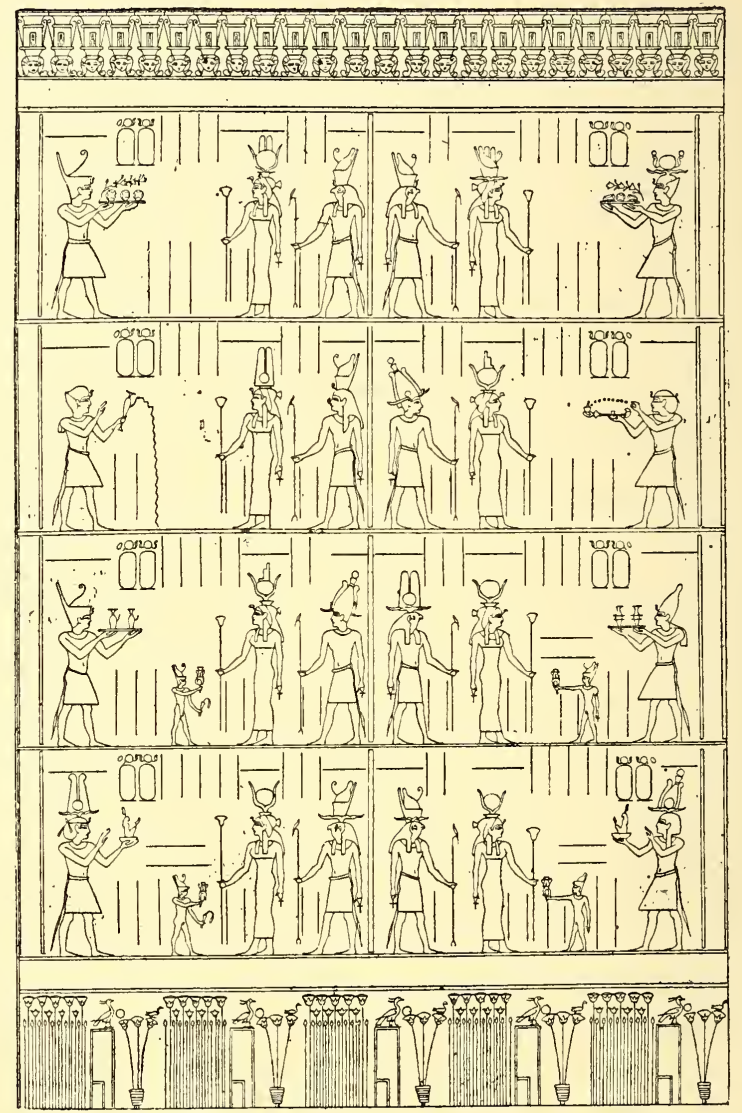

Fig. 104.-Wall of a chamber at Denderah, to show the arrangement of the tableaux.

as possible. This was not due to a defect of taste, but to the prevalence of a religious idea which decided and 
enforced these changes. The object of decoration was not merely the delight of the eye. Applied to a piece of furniture, a coffin, a house, a temple, decoration possessed a certain magical property, of which the power and nature were determined by each being or action represented, by each word inscribed or spoken, at the moment of consecration. Every subject was, therefore, an amulet as well as an ornament. So long as it endured, it ensured to the god the continuance of homage rendered, or sacrifices offered, by the king. To the king, whether living or dead, it confirmed the favours granted to him by the god in recompense for his piety. It also preserved from destruction the very wall upon which it was depicted. At the time of the Eighteenth Dynasty, it was thought that two or three such amulets sufficed to compass the desired effect; but at a later period it was believed that their number could not be too freely multiplied, and they, therefore, put in as many as the surface would contain. An average chamber of Edfoo or Denderah yields more material for study than the hypostyle hall of Karnak; and the chapel of Antoninus Pius at Philæ, had it been finished, would have contained more scenes than the sanctuary of Luxor and the passages by which it is surrounded.

Observing the variety of subjects treated on the walls of any one temple, one might at first be tempted to think that the decoration does not form a connected whole, and that, although many series of scenes must undoubtedly contain the development of an historic idea or a religious dogma, yet that others are merely strung together without any necessary link. At Luxor, and again at the Ramesseum, each face of the pylon is 
a battle-field on which may be studied, almost day for day, the campaign of Rameses II. against the Kheta, which took place in the fifth year of his reign. 'There we see the Egyptian camp attacked by night; the king's bodyguard surprised during the march; the defeat of the enemy; their flight; the garrison of Kadesh sallying forth to the relief of the vanquished; and the disasters which befel the prince of the Kheta and his generals. Elsewhere, it is not the war which is represented, but the human sacrifices which anciently celebrated the close of each campaign. The king is seen in the act of seizing his prostrate prisoners by the hair of their heads, and uplifting his mace as if about to shatter their heads at a single blow. At Karnak, along the whole length of the outer wall, Seti I. pursues the Bedaween of Sinai. At Medinet Haboo Rameses III. destroys the fleet of the peoples of the great sea, or receives the cut-off hands of the Libyans, which his soldiers bring to him as trophies. In the next scene, all is peace; and we behold Pharaoh pouring out a libation of perfumed water to his father Amen. It would seem as if no link could be established between these subjects, and yet the one is the necessary consequence of the others. If the god had not granted victory to the king, the king in his turn would not have performed these ceremonies in the temple. The sculptor has recorded the events in their order:-first the victory, then the sacrifice. The favour of the god precedes the thank-offering of the king. Thus, on closer examination, we find this multitude of episodes forming the several links of one continuous chain, while every scene, including such as seem at first sight to be wholly 
unexplained, represents one stage in the development of a single action which begins at the door, is carried through the various halls, and penetrates to the farthest recesses of the sanctuary. The king enters the temple. In the courts, he is everywhere confronted by reminiscences of his victories; and here the god comes forth to greet him, hidden in his shrine and surrounded by priests. The rites prescribed for these occasions are graven on the walls of the hypostyle hall in which they were performed. These being over, king and god together take their way to the sanctuary. At the door which leads from the public hall to the mysterious part of the temple, the escort halts. The king crosses the threshold alone, and is welcomed by the gods. He then performs in due order all the sacred ceremonies enjoined by usage. His merits increase by virtue of his prayers; his senses become exalted; he rises to the level of the divine type. Finally he enters the sanctuary, where the god reveals himself unwitnessed, and speaks to him face to face. The sculptures faithfully reproduce the order of this mystic presentation:-the welcoming reception on the part of the god; the acts and offerings of the king; the vestments which he puts on and off in succession; the various crowns which he places on his head. The prayers which he recites and the favours which are conferred upon him are also recorded upon the walls in order of time and place. The king, and the few who accompany him, have their backs towards the entrance and their faces towards the door of the sanctuary. The gods, on the contrary, or at least such as do not make part of the procession, face the entrance, and have their backs turned towards the sanctuary. If 
during the ceremony the royal memory failed, the king

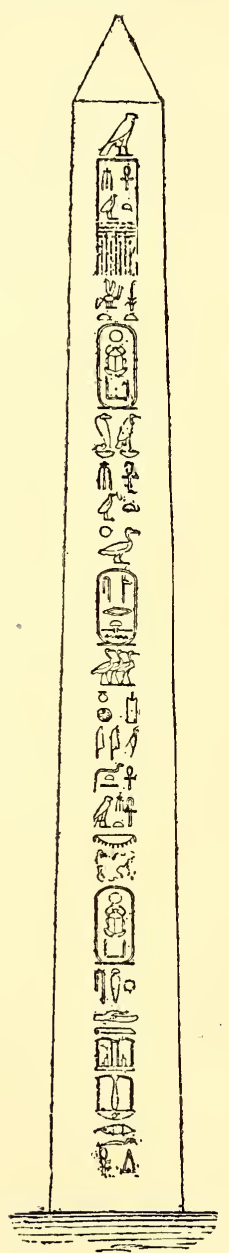

Fig. 105. needed but to raise his eyes to the wall, whereon his duties were mapped out for him.

Nor was this all. Each part of the temple had its accessory decoration and its furniture. The outer faces of the pylons were ornamented, not only with the masts and streamers before mentioned, but with statues and obelisks. The statues, four or six in number, were of limestone, granite, or sandstone. They invariably represented the royal founder, and were sometimes of prodigious size. The two Memnons seated at the entrance of the temple of Amenhotep III., at Thebes, measured about fifty feet in height. The colossal Rameses II. of the Ramesseum measured fifty-seven feet, and that of Tanis at least seventy feet. The greater number, however, did not exceed twenty feet. They mounted guard before the temple, facing outwards, as if confronting an approaching enemy. The obelisks of Karnak are mostly hidden amid the central courts; and those of Queen Hatshepsu were imbedded for seventeen feet of their height in masses of masonry which concealed their bases. These are 
accidental circumstances, and easy of explanation. Each of the pylons before which they are stationed had in its turn been the façade of the temple, and was thrown into the rear by the works of succeeding Pharaohs. The true place of all obelisks was in front of the colossi, on each side of the main entrance.* They are always in pairs, but often of unequal height. Some have professed to see in them the emblem of Amen, the Generator ; or a finger of the god; or a ray of the sun. In sober truth, they are a more shapely form of the standing stone, or menhir, which is raised by semi-civilised peoples in commemoration of their gods or their dead. Small obelisks, about three feet in height, are found in tombs as early as the Fourth Dynasty. 'They are placed to right and left of the stela; that is to say, on either side of the door which leads to the dwelling of the dead. Erected before the pylon-gates of temples, they are made of granite, and their dimensions are considerable. The obelisk of Heliopolis (fig. I05) measures sixty-eight feet in the shaft, and the obelisks of Luxor stand seventy-seven and seventy-five and a half feet high, respectively. The loftiest known is the obelisk of Queen Hatshepsu at Karnak, which rises to a height of Iog feet. To convey such masses, and to place them in equilibrium, was a sufficiently difficult task, and one is at a loss to

* At Tanis there seems to have been a close succession of obelisks and statues along the main avenue leading to the Temple, without the usual corresponding pylons. These were ranged in pairs; i.e., a pair of obelisks, a pair of statues; a pair of obelisks, a pair of shrines; and then a third pair of obelisks. See Tanis, Part I., by 'W. M. F. Petrie, published by the Egypt Exploration Fund, I884. [Translator's note.] 
understand how the Egyptians succeeded in erecting them with no other appliances than ropes and sacks of sand. Queen Hatshepsu boasts that her obelisks were quarried, shaped, transported, and erected in seven months; and we have no reason to doubt the truth of her statement.*

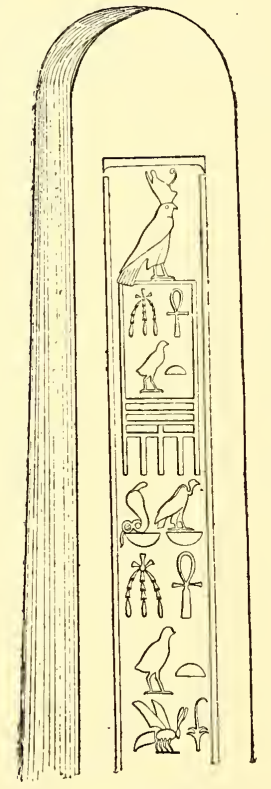

Fig. 106.

Obelisks were almost always square, with the faces slightly convex, and a slight slope from top to bottom. The pedestal was formed of a single square block adorned with inscriptions, or with cynocephali in high relief, adoring the sun. The point was cut as a pyramidion, and sometimes covered with bronze or gilt copper. Scenes of offerings to Ra-Harmakhis, Hor, Tum, or Amen are engraved on the sides of the pyramidion and on the upper part of the prism. The four upright faces are generally decorated with only vertical lines of inscription in praise of the king (Note I I). Such is the usual type of obelisk; but we here and there meet with exceptions. That of Begig in the Fayoom (fig. I06) is in shape a rectangular oblong, with a blunt top. A groove upon it shows that it was surmounted by some emblem in metal, perhaps a hawk, like the obelisk represented on

* This fact is recorded in the hieroglyphic inscription upon the obelisks. [Translator's note.] 
a funereal stela in the Boulak Museum. This form, which like the first is a survival of the menhir, was in vogue till the last days of Egyptian art. It is even found at Axum, in the middle of Ethiopia, dating from about the fourth century of our era, at a time when in Egypt the ancient obelisks were being carried out of the country, and none dreamed of erecting new ones. Such was the accessory decoration of the pylon. The inner courts and hypostyle halls of the temple contained more colossi. Some, placed with their backs against the outer sides of pillars or walls, were half engaged in the masonry, and built up in courses. At Luxor under the peristyle, and at Karnak between each column of the great nave, were also placed statues of Pharaoh; but these were statues of Pharaoh the victor, clad in his robe of state. The right of consecrating a statue in the temple was above all a royal prerogative; yet the king sometimes permitted private persons to dedicate their statues by the side of his own. This was, however, a special favour, and such monuments always bear an inscription stating that it is "by the king's grace" that they occupy that position. Rarely as this privilege was granted, it resulted in a vast accumulation of votive statues, so that in the course of centuries the courts of some temples became crowded with them. At Karnak, the sanctuary enclosure was furnished outside with a kind of broad bench, breast high, like a long base. Upon this the statues were placed, with their backs to the wall. Attached to each was an oblong block of stone, with a projecting spout on one side; these are known as "tables of offerings" (fig. I07). The upper face is more or less hollowed, 
and is often sculptured with bas-relief representations of loaves, joints of beef, libation vases, and other objects usually presented to the dead or to the gods. Those of King Amoni-Entef-Amenemhat, at Boulak, are blocks of red granite more than three feet in length, the top of which is hollowed out in regular rows of cup-holes,

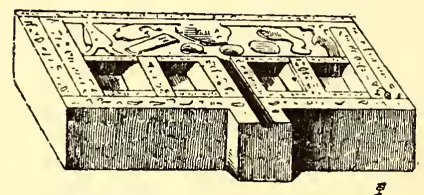

Fig. 107. each cup-hole being reserved for one particular offering. There was, in fact, an established form of worship provided for statues, and these tables were really altars upon which were deposited sacrificial offerings of meat, cakes, fruits, vegetables, and the like.

The sanctuary and the surrounding chambers contained the objects used in the ceremonial of worship. The bases of altars varied in shape, some being square and massive, others polygonal or cylindrical. Some of these last are in form not unlike a small cannon, which is the name given to them by the Arabs. The most ancient are those of the Fifth

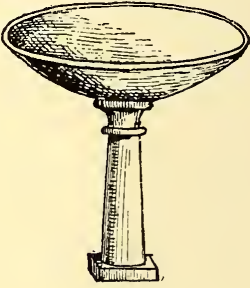

Fig. 108. Dynasty ; the most beautiful is one dedicated by Seti I., now in the Boulak Museum. The only perfect specimen of an altar known to me was discovered at Mensheeyah in I884 (fig. 108). It is of white limestone, hard and polished like marble. It stands upon a pedestal in the form of a long cone, having no other ornament than a torus about half an inch below the top. Upon this 
pedestal, in a hollow specially prepared for its reception, stands a large hemispherical basin. The shrines are little chapels of wood or stone (fig. I09), in which the spirit of the deity was supposed at all times to dwell, and which, on ceremonial occasions, contained his image. The sacred barks were built after the model of the Bari, or boat, in which the sun per-

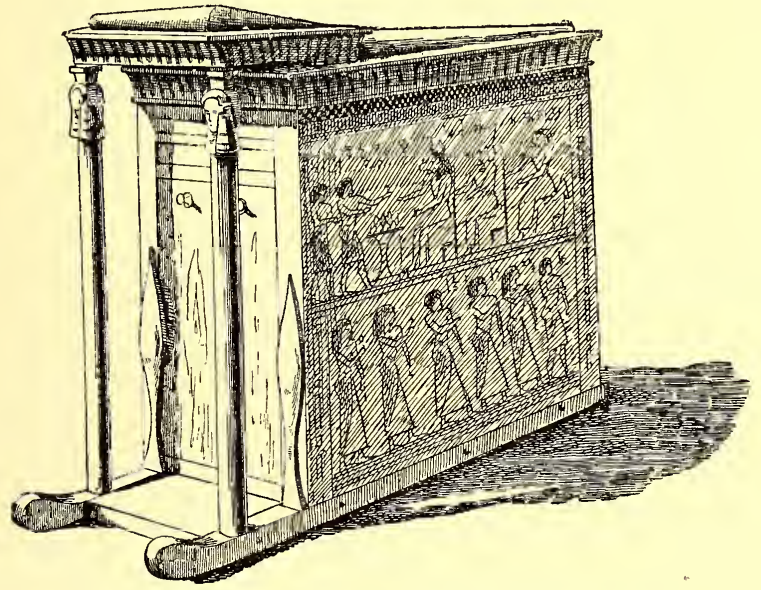

Fig. 109.- Naos of wood in the Museum at Turin.

formed his daily course. The shrine was placed amidship of the boat, and covered with a veil, or curtain, to conceal its contents from all spectators. The crew were also represented, each god being at his post of duty, the pilot at the helm, the look-out at the prow, the king upon his knees before the door of the shrine. We have not as yet discovered any of the statues employed in the ceremonial, but we know what 
they were like, what part they played, and of what materials they were made. They were animated, and in addition to their bodies of stone, metal, or wood, they had each a soul magically derived from the soul of the divinity which they represented. They spoke, moved, acted-not metaphorically, but actually. The later Ramessides ventured upon no enterprises without consulting them. They stated their difficulties, and the god replied to each question by a movement of the head. According to the Stela of Bakhtan,* a statue of Khonsu places its hands four times on the nape of the neck of another statue, so transmitting the power of expelling demons. It was after a conversation with the statue of Amen in the dusk of the sanctuary, that Queen Hatshepsu despatched her squadron to the shores of the Land of Incense. $\dagger$ Theoretically, the divine soul

* This celebrated tablet, preserved in the Bibliothèque Nationale, Paris, has been frequently translated, and is the subject of a valuable treatise by the late Vicomte de Rougé. It was considered authentic till Dr. Ermann, in an admirable paper contributed to the Zeitschrift, I 883 , showed it to have been a forgery concocted by the priests of Khonsu during the Twentieth Dynasty. (See Maspero's Hist. Ancienne des Peuples de l'Orient, chap. vi., pp. 287, 8. Fourth Edition. See also Sir Erasmus Wilson's Egypt of the Past, chap. vii.) [Translator's note.]

$\dagger$ The Land of Incense, called also in the inscriptions "The Land of Punt," was the country from which the Egyptians imported spices, precious woods, gums, etc. It is supposed to represent that part of the African coast south of Abyssinia, which lies between Bab-elMandeb and Cape Guardafui. Queen Hatshepsu's famous expedition is represented in a series of coloured bas-relief sculptures on the walls of her great temple at Dayr-el-Baharee, all of which are reproduced in Dr. Dümichen's great work, The Fleet of an Egyptian Queen. For a full account of this temple, its decoration, and the expedition of Hatshepsu, see Sir Erasmus Wilson's Egypt of the Past, chap. vi. [Translator's note.] 
of the image was understood to be the only miracle worker; practically, its speech and motion were the results of a pious fraud. Interminable avenues of sphinxes, gigantic obelisks, massive pylons, halls of a hundred columns, mysterious chambers of perpetual night-in a word, the whole Egyptian temple and its dependencies - were built by way of a hiding-place for a performing puppet, of which the wires were worked by a priest. 


\section{CHAPTER III.}

TOMBS.

THE Egyptians regarded man as composed of various different entities, each having its separate life and functions. First, there was the body ; then the $K a$, or double, which was a less solid duplicate of the corporeal form-a coloured but ethereal projection of the individual, reproducing him feature for feature. The double of a child was as a child; the double of a woman was as a woman; the double of a man was as a man. After the double $(K a)$ came the Soul $(B i$ or $B a$ ), which was popularly imagined and represented as a bird; after the Soul came the "Khoo," or "the Luminous," a spark from the fire divine. None of these elements were in their own nature imperishable. Left to themselves, they would hasten to dissolution, and the man would thus die a second time; that is to say, he would be annihilated. The piety of the survivors found means, however, to avert this catastrophe. By the process of embalmment, they could for ages suspend the decomposition of the body ; while by means of prayer and offerings, they saved the Double, the Soul, and the "Luminous" from the second death, and secured to them all that was necessary for the prolongation of their existence. The Double never left the place where the mummy reposed; but the Soul and 
the "Khoo" went forth to follow the gods. They, however, kept perpetually returning, like travellers who come home after an absence. The tomb was therefore a dwelling-house, the "Eternal House" of the dead, compared with which the houses of the living were but wayside inns; and these Eternal Houses were built after a plan which exactly corresponded to the Egyptian idea of the after-life. The Eternal House must always include the private rooms of the Soul, which were closed on the day of burial, and which no living being could enter without being guilty of sacrilege. It must also contain the reception rooms of the Double, where priests and friends brought their wishes or their offerings; the two being connected by a passage* of more or less length. The arrangement of these three parts varied according to the period, the place, the nature of the ground, and the caprice of each person. The rooms accessible to the living were frequently built above ground, and formed a separate edifice. Sometimes they were excavated in the mountain side, as well as the tomb itself. Sometimes, again, the vault where the mummy lay hidden, and the passages leading to that vault, were in one place, while the place of prayer and offering stood far off in the plain. But whatever variety there may be found as to detail and arrangement, the principle is always the same. The tomb is a dwelling, and it is constructed in such wise as may best promote the well-being, and ensure the preservation, of the dead.

* These three parts are (I) the chapel, (2) the passage, or shaft, (3) the sepulchral vault. If the latter was below the level of the chapel, as in the time of the Ancient Empire, the communication was by a sloping or vertical shaft. [Translator's note.] 


\section{I.-MAstabas.}

The most ancient monumental tombs are found in the necropolis of Memphis, between Aboo Roash and Dashoor,* and belong to the Mastaba type (Note I2). The mastaba (fig. I IO) is a quadrangular building, which from a distance might be taken for a truncated pyramid. Many mastabas are from 30 to 40 feet in height, I 50 feet in length, and 80 feet in width; while others do not exceed Io feet in height or 15 feet in length. The faces are symmetrically inclined and generally smooth, though sometimes the courses retreat like steps.

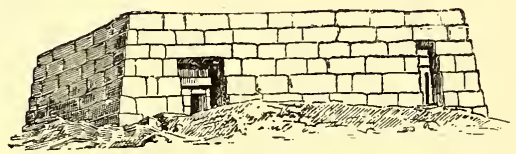

Fig. I Io.

The materials employed are stone or brick. The stone is always limestone, cut in blocks about two and a half feet

long, two feet high, and twenty inches thick. Three sorts of limestone were employed: for the best tombs, the fine white limestone of Toorah, or the compact siliceous limestone of Sakkarah; for ordinary tombs, the marly limestone of the Libyan hills. This last, impregnated with salt and veined with crystalline gypsum, is a friable material, and unsuited for ornamentation. The bricks are of two kinds, both being merely sun-dried. The most ancient kind, which ceased to be used about the time of the Sixth Dynasty, is small ( $8.7 \times 4.3 \times 5.5$ inches), yellowish, and made of nothing but sand, mixed with a little clay and grit.

* I adhere to the spelling of "Murray's Handbook," for the reasons given in the Preface; but the correct transliteration of this name is Dahshoor. [Translator's note.] 
The later kind is of mud mixed with straw, black, compact, carefully moulded, and of a fair size $\left(15^{\circ} \mathrm{O} \times 7^{\circ} \mathrm{I}\right.$ $\times 5.5$ inches). 'The style of the internal construction differs according to the material employed by the architect. In nine cases out of ten, the stone mastabas are but outwardly regular in construction. The core is of roughly quarried rubble, mixed with rubbish and limestone fragments hastily bedded in layers of mud, or piled up without any kind of mortar. The brick mastabas are nearly always of homogeneous construction. The facing bricks are carefully mortared, and the joints inside are filled up with sand. That the mastaba should be canonically oriented, the four faces set to the four cardinal points, and the longer axis laid from north and south, was indispensable; but, practically, the masons took no special care about finding the true north, and the orientation of these structures is seldom exact. At Gizeh, the mastabas are distributed according to a symmetrical plan, and ranged in regular streets. At Sakkarah, at Abooseer, and at Dashoor, they are scattered irregularly over the surface of the plateau, crowded in some places, and wide apart in others. The Mussulman cemetery at Siout perpetuates the like arrangement, and enables us to this day to realise the aspect of the Memphite necropolis towards the close of the ancient empire.

A flat, unpaved platform, formed by the top course of the core (Note I3), covers the top of the mass of masonry. This platform is scattered over with terracotta vases, nearly buried in the loose rubbish. These lie thickly over the hollow interior, but are more sparsely deposited elsewhere. The walls are bare. The doors 
face to the eastward side. They occasionally face towards the north or south side, but never towards the west. In theory, there should be two doors, one for the dead, the other for the living. In practice, the entrance for the dead was a mere niche, high and narrow, cut in the eastward face, near the north-east corner. At the back of this niche are marked vertical lines, framing in a closed space. Even this imitation of a door was sometimes

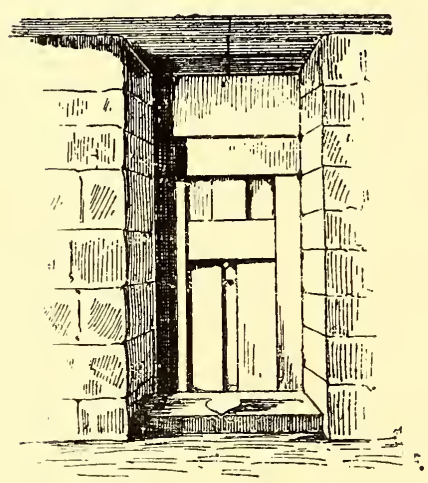

Fig. I I I.

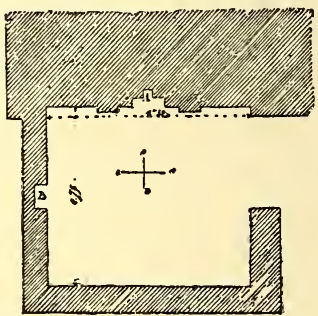

Fig. II 2.

might. The door of the living was made more or less important, according to the greater or less development of the chamber to which it led. The chamber and door are in some cases represented by only a shallow recess decorated with a stela and a table of offerings (fig. I I I). This is sometimes protected by a wall which projects from the façade, thus forming a kind of forecourt open to the north. The forecourt is square in the tomb of Kaāpir (fig. I I 2), and irregular in that of Neferhotep at Sakkarah (fig. 
I 13). When the plan includes one or more chambers, the door sometimes opens in the middle of a small architectural façade (fig. I I4), or under a little portico supported by two square pillars without either base or abacus (fig. I I 5). 。 The doorway is very simple, the two jambs being ornamented with

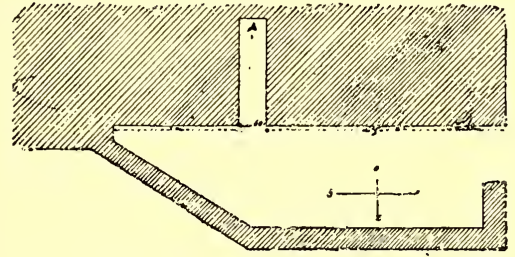

Fig. I 13. bas-reliefs representing the deceased, and surmounted

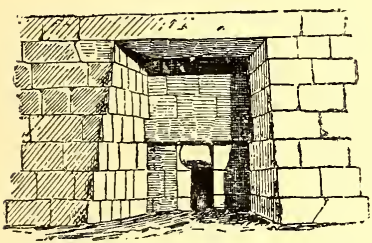

Fig. I I4. by a cylindrical drum engraved with his name and titles. In the tomb of Pohounika at Sakkarah the jambs are two pilasters, each crowned with two lotus flowers; but this example is, so far, unique.

The chapel was usually small, and lost in the mass of the building (fig. I 6), but no precise rule determined its size. In the tomb of $\mathrm{Ti}$ there is first a portico (A), then a square ante-chamber with pillars (B), then a passage (c) with a small

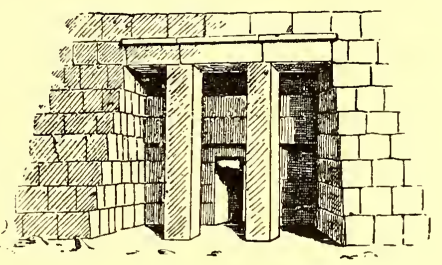

Fig. I I 5 . room (D) on the right, leading to the last chamber (E) (fig. II7). There was room enough in this tomb for many persons, and, in point of fact, the wife of $\mathrm{Ti}$ 
reposed by the side of her husband. When the monument belonged to only one person, the structure was less complicated. A short and narrow passage

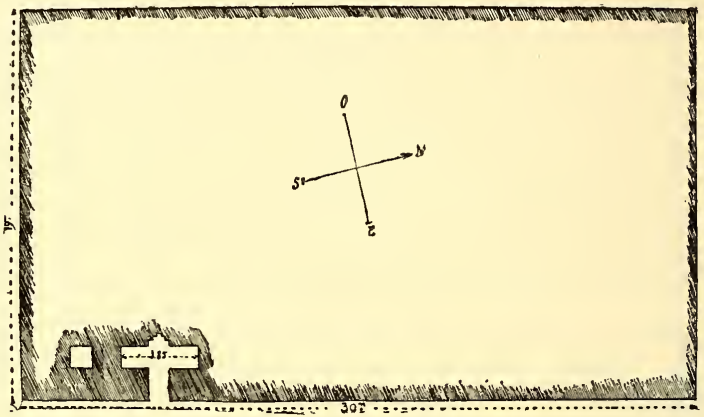

Fig. I 16.

led to an oblong chamber upon which it opened at right angles, so that the place is in shape of a $\mathrm{T}$ (fig. I I8). The end wall is generally smooth; but

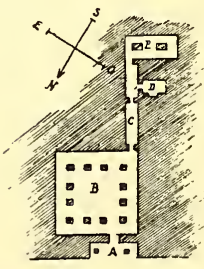

Fig. I 17 .

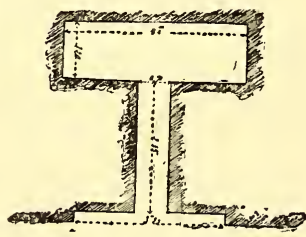

Fig. 118 .

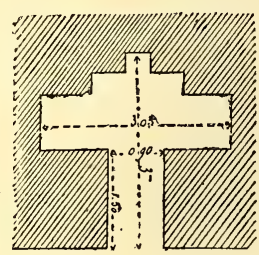

Fig. I 19.

sometimes it is recessed just opposite the entrance passage, and then the plan forms a cross, of which the head is longer or shorter (fig. I I9). This was the ordinary arrangement, but the architect was free to reject it, if he so pleased. Here, a chapel consists of two parallel lobbies connected by a cross passage 
(fig. I 20). Elsewhere, the chamber opens from a corner of the passage (fig. I2I). Again, in the tomb of Ptahhotep, the site was hemmed in by older buildings, and was not large enough. The builders therefore joined the new mastaba to the older one in such wise as to give them one entrance in common, and thus the chapel of the one is enlarged by absorbing the whole of the space occupied by the other (fig. I 22).

The chapel was the re-

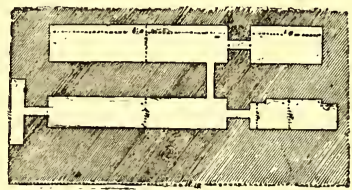

Fig. 120. ception room of the Double. It was there that the relations, friends, and priests celebrated the funerary sacrifices on the days prescribed by law; that is to say, "at the feasts of the commencement of the

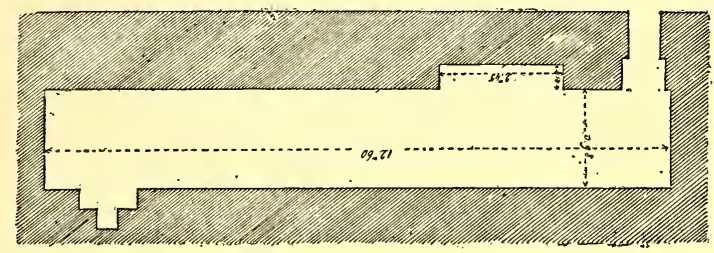

Fig. I2I.

seasons; at the feast of Thoth on the first day of the year; at the feast of Uaga; at the great feast of Sothis; on the day of the procession of the god Min; at the feast of shew-bread; at the feasts of the months and the half months, and the days of the week." They placed the offering in the principal room, at the foot of the west wall, at the exact spot leading to the 
entrance of the "eternal home" of the dead. Unlike the Kiblah of the mosques, or Mussulman oratories, this point is not always oriented towards the same quarter of the compass. It is often found to the west, but that position was not prescribed by rule. In the earliest times it was indicated by a real door, low and narrow, framed and decorated like the door of an ordinary

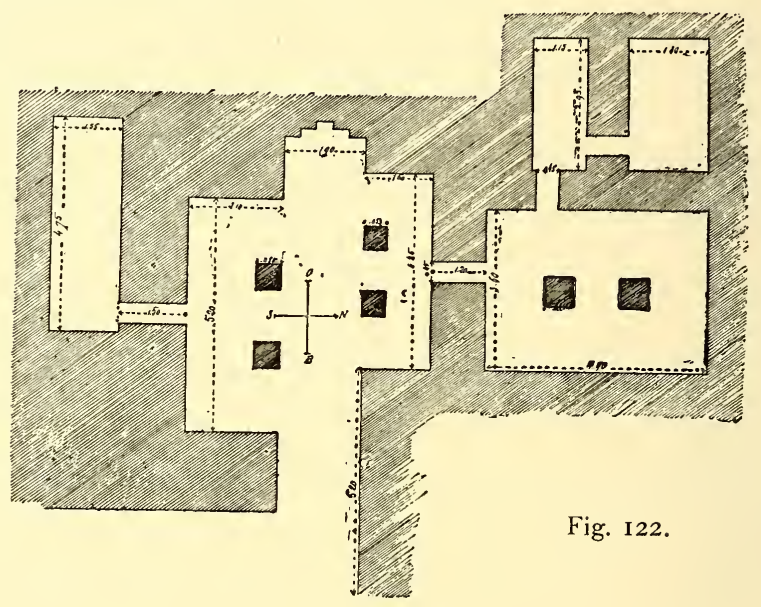

house, but not pierced through. An inscription graven upon the lintel in large readable characters, commemorated the name and rank of the owner. His portrait, either sitting or standing, was carved upon the jambs; and a scene, sculptured or painted on the space above the door, represented him seated before a small round table, stretching out his hand towards the repast placed upon it. A flat slab, or offering table, built into the floor between the two uprights of the doorway, received 
the votive meats and drinks. The living having taken their departure, the Double was supposed to come out

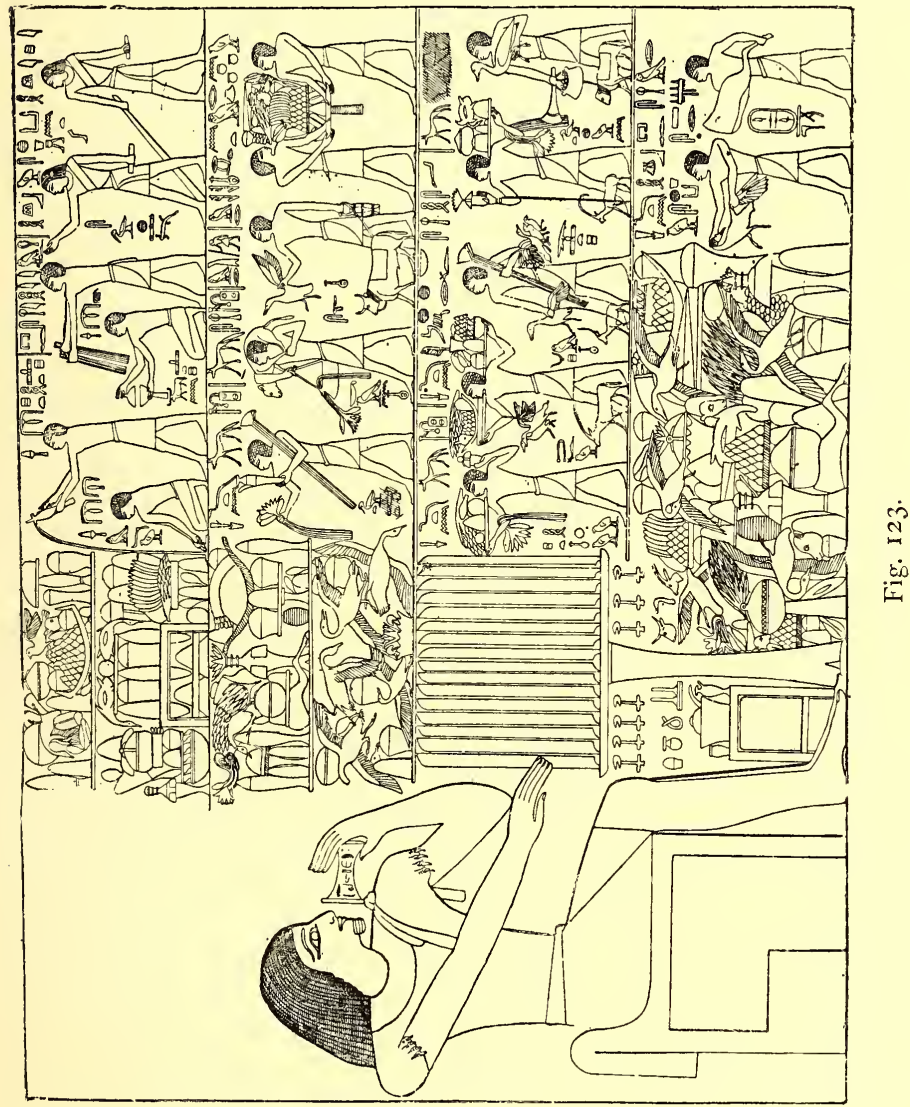

of his house and feed. In principle, this ceremony was bound to be renewed year by year, till the end of time; but the Egyptians ere long discovered that this could 
not be. After two or three generations, the dead of former days were neglected for the benefit of those more recently departed. Even when a pious foundation was established, with a revenue payable for the expenses of the funerary repast and of the priests whose duty it was to prepare it, the evil hour of oblivion was put off for only a little longer. Sooner or later, there came a time when the Double was reduced to seek his food among the town refuse, and amid the ignoble and corrupt filth which lay rejected on the ground. Then, in order that the offerings consecrated on the day of burial might for ever preserve their virtues, the survivors conceived the idea of drawing and describing them on the walls of the chapel (fig. I23). The painted or sculptured reproduction of persons and things ensured the reality of those persons and things for the benefit of the one on whose account they were executed. Thus the Double saw himself depicted upon the walls in the act of eating and drinking, and he ate and drank. This notion once accepted, the theologians and artists carried it out to the fullest extent. Not content with offering mere pictured provisions, they added thereto the semblance of the domains which produced them, together with the counterfeit presentment of the herds, workmen, and slaves belonging to the same. Was a supply of meat required to last for eternity? It was enough, no doubt, to represent the several parts of an ox or a gazelle-the shoulder, the leg, the ribs, the breast, the heart, the liver, the head, properly prepared for the spit; but it was equally easy to retrace the whole history of the animal-its birth, its life in the pasture-lands, its 
slaughter, the cutting up of the carcass, and the presentation of the joints. So also as regarded the cakes and

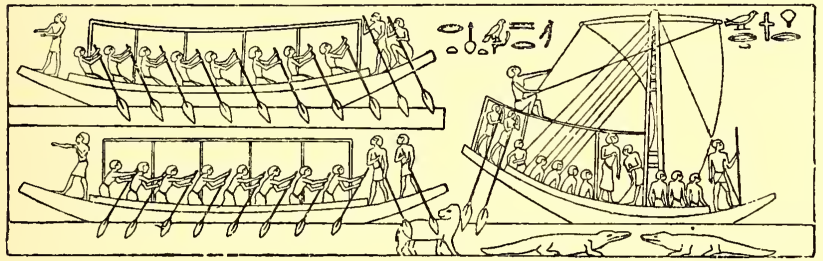

Fig. 124.

bread-offerings, there was no reason why the whole process of tillage, harvesting, corn-threshing, storage, and

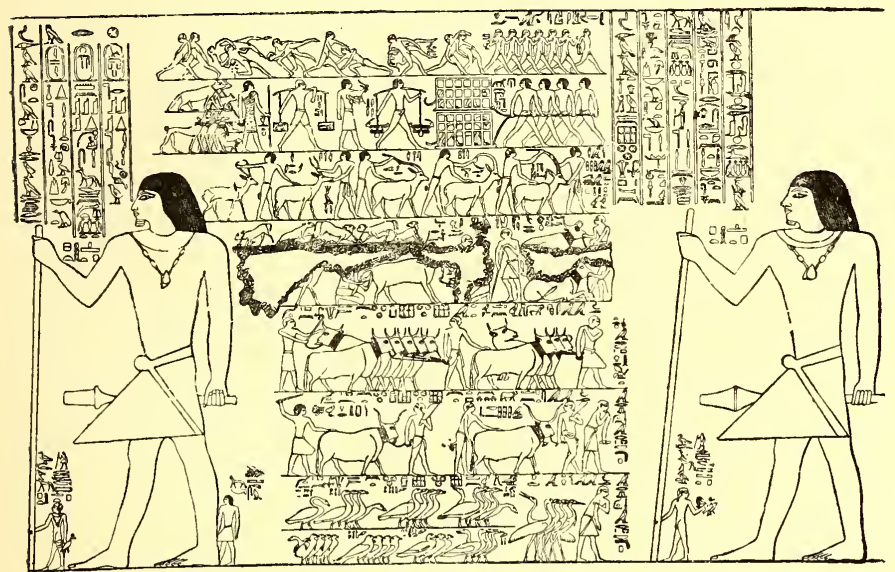

Fig. 125 .

dough-kneading should not be rehearsed. Clothing, ornaments, and furniture served in like manner as a pretext for the introduction of spinners, weavers goldsmiths, and cabinet-makers. The master is of 
superhuman proportions, and towers above his people and his cattle. Some prophetic tableaux show him in his funeral bark, speeding before the wind with all sail set, having started on his way to the next world the very day that he takes possession of his new abode (fig. I24). Elsewhere, we see him as actively superintending his imaginary vassals as formerly he superintended his vassals of flesh and blood. Varied and irregular as they may appear, these scenes are not placed at random upon the walls. They all converge towards that semblance of a

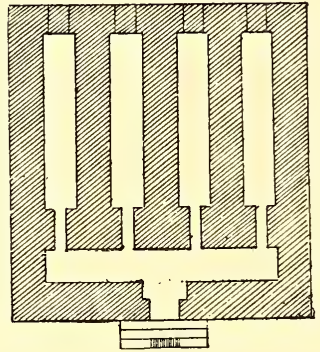

Fig. 126. door which was supposed to communicate with the interior of the tomb. Those nearest to the door represent the sacrifice and the offering; the earlier stages of preparation and preliminary work being depicted in retrograde order as that door is left farther and farther behind. At the door itself, the figure of the master seems to await his visitors and bid them welcome.

The details are of infinite variety. The inscriptions run to a less or greater length according to the caprice of the scribe; the false door loses its architectonic character, and is frequently replaced by a mere stela engraved with the name and rank of the master; yet, whether large or small, whether richly decorated or not decorated at all, the chapel is always the dining-room-or, rather, the larder - to which the dead man has access when he feels hungry. 
On the other side of the wall was constructed a hiding-place in the form of either a high and narrow cell, or a passage without outlet. To this hiding-place archæologists have given the Arab name of "serdab." Most mastabas contain but one ; others contain three or four (fig. I26). These serdabs communicated neither with each other nor with the chapel; and are, as it were, buried in the masonry (fig. I27). If connected at all with the outer world, it is by means of an aperture in the wall about as high up as a man's head (fig. I28), and so small that the hand can with difficulty pass

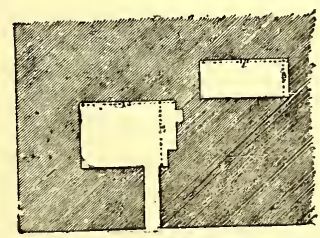

Fig. 127 .

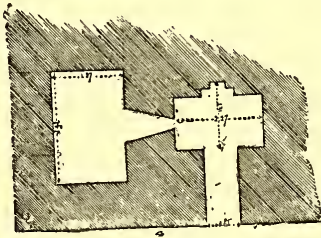

Fig. 128 .

through it. To this orifice came the priests, with murmured prayers and perfumes of incense. Within lurked the Double, ready to profit by these memorial rites, or to accept them through the medium of his statues. As when he lived upon earth, the man needed a body in which to exist. His corpse, disfigured by the process of embalmment, bore but a distant resemblance to its former self. The mummy, again, was destructible, and might easily be burned, dismembered, scattered to the winds. Once it had disappeared, what was to become of the Double? The portrait statues walled up inside the scrdab became, when consecrated, the stone, or wooden, bodies of the defunct. The pious care of his 
relatives multiplied these bodies, and consequentiy multiplied the supports of the Double. A single body represented a single chance of existence for the Double; twenty bodies represented twenty such chances. For the same reason, statues also of his wife, his children, and his servants were placed with the statues of the deceased, the servants being modelled in the act of performing their domestic duties, such as grinding corn, kneading dough, and applying a coat of pitch to the inside surfaces of wine-jars. As for the figures which were merely painted on the walls of the chapel, they detached themselves, and assumed material bodies inside the serdab. Notwithstanding these precautions, all possible means were taken to guard the remains of the fleshly body from natural decay and the depredations of the spoiler. In the tomb of Ti, an inclined passage, starting from the middle of the first hall, leads from the upper world to the sepulchral vault; but this is almost a solitary exception. Generally, the vault is reached by way of a vertical shaft constructed in the centre of the platform (fig. I29), or, more rarely, in a corner of the chapel. The depth of this shaft varies from Io to IOO feet. It is carried down through the masonry; it pierces the rock; and at the bottom, a low passage, in which it is not possible to walk upright, leads in a southward direction to the vault. There sleeps the mummy in a massive sarcophagus of limestone, red granite, or basalt. Sometimes, though rarely, the sarcophagus bears the name and titles of the deceased. Still more rarely, it is decorated with ornamental sculpture. Some examples are known which reproduce the architectural decoration of an 
Egyptian house, with its doors and windows.* The furniture of the vault is of the simplest character,some alabaster perfume vases; a few cups into which the priest had poured drops of the various libation liquids offered to the dead; some large red pottery jars for water ; a head-rest of wood or alabaster ; a scribe's votive palette. Having laid the mummy in the sarcophagus and cemented the lid, the workmen strewed the floor of the vault with the quarters of oxen and gazelles which had just been sacrificed. They next carefully walled up the entrance into the passage, and filled the shaft to the top with a mixture of sand, earth, and stone chips. Being profusely watered, this mass solidified, and became an almost impenetrable body of concrete. The corpse, left to itself, received no visits now, save from the Soul, which

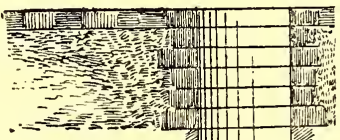
from time to time quitted the celestial regions wherein it voyaged with the gods, and came down to re-unite itself with the body. The funerary vault was the abode of the Soul, as the funerary chapel was the abode of the Double.

Up to the time of the Sixth Dynasty, the walls of

* The sarcophagus of Menkara, unfortunately lost at sea when on its way to England, was of this type. See illustration No. 19, Chapter III., in Sir E. Wilson's Egvpt of the Past. [Translator's note.] 
the vault are left bare. Once only did Mariette find a vault containing half-effaced inscriptions from The Book of the Dead. In I88I, I however discovered some tombs at Sakkarah, in which the vault is decorated in preference to the chapel. These tombs are built with large bricks, a niche and a stela sufficing for the reception of sacrificial offerings. In place of

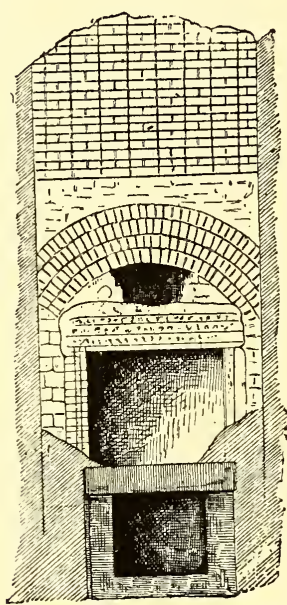

Fig. I3o. the shaft, they contain a small rectangular court, in the western corner of which was placed the sarcophagus. Over the sarcophagus was erected a limestone chamber just as long and as wide as the sarcophagus itself, and about three and a half feet high. This was roofed in with flat slabs. At the end, or in the wall to the right, was a niche, which answered the purpose of a scrdab; and above the flat roof was next constructed an arch of about one foot and a half radius, the space above the arch being filled in with horizontal courses of brickwork up to the level of the platform. The chamber occupies about two-thirds of the cavity, and looks like an oven with the mouth open. Sometimes the stone walls rest on the lid of the sarcophagus, the chamber having evidently been built after the interment had taken place (fig. I30). Generally speaking, however, these walls rest on brick supports, so that the sarcophagus may be opened or closed when 
required. The decoration, which is sometimes painted, sometimes sculptured, is always the same. Each wall was a house stocked with the objects depicted or catalogued upon its surface, and each was, therefore, carefully provided with a fictitious door, through which the Double had access to his goods. On the left wall

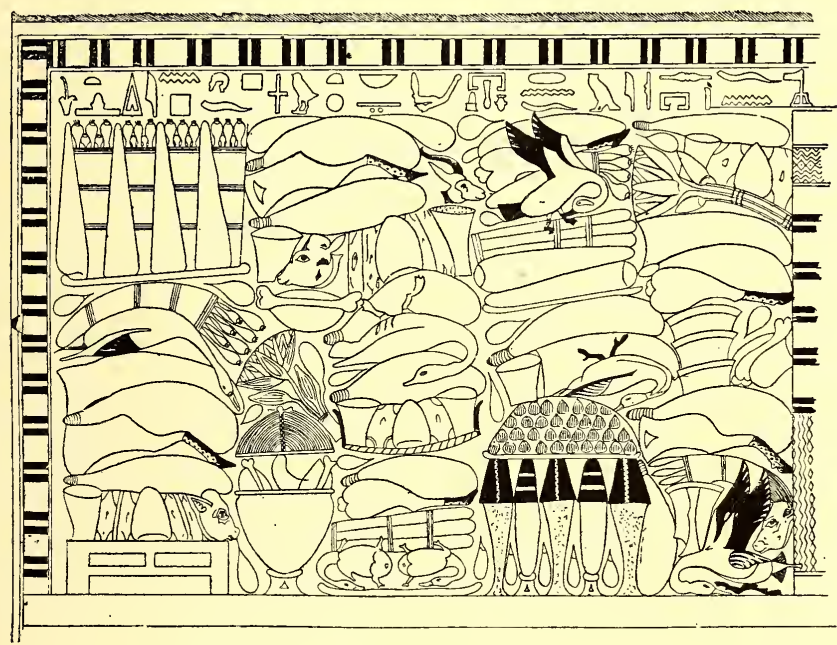

Fig. I3I.

he found a pile of provisions (fig. I3I) ${ }^{*}$ and a table of offerings; on the end wall a store of household utensils, as well as a supply of linen and perfumes, the name and quantity of each being duly registered. These paintings more briefly sum up the scenes de-

* This wall scene is from the tomb of Nenka, near Sakkarah. For a coloured facsimile on a large scale, see Professor Maspero's article entitled "Trois Années de Fouilles," in Mémoires de la Mission Archiologique Française du Caire, P1. 2. I884. [Translator's note.] 
picted in the chapels of ordinary mastabas. Transferred from their original position to the walls of an underground cellar, they were the more surely guaranteed against such possible destruction as might befall them in chambers open to all comers; while upon their preservation depended the length of time during which the dead man would retain possession of the property which they represented.

\section{2.-The Pyramids.}

[For the following translation of this section of Professor Maspero's book I am indebted to the kindness of Mr. W. M. Flinders Petrie, whose work on The Pyramids and Temples of Gizeh, published with the assistance of a grant from the Royal Society in I883, constitutes our standard authority on the subject of the Pyramid-tombs of Ancient Egypt.

I should add that Mr. Petrie's transcriptions of Arab and Egyptian proper names differ from those which I have here employed ; but that, for the sake of uniformity, I have ventured to alter them. Mr. Petrie writes "Khufu" where I write "Khoofoo," "Abusir" for "Abooseer," "Dashur" for "Dashoor," etc., etc. Mr. Petrie's system is doubtless more correct; but for the reasons stated in the preface I have adopted the spelling currently used in books of travel, and by the author of Murray's Handbook for Egypt. Not to cause confusion, Mr. Petrie's notes are given separately at the end of the volume.-A. B. E.]

The royal tombs have the form of pyramids with a square base, and are the equivalent in stone or brick of the tumulus of heaped earth which was piled over the body of the warrior chief in prehistoric times (Note I4). The same ideas prevailed as to the souls of kings as about those of private men; the plan of the pyramid contains, therefore, three parts like the 
mastabas, - the chapel, the passage, and the sepulchral vault.

The chapel is always separate. At Sakkarah no trace of it has been found; it was probably, as later on at Thebes, in a quarter nearer to the town. At Gizeh, Abooseer, and Dashoor, the remains are still to be seen at the east or north fronts of the pyramids. It was a true temple, with chambers, courts, and passages. The fragments of bas-reliefs hitherto found show scenes of sacrifice, and prove that the decoration was the same as in the public halls of the mastabas. The pyramid, properly speaking, contained only the passages and funereal vault. The oldest of which the texts show the existence, north of Abydos, is that of Sneferoo; the latest belong to the princes of the Twelfth Dynasty. The construction of these monuments was, therefore, a continuous work, lasting for thirteen or fourteen centuries, under government direction. Granite, alabaster, and basalt for the sarcophagus and some details were the only materials of which the use and the quantity was not regulated in advance, and which had to be brought from a distance. To obtain them, each king sent one of the great men of his court on a mission to the quarries of Upper Egypt ; and the quickness with which the blocks were brought back was a strong claim upon the sovereign's favour. The remainder was not so costly. If the main work was of brick, they moulded the brick on the spot with earth taken from the foot of the hill. If it was to be of stone, the nearest parts of the plateau provided the common marly limestone in abundance (Note I5). They usually reserved the fine limestone of Toorah 
for the chambers and the casing, and this might be had without even sending specially for it to the opposite side of the Nile; for at Memphis there were stores always full, upon which they continually drew for public buildings, and, therefore, also for the royal tombs. The blocks being taken from these stores, and borne by boats to close below the hill, were raised to their required places along gently sloping causeways. The internal arrangement of the pyramids, the lengths of the passages and their heights, were very variable; the pyramid of Khoofoo rose to 475 feet above the ground, the smallest was not 30 feet high. The difficulty of imagining now what motives determined the Pharaohs to choose such different proportions has led some to think that the mass built was in direct proportion to the time occupied in building; that is to say, to the length of each reign. Thus it was supposed that the king would begin by hastily erecting a pyramid large enough to contain the essential parts of a tomb; and then, year by year, would add fresh layers around the first core, until the time when his death for ever arrested the growth of the monument. But the facts do not justify this hypothesis. The smallest of the pyramids of Sakkarah is that of Unas, who reigned thirty years; but the two imposing pyramids of Gizeh were raised by Khoofoo and Khafra, who continued the one for twenty-four and the other for twenty-three years to govern Egypt. Merenra, who died very young, has a pyramid as large as that of Pepi II., whose reign lasted more than ninety years (Note I6). The plan of each pyramid was laid down, once for all, by the architect, according to the instructions which 
he had received, and the resources placed at his disposal. He then followed it out to the end of the work, without increasing or reducing the scale (Note I 7).

The pyramids were required to have their four faces to the four cardinal points, like the mastabas; but, either from bad management or neglect, the greater part are not oriented exactly, and many vary distinctly from the true north (Note I8). Without speaking of the ruins of Aboo Roash or Zowyet-el-Aryan, which have not been studied closely enough, they naturally form six groups, distributed from north to south on the border of the Libyan plateau, from Gizeh to the Fayoom, by Abooseer, Sakkarah, Dashoor, and Lisht. The Gizeh group contains nine, including those of Khoofoo, Khafra, and Menkara, which were anciently reckoned among the wonders of the world. The ground on which the pyramid of Khoofoo stands was very irregular at the time of construction. A small rocky height which rose above the surface was roughly cut (fig. 29A) and enclosed in the masonry, the rest being smoothed and covered with large slabs, some of which still remain (Note I9). The pyramid itself was 48I feet high and 755 feet wide, which the injuries of time have reduced to 454 feet and 750 feet respectively. It preserved until the Arab conquest a casing of stones of different colours (Note 20), so skilfully joined that they appeared like one block from the base to the top. The casing work was begun from the top, and the cap placed on first, the steps being covered one after the other, until they reached the bottom (Note 2I). In the inside all was arranged so as to hide the exact place of the sarcophagus, and to baffle any spoilers 
whom chance or perseverance had led aright. The first point was to discover the entrance under the casing, which masked it. It was nearly in the middle of the north face (fig. I32, B); but at the level of the eighteenth course, at about forty-five feet from the ground. When the block which closed it was displaced, one entered on an inclined passage, $4 \mathrm{I}^{\cdot} 2$ inches wide and 47.6 inches high, the lower part of which was cut in the rock. It descended for 3I 7 feet, passed through an unfinished chamber (c), and ended sixty feet further

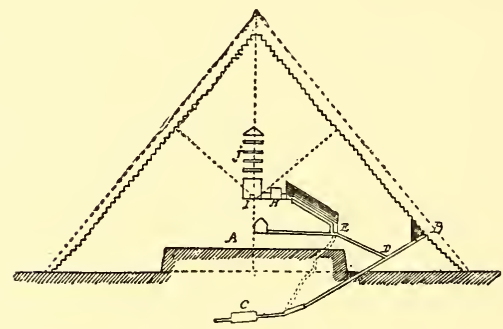

Fig. 132.- Section of the Great Pyramid. in a blind passage. This would be a first disappointment to the spoilers. If, however, they were not discouraged, but examined the passage with care, they would find in the roof, sixty-two feet

distant from the door, a block of granite (Note 22) among the surrounding limestone (D). It was so hard that the seekers, after having vainly tried to break or remove it, took the course of forcing a way through the softer stones around (Note 23). This obstacle past, they came into an ascending passage which joins the first at an angle of $120^{\circ}$ (Note 24), and is divided into two branches (E). One branch runs horizontally into the centre of the pyramid, and ends in a limestone chamber with pointed roof, which is called, without any good reason. "The Queen's Chamber" (F). The other, continuing upward, changes its form and appearance. It 
becomes a gallery 148 feet long and 28 feet high, built of fine Mokattam stone, so polished and finely wrought that it is difficult to put a "needle or even a hair" into the joints (Note 25). The lower courses are vertical over each other, the seven others corbel forwards, until at the roof they are only twenty-one inches apart. A fresh obstacle arose at the end (G). The passage which led to the chamber of the sarcophagus was closed by a slab of granite (Note 26); further on was a small vestibule $(\mathrm{H})$ divided in equal spaces by four portcullises of granite (Note 27), which needed to be broken. The royal sepulchre (I) is a granite chamber with a flat roof, nineteen feet high, thirty-four feet long, and seventeen feet wide. One sees there neither figure nor inscription; nothing but a granite sarcophagus, lidless and mutilated. Such were the precautions taken against invaders; and the result showed that they were effectual, for the pyramid guarded its deposit during more than four thousand years (Note 28). But the very weight of the materials was a more serious danger. To prevent the sepulchral chamber from being crushed by the three hundred feet of stone which stood over it, they left above it five low hollow spaces, one over the other $(\mathrm{J})$. The last is sheltered by a pointed roof, formed of two enormous slabs (Note 29) leaning one against the other. Thanks to this device, the central pressure was thrown almost entirely on the side faces, and the chamber was preserved. None of the stones which cover it have been crushed; none have yielded a fraction since the day when the workmen cemented them into their places (Note 30). 
The pyramids of Khafra and Menkara were built on a different plan inside to that of Khoofoo. Khafra's had two entrances, both to the north, one from the platform before the pyramid, the other fifty feet above the ground. Menkara's still preserves the remains of its casing of red granite (Note 3I). The entrance passage descends at an angle of twenty-six degrees, and soon runs into the rock. The front chamber is decorated with panels sculptured in the stone, and was closed at

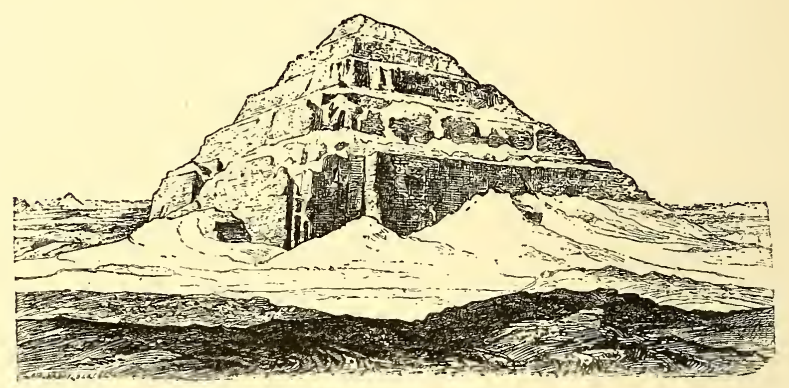

Fig. 133--The Step Pyramid of Sakkarah.

the further end by three portcullises of granite. The second chamber appears to be unfinished, but this was a trap to deceive the spoilers. A passage cut in the floor, and carefully hidden, gave access to a lower chamber. There lay the mummy in a sarcophagus of sculptured basalt. The sarcophagus was still perfect at the beginning of this century. Removed thence by Colonel Howard Vyse, it foundered on the Spanish coast with the ship which was bearing it to England.

The same variety of arrangement prevails in the groups of Abooseer, and in one part of the Sakkarah 
group. The great pyramid of Sakkarah is not oriented with exactness. The north face is turned $4^{\circ} 2 \mathrm{I}^{\prime}$ from the true north. It is not a perfect square, but is elongated from east to west, the sides being 395 and 35 I feet. It is 196 feet high, and is formed of six great steps with inclined faces, each retreating about seven feet; the step nearest the ground is thirty-seven and a half feet high, and the top one is twenty-nine feet high (fig. I33). It is built entirely with limestone, quarried from the neighbouring hills. The blocks are small and badly cut, and the courses are concave, according to a plan applied both

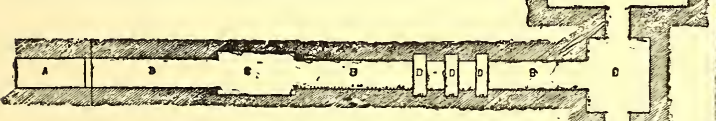

Fig. 134.- Plan of the Pyramid of Unas.

to quays and to fortresses. On examining the breaches in the masonry, it is seen that the

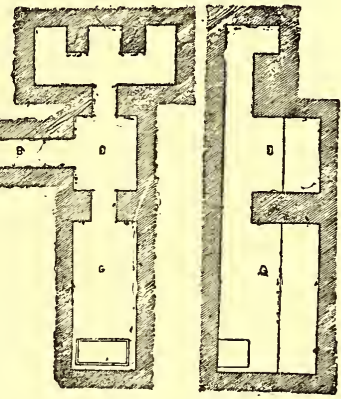
outer face of each step is coated with two layers, each of which has its regular casing (Note 32). The mass is solid, the chambers being cut in the rock below the pyramid. It has four entrances, the main one being in the north; and the passages form a perfect labyrinth, which it is perilous to enter. Porticoes with columns, galleries, and chambers, all end in a kind of pit, in the bottom of which a hiding place was contrived, doubtless intended to contain the most precious objects of the funereal furniture. The pyramids which surround this extraordinary monument 
have been nearly all built on one plan, and only differ in their proportions. The door (fig. I34, A) opens close below the first course, about the middle of the north face, and the passage (B) descends by a gentle slope between two walls of limestone. It is plugged up all along by large blocks (Note 33) which needed to be broken up before reaching the first chamber (c). On leaving this chamber, it was carried for some way through the limestone rock; then it passes between four walls of polished sye-

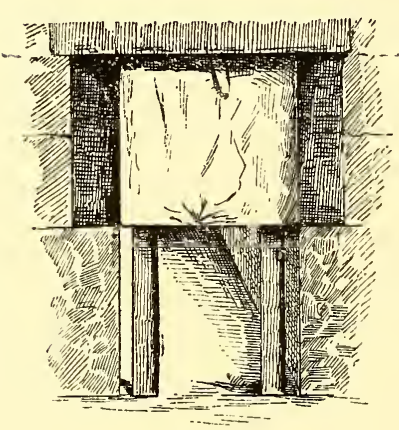

Fig. I35. nite ; after which the limestone re-appears, and the passage opens into the vestibule (E). The part built of granite is interrupted thrice, at intervals of two to two and a half feet, by three enormous portcullises of granite (D). Above each of these a hollow is left, in which the portcullis stone was held up by props, which left a free passage (fig. I35). The mummy once placed inside, the workmen, as they left, removed the supports, and the portcullises fell into place, cutting off all communication with the outside. The vestibule was flanked on the east by a flat-roofed serdab divided into three niches, and encumbered with chips of stone swept hastily in by the slaves at the last moment when they cleared the chambers to receive the mummy. The pyramid of Unas has all three niches preserved; but in that of Teti and 
of Merenra, the separating walls (F) have been very neatly cut away in ancient times, without leaving any trace but a line of attachment, and a whiter colour in the stone where it had been originally covered. The sarcophagus chamber (G) extends west of the vestibule ; the sarcophagus was placed there along the west wall, feet to the south, head to the north $(\mathrm{H})$. The roof over the two main chambers was pointed. It was formed of large beams of limestone, joined at the upper ends, and supported below upon a low bench (I) which surrounded the chamber outside (Note 34). The first

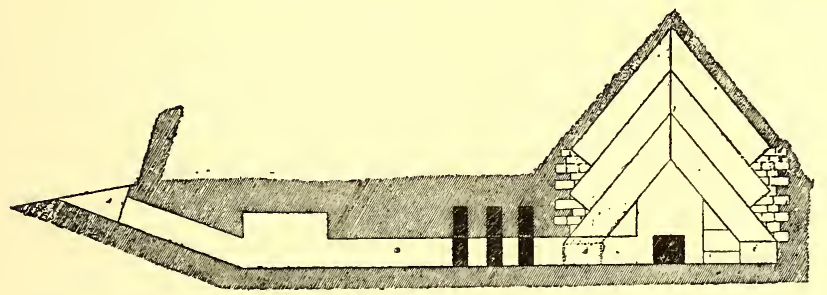

Fig. 136.-Section of the Pyramid of Unas.

beam was covered by a second, and this by a third; and the three together (I) thoroughly protected the vestibule of the vault (fig. 136).

The pyramids of Gizeh belonged to the Pharaohs of the Fourth Dynasty, and those of Abooseer to the Pharaohs of the Fifth. The five pyramids of Sakkarah, of which the plan is uniform, belonged to Unas and to the first four kings of the Sixth Dynasty, Teti, Pepi I., Merenra, and Pepi II., and are contemporary with the mastabas with painted vaults which I have mentioned above. One is not astonished, therefore, to find them inscribed and decorated. The ceilings are 
covered with stars, to represent the sky and the night. The rest of the decoration is very simple. In the pyramid of Unas, which is the most ornamented, the decoration occupies only the end wall of the funereal chamber; the part against the sarcophagus was lined with alabaster, and engraved to represent great monumental doors, through which the deceased was supposed to enter his storerooms of provisions. The figures of men and of animals, the scenes of daily life, the details of the sacrifice, are not here represented, and, moreover, would not be in keeping; they belong to those places where the Double lived his public life, and where visitors actually performed the rites of offering; the passages and the vault in which the soul alone was free to wander could receive no ornamentation, except that which related to the life of the soul. The texts are of two kinds. One kind-and these are the fewest-refer to the nourishment of the Double, and are literal transcriptions of the formulas by which the priests ensured the transmission of each object from hence to the other world; this was a last resource for him, in case the real sacrifices should be discontinued, or the magic scenes upon the chapel walls be destroyed. The greater part of the inscriptions were of a different kind. They referred to the soul, and were intended to preserve it from the dangers which awaited it, in heaven and on earth. They revealed to it the sovereign incantations which protected it against the bites of serpents and venomous animals, the passwords which enabled it to enter into the company of the good gods, and the exorcisms which counteracted the influence of the evil gods. Just as the destiny of the Double was 
to continue to lead the shadow of its terrestrial life, and fulfil it in the chapel, so it was the destiny of the Soul to follow the sun across the sky, and it, therefore, needed the instructions which it read on the walls of the vault. It was by their virtue that the absorption of the dead into Osiris became complete, and that he enjoyed hereafter all the immunity of the divine state. Above, in the chapel, it was a man and it acted as a man; here it was a god, and it acted as a god.

The enormous rectangular mass which the Arabs call Mastabat el Faraoon, "the seat of Pharaoh"

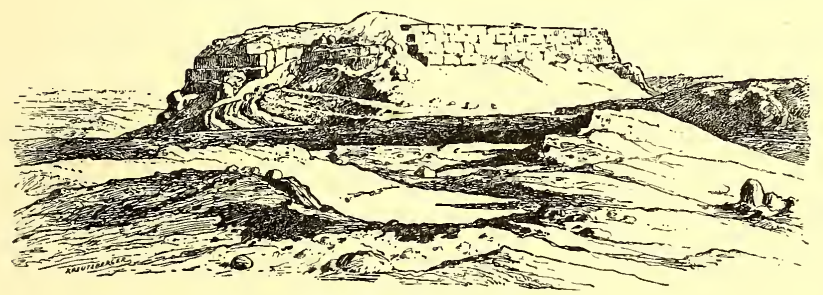

Fig. 137.--Mastabat el Faraoon.

(fig. I37), stands beside the pyramid of Pepi II. Some have thought it to be an unfinished pyramid, some a tomb surmounted by an obelisk ; in reality it is a royal mastaba, the inside of which is arranged on the plan of a pyramid. Mariette thought that Unas was buried there; but recent excavations have shown this to be impossible. They have, on the other hand, apparently shown that the southern brick pyramid of Dashoor belonged to Seneferu. If this fact should be confirmed by future researches, there is some chance that this whole group is the oldest of all, and that it goes back to the Third Dynasty. The Dashoor group 
furnishes a curious variation from the usual type. One of the stone pyramids has the lower half inclined at $54^{\circ} 4 \mathrm{I}^{\prime}$, while the upper part changes sharply to $42^{\circ} 59^{\prime}$; it might be called a mastaba (Note 35) crowned by a gigantic attic. At Lisht, one leaves the Old Kingdom for the Theban Dynasties, and the structure is again changed. The sloping passage ends in a vertical shaft, at the bottom of which open chambers now filled by the infiltration of the Nile.

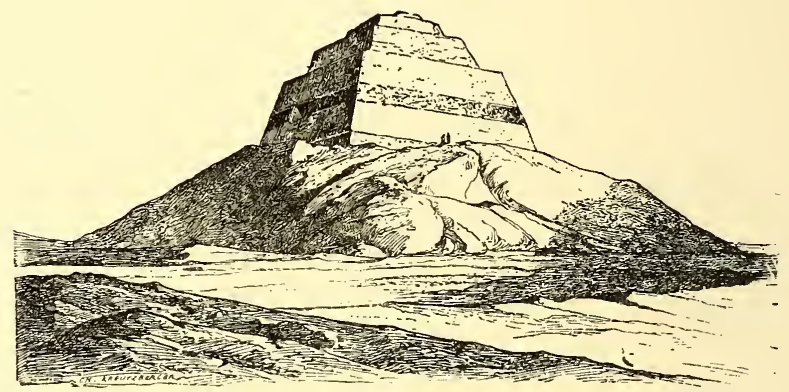

Fig. I38.-Pyramid of Meydoom.

The Fayoom group belongs entirely to the Twelfth Dynasty; but the pyramids of Biahmoo are almost entirely destroyed. The pyramid of Illahoon has never been explored, and that of Meydoom, violated before the Ramesside age, is empty. It consists of three square towers (Note 39) with sides slightly sloping, placed in retreating stages one over the other (fig. I38). The entrance is on the north, at about 53 feet above the sand. After 60 feet, the passage goes into the rock; at 174 feet it turns level; at forty feet further it stops, and turns perpendicularly 
up to the surface, opening in the floor of a vault twenty-one feet higher (fig. I 39). A set of beams and ropes still in place above the opening show that the spoilers drew the sarcophagus out of the chamber in ancient times. The custom of building pyramids did not end with the Twelfth Dynasty; we know of some at Manfaloot, at Hekalli to the south of Abydos, and at Mohammerieh to the south of Esneh. Until the Roman period, the semi-barbarous sovereigns of Ethiopia held it as a point of honour to give the pyramidal form to their tomb. The oldest, those of

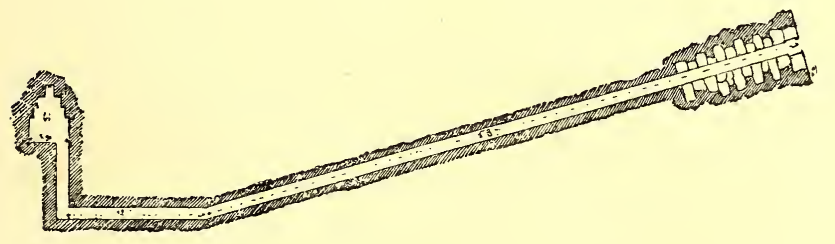

Fig. 139.

Nourri, where the Pharaohs of Napata sleep, recall by their style the pyramids of Sakkarah ; the latest, those of Meroë, present fresh characteristics. They are higher than they are wide, are built of small blocks, and are sometimes decorated at the angles with rounded borderings. The east face has a false window, surmounted by a cornice, and is flanked by a chapel, which is preceded by a pylon. These pyramids are not all dumb. As in ordinary tombs, the walls contain scenes borrowed from the "Ritual of Burial," or showing the vicissitudes of the life beyond the grave. 


\section{3.-The Tombs of the Theban Empire.}

\section{Excavated Tombs.}

The latest known mastabas belong to the Twelfth Dynasty. They are grouped together in the sandy plain of Meydoom, and have never been finished. Two subsequent systems replaced the mastaba throughout Egypt. The first pre-

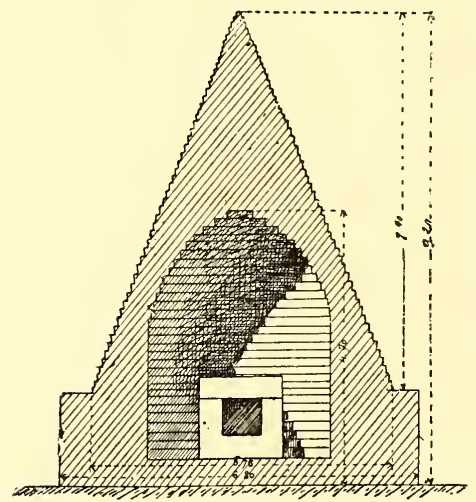

Fig. I40. serves the chapel constructed above ground, and combines the pyramid with the mastaba; the second excavates the whole tomb in the rock including the chapel.

The necropolis quarter of Abydos, in which were interred the earlier generations of the Theban Empire, furnish the most ancient examples of the first system. The tombs are built of large, black, unbaked bricks, made without any mixture of straw or grit. The lower part is a mastaba with a square or oblong rectangular base, the longest side of the latter being sometimes as much as forty or fifty feet. The walls are perpendicular, and are seldom high enough for a man to stand upright inside the tomb. On this kind of pedestal was erected a pointed pyramid of from 12 to 30 feet in height, covered externally with a smooth coat of clay 
painted white. The defective nature of the rock below forbade the excavation of the funereal chamber; there was no resource, therefore, except to hide it in the brickwork. An oven-shaped chamber with corbel vault was constructed in the centre (fig. I40); but more frequently the sepulchral chamber is found to be half above ground in the mastaba and half sunk in the

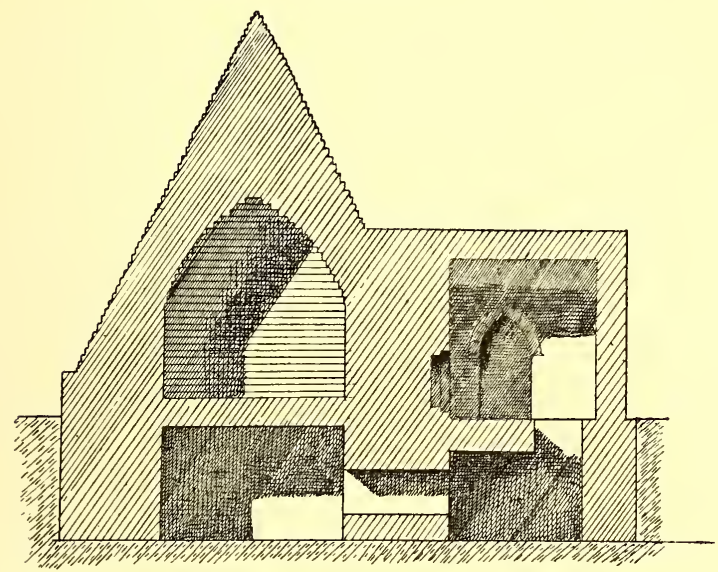

Fig. I4I.

foundations, the vaulted space above being left only to relieve the weight (fig. I4I). In many cases there was no external chapel, the stela, placed in the basement, or set in the outer face, alone marking the place of offering. In other instances a square vestibule was constructed in front of the tomb where the relations assembled (fig. I42). Occasionally a breast-high enclosure wall surrounded the monument, and defined the boundaries of the ground belonging to the tomb. This mixed form was 
much employed in Theban cemeteries from the beginning of the Middle Empire. Many kings and nobles of the Eleventh Dynasty were buried at

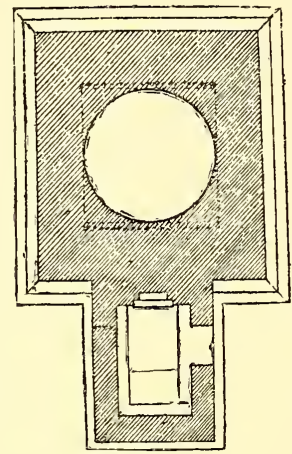

Fig. I 42 . Drah-Aboo'l Neggah, in tombs like those of Abydos (fig. I43). The relative proportion of mastaba and pyramid became modified during the succeeding centuries. The mastaba-often a mere insignificant substructure — gradually returned to its original $\mathrm{h}$ e i g h t, while the pyramid as gradually decreased, and ended by being only an unimportant pyra-

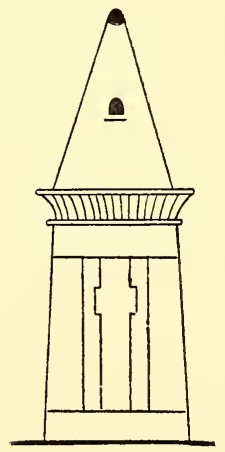

Fig. I44. midion (fig. I44).

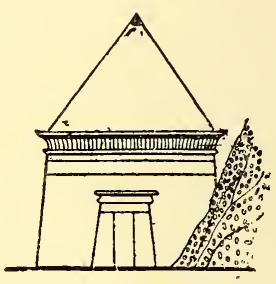

Fig. I43. All the monuments of this type which ornamented the Theban necropolis during the Ramesside period have perished, but contemporary tomb-paintings show many varieties, and the chapel of an Apis which died during the reign of Amenhotep III. still remains to show that this fashion extended as far as Memphis. Of the pyramidion, scarcely any traces remain; but the mastaba is intact. It is a square mass of limestone, raised on a base, supported by four columns at the corners, and sur- 
mounted by an overhanging cornice; a flight of five steps leads up to the inner chamber (fig. I45).

The earliest examples of the second kind, namely, those found at Gizeh among the mastabas of the Fourth Dynasty, are neither large nor much ornamented. They begin to be carefully wrought about the time of the Sixth Dynasty, and in certain distant places, as Bersheh, Sheykh-Said, Kasr-es-Sayad, Assouan, and Negadeh. The rock-cut tomb did not, however, attain its full development until a somewhat later period, i.e., during the centuries which intervened between the last Memphite kings and the first kings of the Theban line.

In these rock-cut tombs we find all the various parts of the mastaba. The designer selected a prominent vein of limestone,

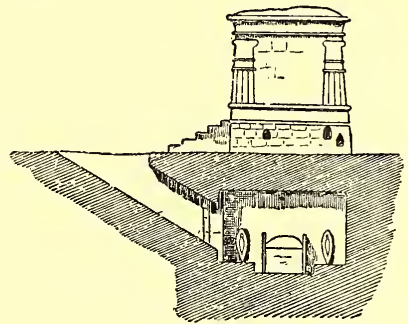

Fig. 145 . high enough in the cliff side to risk nothing from the gradual rising of the soil, and yet low enough for the funeral procession to reach it without difficulty. The finest tombs belong to the great feudal families of this period. The lords of Minieh slept at Beni Hassan; those of Khmounou at Bersheh; those of Siout and Elephantine at Siout and in the cliff opposite Assouan (fig. I46). Sometimes, as at Siout, Bersheh, and Thebes, the tombs are dispersed at various levels; sometimes, as at Beni Hassan, they follow the line of the stratum, and are ranged in nearly horizontal terraces. A flight of steps, rudely con- 
structed in rough-hewn stones, leads up from the plain to the entrance of the tomb. At Beni Hassan and Thebes, these steps are either destroyed or buried in sand; but recent excavations have brought to light a well-preserved example leading up to a tomb at Assouan.*

The funeral procession, having slowly scaled the cliffside, halted for a moment at the entrance to the chapel. The plan was not necessarily uniform throughout any one group of tombs. Several of the Beni Hassan tombs

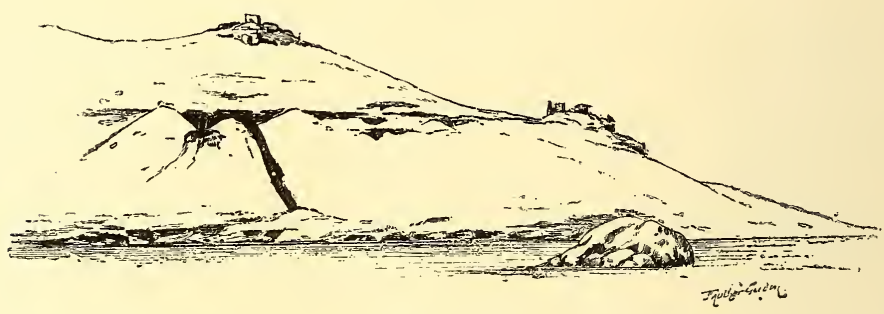

Fig. I46.

have porticoes, the pillars, bases, and entablatures, being all cut in the rock; those of Amoni and Khnumhotep have porticoes supported on two polygonal columns (fig.

* The steps are shown in fig. 146. They were discovered by General Sir F. Grenfell in 1885. Noting the remains of two parallel walls running up from the water's edge to a part of the cliff which had evidently been escarped and presented a vertical face, General Grenfell caused the sand to be cleared, thus disclosing the entrances to several rock-cut tombs dating from the Sixth and Twelfth Dynasties, as well as two flights of steps on either side of an inclined plane leading from the Nile bank to the door of one of the tombs. The distance between the two walls is ten feet. The steps are eighteen inches deep, and 250 in number. The steps were for the haulers, the mummies and sarcophagi being dragged up the inclined plane. 
I47). At Assouan (fig. 148), the doorway forms a high and narrow recess cut in the rock wall, but is divided, at about one-third of its height, by a rectangular lintel, thus making a smaller doorway in the doorway itself. At Siout, the tomb of Hapizefa was entered by a true porch about twenty-four feet in height, with a vaulted roof elegantly sculptured and painted. More frequently

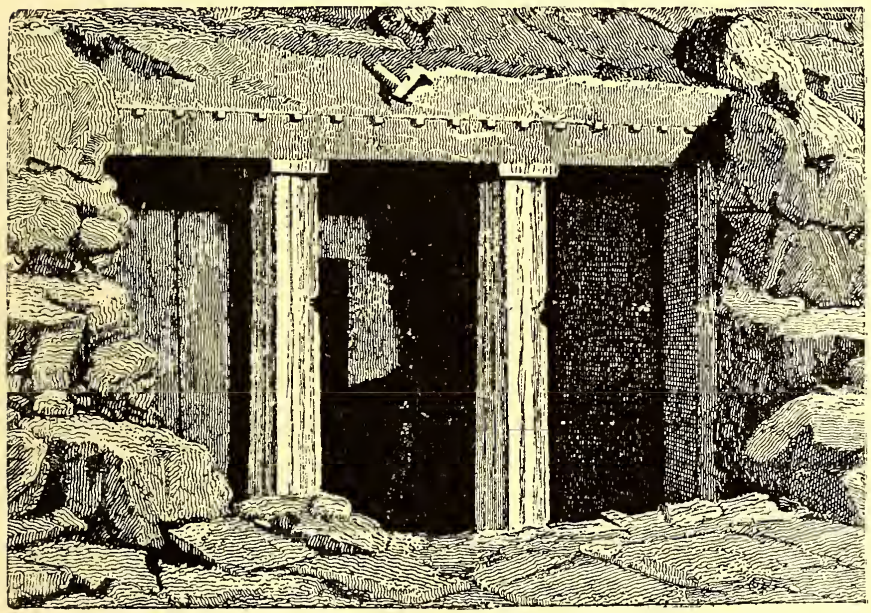

Fig. I47.

the side of the mountain was merely cut away, and the stone dressed over a more or less extent of surface, according to the intended dimensions of the tomb. This method ensured the twofold advantage of clearing a little platform closed in on three sides in front of the tomb, and also of forming an upright façade which could be decorated or left plain, according to the taste of the proprietor. The door, sunk in the middle of this 
façade, has sometimes no framework; sometimes, however, it has two jambs and a lintel, all slightly projecting. The inscriptions, when any occur, are very simple, consisting of one or two horizontal lines above, and one or two vertical lines down each side, with the addition

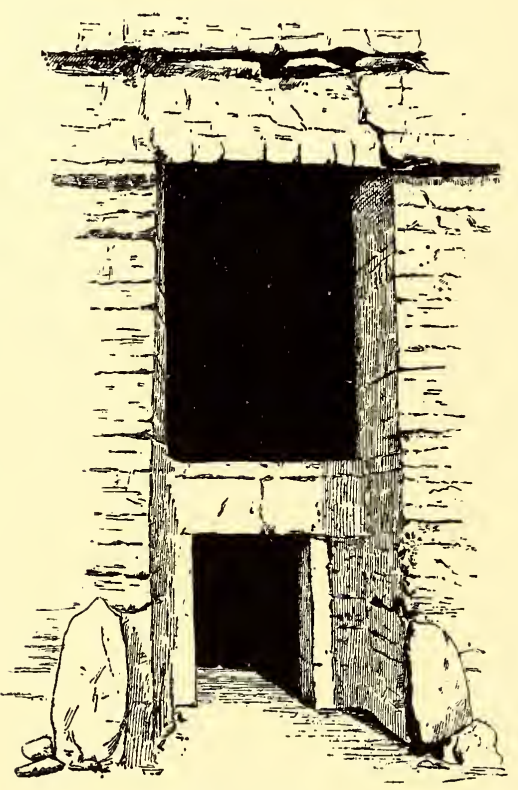

Fig. 148 . perhaps of a sitting or standing figure. These inscriptions contain a prayer, as well as the name, titles, and parentage of the deceased. The chapel generally consists of a single chamber, either square or oblong, with a flat or a slightly vaulted ceiling. Light is admitted only through the doorway. Sometimes a few pillars, left standing in the rock at the time of excavation, give this chamber the aspect of a little hypostyle hall. Four such pillars decorate the chapels of Amoni and Khnumhotep at Beni Hassan. Other chapels contain six or eight, and are very irregular in plan. Tomb No. 7 was in the first instance a simple oblong hall, with a barrel roof and six columns. Later 
on, it was enlarged on the right side, the new part forming a kind of flat-roofed portico supported on four columns (fig. I 50).

To form a serdab in the solid rock was almost impossible; while on the other hand, movable statues, if left in a room accessible to all comers, would be exposed to theft or mutilation. The serdab, therefore, was transformed, and combined with the stela of the ancient mastabas. The false door of the olden time became a niche cut in the end wall, almost always facing the entrance. Statues of the deceased and his wife, carved in the solid rock, were there enthroned

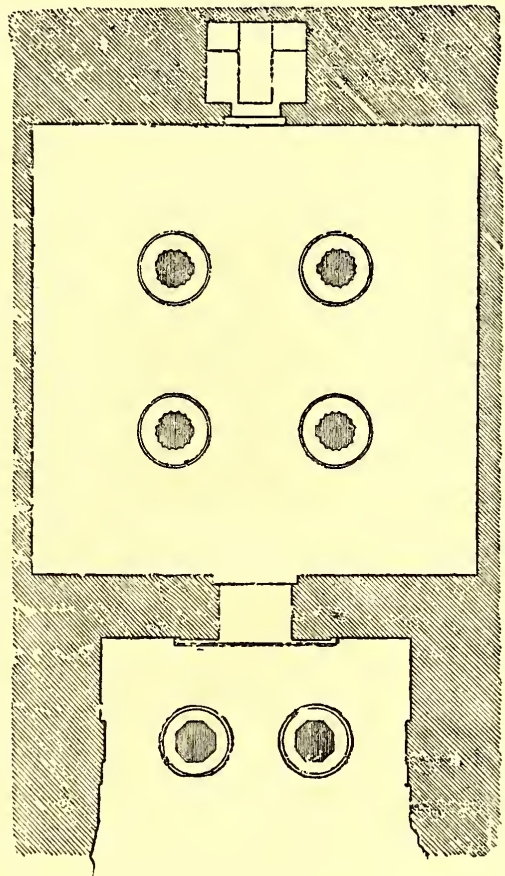

Fig. I49. (Note 45). The walls were decorated with scenes of offerings, and the entire decoration of the tomb converged towards the niche, as that of the mastaba converged towards the stela. The series of tableaux is, on the whole, much the same as of old, though with certain noteworthy additions. The funeral pro- 
cession, and the scene where the deceased enters into possession of his tomb, both merely indicated in the mastaba, are displayed in full upon the walls of the Theban sepulchre. The mournful cortège is there, with the hired mourners, the troops of friends, the bearers of offerings, the boats for crossing the river, and the catafalque drawn by oxen. It arrives at the door of the tomb. The mummy, placed upright upon his

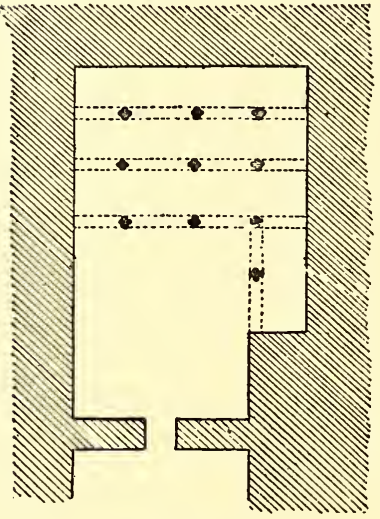

Fig. 150. feet, receives the farewell of his family; and the last ceremonies, which are to initiate him into the life beyond the grave, are duly performed (fig. I 5I). The sacrifices, with all the preliminary processes, as tillage, seed - growing, harvesting, stock - breeding, and the practice of various kinds of handicraft, are either sculptured or painted, as before. Many details, however, which are absent from tombs of the earlier dynasties are here represented, while others which are invariably met with in the neighbourhood of the pyramids are lacking. Twenty centuries work many changes in the usages of daily life, even in conservative Egypt. We look almost in vain for herds of gazelles upon the walls of the Theban tombs, for the reason that these animals, in Ramesside times, had ceased to be bred in a state of domestication. The horse, on the other hand, had been imported into the valley of the Nile, 
and is depicted pawing the ground where formerly the gazelle was seen cropping the pasturage. The trades are also more numerous and complicated; the workmen's tools are more elaborate; the actions of the deceased are more varied and personal. In former times, when first the rules of tomb decoration were

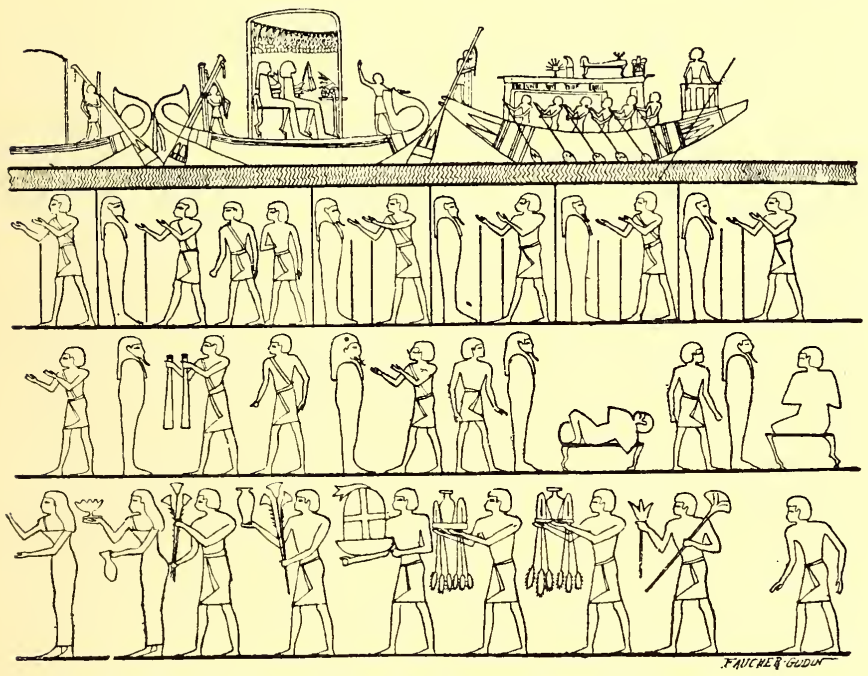

Fig. 151 .

formulated, the notion of future retribution either did not exist, or was but dimly conceived. The deeds which he had done here on earth in no wise influenced the fate which awaited the man after death. Whether good or bad, from the moment when the funeral rites were performed and the necessary prayers recited, he was rich and happy. In order to establish his identity, it was enough to record his name, 
his title, and his parentage; his past was taken for granted. But when once a belief in rewards and punishments to come had taken possession of men's minds, they bethought them of the advisability of giving to each deceased the benefit of his individual merits. To the official register of his social status, they now therefore added a brief biographical notice. At first, this consisted of only a few words ; but towards the time of the Sixth Dynasty (as where Una recounts his public services under four kings), these few words developed into pages of contemporary history. With the beginning of the New Empire, tableaux and inscriptions combine to immortalise the deeds of the owner of the tomb. Khnumhotep of Beni-Hassan records in full the origin and greatness of his ancestors. Khiti displays upon his walls all the incidents of a military life-parades, war-dances, sieges, and sanguinary battle scenes. In this respect, as in all others, the Eighteenth Dynasty perpetuates the tradition of preceding ages. Aï, in his fine tomb at Tell-elAmarna, recounts the episode of his marriage with the daughter of Khoo-en-Aten. Neferhotep of Thebes, having received from Horemheb the decoration of the Golden Collar, complacently reproduces every little incident of his investiture, the words spoken by the king, as also the year and the day when this crowning reward was conferred upon him. Another, having conducted a survey, is seen attended by his subordinates with their measuring chains; elsewhere he superintends a census of the population, just as $\mathrm{Ti}$ formerly superintended the numbering of his cattle. The stela partakes of these new characteristics in wall- 
decoration. In addition to the usual prayers, it now proclaims the praises of the deceased, and gives a summary of his life. This is too seldom followed by a list of his honours with their dates.

When space permitted, the vault was excavated immediately below the chapel. The shaft was sometimes sunk in a corner of one of the chambers, and sometimes outside, in front of the door of the tomb. In the great cemeteries, as for instance at Thebes and Memphis, the superposition of these three partsthe chapel, the shaft, and the vault-was not always possible. If the shaft were carried to its accustomed depth, there was sometimes the risk of breaking into tombs excavated at a lower level. This danger was met either by driving a long passage into the rock, and then sinking the shaft at the farther end, or by substituting a slightly sloping or horizontal disposition of the parts for the old vertical arrangement of the mastaba model. The passage in this case opens from the centre of the end wall, its average length being from 20 to $\mathrm{I} 30$ feet. The sepulchral vault is always small and plain, as well as the passage. Under the Theban dynasties, as under the Memphite kings, the Soul dispensed with decorations; but when once it was decided to decorate the walls, the figures and inscriptions are found to relate chiefly to the life of the Soul, and very slightly to the life of the Double. In the tomb of Horhotep, which is of the time of the Usertesens, and in similar rock-cut sepulchres, the walls (except on the side of the door) are divided into two registers. The upper row belongs to the Double, and contains, besides the table. 
of offerings, pictured representations of the same objects which are seen in certain mastabas of the Sixth Dynasty; namely, stuffs, jewels, arms, and perfumes, all needful to Horhotep for the purpose of imparting eternal youth to his limbs. The lower register belonged to both the Soul and the Double, and is inscribed with extracts from a variety of liturgical writings, such as The Book of the Dead, the Ritual of Embalmment, and the Funeral Ritual, all of which were possessed of magic properties which protected the Soul and supported the Double. The stone sarcophagus, and even the coffin, are also covered with closely-written inscriptions. Precisely as the stela epitomised the whole chapel, so did the sarcophagus and coffin epitomise the sepulchral chamber, thus forming, as it were, a vault within a vault. Texts, tableaux, all thereon depicted, treat of the life of the Soul, and of its salvation in the world to come.

At Thebes, as at Memphis, the royal tombs are those which it is most necessary to study, in order to estimate the high degree of perfection to which the decoration of passages and sepulchral chambers was now carried. The most ancient were situate either in the plain or on the southern slopes of the western mountain; and of these, no remains are extant. The mummies of Amenhotep I., of Thothmes III., of Sekenen-Ra, and Aahhotep have survived the dwellings of solid stone designed for their protection. Towards the middle of the Eighteenth Dynasty, however, all the best places were taken up, and some unoccupied site in which to establish a new royal cemetery had to be sought. At first they went to a considerable distance; namely, to the end 
of the valley (known as the Western Valley), which opens from near Drah-Aboo-l-Neggah. Amenhotep III., Aï, and perhaps others, were there buried. Somewhat later, they preferred to draw nearer to the city of the living. Behind the cliff which forms the northern boundary of the plain of Thebes, there lay a kind of rocky basin closed in on every side, and accessible from the outer world by only a few perilous paths. It divides into two branches, which cross almost at right angles. One branch turns to the south-east, while the other, which again divides into secondary branches, turns to the south-west. Westward rises a mountain which recalls upon a gigantic scale the outline of the great steppyramid of Sakkarah.* The Egyptian engineers of the time observed that this basin was separated from the ravine of Amenhotep III. by a mere barrier some 500 cubits in thickness. In this there was nothing to dismay such practised miners. They therefore cut a trench some fifty or sixty cubits deep through the solid rock, at the end of which a narrow passage opens like a gateway into the hidden valley beyond. Was it in the time of Horemheb, or during the reign of Rameses I., that this gigantic work was accomplished? Rameses I. is, at all events, the earliest king whose tomb has as yet been found in this spot. His son, Seti I., then his grandson, Rameses II., came hither to rest beside him. The Ramesside Pharaohs followed one after the other. Her-Hor may perhaps have been the last of the series. These crowded catacombs caused the place to be called "The Valley of the Tombs of the Kings,"-a name which it retains to this day.

* See fig. I33. 
These tombs are not complete. Each had its chapel ; but those chapels stood far away in the plain, at Goornah, at the Ramesseum, at Medinet-Haboo ; and they have already been described. The Theban rock, like the Memphite pyramid, contained only the passages and the sepulchral chamber. During the daytime, the pure Soul was in no serious danger; but in the evening, when the eternal waters which flow along the vaulted heavens fall in vast cascades adown the west and are engulfed in the bowels of the earth, the Soul follows the bark of the Sun and its escort of luminary gods into a lower world bristling with ambuscades and perils. For twelve hours, the divine squadron defiles through long and gloomy corridors, where numerous genii, some hostile, some friendly, now struggle to bar the way, and now aid it in surmounting the difficulties of the journey. Great doors, each guarded by a gigantic serpent, were stationed at intervals, and led to an immense hall full of flame and fire, peopled by hideous monsters and executioners whose office it was to torture the damned. Then came more dark and narrow passages, more blind gropings in the gloom, more strife with malevolent genii, and again the joyful welcoming of the propitious gods. At midnight began the upward journey towards the eastern regions of the world ; and in the morning, having reached the confines of the Land of Darkness, the sun emerged from the east to light another day. The tombs of the kings were constructed upon the model of the world of night. They had their passages, their doors, their vaulted halls, which plunged down into the depths of the mountain. Their position in the valley was determined by no consideration of dynasty or succession. 
Each king attacked the rock at any point where he might hope to find a suitable bed of stone; and this was done with so little regard for his predecessors, that the workmen were sometimes obliged to change the direction of the excavation in order not to invade a neighbouring catacomb. The designer's plan was a

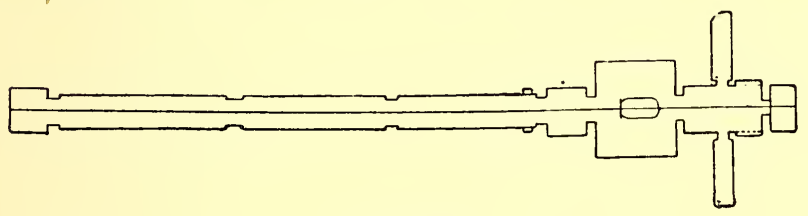

Fig. 152.

mere sketch, to be modified when necessary, and which was by no means intended to be strictly carried out. Hence the plan and measurement of the actual tomb of Rameses IV. (fig. I 52) differ in the outline of the sides and in the general arrangement from the plan of that same tomb which is preserved on a papyrus in the Turin

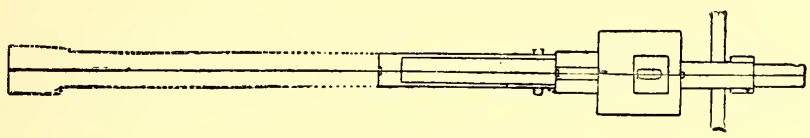

Fig. 153.

Museum (fig. I 53). Nothing, however, could be more simple than the ordinary distribution of the parts. A square door, very sparingly ornamented, opened upon a passage leading to a chamber of more or less extent. From the further end of this chamber opened a second passage leading to a second chamber, and thence sometimes to more chambers, the last of which contained the sarcophagus. In some tombs, the whole excavation is 
carried down a gently inclined plane, broken perhaps by only one or two low steps between the entrance and the end. In others, the various parts follow each other at lower and lower levels. In the catacomb of Seti I., (fig. I 54) a long and narrow flight of stairs and a sloping corridor (A) lead to a little antechamber and two halls (B) supported on pillars. A second staircase (C) leads through a second antechamber to another pillared hall (D), which was the hiding-place of the sarcophagus. The tomb did not end here. A third staircase (E) opening from the end of the principal hall

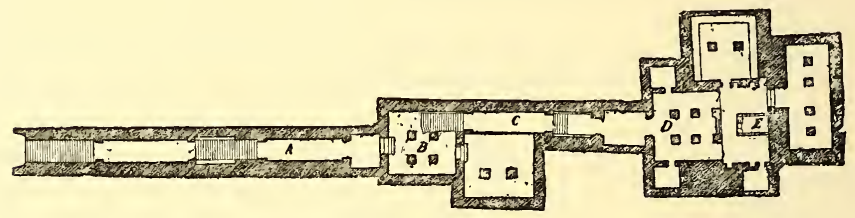

Fig. 154 .

was in progress, and would no doubt have led to more halls and chambers, had not the work been stopped by the death of the king. ${ }^{*}$ If we go from catacomb to catacomb, we do not find many variations upon this plan. The entrance passage in the tomb of Rameses III. is flanked by eight small lateral chambers. In almost every other instance, the lesser or greater length of the passages, and the degree of finish given to the wall paintings, constitute the only differences between one tomb and another. The smallest of these catacombs

* M. Léfébure has lately produced a superb and elaborate volume on this tomb, with the whole of the texts and the wall decorations, faithfully reproduced : Annales du Musée Guimet, Tome ix. [Translator's note.] 
comes to an end at fifty-three feet from the entrance; that of Seti I., which is the longest, descends to a distance of 470 feet, and there remains unfinished. The same devices to which the pyramid builders had recourse, in order to mislead the spoiler, were adopted by the engineers of the Theban catacombs. False shafts were sunk which led to nothing, and walls sculptured and painted were built across the passages. When the burial was over, the entrance was filled up with blocks of rock, and the natural slope of the mountain side was restored as skilfully as might be.

The most complete type of this class of catacomb is that left to us by Seti I. ; figures and hieroglyphs alike are models of pure design and elegant execution. The tomb of Rameses III. already points to decadence. It is for the most part roughly painted. Yellow is freely laid on, and the raw tones of the reds and blues are suggestive of the early daubs of our childhood. Mediocrity ere long reigned supreme, the outlines becoming more feeble, the colour more and more glaring, till the latest tombs are but caricatures of those of Seti I. and Rameses III. The decoration is always the same, and is based on the same principles as the decoration of the pyramids. At Thebes as at Memphis, the intention was to secure to the Double the free enjoyment of his new abode, and to usher the Soul into the company of the gods of the solar cycle and the Osirian cycle, as well as to guide it through the labyrinth of the infernal regions. But the Theban priests exercised their ingenuity to bring before the eyes of the deceased all that which the Memphites consigned to his memory by means of writing, thus 
enabling him to see what he had formerly been obliged to read upon the walls of his tomb. Where the texts of the pyramid of Unas relate how Unas, being identified with the sun, navigates the celestial waters or enters the Elysian Fields, the pictured walls of the tomb of Seti I. show Seti sailing in the solar bark, while a side chamber in the tomb of Rameses III. shows Rameses III. in the Elysian Fields (fig. I 55). Where the walls of the pyramid of Unas give the prayers recited over the mummy to open his mouth,

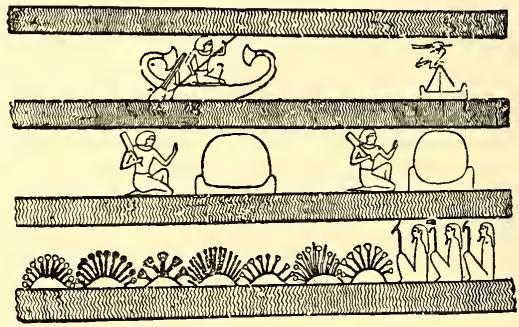

Fig. 155 .

to restore the use of his limbs, to clothe, to perfume, to feed him, the walls of Seti's catacomb contain representations of the actual mummy, of the $\mathrm{Ka}$ statues which are the supports of his Double, and of the priests who open their mouths, who clothe them, perfume them, and offer them the various meats and drinks of the funeral feast. The ceilings of the pyramid chambers were sprinkled over with stars to resemble the face of the heavens; but there was nothing to instruct the Soul as to the names of those heavenly bodies. On the ceilings of some of the Theban catacombs, we not only find the constellations 
depicted, each with its personified image, but astronomical tables giving the aspect of the heavens fortnight by fortnight throughout the months of the Egyptian year, so that the Soul had but to lift its eyes and see in what part of the firmament its course lay night after night. Taken as a series, these tableaux form an illustrated narrative of the travels of the sun and the Soul throughout the twenty-four hours of the day and night. Each hour is represented, as also the domain of each hour with its circumscribed boundary, the door of which is guarded by a huge serpent. These serpents have their various names, as "Fire-Face," "Flaming Eye," "Evil Eye," etc. The fate of Souls was decided in the third hour of the day. They were weighed by the god Thoth, who consigned them to their future abode according to the verdict of the scales. The sinful Soul was handed over to the cynocephalous ape-assessors of the infernal tribunal, who hunted and scourged it, after first changing it into a sow, or some other impure animal. The innocent Soul, on the contrary, passed in the fifth hour into the company of his fellows, whose task it was to cultivate the Elysian Fields and reap the corn of the celestial harvest, after which they took their pleasure under the guardianship of the good genii. After the fifth hour, the heavenly ocean became a vast battlefield. The gods of light pursued, captured, and bound the serpent Apapi, and at the twelfth hour they strangled him. But this triumph was not of long duration. Scarcely had the sun achieved this victory when his bark was borne by the tide into the realm of the night hours, and from that moment he was assailed 
like Virgil and Dante at the Gates of Hell, by frightful sounds and clamourings. Each circle had its voice, not to be confounded with the voices of other circles. Here the sound was as an immense humming of wasps ; yonder it was as the lamentations of women for their husbands, and the howling of she-beasts for their mates; elsewhere it was as the rolling of the thunder. The sarcophagus, as well as the walls, was covered with these scenes of joyous or sinister import. It was generally of red or black granite, and so large that it could not have been brought into the valley by way of the "Gate of the Kings." It must have been laboriously hoisted to the summit of the cliff of Dayrel-Baharee, and thence lowered to its destination. As it was put in hand last of all, it frequently happened that the sculptors had not time to finish it. When finished, however, the scenes and texts with which it was covered contained an epitome of the whole catacomb. Thus, lying in his sarcophagus, the dead man found his future destinies depicted thereon, and learned to understand the blessedness of the gods. The tombs of private persons were not often so elaborately decorated. Two tombs of the period of the Twentysixth Dynasty - that of Petamunoph at Thebes and that of Bakenrenf at Memphis-compete in this respect, however, with the royal catacombs. Their walls are not only sculptured with the text (more or less complete) of The Book of the Dead, but also with long extracts from The Book of the Opening of

* The narrow cutting in the rock described in p. 153 is called by the Arabs "Bab-el-Molook"-literally, "The Gate of the King." [Translator's note.] 
the Mouth and the religious formulæ found in the pyramids.

As every part of the tomb had its special decoration, so also it had its special furniture. Of the chapel furniture few traces have been preserved. The table of offerings, which was of stone, is generally all that remains. The objects placed in the serdab, in the passages, and in the sepulchral chamber, have suffered less from the ravages of time and the hand of man. During the Ancient Empire, the funerary portrait statues were always immured in the serdab. The sepulchral vault contained, besides the sarcophagus, head-rests of limestone or alabaster; geese carved in stone; sometimes (though rarely) a scribe's palette; generally some terra-cotta vases of various shapes; and lastly a store of food-cereals, and the bones of the victims sacrificed on the day of burial. Under the Theban Dynasties, the household goods of the dead were richer and more numerous. The $\mathrm{Ka}$ statues of his servants and family, which in former times were placed in the serdab with those of the master, were now consigned to the vault, and made on a smaller scale. On the other hand, many objects which used to be merely depicted on the walls were now represented by models, or by actual specimens. Thus we find miniature funerary boats, with crew, mummy, mourners, and friends complete; imitation bread-offerings of baked clay, erroneously called "funerary cones," stamped with the name of the deceased; bunches of grapes in glazed ware; and limestone moulds wherewith the deceased was supposed to make pottery models of oxen, birds, and fish, which should answer the purpose of 
fish, flesh, and fowl. Toilet and kitchen utensils, arms, and instruments of music abound. These are mostly broken-piously slain, in order that their souls should go hence to wait upon the soul of the dead man in the next world. Little statuettes in stone, wood, and enamel-blue, green, and white-are scattered by hundreds, and even by thousands, amid these piles of furniture, arms, and provisions. Properly speaking, they are reduced serdab-statues, destined, like their larger predecessors, to serve as bodies for the Double, and (by a later conception) for the Soul. They were at first represented clothed like the individual whose name they bore. As time went on, their importance dwindled, and their duties were limited to merely answering for their master when called, and acting as his substitutes when he was summoned by the gods to perform his share of work in the Elysian Fields. Thenceforth they were called "Respondents" ("Ushabti"), and were represented with agricultural implements in their hands. No longer clothed as the man was clothed when living, they were made in the semblance of a mummified corpse, with only the face and hands unbandaged. The so-called "canopic vases," with lids fashioned like heads of hawks, cynocephali, jackals, and men, were reserved from the time of the Eleventh Dynasty for the visceræ, which were extracted from the body by the embalmers. As for the mummy, it continued, as time went on, to be more and more enwrapped in "cartonnages," and more liberally provided with papyri and amulets; each amulet forming an essential part of its magical armour, and serving to protect its limbs and soul from destruction. 
Theoretically, every Egyptian was entitled to an eternal dwelling constructed after the plan which I have here described with its successive modifications; but the poorer folk were fain to do without those things which were the necessities of the wealthier dead. They were buried wherever it was cheapest-in old tombs which had been ransacked and abandoned; in the natural clefts of the rock; or in common pits. At Thebes, in the time of the Ramessides, great trenches dug in the sand awaited their remains. The funeral rites once performed, the grave-diggers cast a thin covering of sand over the day's mummies, sometimes in lots of two or three, and sometimes in piles which they did not even take the trouble to lay in regular layers. Some were protected only by their bandages ; others were wrapped about with palm-branches, lashed in the fashion of a game-basket. Those most cared for lie in boxes of rough-hewn wood, neither painted nor inscribed. Many are huddled into old coffins which have not even been altered to suit the size of the new occupant, or into a composite contrivance made of the fragments of three or four broken mummy-cases. As to funerary furniture, it was out of the question for such poor souls as these. A pair of sandals of painted cardboard or plaited reeds; a staff for walking along the heavenly highways; a ring of enamelled ware; a bracelet or necklace of little blue beads; a tiny image of Ptah, of Osiris, of Anubis, of Hathor, or of Bast ; a few mystic eyes or scarabs; and, above all, a twist or two of cord round the arm, the neck, the leg, or the body, intended to preserve the corpse from magical influences, -are the only possessions of the pauper dead. 


\section{CHAPTER IV.}

PAINTING AND SCULPTURE.

THE statues and bas-reliefs which decorated the temples and tombs of Ancient Egypt were for the most part painted. Coloured stones, such as granite, basalt, diorite, serpentine, and alabaster, sometimes escaped this law of polychrome; but in the case of sandstone, limestone, or wood it was rigorously enforced. If sometimes we meet with uncoloured monuments in these materials, we may be sure that the paint has been accidentally rubbed off, or that the work is unfinished. The sculptor and the painter were therefore inseparably allied. The first had no sooner finished his share of the task than the other took it up; and the same artist was often as skilful a master of the brush as of the chisel.

\section{$\S$ I. DRAWING AND COMPOSITION.}

Of the system upon which drawing was taught by the Egyptian masters, we know nothing. They had learned from experience to determine the general proportions of the body, and the invariable relations of the various parts one with another; but they never troubled themselves to tabulate those proportions, or. to reduce them to a system. Nothing in what remains 
to us of their works justifies the belief that they ever possessed a canon based upon the length of the human finger or foot. Theirs was a teaching of routine, and not of theory. Models executed by the master were copied over and over again by his pupils, till they could reproduce them with absolute exactness. That they also studied from the life is shown by the facility with which they seized a likeness, or rendered the characteristics and movements of different kinds of animals. They made their first attempts upon slabs of limestone, on drawing boards covered with a coat of red or white stucco, or on the back of old manuscripts of no value. New papyrus was too dear to be spoiled by the scrawls of tyros. Having neither pencil nor stylus, they made use of the reed, the end of which, when steeped in water, opened out into small fibres,

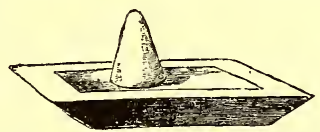

Fig. 156 . and made a more or less fine brush according to the size of the stem. The palette was of thin wood, in shape a rectangular oblong, with a groove in which to lay the brush at the lower end. At the upper end were two or more cup-like hollows, each fitted with a cake of ink; black and red being the colours most in use. A tiny pestle and mortar for colour-grinding (fig. I 56), and a cup of water in which to dip and wash the brush, completed the apparatus of the student. Palette in hand, he squatted cross-legged before his copy, and, without any kind of support for his wrist, endeavoured to reproduce the outline in black. The master looked over his work when done, and corrected the errors in red ink. 
The few designs which have come down to us are drawn on pieces of limestone, and are for the most part in sufficiently bad preservation. The British Museum possesses two or three subjects in red outline, which may perhaps have been used as copies by the decorators of some Theban tomb about the time of the Twentieth Dynasty. A fragment in the Museum of Boulak contains studies of ducks or geese in black ink; and at Turin may be seen a sketch of a half-nude female figure bending backwards, as about to turn a somersault. The lines are flowing, the movement is graceful, the modelling delicate. The draughtsman was not hampered then as now, by the rigidity of the instrument between his fingers. The reed brush attacked the surface perpendicularly; broadened, diminished, or prolonged the line at will; and stopped or turned with the utmost readiness. So supple a medium was admirably adapted to the rapid rendering of the humorous or ludicrous episodes of daily life. The Egyptians, naturally laughter-loving and satirical, were caricaturists from an early period. One of the Turin papyri chronicles the courtship of a shaven priest and a songstress of Amen in a series of spirited vignettes, while on the back of the same sheet are sketched various serio-comic scenes, in which animals parody the pursuits of civilised man. An ass, a lion, a crocodile, and an ape are represented in the act of giving a vocal and instrumental concert; a lion and a gazelle play at draughts; the Pharaoh of all the rats, in a chariot drawn by dogs, gallops to the assault of a fortress garrisoned by cats; a cat of fashion, with a flower on her head, has come to blows with a goose, 
and the hapless fowl, powerless in so unequal a contest, topples over with terror. Cats, by the way, were the favourite animals of Egyptian caricaturists. An ostrakon in the New York Museum depicts a cat of rank en grande toilette, seated in an easy chair, and a miserable Tom, with piteous mien and tail between his legs, serving her with refreshments (fig. I 57). Our catalogue of comic sketches is brief; but the abundance of pen-drawings with which certain religious works were illustrated compensates for our poverty in secular subjects. These works are "The Book of the Dead" and "The Book of Knowing That which is in Hell," which were reproduced by hundreds, according to standard copies preserved in the tem-

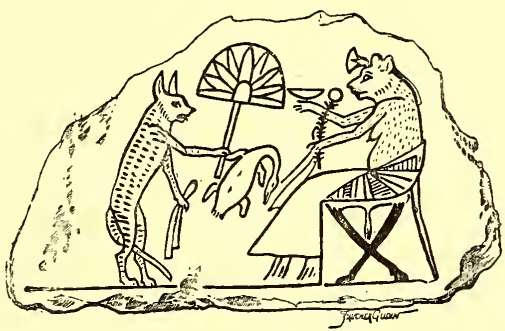

Fig. I 57. ples, or handed down through families whose hereditary profession it was to conduct the services for the dead. When making these illustrations, the artist had no occasion to draw upon his imagination. He had but to imitate the copy as skilfully as he could. Of "The Book of Knowing That which is in Hell" we have no examples earlier than the time of the Twentieth Dynasty, and these are poor enough in point of workmanship, the figures being little better than dot-and-line forms, badly proportioned and hastily scrawled. The extant specimens of "The Book of the Dead" are so numerous that a history of the art of miniature painting in 
ancient Egypt might be compiled from this source alone. The earliest date from the Eighteenth Dynasty, the more recent being contemporary with the first Cæsars. The oldest copies are for the most part remarkably fine in execution. Each chapter has its vignette representing a god in human or animal form, a sacred emblem, or the deceased in adoration before a divinity. These little subjects are sometimes ranged horizontally at the top of the text, which is written in vertical columns (fig. I 58); sometimes, like the

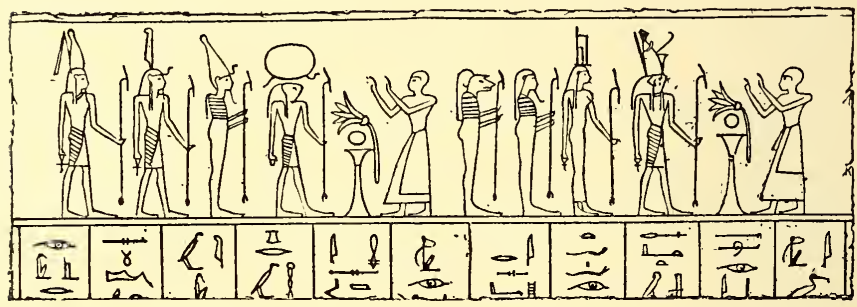

Fig. 158 .

illuminated capitals in our mediæval manuscripts, they are scattered throughout the pages. At certain points, large subjects fill the space from top to bottom of the papyrus. The burial scene comes at the beginning; the judgment of the soul about the middle; and the arrival of the deceased in the fields of Aalu* at the end of the work. In these, the artist seized the opportunity to display his skill, and show what he

* The soul of a deceased Egyptian was believed to perform a probationary pilgrimage through the lower world, in the course of which he had to perform agricultural labours in the fields of "Aalu "-an idea subsequently adopted and modified by the Greeks, who rendered "Aalu" by "Elysian." [Translator's note.] 
could do. We here see the mummy of Hunefer placed upright before his stela and his tomb (fig. I 59). The women of his family bewail him; the men and the priest present offerings. The papyri of the princes and princesses of the family of Pinotem in the

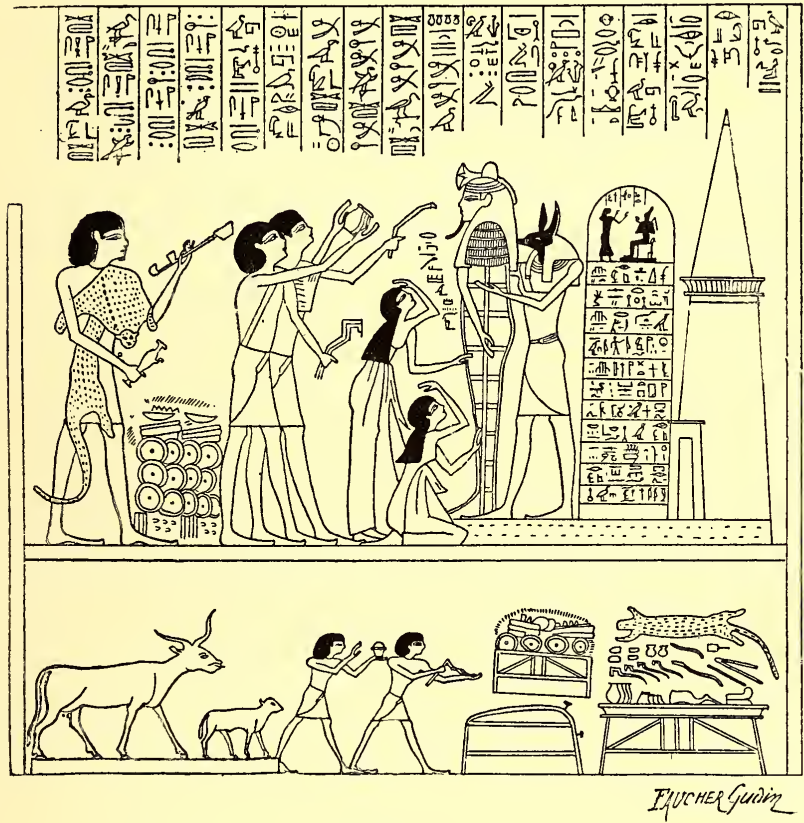

Fig. I 59 .

Museum of Boulak show that the best traditions of the art were yet in force at Thebes in the time of the Twenty-first Dynasty. Under the succeeding dynasties, that art fell into rapid decadence; and during some centuries the drawings continue to be coarse and valueless. The collapse of the Persian 
rule produced a period of Renaissance. Tombs of the Greek time have yielded papyri with vignettes carefully executed in a dry and minute style which offers a singular contrast to the breadth and boldness of the Pharaonic ages. The broad-tipped reed-pen was thrown aside for the pen with a fine point, and the scribes vied with each other as to which should trace the most attenuated lines. The details with which they overloaded their figures, the elaboration of the beard and the hair, and the folds of the garments, are sometimes so minute that it is scarcely possible to distinguish them without a magnifying glass. Precious as these documents are, they give a very insufficient idea of the ability and technical methods of the artists of ancient Egypt. It is to the walls of their temples and tombs that we must turn, if we desire to study their principles of composition.

Their conventional system differed materially from our own. Man or beast, the subject was never anything but a profile relieved against a flat background. Their object, therefore, was to select forms which presented a characteristic outline capable of being reproduced in pure line upon a plane surface. As regarded animal life, the problem was in no wise complicated. The profile of the back and body, the head and neck, carried in undulating lines parallel with the ground, were outlined at one sweep of the pencil. The legs also are well detached from the body. The animals themselves are lifelike, each with the gait and action and flexion of the limbs peculiar to its species. The slow and measured tread of the ox; the short step, the meditative ear, the ironical mouth of the ass; the 
abrupt little trot of the goat, the spring of the hunting greyhound, are all rendered with invariable success of outline and expression. Turning from domestic animals to wild beasts, the perfection of treatment is the same. The calm strength of the lion in repose, the stealthy and sleepy tread of the leopard, the grimace of the ape, the slender grace of the gazelle and the antelope, have never been better expressed than in Egypt. But it was not so easy to project man-the whole manupon a plane surface without some departure from nature. A man cannot be satisfactorily reproduced by means of mere lines, and a profile outline necessarily excludes too much of his person. The form of the forehead and the nose, the curvature of the lips, the cut of the ear, disappear when the head is drawn full face; but, on the other hand, it is necessary that the bust should be presented full face, in order to give the full development of the shoulders, and that the two arms may be visible to right and left of the body. The contours of the trunk are best modelled in a threequarters view, whereas the legs show to most advantage when seen sidewise. The Egyptians did not hesitate to combine these contradictory points of view in one single figure. The head is almost always given in profile, but is provided with a full-face eye and placed upon a full-face bust. The full-face bust adorns a trunk seen from a three-quarters point of view, and this trunk is supported upon legs depicted in profile. Very seldom do we meet with figures treated according to our own rules of perspective. Most of the minor personages represented in the tomb of Khnumhotep seem, however, to have made an effort to emancipate 
themselves from the law of malformation. Their bodies are given in profile, as well as their heads and legs; but they thrust forward first one shoulder and then the other, in order to show both arms (fig. I60), and the effect is not happy. Yet, if we examine the treatment of the farm servant who is cramming a goose, and, above all, the figure of the standing man who throws his weight upon the neck of a gazelle to make it kneel down (fig. I6I), we shall see that the action of the arms and hips is correctly rendered, that the form of the back is quite right, and that the prominence of the chest -thrown forward in proportion as the shoulders and

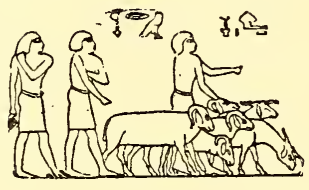

Fig. I6o.

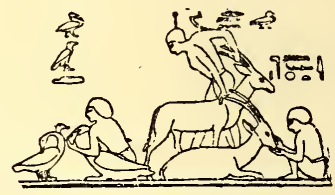

Fig. 16 I.

arms are thrown back-is drawn without any exaggeration. The wrestlers of the Beni Hassan tombs, the dancers and servants of the Theban catacombs, attack, struggle, posture, and go about their work with perfect naturalness and ease (fig. I62). These, however, are exceptions. 'Tradition, as a rule, was stronger than nature, and to the end of the chapter, the Egyptian masters continued to deform the human figure. Their men and women are actual monsters from the point of view of the anatomist; and yet, after all, they are neither so ugly nor so ridiculous as might be supposed by those who have seen only the wretched copies so often made by our modern artists. The wrong parts 
are joined to the right parts with so much skill that they seem to have grown there. The natural lines and the fictitious lines follow and complement each other so ingeniously, that the former appear to give rise of necessity to the latter. The conventionalities of Egyptian art once accepted, we cannot sufficiently admire the technical skill displayed by the draughtsman. His line was pure, firm, boldly begun, and as boldly prolonged. Ten or twelve strokes of the brush sufficed to outline a figure the size of life. The whole head,

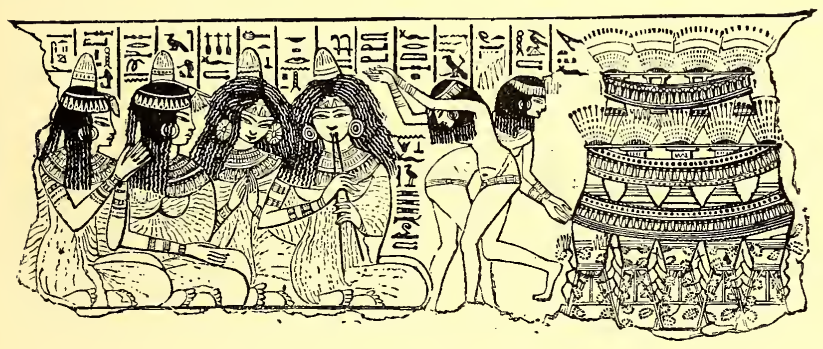

Fig. I62.

from the nape of the neck to the rise of the throat above the collar-bone, was executed at one sweep. Two long undulating lines gave the external contour of the body from the armpits to the ends of the feet. Two more determined the outlines of the legs, and two the arms. The details of costume and ornaments, at first but sumrnarily indicated, were afterwards taken up one by one, and minutely finished. We may almost count the locks of the hair, the plaits of the linen, the inlayings of the girdles and bracelets. This mixture of artless science and intentional awkwardness, of rapid execution and patient finish, excludes neither 
elegance of form, nor grace of attitude, nor truth of movement. These personages are of strange aspect, but they live; and to those who will take the trouble to look at them without prejudice, their very strangeness has a charm about it which is often lacking to works more recent in date and more strictly true to nature.

We admit, then, that the Egyptians could draw. Were they, as it has been ofttimes asserted, ignorant of the art of composition? We will take a scene at hazard from a Theban tomb-that scene which represents the funerary repast offered to Prince Horemheb

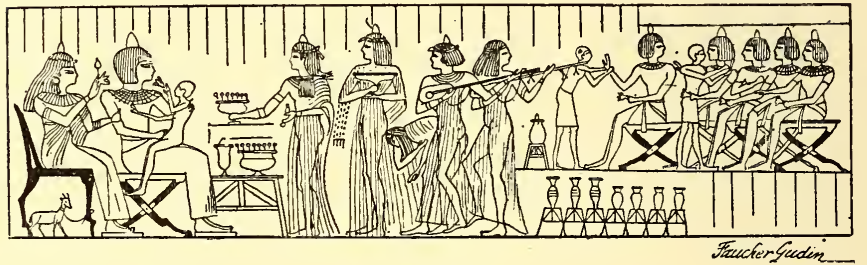

Fig. 163 .

by the members of his family (fig. I63). The subject is half ideal, half real. The dead man, and those belonging to him who are no longer of this world, are depicted in the society of the living. They are present, yet aloof. They assist at the banquet, but they do not actually take part in it. Horemheb sits on a folding stool to the left of the spectator. He dandles on his knee a little princess, daughter of Amenhotep III., whose foster-father he was, and who died before him. His mother, Souit, sits at his right hand a little way behind, enthroned in a large chair. She holds his arm with her left hand, and with the right she offers him 
a lotus blossom and bud. A tiny gazelle which was probably buried with her, like the pet gazelle discovered beside Queen Isi-em-Kheb in the hiding-place at Dayrel-Baharee, is tied to one of the legs of the chair. This ghostly group is of heroic size, the rule being that gods are bigger than men, kings bigger than their subjects, and the dead bigger than the living. Horemheb, his mother, and the women standing before them, occupy the front level, or foreground. The relations and friends are ranged in line facing their deceased ancestors, and appear to be talking one with another. The feast has begun. The jars of wine and beer, placed in rows upon wooden stands, are already unsealed. Two young slaves rub the hands and necks of the living guests with perfumes taken from an alabaster vase. Two women dressed in robes of ceremony present offerings to the group of dead, consisting of vases filled with flowers, perfumes, and grain. These they place in turn upon a square table. Three others dance, sing, and play upon the lute, by way of accompaniment to those acts of homage. In the picture, as in fact, the tomb is the place of entertainment. There is no other background to the scene than the wall covered with hieroglyphs, along which the guests were seated during the ceremony. Elsewhere, the scene of action, if in the open country, is distinctly indicated by trees and tufts of grass; by red sand, if in the desert; and by a maze of reeds and lotus plants, if in the marshes. A lady of quality comes in from a walk (fig. I64). One of her daughters, being athirst, takes a long draught from a "goullah;" two little naked children with shaven heads, a boy and a girl, who ran to meet their mother 


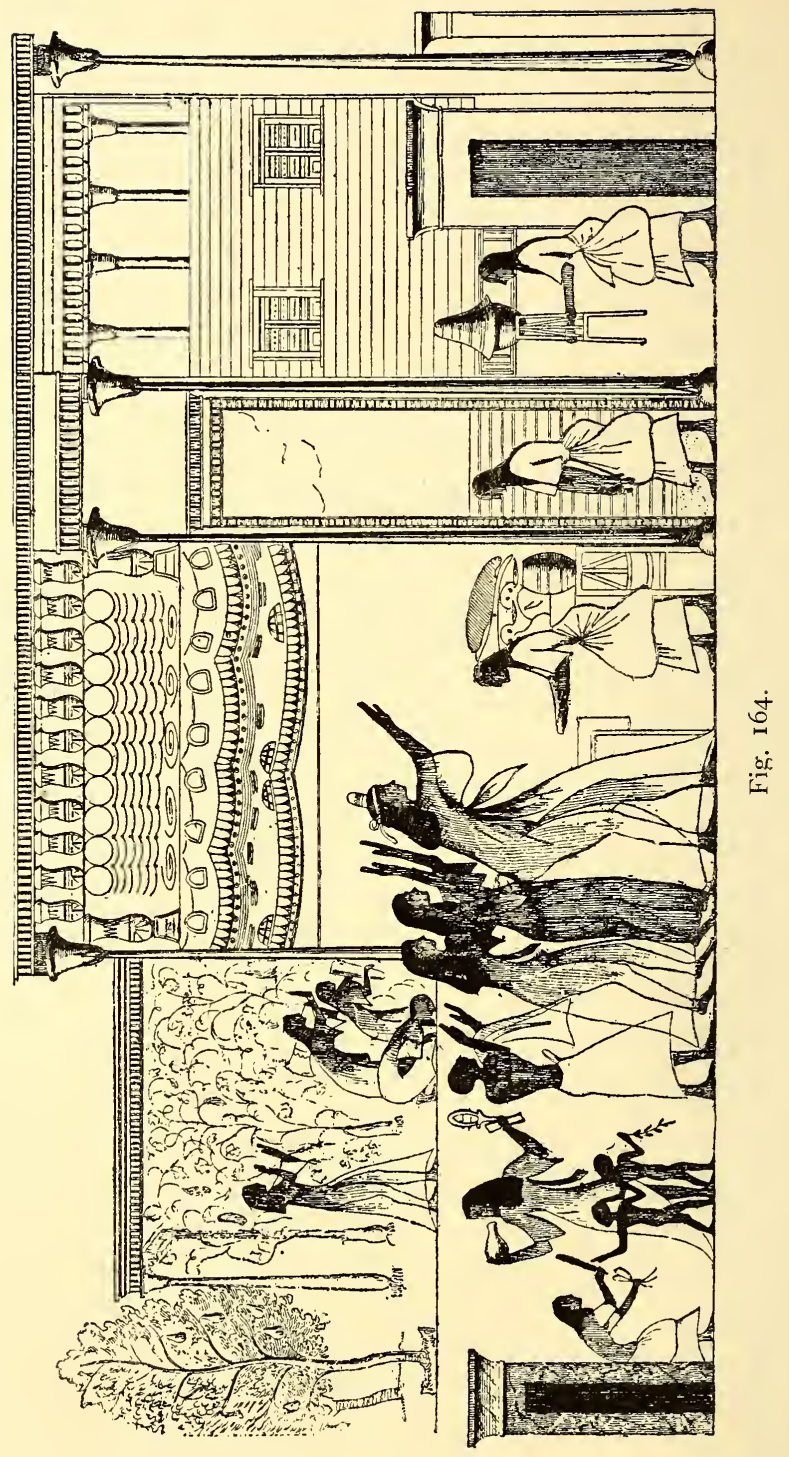


at the gate, are made happy with toys brought home and handed to them by a servant. A trellised enclosure covered with vines, and trees laden with fruit, are shown above; yonder, therefore, is the garden, but the lady and her daughters have passed through it without stopping, and are now indoors. The front of the house is half put in and half left out, so that we may observe what is going on inside. We accordingly see three attendants hastening to serve their mistresses with refreshments. The picture is not badly composed, and it would need but little alteration if transferred to a modern canvas. The same old awkwardness, or rather the same old obstinate custom, which compelled the Egyptian artist to put a profile head upon a full-face bust, has, however, prevented him from placing his middle distance and background behind his foreground. He has, therefore, been reduced to adopt certain more or less ingenious contrivances, in order to make up for an almost complete absence of perspective.

Again, when a number of persons engaged in the simultaneous performance of any given act were represented on the same level, they were isolated as much as possible, so that each man's profile might not cover that of his neighbour. When this was not done, they were arranged to overlap each other, and this, despite the fact that all stood on the one level; so that they have actually but two dimensions and no thickness. A herdsman walking in the midst of his oxen plants his feet upon precisely the same ground-line as the beast which interposes between his body and the spectator. The most distant soldier of a company which advances in good marching order to the sound of the trumpet, 
has his head and feet on exactly the same level as the head and feet of the foremost among his comrades (fig. I65). When a squadron of chariots defiles before Pharaoh, one would declare that their wheels all ran in

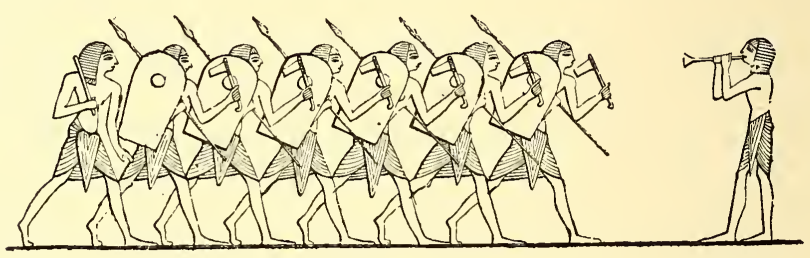

Fig. 165 .

the self-same ruts, were it not that the body of the first chariot partly hides the horses by which the second chariot is drawn. In these examples the people and objects are, either accidentally or naturally, placed so

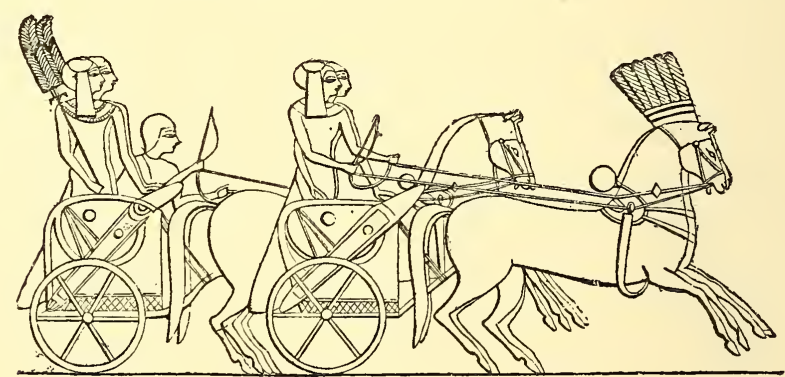

Fig. I66.

near together, that the anomaly does not strike one as too glaring. In taking these liberties, the Egyptian artist but anticipated a contrivance adopted by the Greek sculptor of a later age. Elsewhere, the Egyptian has occasionally approached nearer to truth of treat- 
ment. The archers of Rameses III. at Medinet-Haboo make an effort which is almost successful, to present themselves in perspective. The row of helmets slopes downwards, and the row of bows slopes upward, with praiseworthy regularity; but the men's feet are all on the same level, and do not, therefore, follow the direction of the other lines* (fig. I67). This mode of representation is not uncommon during the Theban period. It was generally adopted when men or animals, ranged in line, had to be shown in the act of doing the same thing; but it was subject to the grave drawback (or what was in Egyptian eyes the grave drawback) of showing the body of the first man only, and of almost entirely hiding the rest of the figures. When, therefore, it was found impossible to range all upon the same level without hiding

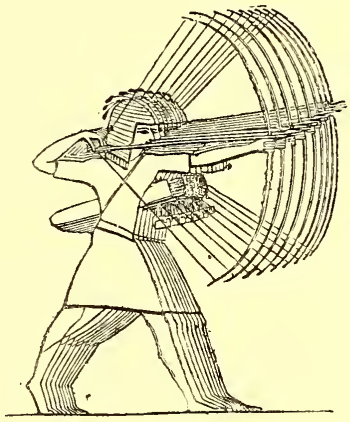

Fig. 167. some of their number, the artist frequently broke his masses up into groups, and placed one above the other on the same vertical plane. Their height in no wise depends on the place they occupy in the perspective of the tableau, but only upon the number of rows required by the artist to carry out his idea. If two rows of figures are sufficient, he divides his

* The upper line of the bows should, however, incline downwards, like the line of helmets; and the arrows, being on the level of the point of sight, should of course be strictly horizontal. [Translator's note.] 
space horizontally into equal parts; if he requires three rows, he divides it into three parts; and so on. When, however, it is a

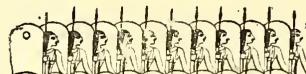
oreperente

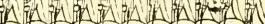
- ERerere.

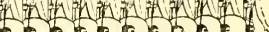

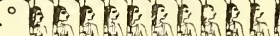
- cererese - B peterer.

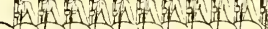

ODCOCE E Ant

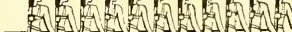

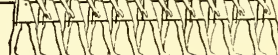
question of mere accessories, they are made out upon a smaller scale. Secondary scenes are generally separated by a horizontal line, but this line is not indispensable. When masses of figures formed in regular order had to be shown, the vertical planes lapped over, so to speak, according to the caprice of the limner. At the Fig. 168. battle of Kadesh, the files of Egyptian infantry rise man above man, waist high, from top to bottom of the phalanx (fig. I68); while those of the Hittite battalions show but one head above another (fig. I69).

It was not only in their treatment of men and animals that the Egyptians allowed themselves this latitude. Houses, trees, land and water, were as freely misrepresented. An oblong rectangle placed upright,

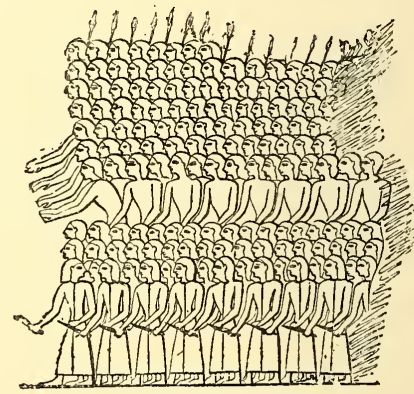

Fig. 169. or on its side, and covered with regular zigzags, represents a canal. Lest one should be in doubt as to its meaning, fishes and crocodiles are put in, to show that 
it is water, and nothing but water. Boats are seen floating upright upon this edgewise surface; the flocks ford it where it is shallow; and the angler with his line marks the spot where the water ends and the bank begins. Sometimes the rectangle is seen suspended like a framed picture, at about half way of the height of five or six palm trees (fig. I70); whereby we are given to understand a tank bordered on both sides by trees. Sometimes, again, as in the tomb of Rekhmara, the trees are laid down in rows round the four sides of a square pond, while a profile boat conveying a dead man in his shrine, hauled by slaves also shown in profile, floats on the vertical surface of the water. The Theban catacombs of the Ramesside period supply abun-

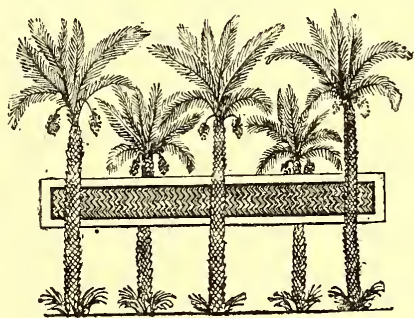

Fig. I70. dant examples of contrivances of this kind; and, having noted them, we end by not knowing which most to wonder at-the obstinacy of the Egyptians in not seeking to discover the natural laws of perspective, or the inexhaustible wealth of resource which enabled them to invent so many false relations between the various parts of their subjects.

When employed upon a very large scale, their methods of composition shock the eye less than when applied to small subjects. We instinctively feel that even the ablest artist must sometimes have played fast and loose with the laws of perspective, if tasked to cover the enormous surfaces of Egyptian pylons. 
Hence the unities of the subject are never strictly observed in these enormous bas-reliefs. The main object being to perpetuate the memory of a victorious Pharaoh, that Pharaoh necessarily plays the leading part; but instead of selecting from among his striking deeds some one leading episode pre-eminently calculated to illustrate his greatness, the Egyptian artist

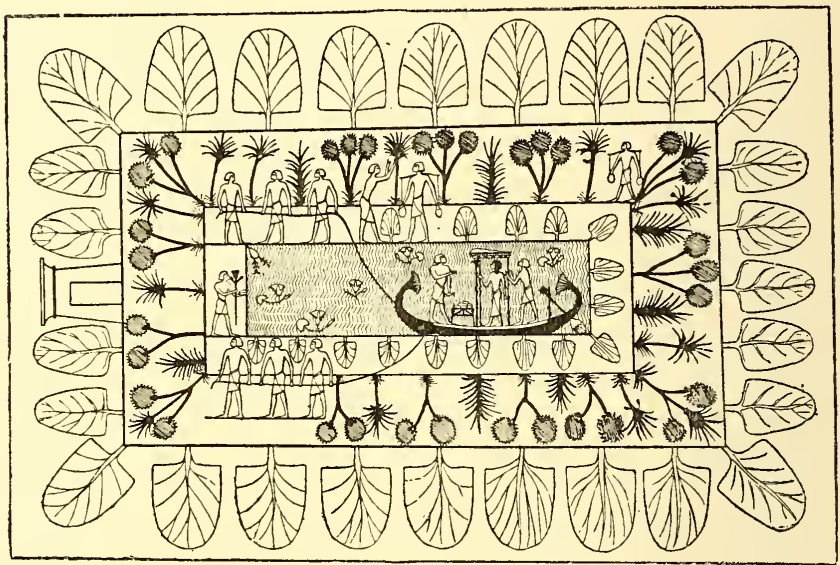

Fig. 17 I.

delighted to present the successive incidents of his campaigns at a single coup d'cil. Thus treated, the pylons of Luxor and the Ramesseum show a Syrian night attack upon the Egyptian camp; a seizure of spies sent by the prince of the Kheta for the express purpose of being caught and giving false intelligence of his movements; the king's household troops surprised and broken by the Khetan chariots; the battle of Kadesh and its various incidents, so furnishing us, as 
it were, with a series of illustrated despatches of the Syrian campaign undertaken by Rameses II. in the fifth year of his reign. After this fashion precisely did the painters of the earliest Italian schools depict within the one field, and in one uninterrupted sequence, the several episodes of a single narrative. The scenes

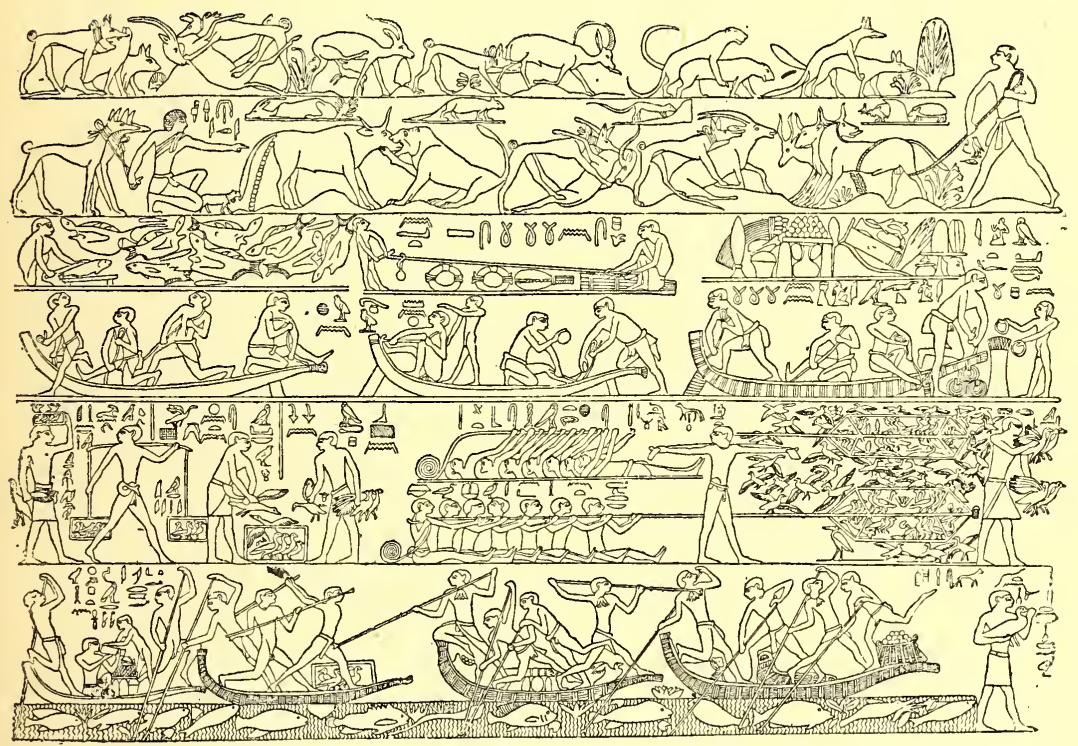

Fig. I72.

are irregularly dispersed over the surface of the wall, without any marked lines of separation, and, as with the bas-reliefs upon the column of Trajan, one is often in danger of dividing the groups in the wrong place, and of confusing the characters. This method is reserved almost exclusively for official art. In the interior decoration of temples and tombs, the various 
parts of the one subject are distributed in rows ranged one above the other, from the ground line to the cornice. Thus another difficulty is added to the number of those which prevent us from understanding the style and intention of Egyptian design. We often imagine that we are looking at a series of isolated scenes, when in fact we have before our eyes the disjecta membra of a single composition. Take, for example, one wall-side of the tomb of Ptah-hotep at Sakkarah (fig. I72). If we would discover the link which divides these separate scenes, we shall do well to compare this wall-subject with the mosaic of Palestrina (fig. I73), a monument of Græco-Roman time which represents almost the same scenes, grouped, however, after a style more familiar to our ways of seeing and thinking. The Nile occupies the immediate foreground of the picture, and extends as far as the foot of the mountains in the distance. Towns rise from the water's edge ; and not only towns, but obelisks, farm-houses, and towers of Græco-Italian style, more like the buildings depicted in Pompeian landscapes than the monuments of the Pharaohs. Of these buildings, only the large temple in the middle distance to the right of the picture, with its pylon gateway and its four Osirian colossi, recalls the general arrangement of Egyptian architecture. To the left, a party of sportsmen in a large boat are seen in the act of harpooning the hippopotamus and crocodile. To the right, a group of legionaries, drawn up in front of a temple and preceded by a priest, salute a passing galley. Towards the middle of the foreground, in the shade of an arched trellis thrown across a small branch 
of the Nile, some half-clad men and women are singing and carousing. Little papyrus skiffs, each rowed by a single boatman, and other vessels fill the vacant spaces of the composition. Behind the buildings we see the

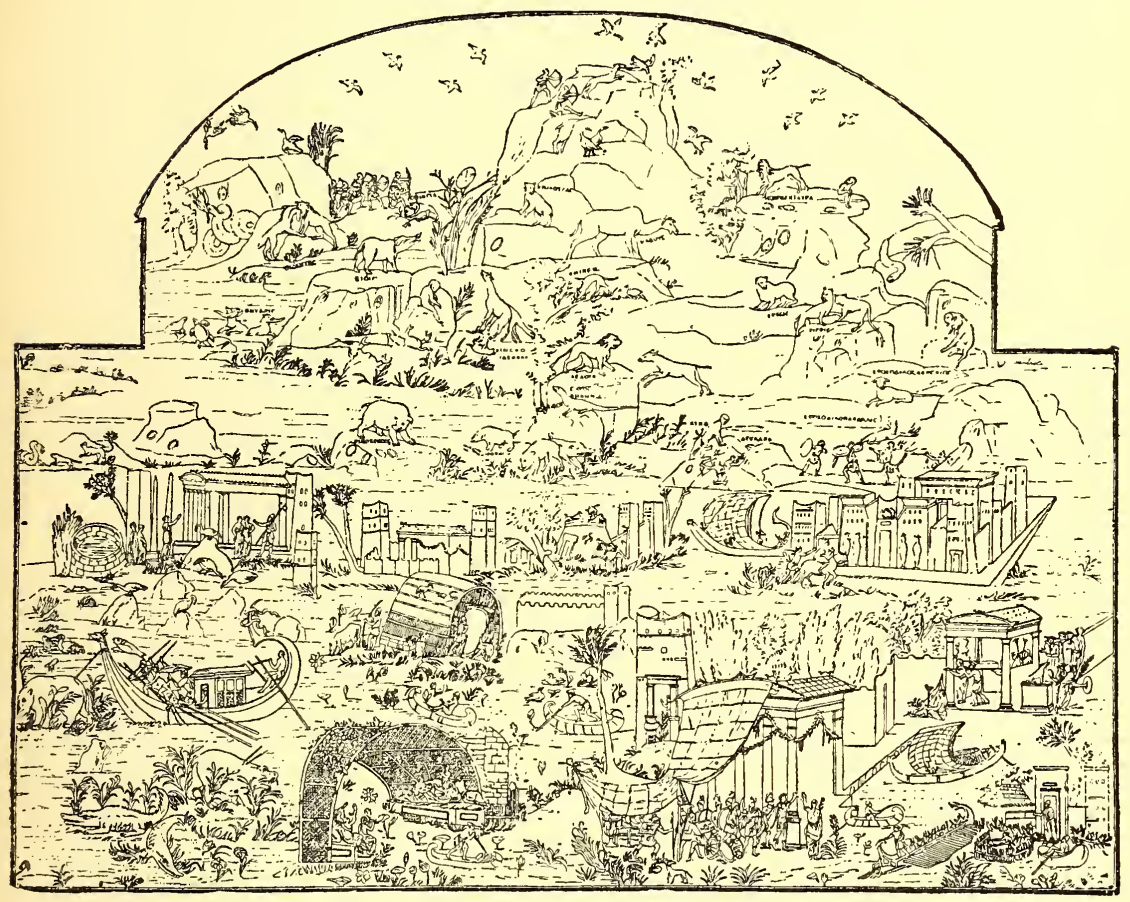

Fig. 173 .

commencement of the desert. The water forms large pools at the base of overhanging hills, and various animals, real or imaginary, are pursued by shavenheaded hunters in the upper part of the picture. Now, precisely after the manner of the Roman mosaicist, the old 
Egyptian artist placed himself, as it were, on the Nile, and reproduced all that lay between his own standpoint and the horizon. In the wall-painting (fig. I72) the river flows along the line next the floor, boats come and go, and boatmen fall to blows with punting poles and gaffs. In the division next above, we see the river bank and the adjoining flats, where a party of slaves, hidden in the long grasses, trap and catch birds. Higher still, boat-making, rope-making, and fish-curing are going on. Finally, in the highest register of all, next the ceiling, are depicted the barren hills and undulating plains of the desert, where greyhounds chase the gazelle, and hunters trammel big game with the lasso. Each longitudinal section corresponds, in fact, with a plane of the landscape ; but the artist, instead of placing his planes in perspective, has treated them separately, and placed them one above the other. We find the same disposition of the parts in all Egyptian tomb paintings. Scenes of inundation and civil life are ranged along the base of the wall, mountain subjects and hunting scenes being invariably placed high up. Sometimes, interposed between these two extremes, the artist has introduced subjects dealing with the pursuits of the herdsmen, the field labourer, and the craftsman. Elsewhere, he suppresses these intermediary episodes, and passes abruptly from the watery to the sandy region. Hence, the mosaic of Palestrina and the tombpaintings of Pharaonic Egypt reproduce the same group of subjects, treated after the conventional styles and methods of two different schools of art. Like the mosaic, the wall scenes of the tomb formed, not a series of independent scenes, but an ordinary compo- 
sition, the unity of which is readily recognised by such as are skilled to read the art-language of the period.

\section{TECHNICAL PROCESSES.}

The preparation of the surface about to be decorated demanded much time and care. Seeing how imperfect were the methods of construction, and how impossible it was for the architect to ensure a perfectly level surface for the facing stones of his temple-walls and pylons, the decorator had perforce to accommodate himself to a surface slightly rounded in some places and slightly hollowed in others. Even the blocks of which it was formed were scarcely homogeneous in texture. The limestone strata in which the Theban catacombs were excavated were almost always interspersed with flint nodules, fossils, and petrified shells. These faults were variously remedied according as the decoration was to be sculptured or painted. If painted, the wall was first roughly levelled, and then overlaid with a coat of black clay and chopped straw, similar to the mixture used for brick-making. If sculptured, then the artist had to arrange his subject so as to avoid the inequalities of the stone as much as possible. When these occurred in the midst of the figure subjects, and if they did not offer too stubborn a resistance to the chisel, they were simply worked over; otherwise the piece was cut out and a new piece fitted in, or the hole was filled up with white cement. This mending process was no trifling matter. We could point to tomb-chambers where every wall is thus inlaid to the extent of one quarter of its surface. The preliminary work being done, the whole was 
covered with a thin coat of fine plaster mixed with white of egg, which hid the mud-wash or the piecing, and prepared a level and polished surface for the pencil of the artist. In chambers, or parts of chambers, which have been left unfinished, and even in the quarries, we constantly find sketches of intended bas-reliefs, outlined in red or black ink. The copy was generally executed upon a small scale, then squared off, and transferred to the wall by the pupils and assistants of the master.

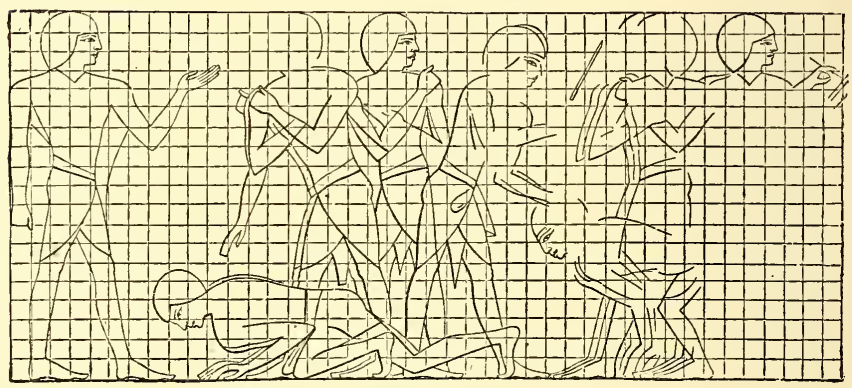

Fig. 174 .

As in certain scenes carefully copied by Prisse from the walls of Theban tombs, the subject is occasionally indicated by only two or three rapid strokes of the reed (fig. I 74). Elsewhere, the outline is fully made out, and the figures only await the arrival of the sculptor. Some designers took pains to determine the position of the shoulders, and the centre of gravity of the bodies, by vertical and horizontal lines, upon which, by means of a dot, they noted the height of the knee, the hips, and other parts (fig. I75). Others again, more selfreliant, attacked their subject at once, and drew in the 
figures without the aid of guiding points. Such were the artists who decorated the catacomb of Seti I., and the southern walls of the temple of Abydos. Their outlines are so firm, and their facility is so surprising, that they have been suspected of stencilling; but no one who has closely examined their figures, or who has taken the trouble to measure them with a compass, can maintain that opinion. The forms of some are slighter than the forms of others; while in some the contours of the chest are more accentuated, and the legs farther apart, than in others. The master had little to correct in the work of these subordinates. Here and there he made a head more erect, accentuated or modified the outline of a knee, or improved some detail of arrangement. In one instance, however, at Kom

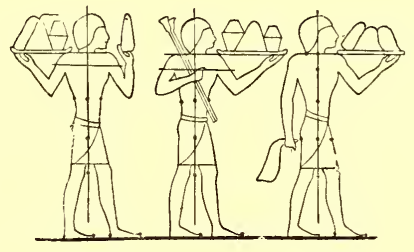

Fig. 175 . Ombo, on the ceiling of a Græco-Roman portico, some of the divinities had been falsely oriented, their feet being placed where their arms should have been. The master consequently outlined them afresh, and on the same squared surface, without effacing the first drawing. Here, at all events, the mistake was discovered in time. At Karnak, on the north wall of the hypostyle hall, and again at Medinet Haboo, the faults of the original design were not noticed till the sculptor had finished his part of the work. The figures of Seti I. and Rameses III. were thrown too far back, and threatened to overbalance themselves; so they were smoothed over with cement 
and cut anew. Now, the cement has flaked off, and the work of the first chisel is exposed to view. Seti I. and Rameses III. have each two profiles, the one very lightly marked, the other boldly cut into the surface of

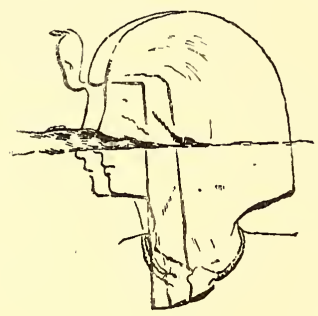

Fig. 176 . the stone (fig. I76).

The sculptors of ancient Egypt were not so well equipped as those of our own day. A kneeling scribe in limestone at the Boulak Museum has been carved with the chisel, the grooves left by the tool being visible on his skin. A statue in grey serpentine, in the same collection, bears traces of the use of two different tools, the body being spotted all over with point-marks, and the unfinished head being blocked out splinter by splinter with a small hammer. Similar observations, and the study of the monuments, show that the drill (fig. I77), the toothed-chisel, and the gouge were also employed. There have been endless discussions as to whether these tools were of iron or of bronze. Iron, it is argued, was deemed impure. No one could make use of it, even for the basest needs of daily life,

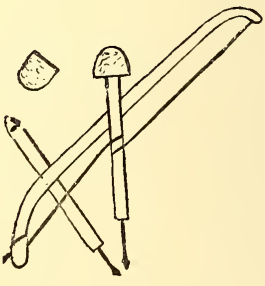

Fig. 177 . without incurring a taint prejudicial to the soul both in this world and the next. But the impurity of any given object never sufficed to prevent the employment of it when required. Pigs also were impure; yet the Egyptians bred them. They bred them, indeed, so 
abundantly in certain districts, that our worthy Herodotus tells how the swine were turned into the fields after seed-sowing, in order that they might tread in the grain. So also iron, like many other things in Egypt, was pure or impure according to circumstances. If some traditions held it up to odium as an evil thing, and stigmatised it as the "bones of Typhon," other traditions equally venerable affirmed that it was the very substance of the canopy of heaven. So authoritative was this view, that iron was currently known as "Ba-en-pet," or the celestial metal. $\dagger$ The few fragments of tools which have been found in the masonry of the pyramids are of iron, not bronze; and if ancient iron objects are nowadays of exceptional rarity as compared with ancient bronze objects, it is because iron differs from bronze, inasmuch as it is not protected from destruction by its oxide. Rust speedily devours it, and it needs a rare combination of favourable circumstances to preserve it intact. If, however, it is quite certain that the Egyptians were acquainted with, and made use of, iron, it is no less certain that they were wholly unacquainted with steel. This being the case, one asks how they can possibly have dealt at will upon the hardest rocks, even upon such as we ourselves hesitate to attack, namely, diorite, basalt, and the granite of Syene. The manufacturers of antiquities who sculpture granite for the benefit of tourists, have found a simple solution of this problem. They work with somie

* The late T. Deveria ingemiously conjectured that "Ba-en-pet" (iron of heaven) might mean the ferruginous substance of meteoric stones. See Mélanges d'Archéologie Egyptienne et Assyrienne, vol. i. [Translator's note.] 
twenty common iron chisels at hand, which after a very few turns are good for nothing. When one is blunted, they take up another, and so on till the stock is exhausted. Then they go to the forge, and put their tools into working order again. The process is neither so long nor so difficult as might be supposed. In the Boulak Museum there may be seen a life-size head, which was produced from a block of black and red granite in less than a fortnight by one of the best forgers in Luxor. I have no doubt that the ancient Egyptians worked in precisely the same way, and mastered the hardest stones by the use of iron. The means once discovered, practice soon taught them the manual methods by which their labour might be lightened, and their tools made to yield results as delicate and subtle as those which we achieve with our own. As soon as the learner knew how to manage the point and the mallet, his master set him to copy a series of graduated models representing an animal in various stages of completion, or a part of the human body, or the whole human body, from the first rough sketch to the finished design (fig. I 78). Every year, these models are found in sufficient number to establish examples of progressive series. Apart from isolated specimens which are picked up everywhere, the Boulak collection contains a set of fifteen from Sakkarah, forty-one from Tanis, and a dozen from Thebes and Medinet Haboo. They were intended partly for the study of bas-reliefs, partly for the study of sculpture proper; and they reveal the method in use for both.

The Egyptians treated bas-relief in three ways: either as a simple engraving executed by means of 
incised lines; or by cutting away the surface of the stone round the figure, and so causing it to stand out

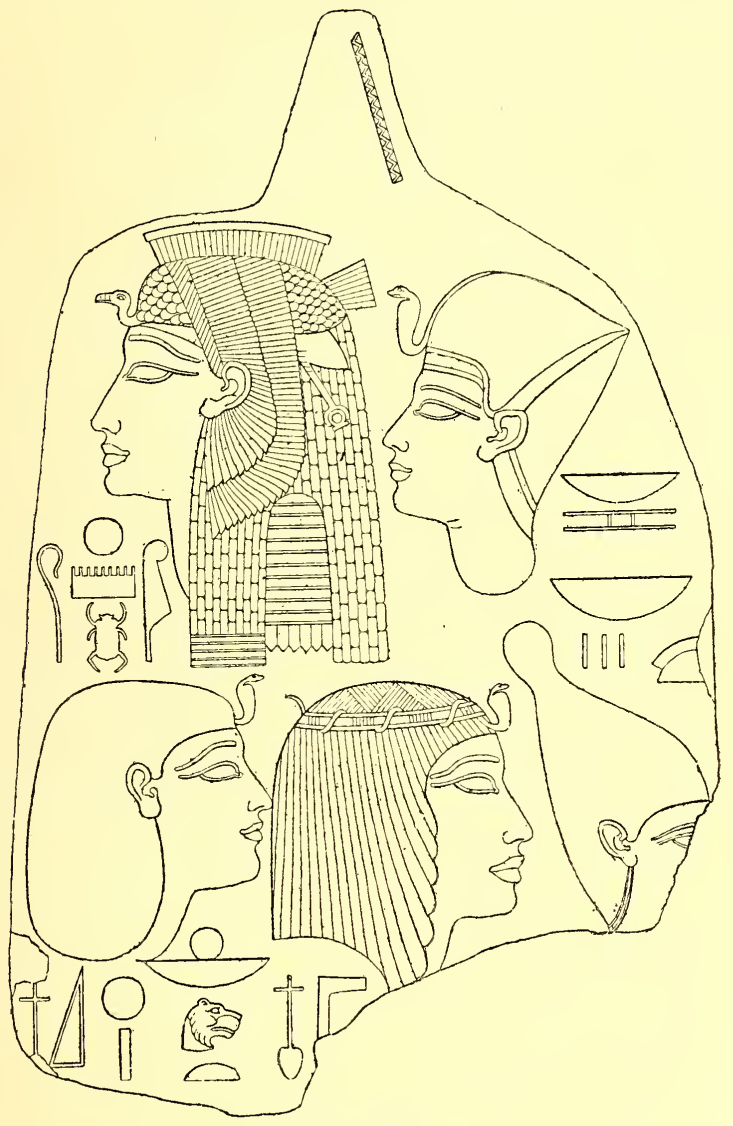

Fig. 178 .

in relief upon the wall ; or by sinking the design below the wall-surface and cutting it in relief at the bottom of the hollow. The first method has the advantage of 
being expeditious, and the disadvantage of not being sufficiently decorative. Rameses III. made use of it in certain parts of his temple at Medinet Haboo; but, as a rule, it was preferred for stelæ and small monuments. The last-named method lessened not only the danger of damage to the work, but the labour of the workman. It evaded the dressing down of the background, which was a distinct economy of time, and it left no projecting work on the face of the surface; the design being thus sheltered from accidental blows. The intermediate process was, however, generally adopted, and appears to have been taught in the schools by preference. The models were little rectangular tablets, squared off in order that the scholar might enlarge or reduce the scale of his subject without departing from the traditional proportions. Some of these models are wrought on both sides; but the greater number are sculptured on one side only. Sometimes the design represents a bull; sometimes the head of a cynocephalous ape, of a ram, of a lion, of a divinity. Occasionally, we find the subject in duplicate, side by side, being roughly blocked out to the left, and highly finished to the right. In no instance does the relief exceed a quarter of an inch, and it is generally even less. Not but that the Egyptians sometimes cut boldly into the stone. At Medinet Haboo and Karnak -on the higher parts of these temples, where the work is in granite or sandstone, and exposed to full daylightthe bas-relief decoration projects full $6 \frac{3}{8}$ inches above the surface. Had it been lower, the tableaux would have been, as it were, absorbed by the flood of light poured upon them, and to the eye of the spectator would have presented only a confused network of lines. The models 
designed for the study of the round are even more instructive than the rest. Some which have come down to us are plaster casts of familiar subjects. The head, the arms, the legs, the trunk, each part of the body, in short, was separately cast. If a complete figure were wanted, the disjecta membra were put together, and the result was a statue of a man, or of a woman, kneeling, standing, seated, squatting, the arms extended or falling passively by the sides. This curious collection was discovered at Tanis, and dates probably from Ptolemaic times.* Models of the Pharaonic ages are in soft limestone, and nearly all represent portraits of reigning sovereigns. These are best described as cubes measuring about ten inches each way. The work was begun by covering one face of a cube with a network of lines crossing each other at right angles; these regulated the relative position of the features. Then the opposite side was attacked, the distances being taken from the scale on the reverse face. A mere oval was designed on this first block; a projection in the middle and a depression to right and left, vaguely indicating the whereabouts of nose and eyes. The forms become more definite as we pass from cube to cube, and the face emerges by degrees. The limit of the contours is marked off by parallel lines cut vertically from top to bottom. The angles were next cut away and smoothed down, so as to bring out the forms. Gradually the features become disengaged from the block, the

* A similar collection was found by Mr. Petrie at Tell Nebesheh (the ancient Egyptian city of "Am"), in I886, during his excavations for the Egypt Exploration Fund. See Mr. Petrie's forthcoming volume "Tanis. Part II." [Translator's note.] 
eye looks out, the nose gains refinement, the mouth is developed. When the last cube is reached, there remains nothing to finish save the details of the headdress and the basilisk on the brow. No scholar's model in granite or basalt has yet been found; but the Egyptians, like our monumental masons, always kept a stock of half-finished statues in hard stone, which could be turned out complete in a few hours. The hands, feet, and bust needed only a few last touches; but the heads were merely blocked out, and the clothing left in the rough. Half a day's work then sufficed to transform the face into a portrait of the purchaser, and to give the last new fashion to the kilt. The discovery of some two or three statues of this kind has shown us as much of the process as a series of teacher's models might have done. Volcanic rocks could not be cut with the continuity and regularity of limestone. The point only could make any impression upon these obdurate materials. When, by force of time and patience, the work had thus been finished to the degree required, there would often remain some little irregularities of surface, due, for example, to the presence of nodules and heterogeneous substances, which the sculptor had not ventured to attack, for fear of splintering away part of the surrounding surface. In order to remove these irregularities, another tool was employed; namely, a stone cut in the form of an axe. Applying the sharp edge of this instrument to the projecting nodule, the artist struck it with a round stone in place of a mallet. A succession of carefully calculated blows with these rude tools pulverised the obtrusive knob, which disappeared in dust. All minor defects being corrected, the 
monument still looked dull and unfinished. It was necessary to polish it, in order to efface the scars of point and mallet. This was a most delicate operation ; one slip of the hand, or a moment's forgetfulness, being enough to ruin the labour of many weeks. The dexterity of the Egyptian craftsman was, however, so great that accidents rarely happened. The Sebekemsaf of Boulak, the colossal Rameses II. of Luxor, challenge the closest examination. The play of light upon the surface may at first prevent the eye from apprehending the fineness of the work; but, seen under favourable circumstances, the details of knee and chest, of shoulder and face, prove to be no less subtly rendered in granite than in limestone. Excess of polish has no more spoiled the statues of ancient Egypt than it spoiled those of the sculptors of the Italian Renaissance.

On leaving the hands of the sculptor, the work passed into the hands of the painter. It would have been deemed imperfect, if left to show the colour of the stone in which it was cut. Egyptian statues were painted from head to foot. In bas-relief, the background was left untouched and only the figures were coloured. The Egyptians had more pigments at their disposal than is commonly supposed. The more ancient painters' palettes - and we have some which date from the Fifth Dynasty - have compartments for yellow, red, blue, brown, white, black, and green. Others, of the time of the Eighteenth Dynasty, provide for three varieties of yellow, three of brown, two of red, two of blue, and two of green ; making in all some fourteen or sixteen different tints. Black was obtained by calcining the bones of animals. The other substances employed in painting 
were indigenous to the country. The white is made of plaster, mixed with albumen or honey; the yellows are ochre, or sulphuret of arsenic, the orpiment of our modern artists; the reds are ochre, cinnabar, or vermilion; the blues are pulverised lapis-lazuli, or sulphate of copper. If the substance was rare or costly, a substitute drawn from the products of native industry was found. Lapis-lazuli, for instance, was replaced by blue glass made with an admixture of sulphate of copper, and this was reduced to an impaipable powder. The painters kept their colours in tiny bags, and, as required, mixed them with water containing a little adraganth gum. They laid them on by meahs of a reed, or a more or less fine hair brush. When well prepared, these pigments are remarkably solid, and have changed but little during the lapse of ages. The reds have darkened, the greens have faded, the blues have turned somewhat green or grey; but this is only on the surface. If that surface is scraped off, the colour underneath is brilliant and unchanged. Before the Theban period, no precautions were taken to protect the painter's work from the action of air and light. About the time of the Twentieth Dynasty, however, it became customary to coat painted surfaces with a transparent varnish which was soluble in water, and which was probably made from the gum of some kind of acacia. It was not always used in the same manner. Some painters varnished the whole surface, while others merely glazed the ornaments and accessories, without touching the flesh-tints or the clothing. This medium has cracked from the effects of age, or has become so dark as to spoil the work it was intended to preserve. Doubtless, the Egyptians dis- 
covered the bad effects produced by it, as we no longer meet with it after the close of the Twentieth Dynasty.

Egyptian painters laid on broad, flat, uniform washes of colour, placed in juxtaposition, but never melting one into another. They did not paint in our sense of the term; they illuminated. Just as in drawing they reduced everything to lines, and almost wholly suppressed the internal modelling, so in adding colour they still further simplified their subject by merging all varieties of tone, and all the play of light and shadow, in one uniform tint. Egyptian painting is never quite true, and never quite false. Without pretending to the faithful imitation of nature, it approaches nature as nearly as it may; sometimes understating, sometimes exaggerating, sometimes substituting ideal or conventional renderings for strict realities. Water, for instance, is always represented by a flat tint of blue, or by blue covered with zigzag lines in black. The buff and bluish hues of the vulture are translated into bright red and vivid blue. The flesh-tints of men are always of a dark reddish brown, and the flesh-tints of women are pale yellow. The colours conventionally assigned to every animate and inanimate object were taught in the schools, and the recipe was handed on unchanged from generation to generation. Now and then it happened that a painter more daring than his contemporaries ventured to break with the accustomed tradition. At Sakkarah, under the Fifth Dynasty, and at Aboo-Simbel, under the Nineteenth Dynasty, we find men with skins as yellow as those of the women; while in the tombs of Thebes and Abydos, 
about the time of Thothmes IV. and Horemheb, there occur figures with flesh-tints of rose-colour.* But these novelties lasted at most for a hundred years, and then the schools went back to the old false methods.

It must not, however, be supposed that the effect produced by this artificial system was grating or discordant. Even in works of small size, such as illuminated MSS. of The Book of the Dead, or the decoration of mummy-cases and funerary coffers, there is both sweetness and harmony of colour. The most brilliant hues are boldly placed side by side, yet with full knowledge of the relations subsisting between these hues, and of the phenomena which must necessarily result from such relations. They neither jar together, nor war with each other, nor extinguish each other. On the contrary, each maintains its own value, and both, by mere juxtaposition, give rise to the half-tones which harmonise them.

Turning from small things to large ones, from the page of papyrus, or the panel of sycamore wood, to the walls of tombs and temples, we find the skilful employment of flat tints equally soothing and agreeable to the eye. Each wall is treated as a whole, the harmony of colour being carried out from bottom to top throughout the various superimposed stages into which the surface was divided. Sometimes the colours are distributed according to a scale of rhythm, or symmetry, balancing and counterbalancing each other. Sometimes one special tint predominates,

* The rose-coloured, or rather crimson, flesh-tints are also to be seen in the famous speos at Bayt-el-Wely, tempo Nineteenth Dynasty. [Translator's note.] 
thus determining the general tone and subordinating every other hue. The vividness of the final effect is always calculated according to the quality and quantity of light by which the picture is destined to be seen. In very dark halls the force of colour is carried as far as it will go, because it would not otherwise have been visible by the flickering light of lamps and torches. On outer wall-surfaces and on pylon-fronts, it was as vivid as in the darkest depths of excavated catacombs ; and this because, no matter how extreme it might be, the sun would subdue its splendour. But in half-lighted places, such as the porticoes of temples and the antechambers of tombs, coiour is so dealt with as to be soft and discreet. In a word, painting was in Egypt the mere humble servant of architecture and sculpture. We must not dream of comparing it with our own, or even with that of the Greeks; but if we take it simply for what it is, accepting it in the secondary place assigned to it, we cannot fail to recognise its unusual merits. Egyptian painting excelled in the sense of monumental decoration, and if we ever revert to the fashion of colouring the façades of our houses and our public edifices, we shall lose nothing by studying Egyptian methods or reproducing Egyptian processes.

\section{WORKS OF PAINTING AND SCULPTURE.}

To this day, the most ancient statue known is a colossus-namely, the Great Sphinx of Gizeh. It was already in existence in the time of Khoofoo (Cheops), and perhaps we should not be far wrong if we ventured to ascribe it to the generations before Mena, called 
in the priestly chronicles "the Servants of Horus." Hewn in the living rock at the extreme verge of the

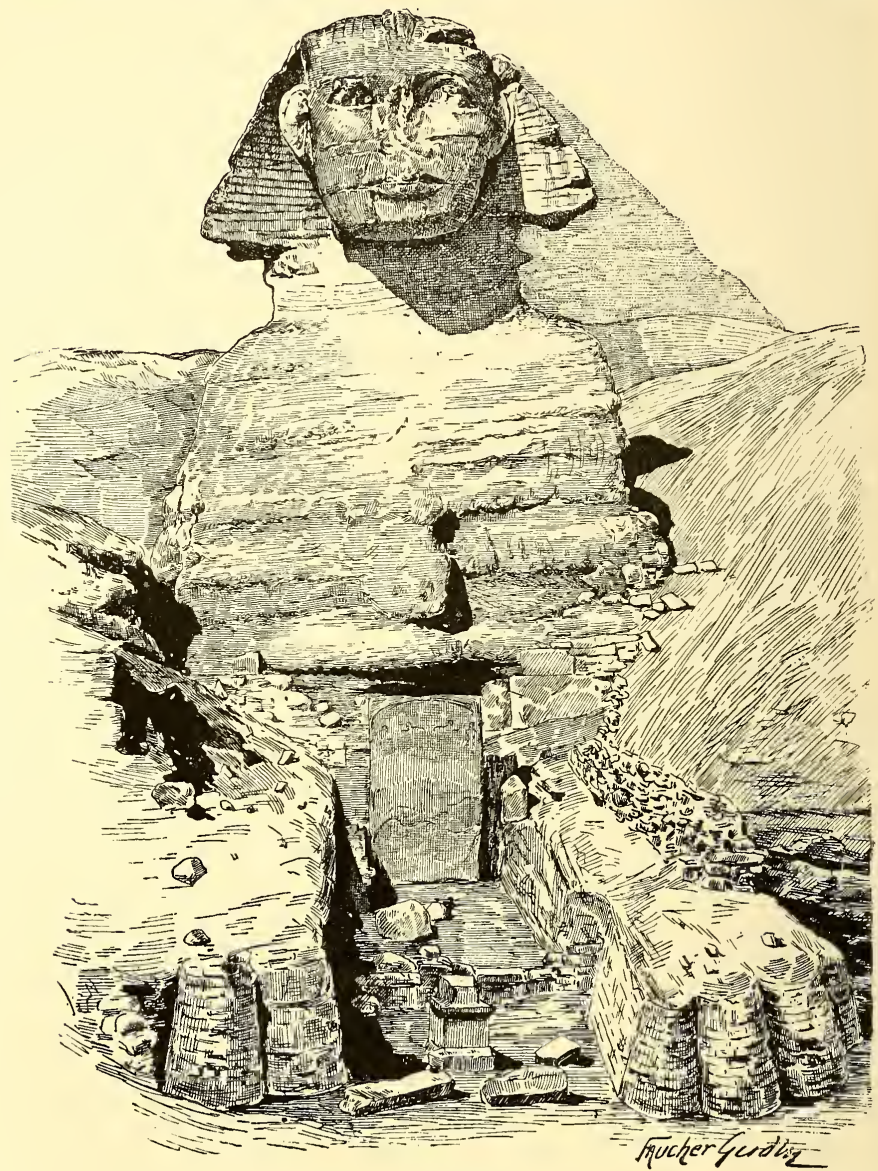

Fig. 179 .

Libyan plateau, it seems, as the representative of Horus, to uprear its head in order to be the first to 
catch sight of his father, $\mathrm{Ra}$, the rising sun, across the valley (fig. I79). For centuries the sands have buried it to the chin, yet without protecting it from ruin. Its battered body preserves but the general form of a lion's body. The paws and breast, restored by the Ptolemies and the Cæsars, retain but a part of the stone facing with which they were then clothed in order to mask the ravages of time. The lower part of the head-dress has fallen, and the diminished neck looks too slender to sustain the enormous weight of the head. The nose and beard have been broken off by fanatics, and the red hue which formerly enlivened the features is almost wholly effaced. And yet, notwithstanding its fallen fortunes, the monster preserves an expression of sovereign strength and greatness. The eyes gaze out afar with a look of intense and profound thoughtfulness; the mouth still wears a smile; the whole countenance is informed with power and repose. The art which conceived and carved this prodigious statue was a finished art; an art which had attained self-mastery, and was sure of its effects. How many centuries had it taken to arrive at this degree of maturity and perfection? In certain pieces belonging to various museums, such as the statues of Sepa and his wife at the Louvre, and the bas-reliefs of the tomb of Khabiousokari at Boulak, critics have mistakenly recognised the faltering first efforts of an unskilled people. The stiffness of attitude and gesture, the exaggerated squareness of the shoulders, the line of green paint daubed under the eyes, -in a word, all those characteristics which are quoted as signs of extreme antiquity, are found in certain monuments of 
the Fifth and Sixth Dynasties. The contemporary sculptors of any given period were not all equally skilful. If some were capable of doing good work, the greater number were mere craftsmen; and we must be careful not to ascribe awkward manipulation, or lack of teaching, to the timidity of archaism. The works of the primitive dynasties yet sleep undiscovered beneath seventy feet of sand at the foot of the Sphinx; those of the historic dynasties are daily exhumed from the depths of the neighbouring tombs. These have not yielded Egyptian art as a whole; but they have familiarised us with one of its schools-the school of Memphis. The Delta, Hermopolis, Abydos, the environs of Thebes and Assouan," do not appear upon the stage earlier than towards the Sixth Dynasty; and even so, we know them through but a small number of sepulchres long since violated and despoiled. The loss is probably not very great. Memphis was the capital; and thither the presence of the Pharaohs must have attracted all the talent of the vassal principalities. Judging from the results of our excavations in the Memphite necropolis alone, it is possible to determine the characteristics of both sculpture and painting in the time of Seneferoo and his successors with as much exactness as if we were already in

* The classic Syene, from all time the southernmost portion of Egypt proper. The Sixth Dynasty is called of "Elephantine," the kings of that line being descended from a family of Elephantine, the island immediately facing Syene, which was the traditional seat of the Dynasty, and on which the temples stood. The cemetery of Elephantine has recently been discovered by General Sir T. Grenfell, K.C.B., in the neighbouring cliffs of the Libyan Desert: see footnote, p. I44. [Translator's note.] 
possession of all the monuments which the valley of the Nile yet holds in reserve for future explorers.

The lesser folk of the art-world excelled in the manipulation of brush and chisel, and that their skill was of a high order is testified by the thousands of tableaux they have left behind them. The relief is low ; the colour sober; the composition learned. Architecture, trees, vegetation, irregularities of ground, are summarily indicated, and are introduced only when necessary to the due interpretation of the scene represented. Men and animals, on the other hand, are rendered with a wealth of detail, a truth of character, and sometimes a force of treatment, to which the later schools of Egyptian art rarely attained. Six wooden panels from the tomb of Hosi in the Boulak Museum represent perhaps the finest known specimens of this branch of art. Mariette ascribed them to the

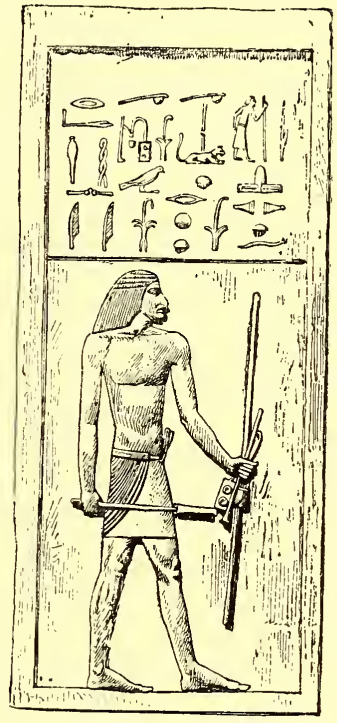

Fig. I8o. Third Dynasty, and he may perhaps have been right; though for my own part I incline to date them from the Fifth Dynasty. In these panels there is nothing that can be called a "subject." Hosi either sits or stands (fig. I 80), and has four or five columns of hieroglyphs above his head; but the firmness of line, the subtlety of modelling, the ease of execution, are 
unequalled. Never has wood been cut with a more delicate chisel or a firmer hand.

The variety of attitude and gesture which we so much admire in the Egyptian bas-relief is lacking to the statues. A mourner weeping, a woman bruising corn for bread, a baker rolling dough, are subjects as rare in the round as they are common in bas-relief. In sculpture, the figure is generally represented either standing with the feet side by side and quite still, or with one leg advanced in the act of walking; or seated upon a chair or a cube; or kneeling; or, still more frequently, sitting on the ground cross-legged, as the Fellaheen are wont to sit to this day. This intentional monotony of style would be inexplicable if we were ignorant of the purpose for which such statues were intended. They represent the dead man for whom the tomb was made, his family, his servants, his slaves, and his kinsfolk. The master is always shown sitting or standing, and he could not consistently be seen in any other attitude. The tomb is, in fact, the house in which he rests after the labours of life, as once he used to rest in his earthly home; and the scenes depicted upon the walls represent the work which he was officially credited with performing. Here he superintends the preliminary operations necessary to raise the food by which he is to be nourished in the form of funerary offerings; namely, seed-sowing, harvesting, stock-breeding, fishing, hunting, and the like. In short, "he superintends all the labour which is done for the eternal dwelling." When thus engaged, he is always standing upright, his head uplifted, his hands pendent, or holding the staff and baton of command. 
Elsewhere, the diverse offerings are brought to him one by one, and then he sits in a chair of state. These are his two attitudes, whether as a bas-relief subject or a statue. Standing, he receives the homage of his vassals ; sitting, he partakes of the family repast. The people of his household comport themselves before him as becomes their business and station. His wife either stands beside him, sits on the same chair or on a second chair by his side, or squats beside his feet as during his lifetime. His son, if a child at the time when the statue was ordered, is represented in the garb of infancy; or with the bearing and equipment proper to his position, if a man. The slaves bruise the corn, the cellarers tar the wine jars, the hired mourners weep and tear their hair. His little social world followed the Egyptian to his tomb, the duties of his attendants being prescribed for them after death, just as they had been prescribed for them during life. And the kind of influence which the religious conception of the soul exercised over the art of the sculptor did not end here. From the moment that the statue is regarded as the support of the Double, it becomes a condition of primary importance that the statue shall reproduce, at least in the abstract, the proportions and distinctive peculiarities of the corporeal body; and this in order that the Double shall more easily adapt himself to his new body of stone or wood.* The head is therefore always a faithful portrait; but the body, on the contrary, is, as it were, a medium kind of body, representing the original at his highest development, and consequently able to

* For an explanation of the nature of the Double, see Chapter III. pp. I08, II 7, and I2I. [Translator's note.] 
exert the fulness of his physical powers when admitted to the society of the gods. Hence men are always sculptured in the prime of life, and women with the delicate proportions of early womanhood. This conventional ideal was never departed ftom, unless in cases of very marked deformity. The statue of a dwarf reproduced all the ugly peculiarities of the dwarf's own body; and it was important that it should so reproduce them. If a statue of the ordinary type had been placed in the tomb of the dead man, his "Ka," accustomed during life to the deformity of his limbs, would not be able to adapt itself to an upright and shapely figure, and would therefore be deprived of the conditions necessary to his future well-being. The artist was free to vary the details and arrange the accessories according to his fancy; but without missing the point of his work, he could not change the attitude, or depart from the general style of the conventional portrait statue. This persistent monotony of pose and subject produces a depressing effect upon the spectator,-an effect which is augmented by the obtrusive character given to the supports. These statues are mostly backed by a sort of rectangular pediment, which is either squared off just at the base of the skull, or carried up in a point and lost in the head-dress, or rounded at the top and showing above the head of the figure. The arms are seldom separated from the body, but are generally in one piece with the sides and hips. The whole length of the leg which is placed in advance of the other is very often connected with the pediment by a band of stone. It has been conjectured that this course was imposed upon the sculptor by reason 
of the imperfection of his tools, and the consequent danger of fracturing the statue when cutting away the superfluous material-an explanation which may be correct as regards the earliest schools, but which does not hold good for the time of the Fourth Dynasty. We could point to more than one piece of sculpture of that period, even in granite, in which all the limbs are free, having been cut away by means of either the chisel or the drill. If pediment supports were persisted in to the end, their use must have been due, not to helplessness, but to routine, or to an exaggerated respect for ancient method.

Most museums are poor in statues of the Memphite school. Among much that is mediocre, France and Egypt possess, however, some twenty specimens which suffice to ensure it an honourable place in the history of art. At the Louvre we have the "Cross-legged Scribe,"* and the statues of Skemka and Pahurnefer ; at Boulak there are the "Sheykh-el-Beled $\dagger$ and his wife, Khafra, $\ddagger$ Ranefer, and the "Kneeling Scribe." The original of the "Cross-legged Scribe" was not a handsome man (fig. I8I), but the vigour and fidelity of his portrait amply compensate for the absence of ideal beauty. His legs are crossed and laid flat to the ground in one of those attitudes common among

* Known as the "Scribe accroupi," literally the "Squatting Scribe"; but in English, squatting, as applied to Egyptian art, is taken to mean the attitude of sitting with the knees nearly touching the chin.

$\dagger$ "The Sheykh of the Village." This statue is best known in England as the "Wooden Man of Boulak."

$\ddagger$ Khafra, sometimes written Shafra: the Greek Chephren. [Translator's note.] 
Orientals, yet all but impossible to Europeans. The bust is upright, and well balanced upon the hips. The head is uplifted. The right hand holds the reed pen, which pauses in its place on the open papyrus scroll.

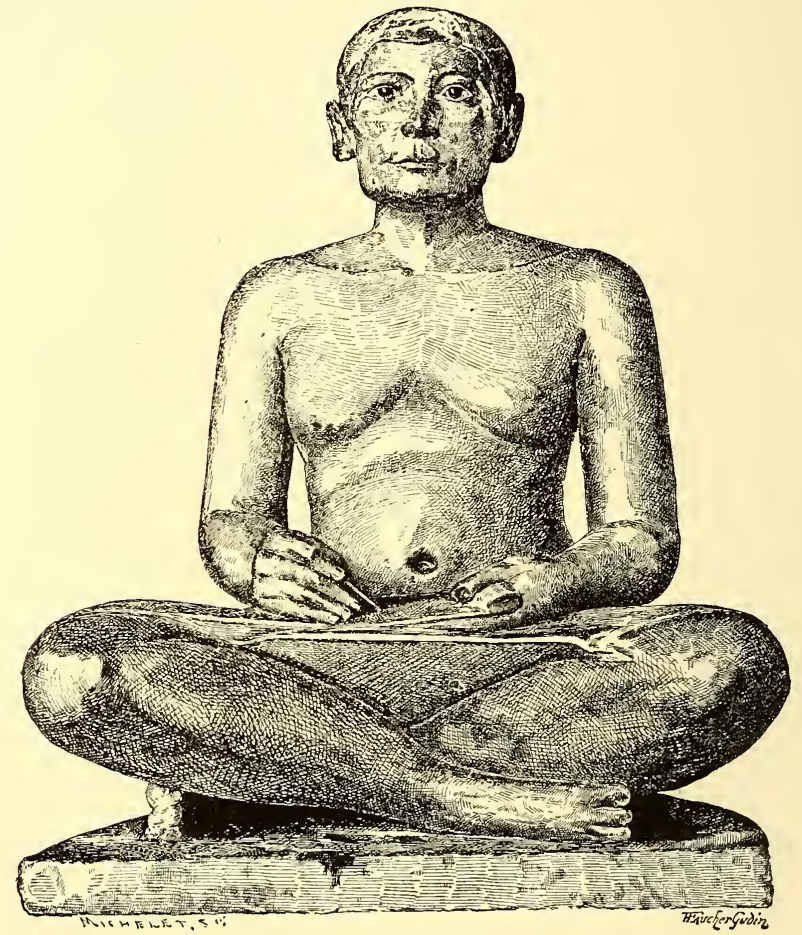

Fig. 181.

Thus, for six thousand years he has waited for his master to go on with the long-interrupted dictation. The face is square-cut, and the strongly-marked features indicate a man in the prime of life. The mouth, wide and thin-lipped, rises slightly towards the corners, 
which are lost in the projecting muscles by which it is framed in. The cheeks are bony and lank; the ears are thick and heavy, and stand out well from the head; the thick, coarse hair is cut close above the brow. The eyes, which are large and well open, owe their lifelike vivacity to an ingenious contrivance of the ancient artist. The orbit has been cut out from the stone, the hollow being filled with an eye composed of enamel, white and black. The edges of the eyelids are of bronze, and a small silver nail inserted behind the iris receives and reflects the light in such wise as to imitate the light of life. The contours of the flesh are somewhat full and wanting in firmness, as would be the case in middle life, if the man's occupation debarred him from active exercise. The forms of the arm and back are in good relief; the hands are hard and bony, with fingers of somewhat unusual length; and the knees are sculptured with a minute attention to anatomical details. The whole body is, as it were, informed by the expression of the face, and is dominated by the attentive suspense which breathes in every feature. The muscles of the arm, of the bust, and of the shoulder are caught in half repose, and are ready to return at once to work. This careful observance of the professional attitude, or the characteristic gesture, is equally marked in all the statues which I have had an opportunity of studying.

Khafra is a king (fig. I82). He sits squarely upon his chair of state, his hands upon his knees, his chest thrown forward, his head erect, his gaze confident. Had the emblems of his rank been destroyed, and the inscription effaced which tells his name, his bearing 
alone would have revealed the Pharaoh. Every trait is characteristic of the man who from childhood upwards has known himself to be invested with sovereign authority. Ranefer belonged to one of the great feudal families of his time. He stands upright, his arms down, his left leg forward, in the attitude of a prince

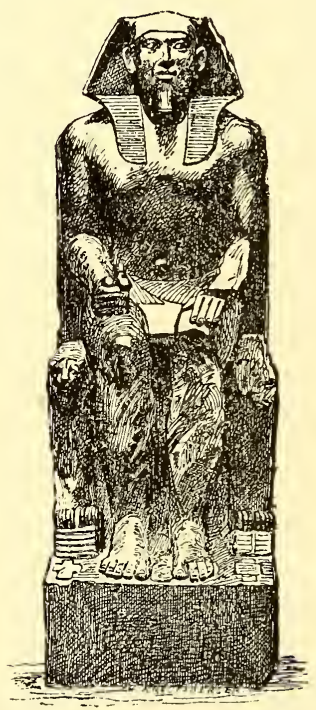

Fig. IS2.

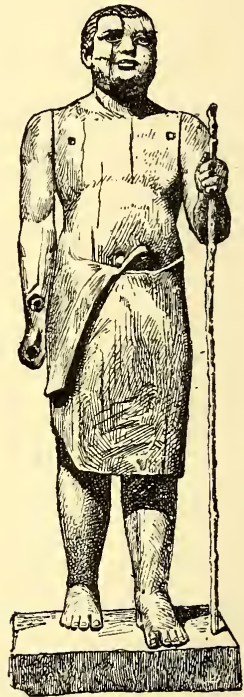

Fig. 183 .

inspecting a march-past of his vassals. The countenance is haughty, the attitude bold; but Ranefer does not impress us with the almost superhuman calm and decision of Khafra. Turning to the "Sheykh-elBeled" (fig. I83), we descend several degrees in the social scale. Ra-em-ka was a "superintendent of works," which probably means that he was an overseer 
of corvée labour at the time of building the great pyramids. He belonged to the middle class; and his whole person expresses vulgar contentment and selfsatisfaction. We seem to see him in the act of watching his workmen, his staff of acacia wood in his hand. The feet of the statue had perished, but have been restored. The body is stout and heavy, and the neck thick. The head (fig. I84), despite its vulgarity, does not lack

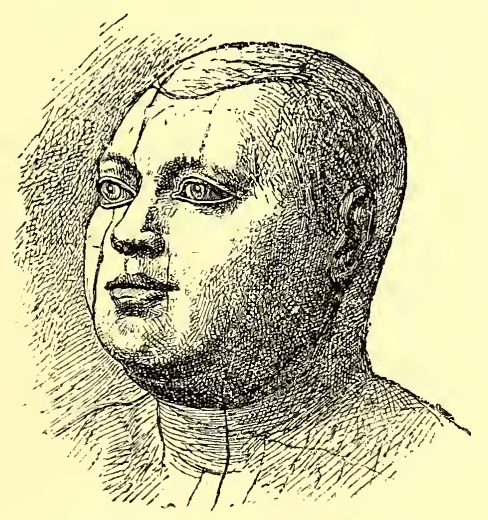

Fig. I84.

energy. The eyes are inserted, like those of the " Cross-legged Scribe." By a curious coincidence, the statue, which was found at Sakkarah, happened to be strikingly like the local Sheykh-el-Beled, or head-man, of the village. Always quick to seize upon the amusing side of an incident, the Arab diggers at once called it the "Sheykh-el-Beled," and it has retained the name ever since. The statue of his wife, interred beside his own, is unfortunately mutilated. It is a mere trunk, 
without legs or arms (fig. I85); yet enough remains to show that the figure represented a good type of

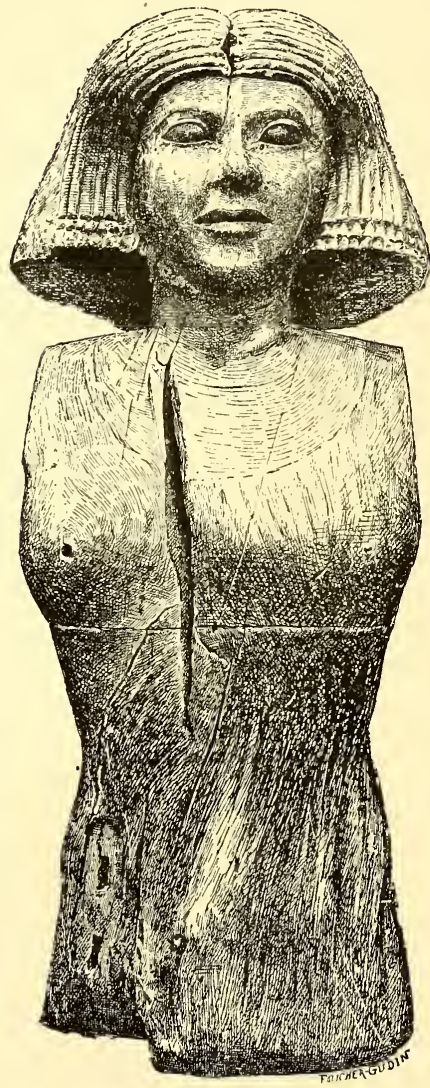

Fig. 185 . the Egyptian middleclass matron, commonplace in appearance and somewhat acid of temper. The "Kneeling Scribe" of the Boulak collection (fig. I 86) belongs to the lowest middle-class rank, such as it is at the present day. Had he not been dead more than six thousand years, I could protest that I met him face to face six months ago, in one of the little towns of Upper Egypt. $\mathrm{He}$ has just brought a roll of papyrus, or a tablet covered with writing, for his master's approval. Kneeling in the prescribed attitude of an inferior, his hands crossed, his shoulders rounded, his head slightly bent forward, he waits till the great man shall have read it through. Of what is he thinking? A scribe might feel some not unreasonable apprehensions, when sum- 
moned thus into the presence of his superior. The stick played a prominent part in official life, and an error of addition, a fault in orthography, or an order misunderstood, would be enough to bring down a shower of blows. The sculptor has, with inimitable skill, seized that expression of resigned uncertainty and passive gentleness which is the result of a whole life of servitude. There is a smile upon his lips, but it is the smile of etiquette, in which there is no gladness. The nose and cheeks are puckered up in harmony with the forced grimace upon the mouth. $\mathrm{His}$ large eyes (again in enamel)

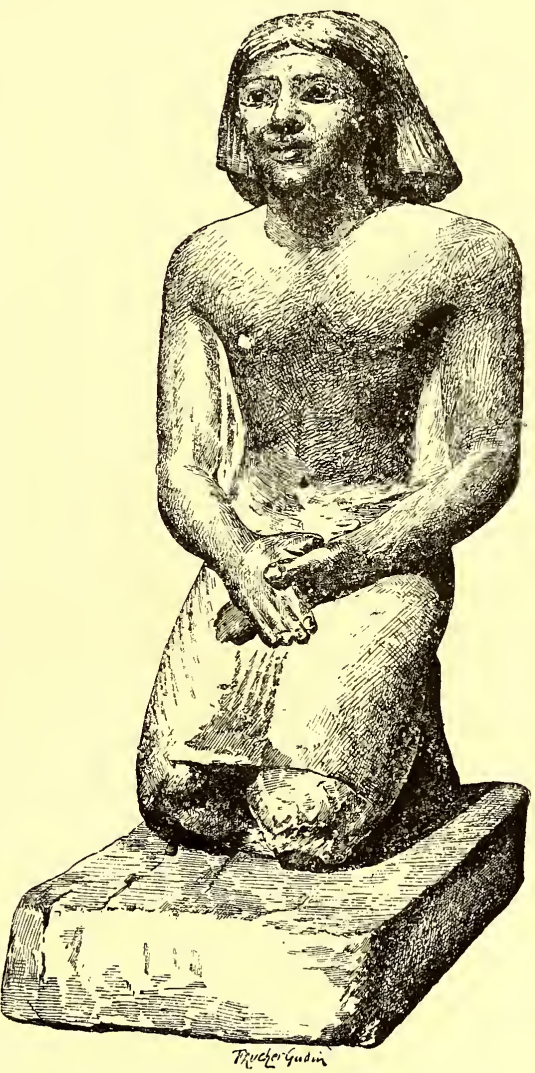

Fig. 186. have the fixed look of one who waits vacantly, without making any effort to concentrate his sight or his thoughts upon a definite object. The face lacks both 
intelligence and vivacity ; but his work, after all, called for no special nimbleness of wit. Khafra is in diorite; Ra-em-ka and his wife are carved in wood; the other statues named are of limestone; yet, whatever the material employed, the play of the chisel is alike free, subtle, and delicate. The head of the scribe and the

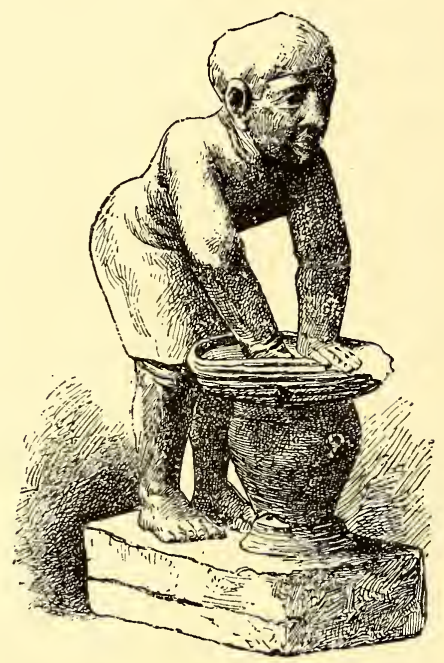

Fig. 187 .

bas-relief portrait of Pharaoh Menkauhor, in the Louvre, the dwarf Khnumhotep, and the slaves who prepare food-offerings at Boulak, are in no wise inferior to the "Cross-legged Scribe" or the "Sheykhel-Beled." The baker kneading his dough (fig. I87) is thoroughly in his work. His half-stooping attitude, and the way in which he leans upon the kneadingtrough, are admirably natural. The dwarf has a 
big, elongated head, balanced by two enormous ears (fig. I88). He has a foolish face, an ill-shapen mouth, and narrow slits of eyes, inclining upwards

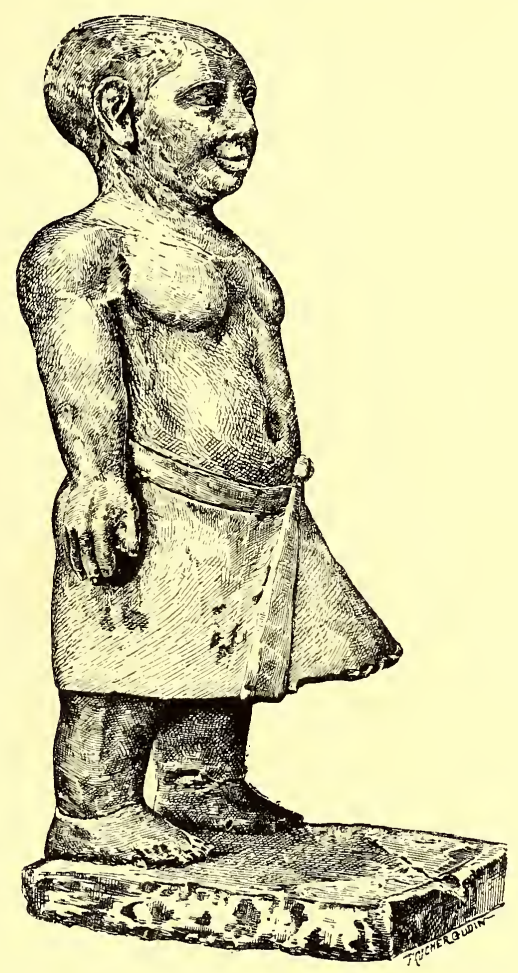

Fig. I 88 .

to the temples. The bust is well developed, but the trunk is out of proportion with the rest of his person. The artist has done his best to disguise the lower limbs under a fine white tunic; but one feels that it is too long for the little man's arms and legs. 
The thighs could have existed only in a rudimentary form, and Khnumhotep, standing as best he can upon his misshapen feet, seems to be off his balance, and ready to fall forward upon his face. It would be difficult to find another work of art in which the characteristics of dwarfdom are more cleverly reproduced.

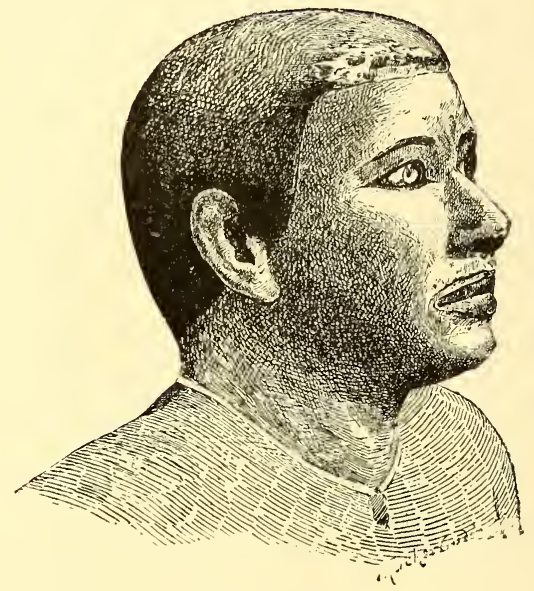

Fig. 189.

The sculpture of the first Theban empire is in close connection with that of Memphis. Methods, materials, design, composition, all are borrowed from the elder school; the only new departure being in the proportions assigned to the human figure. From the time of the Eleventh Dynasty, the legs become longer and slighter, the hips smaller, the body and the neck more slender. Works of this period are not to be compared with the best productions of the earlier centuries. The wall-paintings of Siout, of Bersheh, of Beni-Hassan, 
of Meydoom, of Assouan, are not equal to those in the mastabas of Sakkarah and Gizeh; nor are the most carefully-executed contemporary statues worthy of a place beside the "Sheykh-el-Beled" or the "Crosslegged Scribe." Two, however, are very well done; namely, General Rahotep and his wife, Nefert.*

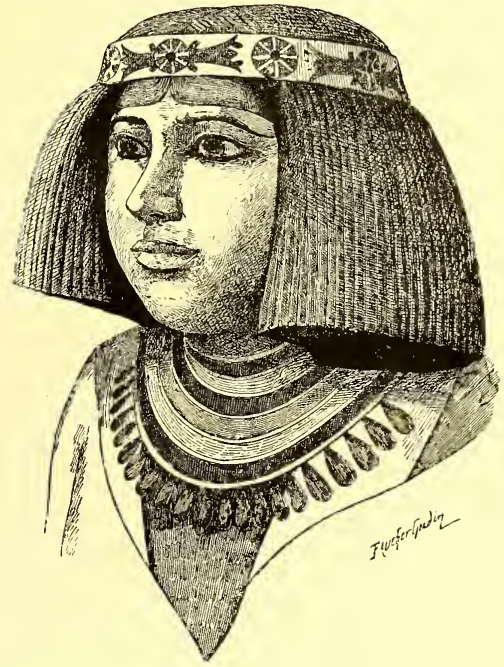

Fig. 190.

Rahotep (fig. I89), despite his high military rank, was of inferior birth. Stalwart and square-cut, he has somewhat of the rustic in his physiognomy. Nefert, on the contrary (fig. I90), was a princess of the blood

* These statues have hitherto been attributed to the Third Dynasty. I venture to think that the heads of Rahotep and Nefert, engraved from a brilliant photograph in A Thousand Miles up the Nile, give a truer and more spirited idea of the originals than the present illustrations. [Translator's note.] 
royal ; and her whole person is, as it were, informed with a certain air of resolution and command, which the sculptor has expressed very happily. She wears a close-fitting garment, opening to a point in front. The shoulders, bosom, and bodily contours are modelled under the drapery with a grace and reserve which it is impossible to praise too highly. Her face, round and plump, is framed in masses of fine black hair, confined by a richly-ornamented bandeau. This wedded pair are in limestone, painted; the husband being coloured of a reddish brown hue, and the wife of a tawny buff. Such other portrait statues of private persons as I have seen, especially those found at Thebes, are decidedly bad, the execution being rude and the expression vulgar. The royal statues of this period, which are nearly all in black or grey granite, have been for the most part usurped by kings of later date. Usertesen III., whose head and feet are in the Louvre, was appropriated by Amenhotep III., as the sphinx of the Louvre and the colossi of Boulak were appropriated by Rameses II. Many museums possess specimens of supposed Ramesside Pharaohs which, upon more careful inspection, we are compelled to ascribe to the Thirteenth or Fourteenth Dynasties. Those of undisputed identity, such as the Sebekhotep III. of the Louvre, the Mermashiu of Tanis, the Sebekemsaf of Boulak, and the colossi of the Isle of Argo, though very skilfully executed, are wanting in originality and vigour. One would say, indeed, that the sculptors had purposely endeavoured to turn them all out after the one smiling and commonplace pattern. Great is the contrast when we turn from these giant 
dolls to the black granite sphinxes discovered by Mariette at Tanis in I86I, and by him ascribed to the Hyksos period. Here energy, at all events, is not lacking. Wiry and compact, the lion body is shorter than in sphinxes of the usual type. The head, instead of wearing the customary "klaft," or head-gear of

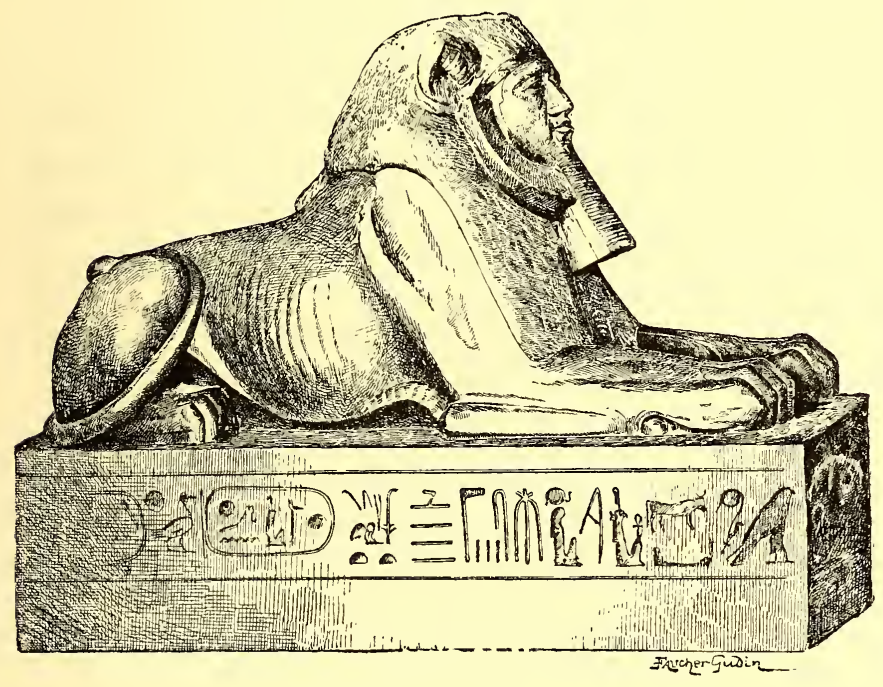

Fig. 19I.

folded linen, is clothed with an ample mane, which also surrounds the face. The eyes are small; the nose is aquiline and depressed at the tip; the cheekbones are prominent; the lower lip slightly protrudes. The general effect of the face is, in short, so unlike the types we are accustomed to find in Egypt, that it has been accepted in proof of an Asiatic origin (fig. I9I). These sphinxes are unquestionably anterior to the 
Eighteenth Dynasty, because one of the kings of Avaris, named Apepi, has cut his name upon the shoulder of each. Arguing from this fact, it has, however, been too hastily concluded that they are works of the time of that prince. On a closer examination, one can see that they had already been dedicated to some Pharaoh of a yet earlier period, and that Apepi had merely usurped them. There is nothing to indicate that this unknown Pharaoh reigned subsequently to the Asiatic invasion. His monuments may, perchance, be the products of a local school, the origin of which may have been independent, and its traditions quite different from the traditions of the Memphite workshops. Except at Abydos, El-Kab, Assouan, and some two or three other places, the provincial art of ancient Egypt is so little known to us, that I dare not lay too much stress upon this hypothesis. Whatever the origin of the Tanite School, it continued to exist long after the expulsion of the Hyksos invaders, since one of its best examples, a group representing the Nile of the North and the Nile of the South, bearing trays laden with flowers and fish, was consecrated by Pisebkhanu of the Twenty-first Dynasty.

The first three dynasties of the New Empire* have bequeathed us more monuments than all the others put together. Painted bas-reliefs, statues of kings and private persons, colossi, sphinxes, may be counted by hundreds between the mouths of the Nile and the fourth cataract. The old sacerdotal cities, Memphis,

* By the New Empire, the Eighteenth, Nineteenth, and Twentieth Dynasties are meant. [Translator's note.] 
Thebes, Abydos, are naturally the richest; but so great was the impetus given to art, that even remote provincial towns, such as Aboo Simbel, Redeseeyeh, and Mesheykh, have their chefs-d'cuvre, like the great cities. The official portraits of Amenhotep I. at Turin, of Thothmes I. and Thothmes III. at the British Museum, at Karnak, at Turin, and at Boulak, are conceived in the style of the Twelfth and Thirteenth Dynasties, and are deficient in originality; but the bas-reliefs in temples and tombs show a marked advance upon those of the earlier ages. The modelling is finer; the figures are more numerous and better grouped; the relief is higher; the effects of perspective are more carefully worked out. The wall-subjects of Dayr-el-Baharee, the tableaux in the tombs of Hui, of Rekhmara, of Anna, of Khamha, and of twenty more at Thebes, are surprisingly rich, brilliant, and varied. Awaking to a sense of the picturesque, artists introduced into their compositions all those details of architecture, of uneven ground, of foreign plants, and the like, which formerly they neglected, or barely indicated. The taste for the colossal, which had fallen somewhat into abeyance since the time of the Great Sphinx, came once again to the surface, and was developed anew. Amenhotep III. was not content with statues of twenty-five or thirty feet in height, such as were in favour among his ancestors. Those which he erected in advance of his memorial chapel on the left bank of the Nile in Western Thebes, one of which is the Vocal Memnon of the classic writers, sit fifty feet high. Each was carved from a single block of granite, and they are as elaborately finished as though they were of ordinary size. The avenues of sphinxes which this Pharaoh 
marshalled before the temples of Luxor and Karnak do not come to an end at fifty or a hundred yards from the gateway, but are prolonged for great distances. In one avenue, they have the human head upon the lion's body ; in another, they are fashioned in the semblance of kneeling rams. Khou-en-Aten, the revolutionary successor of Amenhotep

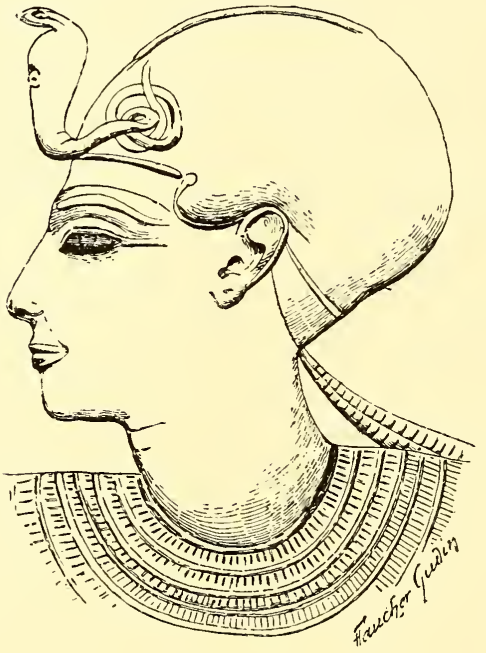

Fig. 192. III., far from discouraging this movement, did what he could to promote it. Never, perhaps, were Egyptian sculptors more unrestricted than by him at Tellel-Amarna. Reviews of military, chariot - driving, popular festivals, state receptions, the distribution of honours and rewards by the king in person, representations of palaces, villas, and gardens, were among the subjects which they were permitted to treat; and these subjects differed in so many respects from traditional routine that they could give free play to their fancy and to their natural genius. The spirit and gusto with which they took advantage of their opportunities would scarcely be believed by one who had not seen their works at Tell-el-Amarna. Some of their bas- 
reliefs are designed in almost correct perspective ; and in all, the life and stir of large crowds are rendered with irreproachable truth. The political and religious reaction which followed this reign arrested the evolution of art, and condemned sculptors and painters to return to the observance of traditional rules. Their personal influence and their teaching continued, however, to make themselves felt under Horemheb, under Seti I., and even under Rameses II. If, during more than a century, Egyptian art remained free, graceful, and refined, that improvement was due to the school of Tell-el-

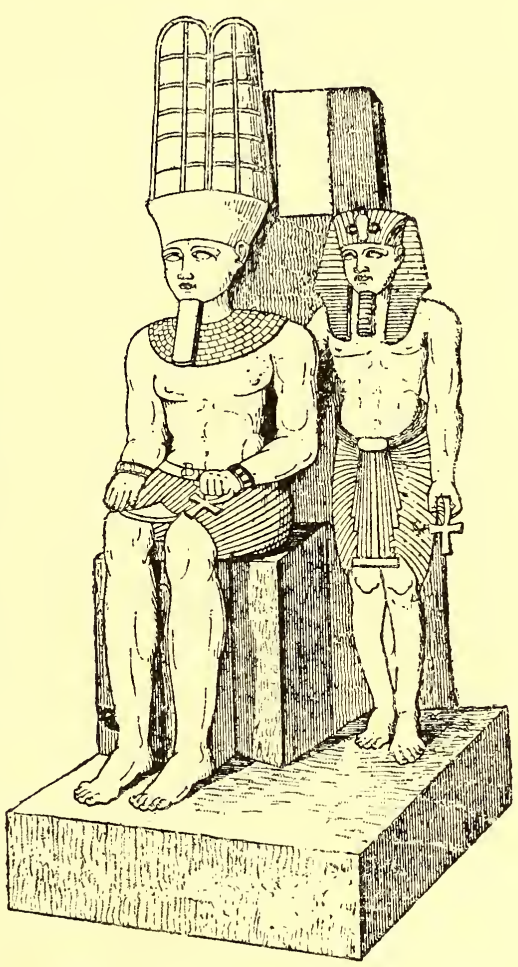

Fig. I93.

Amarna. In no instance perhaps did it produce work more perfect than the bas-reliefs of the Temple of Abydos, or those of the tomb of Seti I. The head of the conqueror (fig. I92), always studied con amore, is a marvel of reserved and sensitive grace. Rameses II. 
charging the enemy at Aboo Simbel is as fine as the portraits of Seti I., though in another style. The action of the arm which brandishes the lance is somewhat angular, but the expression of strength and triumph which animates the whole person of the warrior king, and the despairing resignation of the vanquished, compensate for this one defect. The group of Horemheb and the god Amen (fig. 193), in the Museum of Turin, is a

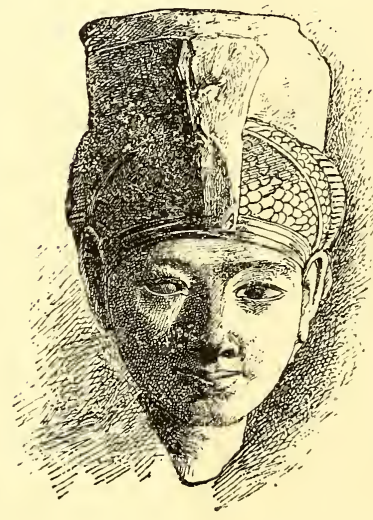

F1g. 194. little dry in treatment. The faces of both god and king lack expression, and their bodies are heavy and illbalanced. The fine colossi in red granite which Horemheb placed against the uprights of the inner door of his first pylon at Karnak, the bas-reliefs on the walls of his speos at Silsilis, his own portrait and that of one of the ladies of his family now in the museum of Boulak, are, so to say, spotless and faultless. The queen's face (fig. 194) is animated and intelligent; the eyes are large and prominent; the mouth is wide, but well shaped. This head is carved in hard limestone of a creamy tint which seems to soften the somewhat satirical expression of her eyes and smile. The king (fig. I95) is in black granite; and the sombre hue of the stone at once produces a mournful impression upon the spectator. His 
youthful face is pervaded by an air of melancholy, such as we rarely see depicted in portraits of Pharaohs of the great period. The nose is straight and delicate, the eyes are long, the lips are large, full, somewhat contracted at the corners, and strongly defined at the edges. The chin is overweighted by the traditional false beard. Every detail is treated with as much skill as if the sculptor were dealing with a soft stone instead of with a material which resisted the chisel. Such, indeed, is the mastery of the execution, that one forgets the difficulties of the

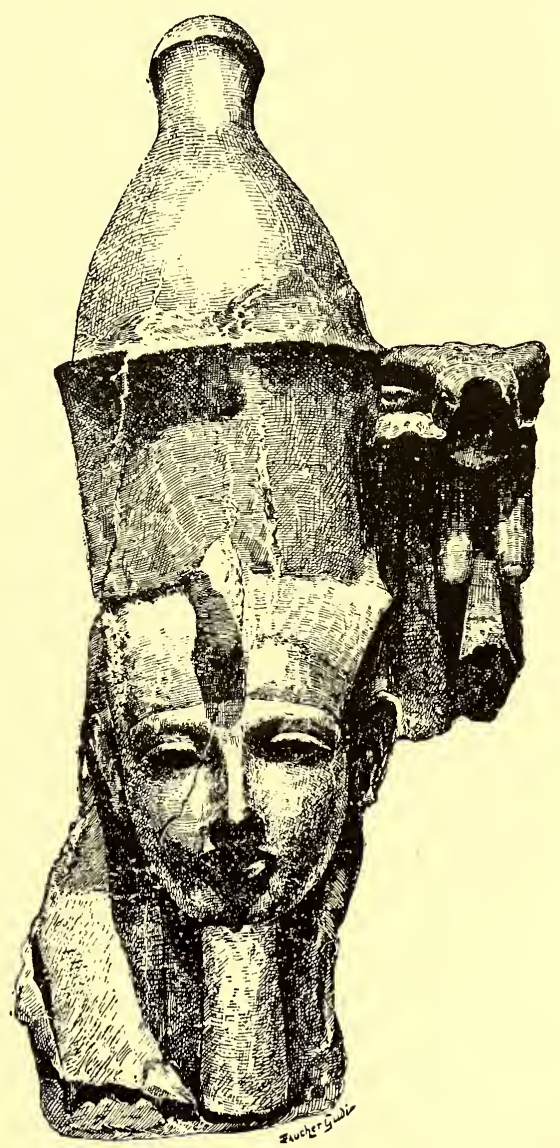

Fig. 195. task in the excellence of the results. It is unfortunate that Egyptian artists never signed their works; for the 
sculptor of this portrait of Horemheb deserves to be remembered. Like the Eighteenth Dynasty, the Nineteenth Dynasty delighted in colossi. Those of Rameses II. at Luxor measured from eighteen to twenty feet in height (fig. I96); the colossal Rameses of the Ramesseum sat sixty feet high; and that of Tanis

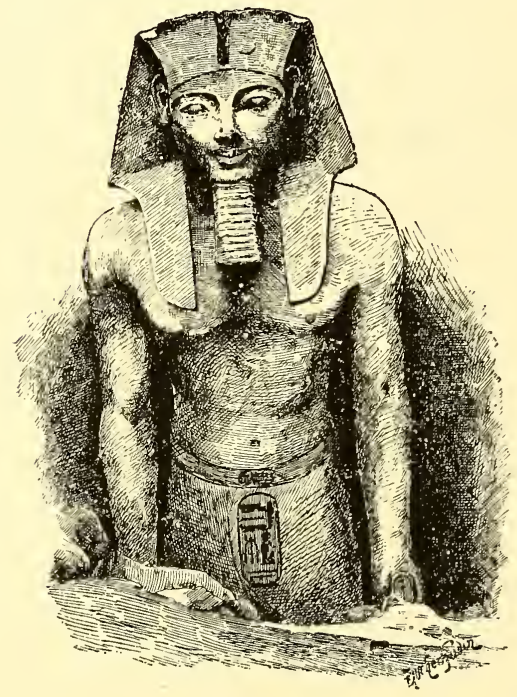

Fig. 196. about seventy.* The colossi of Aboo Simbel, without being of quite such formidable proportions, face the river in imposing array. To say that the decline of Egyptian art began with Rameses II. is a commonplace of contemporary criticism; yet nothing is less true than an axiom of this kind. Many statues and bas-reliefs executed

during his reign are no doubt insupposably rude and ugly; but these are chiefly found in provincial towns where the schools were indifferent, and where the

* According to the measurements given by Mr. Petrie, the discoverer of the Tanite colossus (a standing figure), it must have stood ninety feet high without, and one hundred and twenty feet high with, its pedestal. See Tanis, Part I., by W. M. F. Petrie, published by the Egypt Exploration Fund, I885. [Translator's note.] 
artists had no fine examples before them. At Thebes, at Memphis, at Abydos, at Tanis, in those towns of the Delta where the court habitually resided, and even at Aboo Simbel and Bayt-el-Waly, the sculptors of Rameses II. yield nothing in point of excellence to those of Seti I. and Horemheb. The decadence did not begin till after the reign of Menepthah. When civil war and foreign invasion brought Egypt to the brink of destruction, the arts, like all else, suffered and rapidly declined. It is sad to follow their downward progress under the later Ramessides, whether in the wall-subjects of the royal tombs, or in the bas-reliefs of the temple of Khonsu, or on the columns of the hypostyle hall at Karnak. Wood carving maintained its level during a somewhat longer period. The admirable statuettes of priests and children at Turin date from the Twentieth Dynasty. The advent of Shashank and the internecine strife of the provinces at length completed the ruin of 'Thebes, and the

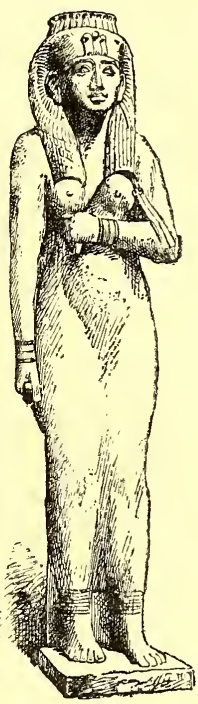

Fig. 197 . school which had produced so many masterpieces perished miserably.

The Renaissance did not dawn till near the end of the Ethiopian Dynasty, some three hundred years later. The over-praised statue of Queen Ameniritis* (fig.

* Ameniritis, daughter of an Ethiopian king named Kashta, was the sister and successor of her brother Shabaka, and wife of Piankhi II., XXVth Dynasty. The statue is in alabaster. [Translator's note.] 
I97) already manifests some noteworthy qualities. The limbs, somewhat long and fragile, are delicately treated; but the head is heavy, being over-weighted by the wig peculiar to goddesses. Psammetichus I., when his victories had established him upon the throne, busied himself in the restoration of the temples.

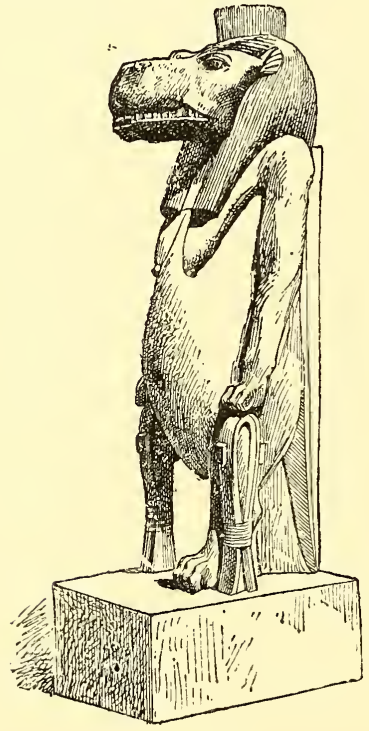

Fig. 198.

Under his auspices, the vailey of the Nile became one vast studio of painting and sculpture. The art of engraving hieroglyphs attained a high degree of excelience, fine statues and bas-reliefs were everywhere multiplied, and a new school arose. A marvellous command of material, a profound knowledge of detail, and a certain elegance tempered by severity, are the leading characteristics of this new school. The Memphites preferred limestone; the 'Thebans selected red or grey granite; but the Saïtes especially attacked basalt, breccia, and serpentine, and with these fine-grained and almost homogeneous substances, they achieved extraordinary results. They seem to have sought difficulties for the mere pleasure of triumphing over them; and we have proof of the way in which artists of real merit bestowed years and years on 
the chasing of sarcophagus lids and the carving of statues in blocks of the hardest material. The Thoueris, and the four monuments from the tomb of Psammetichus * in the Boulak Museum, are the most remarkable objects hitherto discovered in this class of work. Thoueris $†$ (fig. 198) was the especial protectress of maternity, and presided over childbirth. Her portrait was discovered by some native Sebakh diggers $\ddagger$ in the midst of the mounds of the ancient city of Thebes. She was found standing upright in a little chapel of white limestone which had been dedicated to her by one Pibesa, a priest, in the name of Queen Nitocris, daughter of Psammetichus I. This charming hippopotamus, whose figure is perhaps more plump than graceful, is a fine example of difficulties overcome; but I do not know that she has any other merit. The group belonging to Psammetichus has at all events some artistic value. It consists of four pieces of green basalt ; namely, a table of offerings, a statue of Osiris, a statue of Nephthys, and a Hathor-cow supporting a statuette of the deceased (fig. 199). All four are somewhat flaccid, somewhat artificial; but the faces of

* A Memphite scribe of the Thirtieth Dynasty. [Translator's note.]

† In Egyptian Ta-urt, or "the Great;" also called Apet. This goddess is always represented as a hippopotamus walking. She carries in each hand the emblem of protection, called "Sa." The statuette of the illustration is in green serpentine. [Translator's note.]

† Sebakh, signifying "salt," or "saltpetre," is the general term for that saline dust which accumulates wherever there are mounds of brick or limestone ruins. This dust is much valued as a manure, or "top-dressing," and is so constantly dug out and carried away by the natives, that the mounds of ancient towns and villages are rapidly undergoing destruction in all parts of Egypt. [Translator's note.] 
the divinities and the deceased are not wanting in sweetness; the action of the cow is good; and the little figure under her protection falls naturally into its place. Certain other pieces, less known than these, are however far superior. The Saïtic style is easy of recognition. It lacks the breadth and learning of the first Memphite school; it also lacks the grand, and

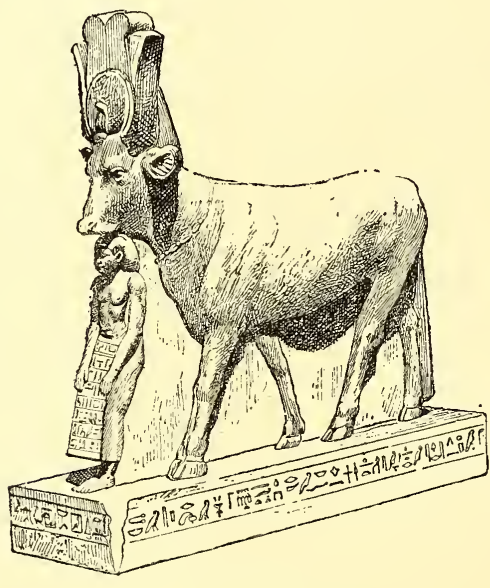

Fig. 199. sometimes rude, manner of the great Theban school. The proportions of the human body are reduced and elongated, and the limbs lose in vigour what they gain in elegance. A noteworthy change in the choice of attitudes will also be remarked. Orientals find repose in postures which would be inexpressibly fatiguing to ourselves. For hours together they will kneel ; or sit tailor-wise, with the legs crossed and laid down flat to the ground; or squat, sitting upon their heels, with no other support than is afforded by that part of the sole of the foot which rests upon the ground; or they will sit upon the floor with their legs close together, and their arms crossed upon their knees. These four attitudes were customary among the people from the time of the ancient empire. 
This we know from the bas-reliefs. But the Memphite sculptors, deeming the two last ungraceful, excluded them from the domain of art, and rarely, if ever, reproduced them. The "Cross-legged Scribe" of the Louvre and the "Kneeling Scribe" of Boulak show with what success they could employ the two first. The third was neglected (doubtless for the same reason) by the Theban sculptors. The fourth began to be currently adopted about the time of the Eighteenth Dynasty.

It may be that this position was not in fashion among the moneyed classes, which alone could afford to order statues; or it may be that the artists themselves

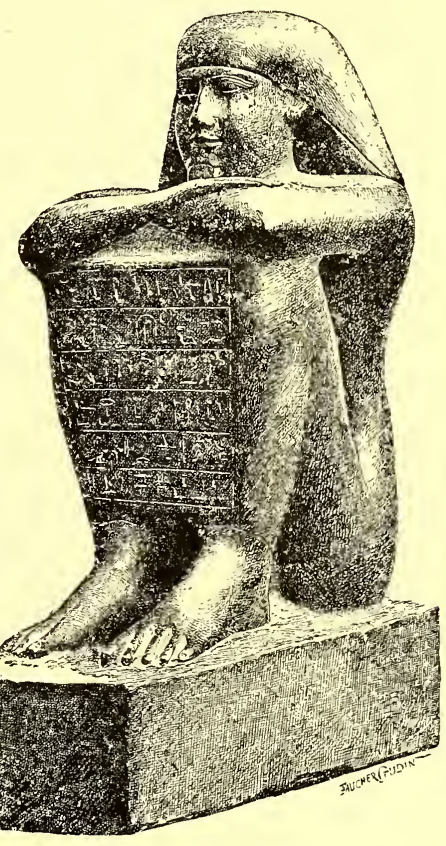

Fig. 200. objected to an attitude which caused their sitters to look like square parcels with a human head on the top. The sculptors of the Saite period did not inherit that repugnance. They have at all events combined the action of the limbs in such wise as may least offend the eye, and the position almost ceases 
to be ungraceful. The heads also are modelled to such perfection that they make up for many shortcomings. That of Pedishashi (fig. 200) has an expression of youth and intelligent gentleness such we seldom meet with from an Egyptian hand. Other heads, on the contrary, are remarkable for their almost brutal frankness of treatment. In the small head of a scribe (fig. 2OI), lately purchased for the Louvre, and in another

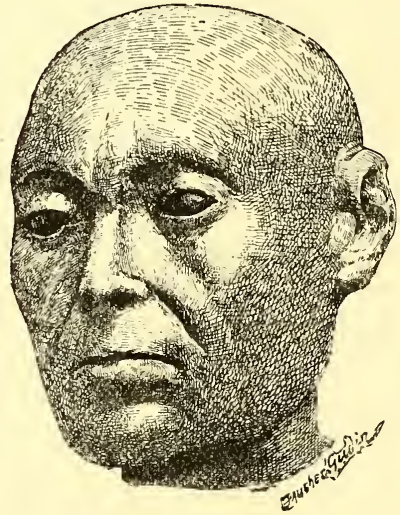

Fig.'201. belonging to Prince Ibrahim at Cairo, the wrinkled brow, the crow's-feet at the corners of the eyes, the hard lines about the mouth, and the knobs upon the skull, are brought out with scrupulous fidelity. The Saïte school was, in fact, divided into two parties. One sought inspiration in the past, and, by a return to the methods of the old Memphite school, endeavoured to put fresh life into the effeminate style of the day. This it accomplished, and so successfully, that its works are sometimes mistaken for the best productions of the Fourth and Fifth Dynasties. The other, without too openly departing from established tradition, preferred to study from the life, and thus drew nearer to nature than in any previous age. This school would, perhaps, have prevailed, had Egyptian art not been directed into a new channel by the Macedonian conquest, and by centuries of intercourse with the Greeks. 
The new departure was of slow development. Sculptors began by clothing the successors of Alexander in Egyptian garb and transforming them into Pharaohs, just as they had in olden time transformed the Hyksos and the Persians. Works dating from the reigns of the first Ptolemies scarcely differ from those of the best Saite period, and it is only here and there that we detect traces of Greek influence. Thus, the colossus of Alexander II., at Boulak (fig. 202), wears a flowing head-dress, from beneath which his crisp curls have found their way. Soon, however, the sight of Greek masterpieces led the Egyptians of Alexandria, of Memphis, and of the cities of the Delta to modify their artistic methods. Then arose a mixed school, which combined certain elements of the national art with certain other elements borrowed from Hellenic art. The Alexandrian Isis of the Boulak Museum is clad as the Isis of Pharaonic times; but she has lost the old slender shape and

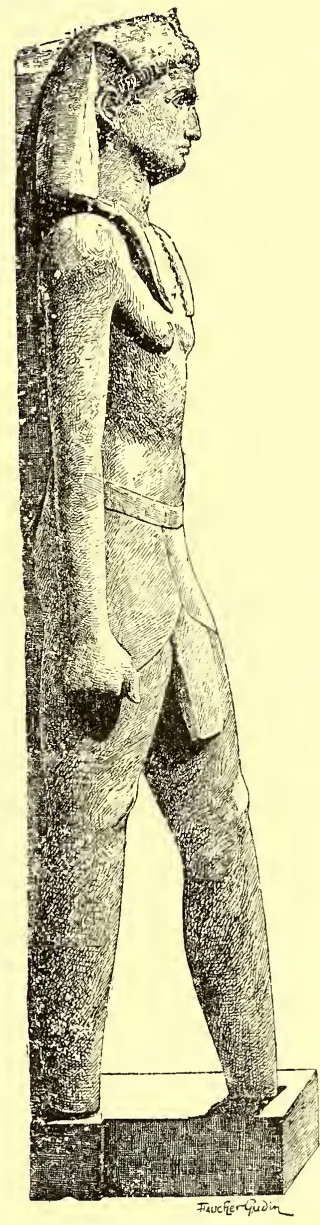

Fig. 202. straitened bearing. A mutilated effigy of a Prince of 
Siout, also at Boulak, would almost pass for an indifferent Greek statue.

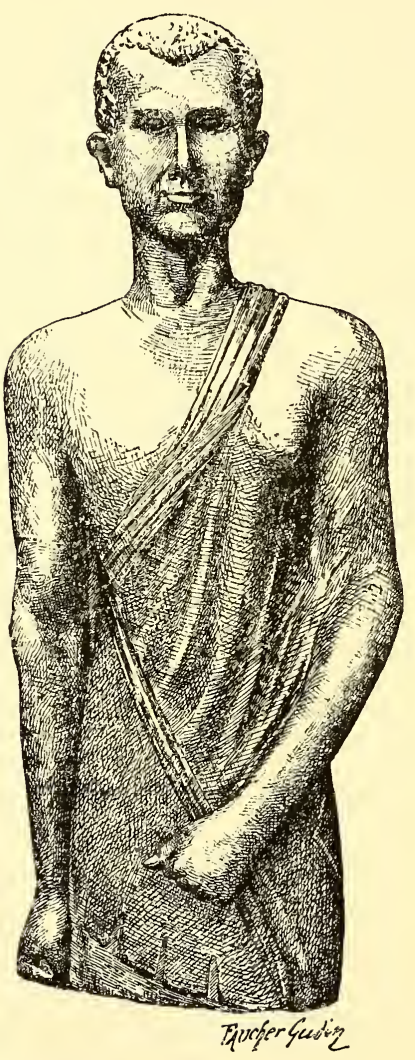

Fig. 203 .

'The most forcible work of this hybrid class which has come down to us is the portrait-statue of one Hor (fig. 203), discovered in $\mathrm{I} 88 \mathrm{I}$ at the foot of Kom-ed-Damas, the site of the tomb of Alexander. The head is good, though in a somewhat dry style. The long, pinched nose, the close-set eyes, the small mouth with drawn-in corners, the square chin, - every feature, in short, contributes to give a hard and obstinate character to the face. The hair is closely cropped, yet not so closely as to prevent it from dividing naturally into thick, short curls. The body, clothed in the chlamys, is awkwardly shapen, and too narrow for the head. One arm hangs pendent; the other is brought round to the front; the feet are lost. All these monuments are the results of recent excavations; and I do not 
doubt that the soil of Alexandria would yield many such, if it could be methodically explored. The school which produced them continued to draw nearer and nearer to the schools of Greece, and the stiff manner, which it never wholly lost, was scarcely regarded as a defect at an epoch when certain sculptors in the service of Rome especially affected the archaic style. I should not be surprised if those statues of priests and priestesses wearing divine insignia, with which Hadrian adorned the Egyptian rooms of his villa at Tibur, might not be attributed to the artists of this hybrid school. In those parts which were remote from the Delta, native art, being left to its own resources, languished, and slowly perished. Nor was this because Greek models, or even Greek artists, were lacking. In the Thebaid, in the Fayoom, at Syene, I have both discovered and purchased statuettes and statues of Hellenic style, and of correct and careful execution. One of these, from Coptos, is apparently a miniature replica of a Venus analogous to the Venus of Milo. But the provincial sculptors were too dull, or too ignorant, to take such advantage of these models as was taken by their Alexandrian brethren. When they sought to render the Greek suppleness of figure and fulness of limb, they only succeeded in missing the rigid but learned precision of their former masters. In place of the fine, delicate, low relief of the old school, they adopted a relief which, though very prominent, was soft, round, and feebly modelled. The eyes of their personages have a foolish leer; the nostrils slant upwards; the corners of the mouth, the chin, and indeed all the features, are drawn up 
as if converging towards a central point, which is stationed in the middle of the ear. Two schools, each independent of the other, have bequeathed their works to us. The least known flourished in Ethiopia, at the court of the half-civilised kings who resided at Meroë. A group brought from Naga in I882, and now in the Boulak collection, shows the

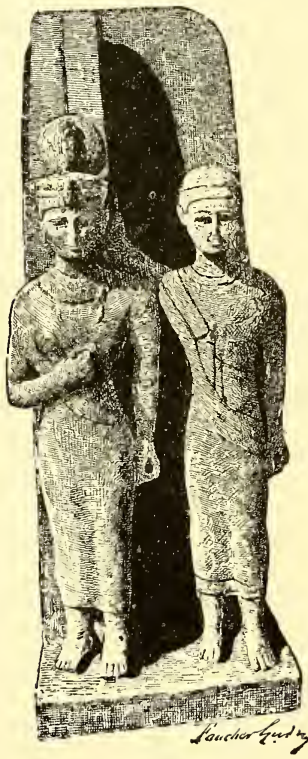

Fig. 204. work of this school during the first century of our era (fig. 204). A god and a queen, standing side by side, are roughly cut in a block of grey granite. The work is coarse and heavy, but not without energy. Isolated and lost in the midst of savage tribes, the school which produced it sank rapidly into barbarism, and expired towards the end of the age of the Antonines. The Egyptian school, sheltered by the power of Rome, survived a little longer. As sagacious as the Ptolemies, the Cæsars knew that by flattering the religious prejudices of their Egyptian subjects they consolidated their own rule in the valley of the Nile. At an enormous cost, they restored and rebuilt the temples of the national gods, working after the old plans and in the old spirit of Pharaonic times. The great earthquake of B.c. 22 had destroyed Thebes, which now became a mere place of pilgrimage, whither devotees repaired to listen to the voice of 
Memnon at the rising of Aurora. But at Denderah and Ombos, Tiberius and Claudius finished the decoration of the great temples. Caligula worked at Coptos, and the Antonines enriched Esneh and Philæ. The gangs of workmen employed in their names were still competent to cut thousands of bas-reliefs according to the rules of the olden time. Their work was feeble, ungraceful, absurd, inspired solely by routine; yet it was founded on antique tradition-tradition enfeebled and degenerate, but still alive. The troubles which convulsed the third century of our era, the incursions of barbarians, the progress and triumph of Christianity, caused the suspension of the latest works and the dispersion of the last craftsmen. With them died all that yet survived of the national art. 


\section{CHAPTER V.}

THE INDU.STRIAL ARTS.

I HAVE treated briefly of the Noble Arts; it remains to say something of the Industrial Arts. All classes of society in Egypt were, from an early period, imbued with the love of luxury, and with a taste for the beautiful. Living or dead, the Egyptian desired to have jewels and costly amulets upon his person, and to be surrounded by choice furniture and elegant utensils. The objects of his daily use must be distinguished, if not by richness of material, at least by grace of form ; and in order to satisfy his requirements, the clay, the stone, the metals, the woods, and other products of distant lands were laid under contribution.

\section{STONE, CLAY, AND GLASS.}

It is impossible to pass through a gallery of Egyptian antiquities without being surprised by the prodigious number of small objects in pietra dura which have survived till the present time. As yet we have found neither the diamond, the ruby, nor the sapphire; but with these exceptions, the domain of the lapidary was almost as extensive as at the present day. That domain included the amethyst, the emerald, the garnet, the aquamarine, the chrysoprase, the innumerable varieties 
of agate and jasper, lapis lazuli, feidspath, obsidian ; also various rocks, such as granite, serpentine, and porphyry; certain fossils, as yellow amber and some kinds of turquoise; organic remains, as coral, mother-of-pearl, and pearls; metallic oxides, such as hematite, the Oriental turquoise, and malachite. These substances were for the most part cut in the shape of round, square, oval, spindle-shaped, pear-shaped, or lozengeshaped beads. Strung and arranged row

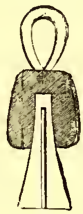

Fig. 205. above row, these beads were made into necklaces, and are picked up by myriads in the sands of the great cemeteries at Memphis, Erment, Ekhmeem, and Abydos.

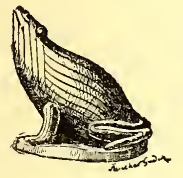

Fig. 206. The perfection with which many are cut, the deftness with which they are pierced, and the beauty of the polish, do honour to the craftsmen who made them. But their skill did not end here. With no tool save the point, they fashioned these materials into an infinity of shapes-hearts, human fingers, serpents, animals, images of divinities. All these were amulets; and they were probably less valued for the charm of the workmanship than for the supernatural virtues which they were supposed to possess. The girdle-buckle in carnelian (fig. 205) was the blood of Isis, and it washed away the sins of the wearer. The frog (fig. 206) was emblematic of renewed birth. The little lotus-flower column in Fig. 207. green feldspath (fig. 207) symbolised the divine gift of eternal youth. The "Uta," or symbolic eye (fig. 208), tied to the wrist or the arm by a slender 
string, protected one against the evil eye, against words spoken in envy or anger, and against the bites of serpents. Commerce dispersed these objects throughout all parts of the ancient world, and many of them, especially those which represented the sacred beetle, were imitated abroad by the Phœnicians and Syrians, and by the craftsmen of Greece, Asia Minor, Etruria,

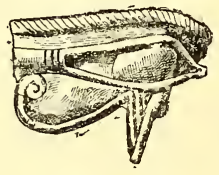

Fig. 208. and Sardinia. This insect was called kheper in Egyptian, and its name was supposed to be derived from the root khepra, "to become." By an obvious play upon words, the beetle was made the emblem of terrestrial life, and of the successive "becomings" or developments of man in the life to come. The scarabæus amulet (fig. 209) is therefore a symbol of duration, present or future; and to wear one was to be provided with a safeguard against death. A thousand mystic meanings were evolved from this first idea, each in some subtle sense connected with one or other of the daily acts or usages of life, so that scarabæi were multiplied ad infinitum. They are found in all materials and sizes; some with hawks' heads, some with

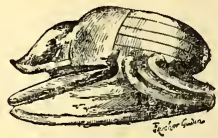

Fig. 209. rams' heads, some with heads of men or bulls. Some are as elaborately wrought on the underside as on the upper; others are flat and plain underneath; and others again but vaguely recall the form of the insect, and are called scarabæoids. These amulets are pierced longwise, the hole being large enough to admit the passage of a fine wire of bronze or silver, 
or of a thread for suspension. The larger sort were regarded as images of the heart. These, having outspread wings attached, were fastened to the breast of the mummy, and are inscribed on the underside with a prayer adjuring the heart not to bear witness against the deceased at the day of judgment. In order to be still more efficacious, some scenes of adoration were occasionally added to the formula; i.e., the disc of the moon adored by two apes upon the shoulder; two squatting figures of Amen upon the wing-sheaths; on the flat reverse, a representation of the boat of the Sun; and below the boat, Osiris mummified, squatting between Isis and Nephthys, who overshadow him with their wings. The small scarabs, having begun as phylacteries, ended by becoming mere ornaments without any kind of religious meaning, like the crosses worn as an addition to their toilet by the women of our own day. They were set as rings, as necklace pendants, as earrings, and as bracelets. The underside is often plain, but is more commonly ornamented with incised designs which involve no kind of modelling. Relief-cutting, properly so called (as in cameo-cutting), was unknown to Egyptian lapidaries before the Greek period. The subjects engraved on scarabæi have not yet been classified, nor even completely catalogued.* They consist of simple combinations of lines; of scrolls; of interlacings without any

* The only works on scarabæi yet published are the Palin collection, published in 1828, and Mr. Loftie's charming Essay of Scarabs, which is in fact a catalogue of his own specimens, admirably illustrated from drawings by Mr. W. M. F. Petrie. Mr. Petrie has, however, a much more elaborate and comprehensive work on scarabæi in preparation. [Translator's note.] 
precise signification; of symbols to which the owner attached a mysterious meaning, unknown to everyone but himself; of the names and titles of individuals; of royal ovals, which are historically interesting; of good wishes; of pious ejaculations ; and of magic formulæ. Several scarabæi of obsidian and crystal date from the Sixth Dynasty. Others, coarse and uninscribed, are of amethyst, emerald, and even garnet; these belong to the dawn of the Theban empire. From the time of the Eighteenth Dynasty they count by millions, and the execution is more or less fine according to the hardness of the stone. This, in fact, holds good for amulets of all kinds. The hippopotamus-heads, the hearts, the souls with human faces, which one picks up at Taoud, to the southward of Thebes, are barely roughed out, the amethyst and green feldspath of which they are made having presented an almost unconquerable resistance to the point. The belt-buckles, angles, and head-rests in red jasper, carnelian, and hematite, are, on the contrary, finished to the minutest details, these stones being such as can be attacked without difficulty by a mediocre instrument. Lapis lazuli is soft, insufficiently homogeneous, liable to crumble when cut to an edge, and seems as if it were incapable of being finely worked. Yet the Egyptians have used it for images of certain goddesses-Isis, Nephthys, Neith, Sekhet,-which are marvels of delicate cutting. The modelling of the forms is carried out as boldly as if the material were more trustworthy, and the features lose none of their excellence if examined under a magnifying glass. For the most part, however, a different treatment was adopted. 
Instead of lavishing high finish upon the relief, it was obtained in a more summary way, the details of individual parts being sacrificed to the general effect. Those features of the face which project, and those which retire, are strongly accentuated. The thickness of the neck, the swell of the breast and shoulder, the slenderness of the waist, the fulness of the hips are all exaggerated. The feet and hands are also slightly enlarged. This treatment is based upon a system, the results being boldly and yet judiciously calculated. When the object has to be sculptured in miniature, a mathematical reduction of the model is not so happy in its effect as might be supposed. The head loses character; the neck looks too weak; the bust is reduced to a cylinder with a slightly uneven surface; the feet do not look strong enough to support the weight of the body; the principal lines are not sufficiently distinct from the secondary lines. By suppressing most of the accessory forms and developing those most essential to the expression, the Egyptians steered clear of the danger of producing insignificant statuettes. The eye instinctively tones down whatever is too forcible, and supplies what is lacking. Thanks to these subtle devices of the ancient craftsman, a tiny statuette of this or that divinity measuring scarcely an inch and a quarter in height, has almost the breadth and dignity of a colossus.

The earthly goods of the gods and of the dead were mostly in solid stone. I have elsewhere described the little funerary obelisks, the altar bases, the statues, and the tables of offerings found in tombs of the ancient empire. These tables were made of alabaster and 
limestone during the Pyramid period, of granite or red sandstone under the Theban kings, and of basalt or serpentine from the time of the Twenty-sixth Dynasty. But the fashions were not canonical, all stones being found at all periods. Some offering-tables are mere flat discs, or discs very slightly hollowed. Others are rectangular, and are sculptured in relief with a service of loaves, vases, fruits, and quarters of beef and gazelle. In one instance-the offering-table of Sitou - the libations, instead of running off, fell into a square basin which is marked off in divisions, showing the height of the Nile at the different seasons of the year in the reservoirs of Memphis; namely, twenty-five cubits in summer during the inundation, twenty-three in autumn and early winter, and twenty-two at the close of winter and in spring-time. In these various patterns there was little beauty; yet one offering-table, found at Sakkarah, is a real work of art. It is of alabaster. Two lions, standing side by side, support a sloping, rectangular tablet, whence the libation ran off by a small channel into a vase placed between the tails of the lions. The alabaster geese found at Lisht are not without artistic merit. They are cut lengthwise down the middle, and hollowed out, in the fashion of a box. Those which I have seen elsewhere, and, generally speaking, all simulacra of offerings, as loaves, cakes, heads of oxen or gazelles, branches of black grapes, and the like, in carved and painted limestone, are of doubtful taste and clumsy execution. They are not very common, and I have met with them only in tombs of the Fifth and Twelfth Dynasties. Canopic vases, on the contrary, were always carefully wrought. They 
were made in but two kinds of stone-limestone and alabaster; but the heads which surmounted them were often of painted wood. The canopic vases of Pepi I. are of alabaster; and those of a king buried in the southernmost pyramid at Lisht are also of alabaster, as are the human heads upon the lids. One, indeed, is of such fine execution that I can only compare it with that of the statue of Khafra. The most ancient

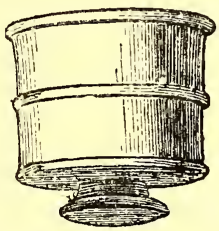

Fig. 2 I0. funerary statuettes yet found-those, namely, of the Eleventh Dynasty-are of alabaster, like the canopic vases; but from the time of the Thirteenth Dynasty, they were cut in compact limestone. The workmanship is very unequal in quality. Some are real chefs-d'cuvre, and reproduce the physiognomy of the deceased as faithfully as a portrait statue. Lastly, there are the perfume vases, which complete the list of objects Fig. 2II. found in temples and tombs. The names of these vases are far from being satisfactorily established, and most of the special designations furnished in the texts remain as yet without equivalents in our language. The greater number were of alabaster, turned and polished. Some are heavy and ugly (fig. 210), while others are distinguished by an elegance and diversity of form which do honour to the inventive talent of the craftsmen. Many are spindle-

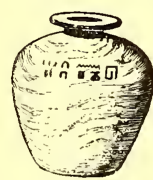

g. 2 I 2 . shaped and pointed at the end (fig. 2 I I), or round in the body, narrow in the neck, and flat at the bottom (fig. 212). They are unornamented, except perhaps by 
two lotus-bud handles, or two lions' heads, or perhaps a little female head just at the rise of the neck (fig. 2I3). The smallest of these vases were not intended for liquids, but for pomades, medicinal ointments, and salves made with honey. Some of the more important series comprise large-bodied flasks, with an upright cylin-

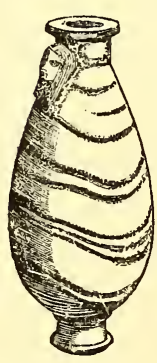

Fig. 213 . drical neck and a flat cover (fig. 214). In these, the Egyptians kept the antimony powder with which they darkened their eyes and eyebrows. The Kohl-pot was a universal toilette ornament; perhaps the only one commonly used by all classes of society. When designing it, the craftsman gave free play to his fancy, borrowing forms of men, plants, and animals for its adornment. Now it appears in the guise of a full-blown lotus; now it is a hedgehog; a hawk; a monkey clasping a column to his breast, or climbing up the side of a jar; a grotesque figure of the god Bes; a kneeling woman, whose scooped-out body contained the powder; a young girl carrying a wine-jar. Once started upon this path, the imagination of the artists knew no limits. As for materials, everything was made to serve in turn-granite, diorite, breccia, red jade, alabaster, and soft

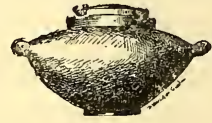

Fig. 214. limestone, which lent itself more readily to caprices of form; finally, a still more malleable and facile substance-clay, painted and glazed.

It was not for want of material that the art of modelling and baking clays failed to be as fully developed in Egypt as in Greece. The valley of the 
Nile is rich in a fine and ductile potter's clay, with which the happiest results might have been achieved, had the native craftsman taken the trouble to prepare it with due care. Metals and hard stone were, however, always preferred for objects of luxury; the potter was fain, therefore, to be content with supplying only the commonest needs of household and daily life. He was wont to take whatever clay happened to be nearest to the place where he was working, and this clay was habitually badly washed, badly kneaded, and fashioned with the finger upon a primitive wheel worked by the hand. The firing was equally careless. Some pieces were barely heated at all, and melted if they came into contact with water, while others were as hard as tiles. All tombs of the ancient empire contain vases of a red or yellow ware, often mixed, like the clay of bricks, with finely-chopped straw or weeds. These are mostly large solid jars with oval bodies, short necks, and wide mouths, but having neither foot nor handles. With them are also found pipkins and pots, in which to store the dead man's provisions; bowls more or less shallow; and flat plates, such as are still used by the fellaheen. The poorer folk sometimes buried miniature table and kitchen services with their dead, as being less costly than full-sized vessels. The surface is seldom glazed, seldom smooth and lustrous; but is ordinarily covered with a coat of whitish, unbaked paint, which scales off at a touch. Upon this surface there is neither incised design, nor ornament in relief, nor any kind of inscription, but merely some four or five parallel lines in red, black, or yellow, round the neck. 
The pottery of the earliest Theban dynasties which I have collected at El-Khozam and Gebelayn is more carefully wrought than the pottery of the Memphite period. It may be classified under two heads. The first comprises plain, smooth-bodied vases, black below and dark red above. On examining this ware where broken, we see that the eolour was mixed with the clay during the kneading, and that the two zones were separately prepared, roughly joined, and then uniformly glazed. The second class comprises vases of various and sometimes eccentric forms, moulded of red or tawny clay. Some are large cylinders closed at one

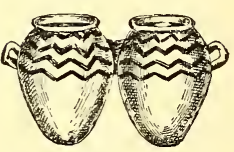

Fig. 215 . end; others are flat; others oblong and boat-shaped; others, like cruets, joined together two and two, yet with no channel of communication* (fig. 215). The ornamentation is carried over the whole surface, and generally consists of straight parallel lines, cross lines, zigzags, dotted lines, or small crosses and lines in geometrical combination; all these patterns being in white when the ground is red, or in reddish brown when the ground is yellow or whitish. Now and then we find figures of men and animals interspersed among the geometrical combinations. The drawing is rude, almost childish; and it is difficult to tell whether the subjects represent herds of antelopes or scenes of gazelle-hunting. The craftsmen who produced these rude attempts were nevertheless contemporary with the artists who decorated the rock-cut tombs at Beni-

* These twin vases are still made at Assouan. I bought a small specimen there in 1874 . [Translator's note.] 
Hassan. As regards the period of Egypt's great military conquests, the Theban tombs of that age have supplied objects enough to stock a museum of pottery; but unfortunately the types are very uninteresting. To begin with, we find hand-made sepulchral statuettes modelled in summary fashion from an oblong lump of clay. A pinch of the craftsman's fingers brought out the nose; two tiny knobs and two little stumps, separately modelled and stuck on, represented the eyes and arms. The better sort of figures were pressed in moulds of baked clay, of which several specimens have been found. They were generally moulded in one piece; then lightly touched up; then baked; and lastly, on coming out of the oven, were painted red, yellow, or white, and inscribed with the pen. Some are of very good style, and almost equal those made in limestone. The Ushabti of the scribe Hori, in the Boulak collection, are about twelve inches high, and show what the Egyptians could have achieved in this branch of the art if they had cared to cultivate it. Funerary cones were objects purely devotional, and the most consummate art could have done nothing to make them elegant. A funerary cone consists of a long, conical mass of clay, stamped at the larger end with a few rows of hieroglyphs stating the name, parentage, and titles of the deceased, the whole surface being coated with a whitish wash. These are simulacra of votive cakes, intended for the eternal nourishment of the Double. Many of the vases buried in tombs of this period are painted to imitate alabaster, granite, basalt, bronze, and even gold ; and were cheap substitutes for those vases made in precious materials 
which wealthy mourners were wont to lavish on their dead. Among those especially intended to contain water or flowers, some are covered with designs drawn in red and black (fig. 216), such as concen-

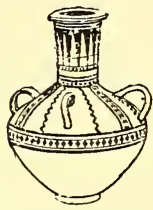

Fig. 216. tric lines and circles (fig. 2 I 7), meanders, religious emblems (fig. 218), cross-lines resembling network, festoons of flowers and buds, and long leafy stems carried downward from the neck to the body of the vase, and upward from the body of the vase to the neck. Those in the tomb of Sennotmou were decorated on one side with a large necklace, or collar, like the collars found upon mummies, painted in very bright colours to simulate natural flowers or enamels. Canopic vases in baked clay, though rarely met with under the Eighteenth Dynasty, became more and Fig. 217. more common as the prosperity of Thebes declined. The heads upon the lids are for the most part

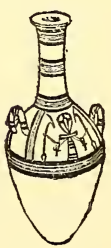
prettily turned, especially the human heads.* Modelled with the hand, scooped out to diminish the weight, and then slowly baked, each was finally painted with the colours especially pertaining to the genius whose head was represented. Towards the time of Fig. 2I8. the Twentieth Dynasty, it became customary to enclose the bodies of sacred animals in vases of this

* The funerary vases commonly called "canopic" were four in number, and contained the embalmed viscera of the mummy. The lids of these vases were fashioned to represent the heads of the four genii of Amenti, Hapi, Tuatmutf, Kebhsennef, and Amset; i.e., the Ape-head, the Jackal-head, the Hawk-head, and the human head. [Translator's note.] 
type. Those found near Ekhmeem contain jackals and hawks; those of Sakkarah are devoted to serpents, eggs, and mummified rats ; those of Abydos hold the sacred ibis. These last are by far the finest. On the body of the vase, the protecting goddess Khouit is depicted with outspread wings, while Horus and Thoth are seen presenting the bandage and the unguent vase ; the whole subject being painted in blue and red upon a white ground. From the time of the Greek domination, the national poverty being always on the increase, baked clay came into use for coffins as well as for canopic vases. In the Isthmus of Suez, at Ahnas-elMedineh, in the Fayoom, at Assouan, and in Nubia, we find whole cemeteries in which the sarcophagi are made of baked clay. Some are like oblong boxes rounded at each end, with a saddle-back lid. Some are in human form, but barbarous in style, the heads being surmounted by a pudding-shaped imitation of the ancient Egyptian head-dress, and the features indicated by two or three strokes of the modelling tool or the thumb. Two little lumps of clay stuck awkwardly upon the breast indicate the coffin of a woman. Even in these last days of Egyptian civilisation, it was only the coarsest objects which were left of the natural hue of the baked clay. As of old, the surfaces were, as a rule, overlaid with a coat of colour, or with a richly gilded glaze.

Glass was known to the Egyptians from the remotest period, and glass-blowing is represented in tombs which date from some thousands of years before our era (fig. 219). The craftsman, seated before the furnace, takes up a small quantity of the fused substance upon 
the end of his cane and blows it circumspectly, taking care to keep it in contact with the flame, so that it may not harden during the operation. Chemical analysis shows the constituent parts of Egyptian glass to have been nearly identical with our own; but it contains, besides silex, calx, alumina, and soda, a relatively large proportion of extraneous substances, as copper, oxide of iron, and oxide of manganese, which they apparently knew not how to eliminate. Hence Egyptian glass is scarcely ever colourless, but inclines to an uncertain shade of yellow or green. Some ill-made pieces are so utterly decomposed that they flake away, or fall to iridescent dust, at the lightest touch. Others have suffered little

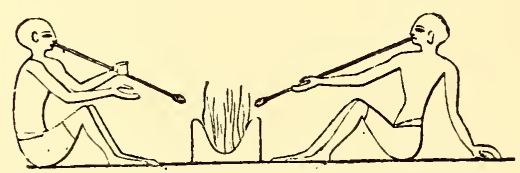

Fig. 219. from time or damp, but are streaky and full of bubbles. A few are, however, perfectly homogeneous and limpid. Colourless glass was not esteemed by the Egyptians as it is by ourselves; whether opaque or transparent, they preferred it coloured. The dyes were obtained by mixing metallic oxides with the ordinary ingredients; that is to say, copper and cobalt for the blues, copperas for the greens, manganese for the violets and browns, iron for the yellows, and lead or tin for the whites. One variety of red contains 30 per cent. of bronze, and becomes coated with verdigris if exposed to damp. All this chemistry was empirical, and acquired by instinct. Finding the necessary elements at hand, or being supplied with them from a distance, they made use of them at hazard, and without being too certain of 
obtaining the effects they sought. Many of their most harmonious combinations were due to accident, and they could not reproduce them at will. The masses which they obtained by these unscientific means were nevertheless of very considerable dimensions. The classic authors tell of stelæ, sarcophagi, and columns made in one piece. Ordinarily, however, glass was used only for small objects, and, above all, for counterfeiting precious stones. However cheaply they may have been sold in the Egyptian market, these small objects were not accessible to all the world. The glass-workers imitated the emerald, jasper, lapis lazuli, and carnelian to such perfection that even now we are sometimes embarrassed to distinguish the real stones from the false. The glass was run into moulds made of stone or limestone cut to the forms required, as beads, discs, rings, pendants, rods, and plaques covered with figures of men and animals, gods and goddesses. Eyes and eyebrows for the faces of statues in stone or bronze were likewise made of glass, as also bracelets. Glass was inserted into the hollows of incised hieroglyphs, and hieroglyphs were also cut out in glass. In this manner, whole inscriptions were composed, and let into wood, stone, or metal. The two mummy-cases which enclosed the body of Netem-t, mother of the Pharaoh Herhor Se-Amen, are decorated in this style. Except the headdress of the effigy and some minor details, these cases are gilded all over; the texts and the principal part of the ornamentation being formed of glass enamels, which stand out in brilliant contrast with the dead gold ground. The Fayoom mummies were coated with plaster or stucco, the texts and 
religious designs, which are generally painted, being formed of glass enamels incrusted upon the surface of the plaster. Some of the largest are made of several pieces of glass joined together and retouched with the chisel, in imitation of bas-relief. Thus the face, hands, and feet of the goddess Ma are done in turquoise blue, her headdress in dark blue, her feather in alternate stripes of blue and yellow, and her raiment in deep red. Upon a wooden shrine recently discovered in the neighbourhood of Daphnæ,* and upon a fragment of mummy-case in the Museum of Turin, the hieroglyphic forms of many-coloured glass are inlaid upon the sombre ground of the wood, the general effect being inconceivably rich and brilliant. Glass filigrees, engraved glass, cut glass, soldered glass, glass imitations of wood, of straw, and of string, were all known to the Egyptians of old. I have under my hand at this present moment a square rod formed of innumerable threads of coloured glass fused into one solid body, which gives the royal oval of one of the Amenemhats at the part where it is cut through. The design is carried through the whole length of the rod, and wherever that rod may be cut, the royal oval reappears. $\dagger$ One glass case in the Boulak Museum is entirely stocked with small objects

* The remains of this shrine, together with many hundreds of beautiful glass hieroglyphs, figures, emblems, etc., for inlaying, besides moulds and other items of the glassworker's stock, were discovered by Mr. F. Ll. Griffith at Tell Gemayemi, about equidistant from the mounds of Tanis and Daphnæ (Sān and Defenneh) in March 1886. For a fuller account see Mr. Griffith's report, printed in the Report of the Fourth Annual General Meeting of the Egypt Exploration Fund, 1885-6. [Translator's note.]

$\dagger$ Some of these beautiful rods were also found at Tell Gemayemi by Mr. F. Ll. Griffith, and in such sound condition that it was possible to cut them in thin slices, for distribution among various museums. [Translatcr's note.] 
in coloured glass. Here we see an ape on all fours, smelling some large fruit which lies upon the ground; yonder, a woman's head, front face, upon a white or green ground surrounded by a red border. Most of the plaques represent only rosettes, stars, and single flowers or posies. One of the smallest represents a black-and-white Apis, walking, the work being so delicate that it loses none of its effect under the magnifying glass. The greater number of these objects date from, and after, the first Saïte dynasty ; but our Theban excavations prove that the taste for coloured glass (and consequently its fabrication) was common

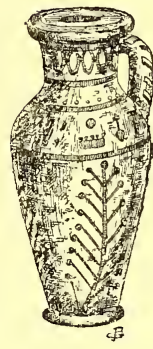

Fig. 220. in Egypt from the tenth century before our era. At Koornet-Murraee and Sheykh Abd-el-Goornah, there have been found, not only amulets for the use of the dead, such as colonnettes, hearts,

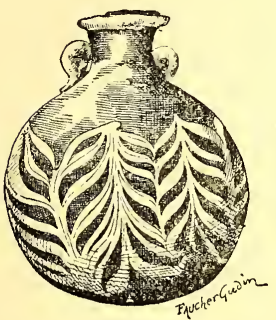

Fig. 221. mystic eyes, hippopotami walking erect, and ducks in pairs, done in parti-coloured pastes, blue, red, and yellow, but also vases of a type which we have been accustomed to regard as of Phøenician and Cypriote manufacture.* Here, for example, is a little œnochoe, of a light blue semi-opaque glass (fig. 220); the inscription in the name of Thothmes III., the ovals on the neck, and the palm-fronds on the body of the vase being in yellow. Here again is a len-

* That is, of the kind known as the "false murrhine." [Translator's note.] 
ticular phial, three and a quarter inches in height (fig. 22I), the ground colour of a deep ocean blue, admirably pure and intense, upon which a fern-leaf pattern in yellow stands out both boldly and delicately. A yellow thread runs round

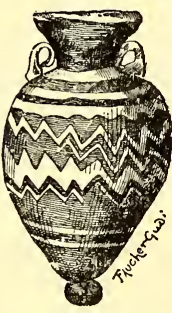

Fig. 222. the rim, and two little handles of light green are attached to the neck. A miniature amphora of the same height (fig. 222) is of a dark, semi-transparent olive green. A zone of blue and yellow zigzags, bounded above and below by yellow bands, encircles the body of the vase at the part of its largest circumference. 'The handles are pale green, and the thread round the lip is pale blue. Princess Nesikhonsu had beside her, in the vault at Dayr-el-Baharee, some glass goblets of similar work. Seven were in

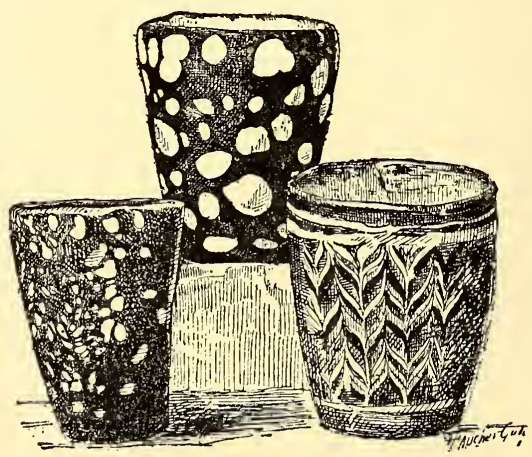

Fig. 223 .

whole colours, light green and blue; four were of black glass spotted with white; one only was decorated with many-coloured fern-leaves arranged in two 
rows (fig. 223). The national glass works were therefore in full operation during the time of the great Theban dynasties. Huge piles of scoriæ mixed with slag yet mark the spot where their furnaces were stationed at the Ramesseum, at El-Kab, and at the Tell of Eshmooneyn.

The Egyptians also enamelled stone. One half at least of the scarabæi, cylinders, and amulets contained in our museums are of limestone, schist, or lignite, covered with a coloured glaze. Doubtless the common clay seemed to them inappropriate to this kind of decoration, for they substituted in its place various sorts of earth-some white and sandy; another sort brown and fine, which they obtained by the pulverisation of a particular kind of limestone found in the neighbourhood of Keneh, Luxor, and Assouan ; and a third sort, reddish in tone, and mixed with powdered sandstone and brick-dust. These various substances are known by the equally inexact names of Egyptian porcelain and Egyptian faïence. The oldest specimens, which are hardly glazed at all, are coated with an excessively thin slip. This vitreous matter has, however, generally settled into the hollows of the hieroglyphs or figures, where its lustre stands out in strong contrast with the dead surface of the surrounding parts. The colour most frequently in use under the ancient dynasties was green; but yellow, red, brown, violet, and blue were not disdained. Blue predominated in the Theban factories from the earliest beginning of the Middle Empire. This blue was brilliant, yet tender, in imitation of turquoise or lapis lazuli. The Boulak Museum formerly contained three hippopota- 
muses of this shade, discovered in the tomb of an Entef at Drah-Aboo'l-Neggah.* One was lying down; the two others were standing in the marshes, their bodies being covered by the potter with pen-and-ink sketches of reeds and lotus plants, amid which hover birds and butterflies. This was his naïve way of depicting the animal amid his natural surroundings. The blue is splendid, and we must overleap twenty centuries before we again find so pure a colour among the funerary statuettes of Dayr-el-Baharee. Green reappears under the Saïte dynasties, but it is a paler

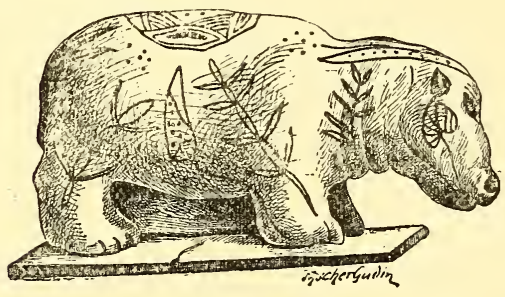

Fig. 224 . green than that of more ancient times. This hue prevailed in the north of Egypt, at Memphis, Bubastis, and Sais, without, however, entirely banishing the blue. The other colours before mentioned were in current use for not more than four or five centuries ; that is to say, from the time of Ahmes I. to the time of the Ramessides. It was then, and only then, that "Ushabti" of white or red glaze, rosettes and lotus flowers in yellow, red, and violet, and parti-coloured kohl-pots abounded. The potters of the time of Amenhotep III. had a special liking for greys and violets. The olive-shaped amulets which are inscribed with the names of this Pharaoh and the princesses of his family are decorated with

* There is a fine specimen at the Louvre, and another in the museum at Leyden. [Translator's note.] 
pale blue hieroglyphs upon a delicate mauve ground. The vase of Queen Tii in the Boulak collection is of grey and blue, with ornaments in two colours round the neck. The fabrication of many-coloured enamels seems to have attained its greatest development under Khoo-en-Aten; at all events, it was at Tell-el-Amarnathat I found the brightest and most delicately fashioned specimens, such as yellow, green, and violet rings, blue and white fleurettes, fish, lutes, figs, and bunches of grapes. One little statuette of Horus has a red face and

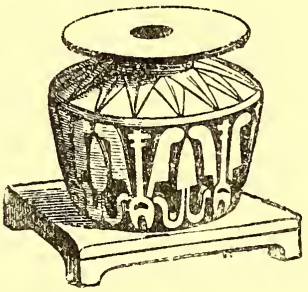

Fig. 225 . a blue body; a ring bezel bears the name of a king in violet upon a ground of light blue. However restricted the space, the various colours are laid in with so sure a hand that they never run one into the other, but stand out separately and vividly. A

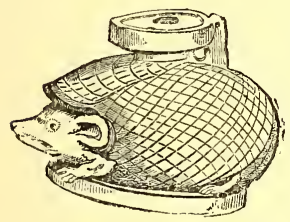

Fig. 226. vase to contain antimony powder, chased and mounted on a pierced stand, is glazed with reddish brown (fig. 225). Another, in the shape of a mitred hawk, is blue picked out with black spots. It belonged of old to Ahmes I. A third, hollowed out of the body of an energetic little hedgehog, is of a changeable green (fig. 226). A Pharaoh's head in dead blue wears a klaft* with

* Klaft, i.e., a headdress of folded linen. The beautiful little head here referred to is in the Boulak Museum, and is a portrait of the Pharaoh Necho. [Translator's note.] 
dark-blue stripes. Fine as these pieces are, the chefd'cuvre of the series is a statuette of one Ptahmes, first Prophet of Amen, now in the Boulak

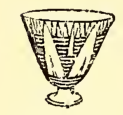

Fig. 227 . Museum. The hieroglyphic inscriptions as well as the details of the mummy bandages are chased in relief upon a white ground of admirable purity, and filled in with enamel. The face and hands are of turquoise blue; the head-dress is yellow, with violet stripes; the hieroglyphic characters of the inscription, and the vulture with outspread wings upon the breast of the figure, are also violet. The whole is delicate, brilliant, and harmonious; not a flaw mars

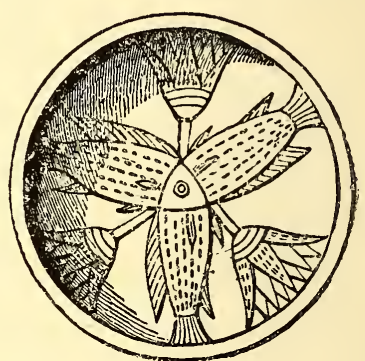

Fig. 228.

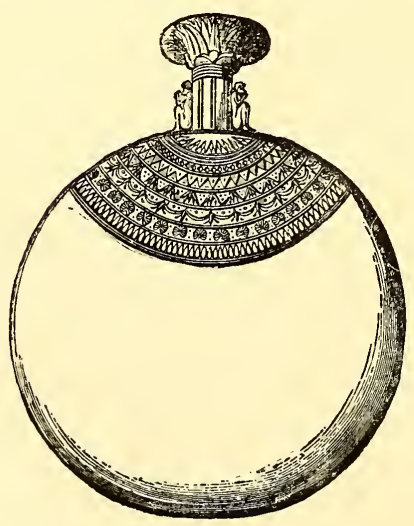

Fig. 229.

the purity of the contours or the clearness of the lines.

Glazed pottery was common from the earliest times. Cups with a foot (fig. 227), blue bowls, rounded at the bottom and decorated in black ink with mystic eyes, lotus flowers, fishes (fig. 228), and palm-leaves, date, as a rule, from the Eighteenth, Nineteenth, or Twentieth Dynasties. Lenticular ampullæ coated with a greenish glaze, flanked by two 
crouching monkeys for handles, decorated along the edge with pearl or egg-shaped ornaments, and round the body with elaborate collars (fig. 229), belong almost without exception to the reigns of Apries and Amasis. * Sistrum handles, saucers, drinkingcups in the form of a half-blown lotus, plates,

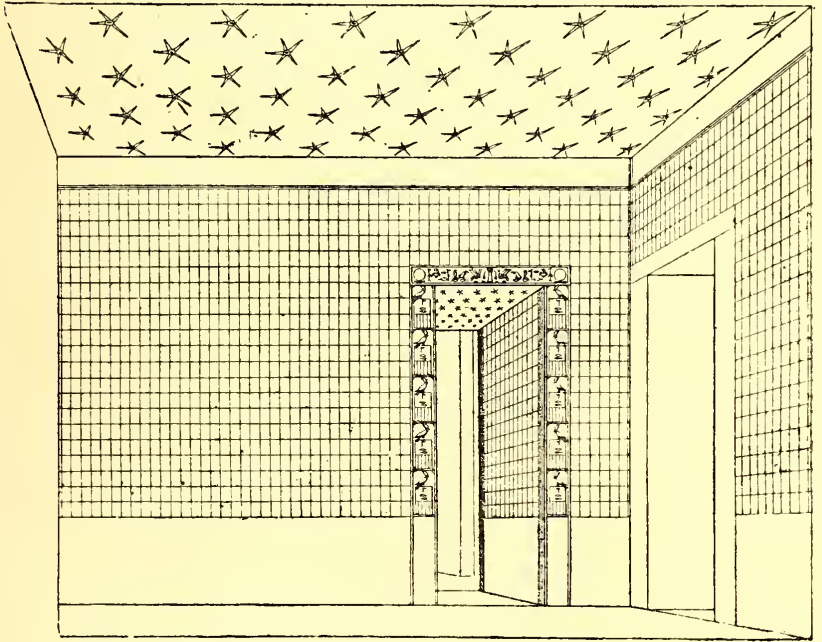

Fig. 230.

dishes-in short, all vessels in common use-were required to be not only easy to keep clean, but pleasant to look upon. Did they carry their taste for enamelled ware so far as to cover the walls of their houses with glazed tiles? Upon this point we can pronounce neither affirmatively nor negatively; the few examples of this kind of decoration which we possess

*Apries, in Egyptian "Uah-ab-Ra," the biblical "Hophra;" Amasis, Ahmes II. ; both of the Twenty-sixth Dynasty. [Translator's note.] 
being all from royal buildings. Upon a yellow brick, we have the family name and banner of Pepi I. ; upon a green brick, the name of Rameses III.; upon certain red and white fragments, the names of Seti I. and Sheshonk.

Up to the beginning of the present century, one of

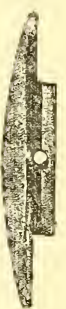
the chambers in the step pyramid at Sakkarah yet retained its mural decoration of glazed ware (fig. 230). For three-fourths of the wall-surface it was covered with green tiles, oblong in shape, flat at the back, and slightly convex on the face (fig. 23I). A square tenon, pierced through with a hole large enough to receive a wooden rod, served to Fig. 23I. fix them together in horizontal rows.* The three rows which frame in the doorway are inscribed with the titles of an unclassed Pharaoh belonging to one of the first Memphite dynasties. The hieroglyphs are relieved in blue, red, green, and yellow, upon a tawny ground. Twenty centuries later, Rameses III. originated a new style at Tell-el-Yahoodeh. This time the question of ornamentation concerned, not a single chamber, but a whole temple. The mass of the building was of limestone and alabaster; but the

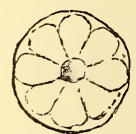

Fig. 232. pictorial subjects, instead of being sculptured according to custom, were of a kind of mosaic made with almost equal parts of stone tesseræ and glazed ware.

The most frequent item in the scheme of decoration was a roundel moulded of a sandy frit coated with

* Some specimens of these tiles may be seen in the Egyptian department at the British Museum. [Translator's note.] 
blue or grey slip, upon which is a cream-coloured rosette (fig. 232). Some of these rosettes are framed in geometrical designs (fig. 233) or spider-web patterns ; some represent open flowers. The central boss is in relief; the petals and tracery are encrusted in the mass. These roundels, which are of various diameters ranging from three-eighths of an inch to four inches, were fixed to the walls by means of a very fine cement. They were used to form many different designs, as scrolls, foliage, and parallel fillets, such as may be seen on the foot of an altar and the base of a

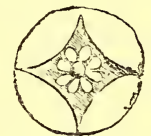

Fig. 233. column preserved in the Boulak Museum. The royal ovals were mostly in one piece; so also were the figures. The details, either incised or modelled upon the clay before firing, were afterwards painted with such colours as might be suitable. The lotus flowers and leaves which were carried along the bottom of the walls or the length

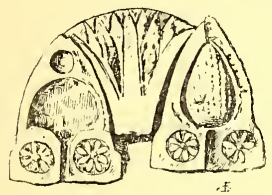

Fig. 234. of the cornices, were, on the contrary, made up of independent pieces; each colour being a separate morsel cut to fit exactly into the pieces by which it was surrounded (fig. 234). This temple was rifled at the beginning of the present century, and some figures of prisoners brought thence have been in the Louvre collection ever since the time of Champollion. All that remained of the building and its decoration was demolished a few years ago by certain dealers in antiquities, and the débris are now dispersed in all directions. Mariette, though with 
great difficulty, recovered some of the more important fragments, such as the name of Rameses III., which

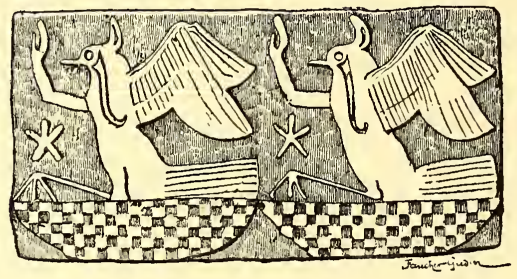

Fig. 235 .

dates the building; some borderings of lotus flowers and birds with human hands (fig. 235); and some heads of Asiatics and negro prisoners (fig. 236). * The destruction of this monument is the more grievous because the Egyptians cannot have constructed many after the same type. Glazed bricks, painted tiles, and enamelled mosaics are readily injured; and in the judgment of a people ena-

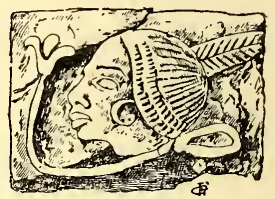

Fig. 236. moured of stability and eternity, that would be the gravest of radical defects.

\section{2.-WOOD, IVORY, LEATHER, AND TEXTILE FABRICS.}

Objects in ivory, bone, and horn are among the rarities of our museums; but we must not for this reason conclude that the Egyptians did not make ample use of those substances. Horn is perishable, and is eagerly devoured by certain insects, which

* We have a considerable number of specimens of these borderings, cartouches, and painted tiles representing foreign prisoners, in the British Museum; but the finest examples of the latter are in the Ambras Collection, Vienna. For a highly interesting and scholarly description of the remains found at Tell-el-Yahoodeh in 1870, see Professor Hayter Lewis's paper in vol. iii. of the Transactions of the Biblical Archæological Society. [Translator's note.] 
destroy it in no time. Bone and ivory soon deteriorate and become friable. The elephant was known to the Egyptians from the remotest period. They may, perhaps, have found it inhabiting the Thebaid when first they established themselves in that part of the Nile Valley, for as early as the Fifth Dynasty, we find the pictured form of the elephant in use as the hieroglyphic name of the island of Elephantine. Ivory in tusks and half tusks was imported into Egypt from the regions of the Upper Nile. It was sometimes dyed green or red, but was more generally left of its natural colour. It was largely employed by cabinet-makers for inlaying furniture, as chairs, bedsteads, and coffers. Combs, dice, hair-pins, toilette ornaments, delicately wrought spoons (fig. 237), collyrium bottles hollowed out of a miniature column surmounted by a capital, incense-burners in the shape of a hand supporting a bronze cup in which the perfumes were burned, and boomerangs engraved with figures of gods and fantastic animals, were also made of ivory. Some of these objects are works of fine art; as for instance, Fig. 237. at Boulak, a poignard-handle in the form of a lion; the plaques in bas-relief which adorn the draught-box of one Tuaï, who lived towards the end of the Seventeenth Dynasty; a Fifth Dynasty figure, unfortunately mutilated, which yet retains traces of rose colour; and a miniature statue of Abi, who died at the time of the Thirteenth Dynasty. This little personage, perched on the top of a lotus-flower column, looks straight before him with a majestic air which contrasts somewhat 
comically with the size and prominence of his ears. The modelling of the figure is broad and spirited, and will bear comparison with good Italian ivories of the Renaissance period.

Egypt produces few trees, and of these few the greater number are useless to the sculptor. The two which most abound-namely, the date palm and the Dôm palm-are of too coarse a fibre for carving, and are too unequal in texture. Some varieties of the sycamore and acacia are the only trees of which the grain is sufficiently fine and manageable to be wrought with the chisel. Wood was, nevertheless, a favourite material for cheap and rapid work. It was even employed at times for subjects of importance, such as Ka statues; and the Wooden Man of Boulak shows with what boldness and amplitude of style it could be treated. But the blocks and beams which the Egyptians had at command were seldom large enough for a statue. The Wooden Man himself, though but half life-size, consists of a number of pieces held together by square pegs. Hence, wood-carvers were wont to treat their subjects upon such a scale as admitted of their being cut in one block, and the statues of olden time became statuettes under the Theban dynasties. Art lost nothing by the reduction, and more than one of these little figures is comparable to the finest works of the ancient empire. The best, perhaps, is at the Turin Museum, and dates from the Twentieth Dynasty. It represents a young girl whose only garment is a slender girdle. She is of that indefinite age when the undeveloped form is almost as much like that of a boy as of a girl. The expression of the head is gentle, yet 
saucy. It is, in fact, across thirty centuries of time, a portrait of one of those graceful little maidens of Elephantine, who, without immodesty or embarrassment, walk unclothed in sight of strangers. Three little wooden men in the Boulak Museum are probably con-

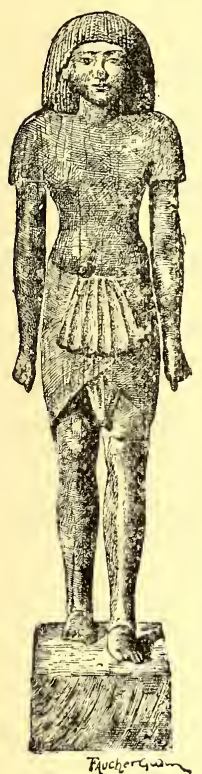

Fig. 238 . temporaries of the Turin figure. They wear full dress, as, indeed, they should, for one was a king's favourite named Hori, whose surname was Ra. They are walking with calm and measured tread, the bust thrown forward, and the head high. The expression upon their faces is knowing, and somewhat sly. An officer who has retired on halfpay at the Louvre (fig. 238) wears an undress uniform of the time of Amenhotep III. ; that is to say, a light wig, a close-fitting vest with

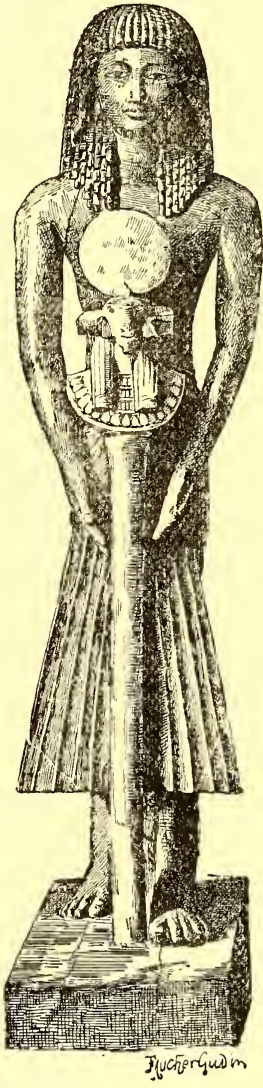

Fig, 239. short sleeves, and a kilt drawn tightly over the hips, reaching scarcely half-way down the thigh, and trimmed in front with a piece of puffing plaited longwise. His 
companion is a priest (fig. 239) who wears his hair in rows of little curls one above the other, and is clad in a long petticoat falling below the calf of the leg and spreading out in front in a kind of plaited apron. He holds a sacred standard consisting of a stout staff surmounted by a ram's head crowned with the solar disk. Both officer and priest are painted red brown, with the exception of the hair, which is black;

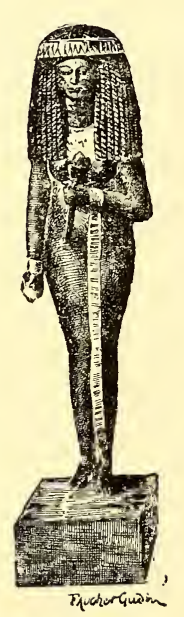

Fig. 240. the cornea of the eyes, which is white; and the standard, which is yellow. Curiously enough, the little lady Naï, who inhabits the same glass case, is also painted reddish brown, instead of buff, which was the canonical colour for women (fig. 240). She is taken in a close-fitting garment trimmed down the front with a band of white embroidery. Round her neck she wears a necklace consisting of a triple row of gold pendants. Two golden bracelets adorn her wrists, and on her head she carries a wig with long curls. The right arm hangs by her side, the hand holding some object now lost, which was probably a mirror. The left arm is raised, and with the left hand she presses a lotus lily to her breast. The body is easy and well formed, the figure indicates youth, the face is open, smiling, pleasant, and somewhat plebeian. To modify the unwieldy mass of the headdress was beyond the skill of the artist, but the bust is delicately and elegantly modelled, the clinging garment gives discreet emphasis to the shape, and the action 
of the hand which holds the flower is rendered with grace and naturalness. All these are portraits, and as the sitters were not persons of august rank, we may conclude that they did not employ the most fashionable artists. They, doubtless, had recourse to more unpretending craftsmen; but that such craftsmen were thus highly trained in knowledge of form and accuracy of execution, shows how strongly even the artizan was influenced by the great school of sculpture which then flourished at Thebes.

This influence becomes even more apparent when we study the knick-knacks of the toilet table, and such small objects as, properly speaking, come under the head of furniture. To pass in review the hundred and one little articles of female ornament or luxury to which the fancy of the designer gave all kinds of ingenious and novel forms, would be no light task. The handles of mirrors, for instance, generally represented a stem of lotus or papyrus surmounted by a full-blown flower, from the midst of which rose a disk of polished metal. For this design is sometimes substituted the figure of a young girl, either nude, or clad in a close-fitting garment, who holds the mirror on her head. The tops of hair-pins were carved in the semblance of a coiled serpent, or of the head of a jackal, a dog, or a hawk. The pin-cushion in which they are placed is a hedgehog or a tortoise, with holes pierced in a formal pattern upon the back. The head-rests, which served for pillows, were decorated with bas-reliefs of subjects derived from the myths of Bes and Sekhet, the grimacing features of the former deity being carved on the ends or on the base. But it is in the carving of perfume-spoons and kohl- 
bottles that the inventive skill of the craftsman is most

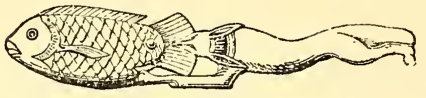

Fig. 24I. brilliantly displayed.

Not to soil their fingers, the Egyptians made use of spoons for essences, pomades, and the variously-coloured preparations with which both men and women stained their cheeks, lips, eyelids, nails, and palms. The designer generally borrowed his subjects from the fauna or flora of the Nile valley. An etui-case at Boulak is carved in the shape of a couchant calf, the body being hollowed out, and the head and back lifting off to form the lid. A spoon in the same collection represents a dog running away with an enormous fish in his mouth (fig. 24I), the body of the fish forming the bowl of the spoon. Another shows a cartouche springing from a full-blown Fig. 242. lotus; another, a lotus fruit laid upon a bouquet of

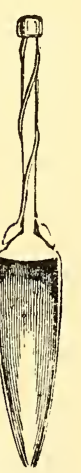
flowers (fig. 242); and here is a simple triangular bowl, the handle decorated with a stem and two buds (fig. 243). The most elaborate specimens combine these subjects with the human figure. A young girl, clad in a mere girdle, is represented in the act of swimming (fig. 244). Her head is well lifted above the water, and her outstretched arms support a duck, the body of which is hollowed out, while the wings, being movable, serve as a cover. We have also a young girl in the Fig. 243. Louvre collection, but she stands in a maze of lotus plants, and is in the act of gathering a 
bud. A bunch of stems, from which emerge two fullblown blossoms, unites the handle to the bowl of the spoon, which is in reverse position, the larger end being

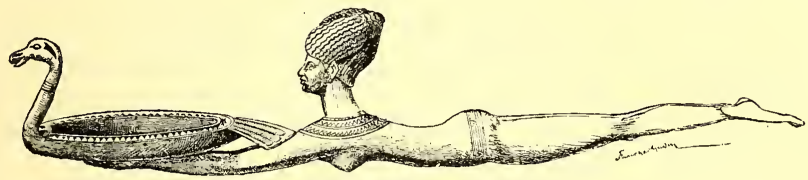

Fig. 244 .

turned outwards and the point inwards. Elsewhere, a young girl (fig. 246) playing upon a long-necked lute as she trips along, is framed in by two flowering stems. Sometimes the fair musician is standing upright in a tiny skiff (fig. 247); and sometimes a girl

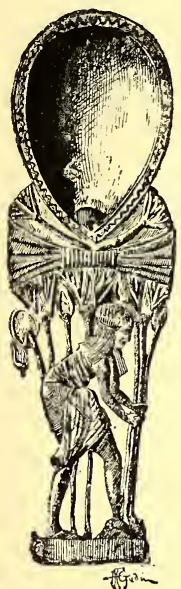

Fig. 245 . bearing offerings is substitued for the lute player. Another exarnple represents a slave toiling under the weight of an enormous sack. The age and physi ognomy of each of these personages is clearly indicated. The lotus gatherer is of good birth, as may be seen by her carefully plaited hair and tunic. The Theban ladies wore long robes; but this damsel has gathered up her

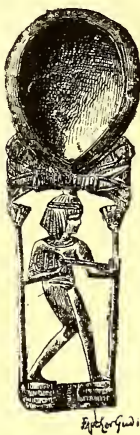

Fig. 246. skirts that she may thread her way among the reeds without wetting her garments. The two musicians and the swimming girl belong, on the contrary, to an inferior, or servile, class. Two of them wear only a girdle, and 
the third has a short garment negligently fastened. The bearer of offerings (fig. 248) wears the long pendent tresses distinctive of childhood, and is one of those slender, growing girls of the Fellaheen class whom one sees in such numbers on the banks of the Nile. Her lack of clothing is, however, no evidence of want of birth, for not even the children of nobility were wont to put on the garments of their sex before the period of adolescence. Lastly,

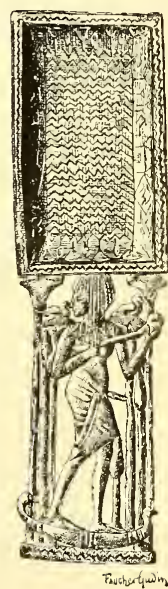

Fig. 247. the slave (fig. 249), with his thick lips, his high shoulders, his flat nose, his heavy, animal jaw, his low brow, and his bare, conical head, is evidently a caricature of some foreign prisoner. The dogged sullenness with which he trudges under his burden is admirably caught, while the angularities of the body, the type of the head, and the general arrangement of the parts, remind one of the terra-cotta

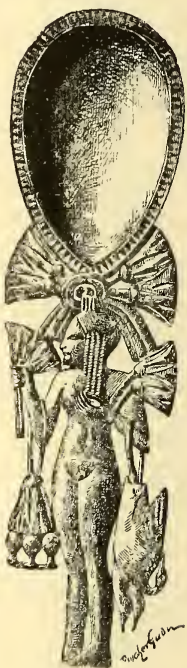

Fig. 248. grotesques of Asia Minor. In these subjects, all the minor details, the fruits, the flowers, the various kinds of birds, are rendered with much truth and cleverness. Of the three ducks which are tied by the feet and slung over the arms of the girl bearing offerings, two are resigned to their fate, and hang swinging with open eyes and outstretched necks; but the third flaps her wings and 
lifts her head protestingly. The two small water-fowl perched upon the lotus flowers listen placidly to the lute-player's music, their beaks resting on their crops. They have learned by experience not to put themselves out of the way for a song, and they know that there is nothing to fear from a young girl, unless she is armed. They are put to flight in the basreliefs by the mere sight of a bow and arrows, just as a company of rooks is put to flight nowadays by the sight of a gun. The Egyptians were especially familiar with the ways of animals and birds, and reproduced them with marvellous exactness. The habit of minutely observing minor facts became instinctive, and it informed their most trifling works with that air of reality which strikes us so forcibly at the present day.

Household furniture was no more abundant in ancient Egypt than it is in the Egypt of to-day. For the poor, there were a few mats of plaited reeds and some mud-built bins ; for middleclass folk, a linen-chest and a few stools. It was only the rich who

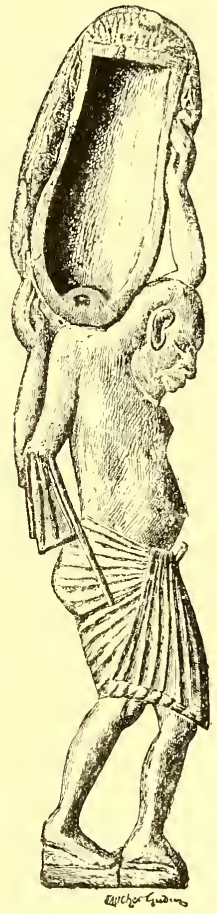

Fig. 249. possessed bedsteads, arm-chairs, divans, and tables. Most of our modern furniture, such as cupboards, sideboards, dressers, and chests of drawers, was unknown. The art of the cabinet-maker was nevertheless carried to a high degree of perfection, from the time of the 
ancient dynasties. Planks were dressed down with the adze, morticed, glued, joined together by means of pegs cut in hard wood or acacia thorns (never by

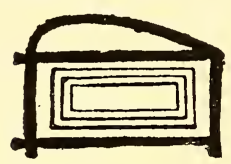

Fig. 250. metal nails), polished, and finally covered with paintings. Chests generally stand upon four straight legs, and are sometimes thus raised at some height from the ground. The lid is flat, or rounded according to a special curvature (fig. 250) much in favour among the Egyptians of all periods. Sometimes, though rarely, it is gable-shaped, like our house-roofs (fig. 25I). Generally speaking, the lid lifts off bodily; but it often turns upon a peg inserted in one of the uprights. Sometimes, also, it turns

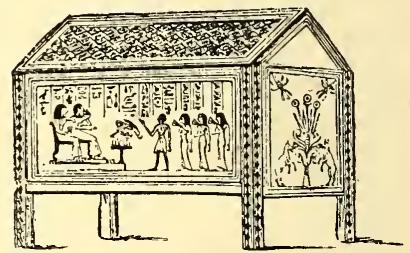

Fig. 25 I. upon wooden pivots (fig. 252). The panels, which are large and admirably suited for decorative art, are enriched with paintings, or inlaid with ivory, silver,

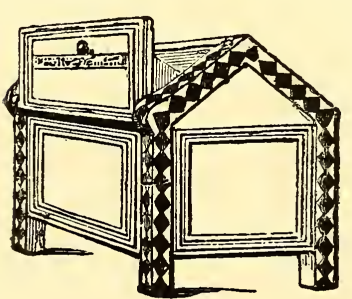

Fig. 252. precious woods, or enamelled plaques. It may be that we are scarcely in a position justly to appraise the skill of Egyptian cabinet-makers, or the variety of designs produced at various periods. Nearly all the furniture which has come down to our day has been found in tombs, and, being destined for burial in the sepulchre, may either be of a character exclusively destined for the use of the mummy, or 
possibly a cheap imitation of a more precious class of goods.

The mummy was, in fact, the cabinet-maker's best customer. Everywhere else, man took but a few objects with him into the next world; but the defunct Egyptian was content with nothing short of a complete outfit. The mummy-case alone was an actual monument, in the construction of which a whole squad of workmen was employed (fig. 253). The styles of mummy-cases varied from period to period. Under the Memphite and first Theban empires, we find only rectangular chests in sycamore wood, flat at

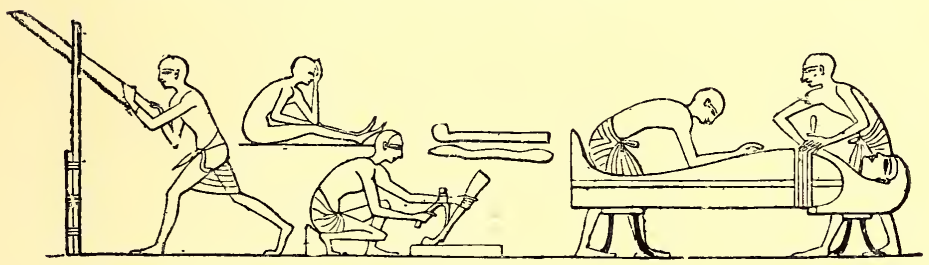

Fig. 253.

top and bottom, and made of many pieces joined together by wooden pins. The pattern is not elegant, but the decoration is very curious. The lid has no cornice. Outside, it is inscribed down the middle with a long column of hieroglyphs, sometimes merely written in ink, sometimes laid on in colour, sometimes carved in incuse characters filled in with some kind of bluish paste. The inscription records only the name and titles of the deceased, accompanied now and then by a short form of prayer in his favour. The inside is covered with a thick coat of stucco or whitewash. Upon this surface, the seventeenth chapter of The Book 
of the Dead was generally written in red and black inks, and in fine cursive hieroglyphs. The body of the chest is made with three horizontal planks for the bottom, and eight vertical planks, placed two and two, for the four sides. The outside is sometimes decorated with long strips of various colours ending in interlaced lotus-leaves, such as are seen on stone sarcophagi. More frequently, it is ornamented on the left side with two wideopen eyes and two monumental doors, and on the right with three doors exactly like those seen in contemporary catacombs. The sarcophagus is in truth the house of the deceased; and, being his house, its four walls were bound to contain an epitome of the prayers and tableaux which covered the walls of his tomb. The necessary formulæ and pictured scenes were, therefore, reproduced inside, nearly in the same order in which they appear in the mastabas. Each side is divided in three registers, each register containing a dedication in the name of the deceased, or representations of objects belonging to him, or such texts from the Ritual as need to be repeated for his benefit. Skilfully composed, and painted upon a background in imitation of some precious wood, the whole forms a boldlydesigned and harmoniously-coloured picture. The cabinet-maker's share of the work was the lightest, and the long boxes in which the dead of the earliest period were buried made no great demand upon his skill. This, however, was not the case when in later times the sarcophagus came to be fashioned in the likeness of the human body. Of this style we have two leading types. In the most ancient, the mummy serves as the model for his case. His outstretched feet and legs are 
in one. The form of the knee, the swell of the calf, the contours of the thigh and the trunk, are summarily indicated, and are, as it were, vaguely modelled under the wood. The head, apparently the only living part of this inert body, is wrought out in the round. The dead man is in this wise imprisoned in a kind of statue of himself; and this statue is so well balanced that it can stand on its feet if required, as upon a pedestal. In the other type of sarcophagus, the deceased lies at full length upon his tomb, and his figure, sculptured in the round, serves as the lid of his mummy-case. On his head is seen the ponderous wig of the period. A white linen vest and a long petticoat cover his chest and legs. His feet are shod with elegant sandals. His arms lie straight along his sides, or are folded upon his breast, the hands grasping various emblems, as the "ankh,"* the belt-buckle, $\uparrow$ the "Tat;" $\ddagger$ or, as in the case of the wife of Sennotmou at Boulak, a garland of ivy. This mummiform type of sarcophagus is rarely met with under the Memphite dynasties, though Menkara, the Mycerinus of the Greeks, affords a memorable example. Under the Eleventh Dynasty, the mummy-case is frequently but a hollowed tree-trunk, roughly sculptured outside, with a head at one end and feet at the other. The face is daubed with bright colours, yellow, red, and green; the wig and head-dress are striped with black and blue, and an elaborate collar is depicted on

* The ankh, sometimes called the "Tau-Cross," was an amulet emblematic of life eternal.

† The "belt-buckle," or $T a$ amulet, placed the deceased under the protection of Isis.

† The Tat amulet was the emblem of stability. [Translator's note.] 
the breast. The rest of the case is either covered with the long, gilded wings of Isis and Nephthys, or covered with a uniform tint of white or yellow, and sparsely decorated with symbolic figures, or columns of hieroglyphs painted blue and black. Among those sarcophagi belonging to kings of the Seventeenth Dynasty

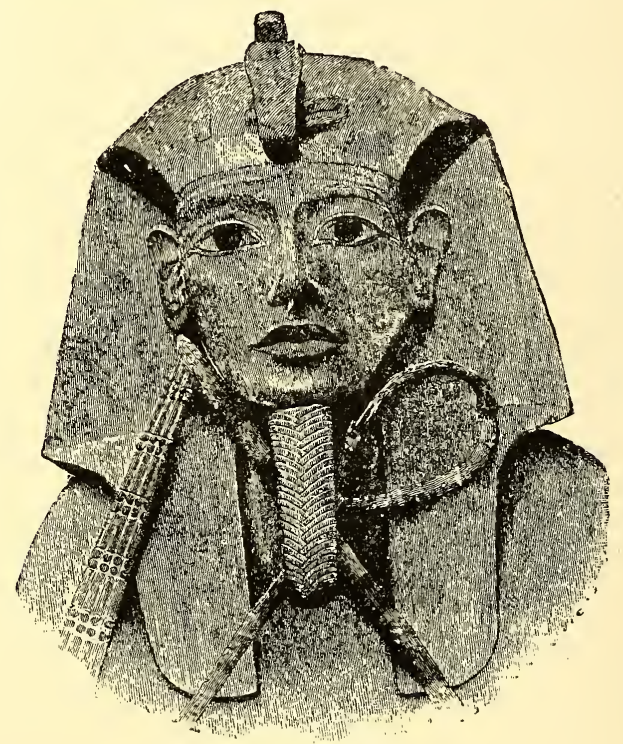

Fig. 254 .

which I recovered from Dayr-el-Baharee, the most highly finished belonged to this type, and were only remarkable for the really extraordinary skill with which the craftsman had reproduced the features of the deceased sovereigns. The mask of Ahmes I., that of Amenhotep I., and that of Thothmes II., are masterpieces in their way. The mask of 
Rameses II. shows no sign of paint, except a black line which accentuates the form of the eye. The face is doubtless modelled in the likeness of the Pharaoh Her-Hor, who restored the funerary outfit of his puissant ancestor, and it will almost bear comparison with the best works of contemporary sculpture (fig. 254). Two mummy-cases found in the same place-namely, those of Queen Ahmes-Nefertari and her daughter, Aah-hotep II.-are of gigantic size, and measure more than ten and a half feet in height (fig. 255). Standing upright, they might almost be taken for two of the caryatid statues from the first court at Medinet Haboo, though on a smaller scale. The bodies are represented as bandaged, and but vaguely indicate the contours of the human form. The shoulders and bust of each are covered with a kind of network in relief, every mesh standing out in blue upon a yellow ground. The hands emerge from this mantle, are crossed upon the breast, and grasp the "Ankh," or Tau-cross, symbolic of eternal life. The heads are portraits. The faces are round, the eyes large, the expression mild and charac-

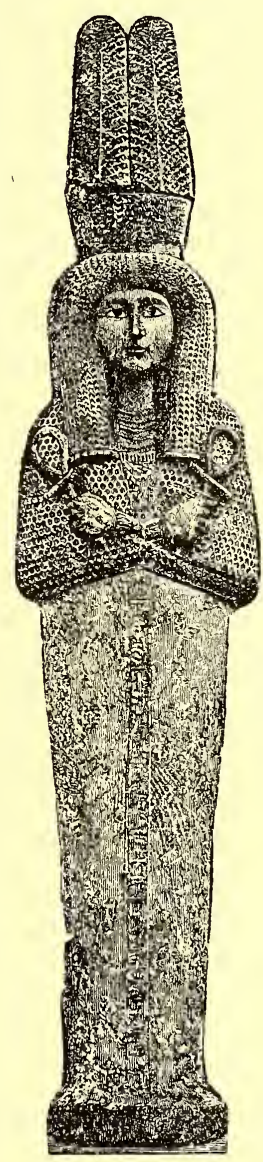

Fig. 255 .

Mumay-case of Queen AHMES-NEFERTARI. terless. Each is crowned with the flat-topped cap and 
lofty plumes of Amen or Maut. We cannot but wonder for what reason these huge receptacles were made. The two queens were small of stature, and their mummieswhich were well-nigh lost in the cases-had to be packed round with an immense quantity of rags, to prevent them from shifting, and becoming injured. Apart from their abnormal size, these cases are characterised by the same simplicity which distinguishes other mummycases of royal or private persons of the same period. Towards the middle of the Nineteenth Dynasty, the fashion changed. The single mummy-case, soberly decorated, was superseded by two, three, and even four cases, fitting the one into the other, and covered with paintings and inscriptions. Sometimes the outer receptacle is a sarcophagus with convex lid and square ears, upon which the deceased is pictured over and over again upon a white ground, in adoration before the gods of the Osirian cycle. When, however, it is shaped in human form, it retains somewhat of the old simplicity. The face is painted; a collar is represented on the chest; a band of hieroglyphs extends down the whole length of the body to the feet; and the rest is in one uniform tone of black, brown, or dark yellow. The inner cases were extravagantly rich, the hands and faces being red, rose-coloured, or gilded ; the jewellery painted, or sometimes imitated by means of small morsels of enamel encrusted in the wood-work; the surfaces frequently covered with many-coloured scenes and legends, and the whole heightened by means of the yellow varnish already mentioned. The lavish ornamentation of this period is in striking contrast with the sobriety of earlier times; but in order to grasp 
the reason of this change, one must go to Thebes, and visit the actual sepulchres of the dead. The kings and private persons of the great conquering dynasties* devoted their energies, and all the means at their disposal, to the excavation of catacombs. The walls of those catacombs were covered with sculptures and paintings. The sarcophagus was cut in one enormous block of granite or alabaster, and admirably wrought. It was therefore of little moment if the wooden coffin in which the mummy reposed were very simply decorated. But the Egyptians of the decadence, and their rulers, had not the wealth of Egypt and the spoils of neighbouring countries at command. They were poor; and the slenderness of their resources debarred them from great undertakings. They for the most part gave up the preparation of magnificent tombs, and employed such wealth as remained to them in the fabrication of fine mummy-cases carved in sycamore wood. The beauty of their coffins, therefore, but affords an additional proof of their weakness and poverty. When for a few centuries the Saite princes had succeeded in re-establishing the prosperity of the country, stone sarcophagi came once more into requisition, and the wooden coffin reverted to somewhat of the simplicity of the great period. But this Renaissance was not destined to last. The Macedonian conquest brought back the same revolution in funerary fashions which followed the fall of the Ramessides. Double and triple mummy cases, over-painted and over-gilded, were again in demand; and if the craftsmen of Græco-Roman time who attired the dead

* That is, the Eighteenth and Nineteenth Dynasties. [Translator's note. $]$ 
of Ekhmeem for their last resting-places were less skilful than those of earlier date, their bad taste was, at all events, not surpassed by the Theban coffin-makers who lived and worked under the latest princes of the royal line of Rameses.

The remainder of the funerary outfit supplied the cabinet-maker with as much work as the coffin-maker. Boxes of various shapes and sizes were required for the wardrobe of the mummy, for his viscera, and for his funerary statuettes. He must also have tables for his meals, stools, chairs, a bed to lie upon, a sledge to convey him to the tomb, and sometimes even a warchariot and a carriage in which to take the air.* The boxes for canopic vases, funerary statuettes, and libation-vases, are divided in several compartments. A couchant jackal is sometimes placed on the top, and serves for a handle by which to take off the lid. Each box was provided with its own little sledge, upon which it was drawn in the funeral procession on the day of burial. Beds are not very uncommon. Many are identical in structure with the Nubian angarebs of the present day, and consist merely of some coarse fabric, or of interlaced strips of leather, stretched on a plain wooden frame. Few exceed fifty-six inches in ength; the sleeper, therefore, could never lie outstretched, but must perforce assume a doubled-up position. The frame is generally horizontal, but sometimes it slopes slightly downwards from the head to the foot. It was often raised to a considerable height above the

* There is a fine specimen of one of these sledges in the Leyden Museum, and the Florentine Museum contains a celebrated Egyptian war-chariot in fine preservation. [Translator's note.] 
level of the floor, and a stool, or a little portable set of steps, was used in mounting it. These details would have been known to us only by the wall-paintings, had I not myself discovered two perfect specimens in I884 and I 885; one at Thebes, in a tomb of the Thirteenth Dynasty, and the other at Ekhmeem, in the GræcoRoman necropolis. In the former, two accommodating

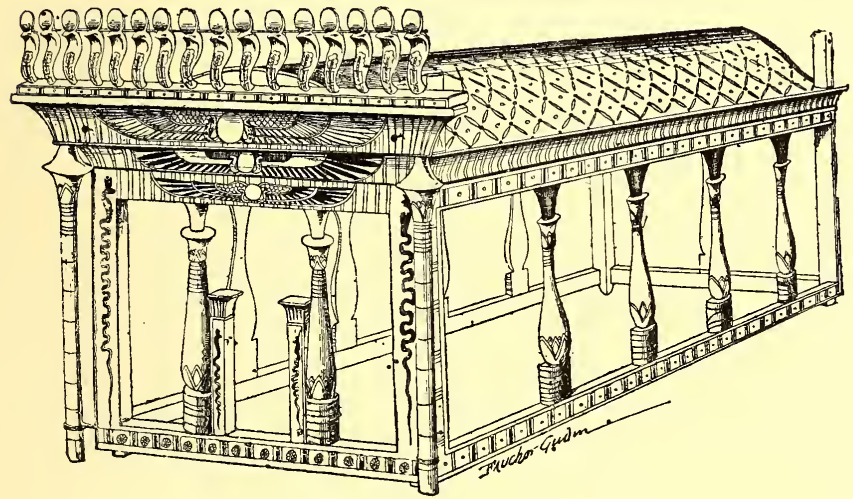

Fig. 256.

lions have elongated their bodies to form the framework, their heads doing duty for the head of the bed, and their tails being curled up under the feet of the sleeper. The bed is surmounted by a kind of canopy, under which the mummy lay in state. Rhind had already found a similar canopy, which is now in the Museum of Edinburgh* (fig. 256). In shape it is a temple, the rounded roof being supported by elegant colonnettes

* See the coloured frontispiece to Thebes; $2 t s$ Tombs and their Tenants, by A. H. Rhind. I862. [Translator's note.] 
of painted wood. A doorway guarded by serpents is supposed to give access to the miniature edifice. Three winged discs, each larger than the one below it, adorn three superimposed cornices above the door, the whole frontage being surmounted by a row of erect uræi, crowned with the solar disk. The canopy belonging to the Thirteenth Dynasty bed is much more simple, being a mere balustrade in cut and painted wood, in imitation of the water-plant pattern with which temple walls were decorated; the whole crowned with an ordinary cornice. In the bed of Græco-Roman date (fig. 257),

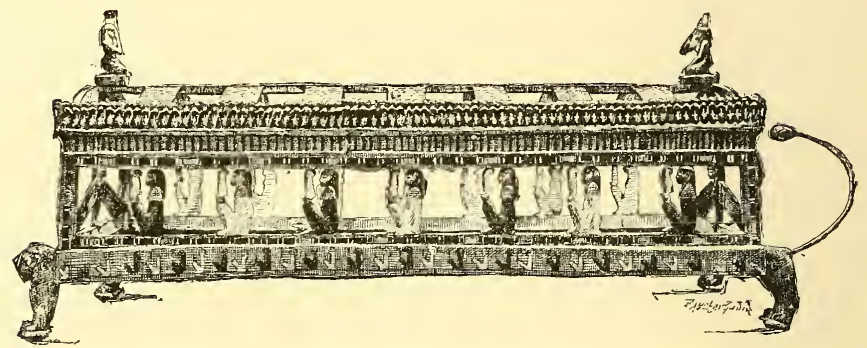

Fig. 257 .

carved and painted figures of the goddess $\mathrm{Ma}$, sitting with her feather on her knee, are substituted for the customary balustrades. Isis and Nephthys stand with their winged arms outstretched at the head and foot. The roof is open, save for a row of vultures hovering above the mummy; while two kneeling statuettes of Isis and Nephthys weep over it, one at each end. The sledges upon which mummies were dragged to the sepulchre were also furnished with canopies, but in a totally different style. The sledge canopy is a panelled shrine, like those which I discovered in I886, in the 
tomb of Sennotmou at Koornet Murraee. If light was admitted, it came through a square opening, showing the head of the mummy within. Wilkinson gives an illustration of a sledge canopy of this kind, from the wall paintings of a Theban tomb (fig. 258). The panels were always made to slide. As soon as the mummy was

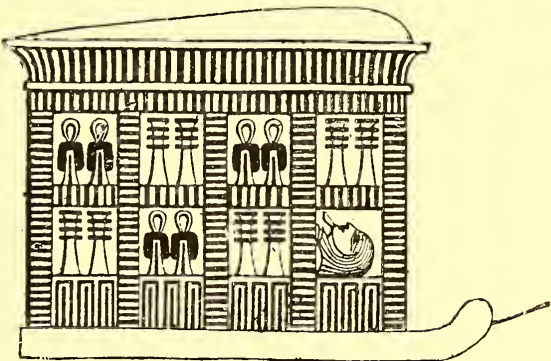

Fig. 258. laid upon his sledge, the panels were closed, the corniced roof placed over all, and the whole closed in. With regard to chairs, many of those in the Louvre and the

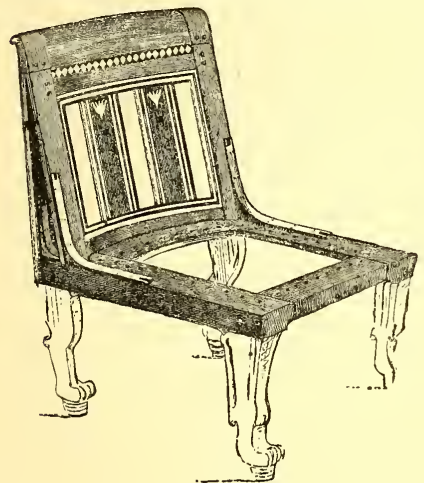

Fig. 259. British Museum were made about the time of the Eleventh Dynasty. These are not the least beautiful specimens which have come down to us, one in particular (fig. 259) having preserved an extraordinary brilliancy of colour. The framework, formerly fitted with a seat of strong netting, was originally supported on four legs with lions' feet. The back is ornamented with two lotus flowers, and with a row of lozenges inlaid in ivory and ebony upon a red ground. Stools of similar workmanship (fig. 260), and 
folding stools, the feet of which are in the form of a

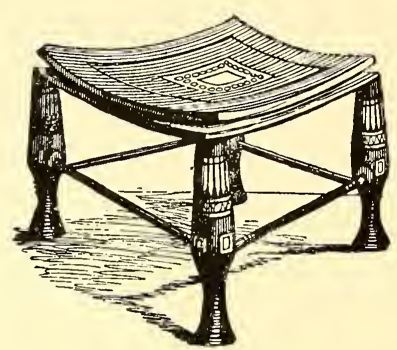

Fig. 260. goose's head, may be seen in all museums. Pharaohs and persons of high rank affected more elaborate designs. Their seats were sometimes raised very high, the arms being carved to resemble running lions, and the lower supports being prisoners of war, bound back to back (fig. 26I). A footboard in front served as a step to mount by, and as a footstool when seated. Up to the present time, we have found no specimens of this kind of seat.*

We learn from the tomb paintings that netted or cane-bottomed chairs were covered with stuffed seats and richly worked cushions. These cushions and stuffed seats have perished, but it is to be concluded that they were covered

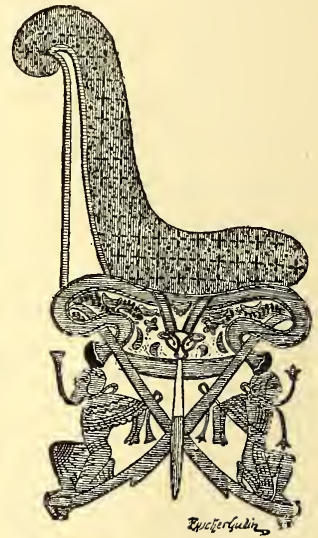

Fig. 26I. with tapestry. Tapestry was undoubtedly known to

* Since the publication of this work in the original French, a very splendid specimen of a royal Egyptian chair of state, the property of Jesse Haworth, Esq., has been placed on view at the Manchester Jubilee Exhibition. It is made of dark wood, apparently rosewood; the legs being shaped like bull's legs, having silver hoofs, and a solid gold cobra snake twining round each leg. The arm-pieces are of light wood with cobra snakes carved upon the flat in low relief, each snake covered with hundreds of small silver annulets, to represent the markings of the reptile. For a more minute description see The 
the Egyptians, and a bas-relief subject at BeniHassan (fig. 262)* shows the process of weaving it. The frame, which is of the simplest structure, resembles that now in use among the weavers of Ekhmeem. It is horizontal, and is formed of two slender cylinders, or rather of two rods, about fifty-four inches apart, each held in place by two large pegs driven into the ground about three feet distant from

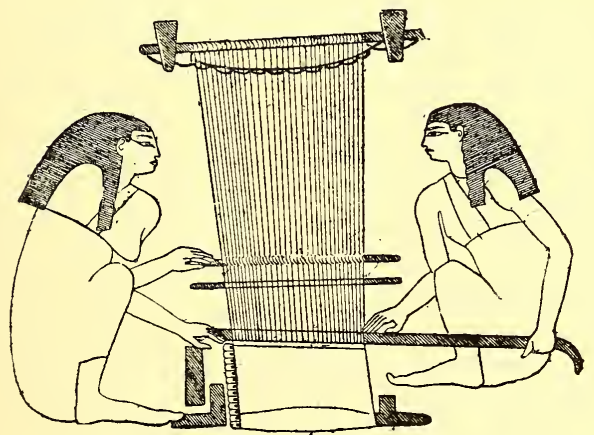

Fig. 262.

each other. The warps of the chain were strongly fastened, then rolled round the top cylinder till they were stretched sufficiently tight. Mill sticks placed at certain distances facilitated the insertion of the needles which carried the thread. As in the Gobelins factory, the work was begun from the bottom. The texture was regulated and equalised by means of a coarse comb, and was rolled upon the lower cylinder as it increased

Times, June 22nd, 1887. This chair, dated by a fragment of a royal cartouche, belonged to Queen Hatshepsu, of the Eighteenth Dynasty. [Translator's note.]

* In this cut, as well as in the next, the loom is represented as if upright; but it is supposed to be extended on the ground. [Translator's note.] 
in length. Hangings and carpets were woven in this manner; some with figures, others with geometrical designs, zigzags, and chequers (fig. 263). A careful examination of the monuments has, however, convinced me that most of the subjects hitherto supposed to represent examples of tapestry represent, in fact, examples of cut and painted leather. The leather-worker's craft flourished in ancient Egypt. Few museums are without a pair of leather sandals, or a specimen of mummy braces with ends of stamped leather bearing

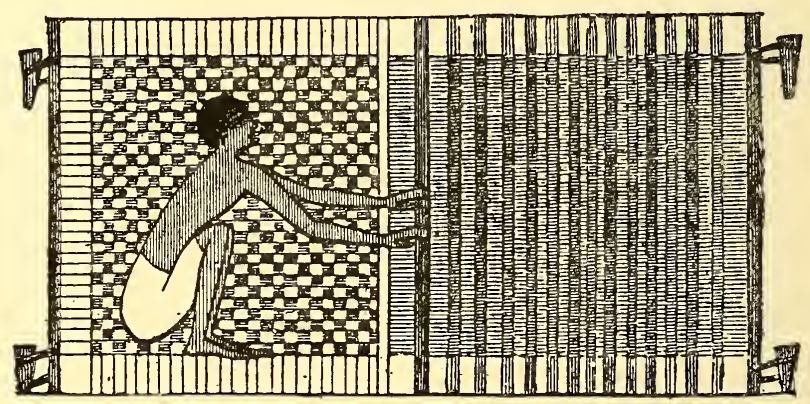

Fig. 263.

the effigy of a god, a Pharaoh, a hieroglyphic legend, a rosette, or perhaps all combined. These little relics are not older than the time of the priest-kings, or the earlier Bubastites. It is to the same period that we must attribute the great cut-leather canopy in the Boulak Museum. The catafalque upon which the mummy was laid when transported from the mortuary establishment to the tomb, was frequently adorned with a covering made of stuff or soft leather. Sometimes the sidepieces hung down, and sometimes they were drawn aside with bands, like curtains, and showed the coffin. 
The canopy of Dayr-el-Baharee was made for the Princess Isi-em-Kheb, daughter of the High Priest Masahirti, wife of the High Priest Menkheperra, and mother of the High Priest Pinotem III. The centrepiece, in shape an oblong square, is divided into three bands of sky-blue leather, now faded to pearl-grey. The two side-pieces are sprinkled with yellow stars. Upon the middle piece are rows of vultures, whose outspread wings protect the mummy. Four other pieces covered with red and green chequers are attached to the ends and sides. The longer pieces which hung over the sides are united to the centre-piece by an ornamental bordering. On the right, scarabæi with extended wings alternate with the cartouches of King Pinotem II., and are surmounted by a lance-head frieze. On the left side, the pattern is more complicated (fig. 264). In the centre we see a bunch of lotus lilies flanked by royal cartouches. Next come two antelopes, each kneeling upon a basket; then two bouquets of papyrus; then two more scarabæi,

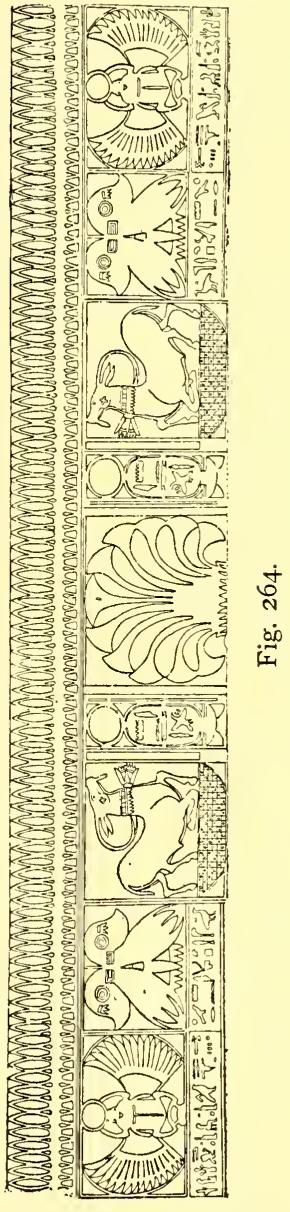
similar to those upon the other border. The lance-head frieze finishes it above, as on the opposite side. The 
technical process is very curious. The hieroglyphs and figures were cut out from large pieces of leather; then, under the open spaces thus left, were sewn thongs of leather of whatever colour was required for those ornaments or hieroglyphs. Finally, in order to hide the patchwork effect presented at the back, the whole was lined with long strips of white, or light yellow, leather. Despite

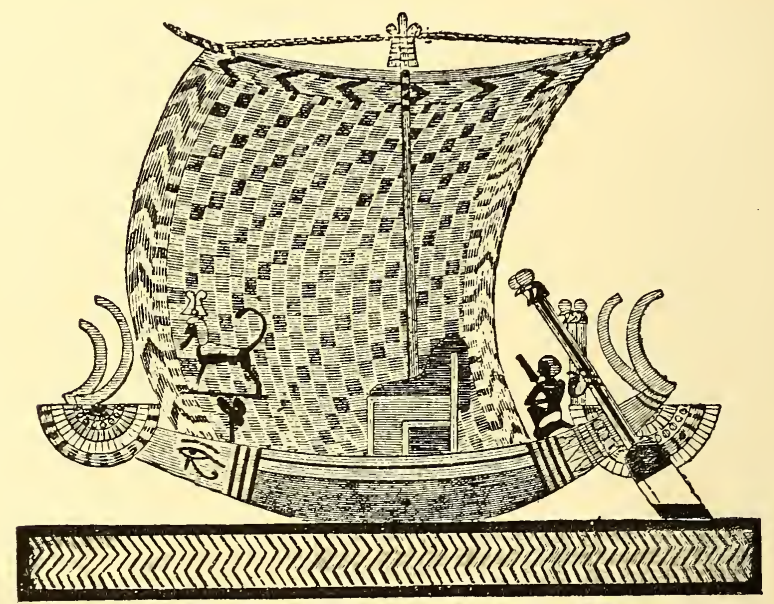

Fig. 265 .

the difficulties of treatment which this work presented, the result is most remarkable.* The outlines of the gazelles, scarabæi, and flowers are as clean-cut and as elegant as if drawn with the pen upon a wall-surface or a page of papyrus. The choice of subjects is happy, and the colours employed are both lively and harmonious.

* For a chromolithographic reproduction of this work as a whole, with drawings of the separate parts, facsimiles of the inscriptions, etc., see "The Funeral Tent of an Egyptian Queen," by H. Villiers Stuart. 
The craftsmen who designed and executed the canopy of Isi-em-Kheb had profited by a long experience of this system of decoration, and of the kind of patterns suitable to the material. For my own part, I have not the slightest doubt that the cushions of chairs and royal couches, and the sails of funerary and sacred boats used for the transport of mummies and divine images, were

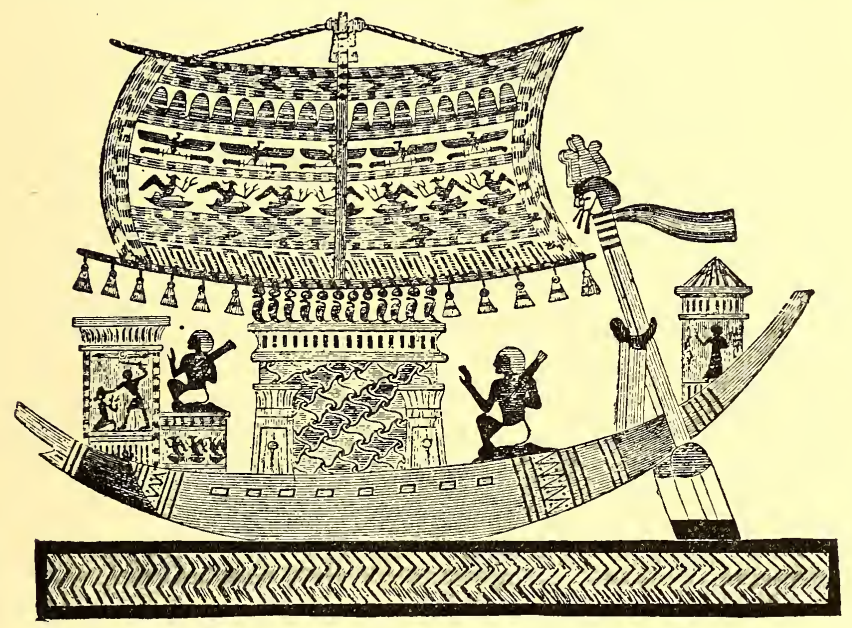

Fig. 266.

most frequently made in leather-work. The chequerpatterned sail represented in one of the boat subjects painted on the wall of a chamber in the tomb of Rameses III. (fig. 265), might be mistaken for one of the side pieces of the canopy at Boulak. The vultures and fantastic birds depicted upon the sails of another boat (fig. 266) are neither more strange nor more difficult to make in cut leather than the vultures and gazelles of Isi-em-Kheb. 
We have it upon the authority of ancient writers that the Egyptians of olden time embroidered as skilfully as those of the Middle Ages. The surcoats given by Amasis, one to the Lacedæmonians, and the other to the temple of Athena at Lindos, were of linen embroidered with figures of animals in gold thread and purple, each thread consisting of three hundred and sixty-five distinct filaments. To go back to a still earlier period, the monumental tableaux show portraits of the Pharaohs wearing garments with borders, either woven or embroidered, or done in appliqué work. The most simple patterns consist of one or more stripes of brilliant colour parallel with the edge of the material. Elsewhere we see palm patterns, or rows of disks and points, leaf-patterns, meanders, and even, here and there, figures of men, gods, or animals, worked most probably with the needle. None of the textile materials yet found upon royal mummies are thus decorated; we are therefore unable to pronounce upon the quality of this work, or the method employed in its production. Once only, upon the body of one of the Dayr-el-Baharee princesses, did I find a royal cartouche embroidered in pale rose-colour. The Egyptians of the best periods seem to have attached special value to plain stuffs, and especially to white ones. These they wove with marvellous skill, and upon looms in every respect identical with those used in tapestry work. Those portions of the winding sheet of Thothmes III. which enfolded the royal hands and arms, are as fine as the finest India muslin, and as fairly merit the name of "woven air" as the gauzes of the island of Cos. This, of course, is a mere question of manufacture, 
apart from the domain of art. Embroideries and tapestries were not commonly used in Egypt till about the end of the Persian period, or the beginning of the period of Greek rule. Alexandria became partly peopled by Phœenician, Syrian, and Jewish colonists, who brought with them the methods of manufacture peculiar to their own countries, and founded workshops which soon developed into flourishing establishments. It is to the Alexandrians that Pliny ascribes the invention of weaving with several warps, thus producing the stuff called brocades (polymita); and in the time of the first Cæsars, it was already a recognised fact that "the needle of Babylon was henceforth surpassed by the comb of the Nile." The Alexandrian tapestries were not made after exclusively geometrical designs, like the products of the old Egyptian looms; but, according to the testimony of the ancients, were enriched with figures of animals, and even of men. Of the masterpieces which adorned the palaces of the Ptolemies no specimens remain. A few fragments which may be attributed to the later Roman time have, however, been found in Egypt, such as the piece with the boy and goose described by Wilkinson, and a piece representing marine divinities bought by myself at Coptos.* The numerous embroidered winding sheets with woven borders which have recently been discovered near Ekhmeem, and in the

* An unusually fine specimen of carpet, or tapestry work from Ekhmeem, representing Cupids rowing in papyrus skiffs, landscapes, etc., has recently been presented to the British Museum by the Rev. G. J. Chester. The tapestry found at Ekhmeem is, however, all of the Christian period, and this specimen probably dates from about A.D. 700 or A.D. 600. [Translator's note.] 
Fayoom, are nearly all from Coptic tombs, and are more nearly akin to Byzantine art than to the art of Egypt.

\section{3.-METALS.}

The Egyptians classified metals under two headsnamely, the noble metals, as gold, electrum, and silver ; and the base metals, as copper, iron, lead, and, at a later period, tin. The two lists are divided by the mention of certain kinds of precious stones, such as lapis lazuli and malachite.

Iron was reserved for weapons of war, and tools in use for hard substances, such as sculptors' and masons' chisels, axe and adze heads, knife-blades, and saws. Lead was comparatively useless, but was sometimes used for inlaying temple-doors, coffers, and furniture. Also small statuettes of gods were occasionally made in this metal, especially those of Osiris and Anubis. Copper was too yielding to be available for objects in current use; bronze, therefore, was the favourite metal of the Egyptians. Though often affirmed, it is not true that they succeeded in tempering bronze so that it became as hard as iron or steel; but by varying the constituents and their relative proportions, they were able to give it a variety of very different qualities. Most of the objects hitherto analysed have yielded precisely the same quantities of copper and tin commonly used by the bronze founders of the present day. Those analysed by Vauquelin in I825 contained 84 per cent. of copper, I 4 per cent. of tin, and I per cent. of iron and other 
substances. A chisel brought from Egypt by Sir Gardner Wilkinson contained only from 5 to 9 per cent. of tin, I per cent. of iron, and 94 of copper. Certain fragments of statuettes and mirrors more recently subjected to analysis have yielded a notable quantity of gold and silver, thus corresponding with the bronzes of Corinth. Other specimens resemble brass, both in their colour and substance. Many of the best Egyptian bronzes offer a surprising resistance to damp, and oxidise with difficulty. While yet hot from the mould, they were rubbed with some kind of resinous varnish which filled up the pores and deposited an unalterable patina upon the surface. Each kind of bronze had its special use. The ordinary bronze was employed for weapons and common amulets; the brazen alloys served for household utensils; the bronzes mixed with gold and silver were destined only for mirrors, costly weapons, and statuettes of value. In none of the tomb-paintings which I have seen is there any representation of bronze-founding or bronzeworking ; but this omission is easily supplemented by the objects themselves. Tools, arms, rings, and cheap vases were sometimes forged, and sometimes cast whole in moulds of hard clay or stone. Works of art were cast in one or several pieces according to circumstances; the parts were then united, soldered, and retouched with the burin. The method most frequently employed was to introduce a core of mixed clay and charcoal, or sand, into the mould, which roughly reproduced the external modelling. The layer of metal outside this core was often so thin that it would have yielded to any moderate pressure, had they 
not taken the precaution to consolidate it by having the core for a support.

Domestic utensils and small household instruments were mostly made in bronze. Such objects are exhibited by thousands in our museums, and frequently figure in bas-reliefs and mural paintings. Art and trade were not incompatible in Egypt;

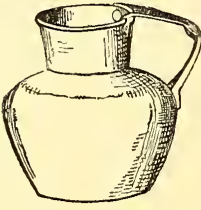

Fig. 267 . and even the coppersmith sought to give elegance of form, and to add ornaments in a good style, to the humblest of his works. The saucepan in which the cook of Rameses III. concocted his masterpieces is supported on lions' feet. Here is a hot-water jug which looks as if it were precisely like its modern successors (fig. 267) ; but on a closer examination we shall find that the handle is a full-blown lotus, the petals, which are bent over at an angle to the stalk, resting against the edge of the neck (fig. 268). The handles of knives and spoons are almost always in the form of a duck's or goose's neck, slightly curved. The bowl is sometimes fashioned like an animal-as, for instance, a gazelle ready bound for the sacrifice (fig. 269).* On the hilt of a sabre we find a little crouching jackal; and the larger limb of a pair of scissors

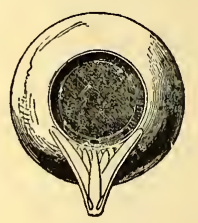

Fig. 268. in the Boulak Museum is made in the likeness of an Asiatic captive, his arms tied behind his back. A lotus leaf forms the disc of a mirror, and its stem is the handle.

* This, however, is a lamp with hook for suspension. Mr. Petrie found a somewhat similar lamp in the cellar of Bakakhiu's house at Tanis: see Tanis, Part I. [Translator's note.] 
One perfume box is a fish, another is a bird, another is a grotesque deity. The lustration vases, or situla, carried by priests and priestesses for the purpose of sprinkling either the faithful, or the ground traversed by religious processions, merit the special consideration of connoisseurs. They are ovoid or pointed at the bottom, and decorated with subjects either chased or in relief. These sometimes represent deities, each in a separate frame, and sometimes scenes of worship. The work is generally very minute.

Bronze came into use for statuary purposes from a very early period; but time unfortunately has preserved none of those idols which peopled the temples of the ancient empire. Whatsoever may be said to the contrary, we possess no bronze statuettes of any period anterior to the expulsion of the Hyksos. Some Theban figures date quite certainly from the Eighteenth and Nineteenth Dynasties. The chased lion's head found with the jewels of Queen Aahhotep, the Harpocrates of Boulak inscribed with the names of Kames and Ahmes I., and several statuettes of Amen, said to have been discovered at Medinet-Haboo and

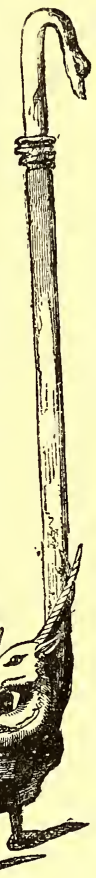

Fig. 269. Sheykh Abd-el-Gourneh, are of that period. Our most important bronzes belong, however, to the Twentysecond Dynasty, or, later still, to the time of the Saïte Pharaohs. Many are not older than the first Ptolemies. A fragment found in the ruins of Tanis, 
and now in the possession of Count Stroganoff, formed part of a votive statue dedicated by King Pisebkhanu. It was originally two-thirds the size of life, and is

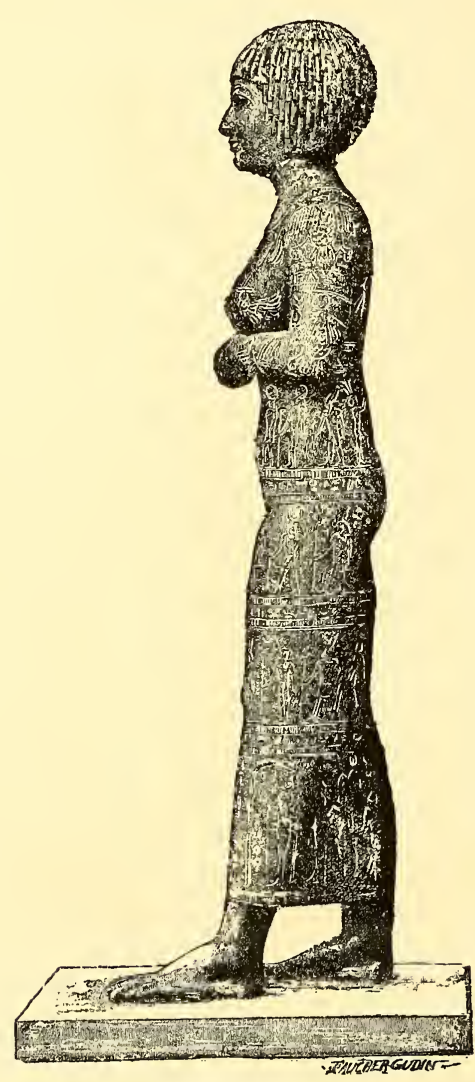

Fig. 270. the largest specimen known. A portrait statuette of the Lady Takoushet, given to the Museum of Athens by M. Demetrio, the four statuettes from the Posno collection now at the Louvre, and the kneeling genius of Boulak, are all from the site of Bubastis, and date probably from the years which immediately preceded the accession of Psammetichus I. The Lady Takoushet is standing, the left foot advanced, the right arm hanging down, the left raised and brought close to the body (fig. 270). She wears a short robe embroidered with religious subjects, and has bracelets on her arms and wrists. Upon her head she has a wig with flat curls, row above row. The details both of her robe and jewels 
are engraved in incised lines upon the surface of the bronze, and inlaid with silver threads. The face is evidently a portrait, and represents a woman of mature age. The form, according to the traditions of Egyptian art, is that of a younger woman, slender, firm, and supple. The copper in this bronze is largely intermixed with gold, thus producing a chastened lustre which is admirably suited to the richness of the embroidered garment. The kneeling genius of Boulak is as rude and repellent as the Lady Takoushet is delicate and harmonious. He has a hawk's head, and he worships the sun, as is the duty of the Heliopolitan genii. His right arm is up-

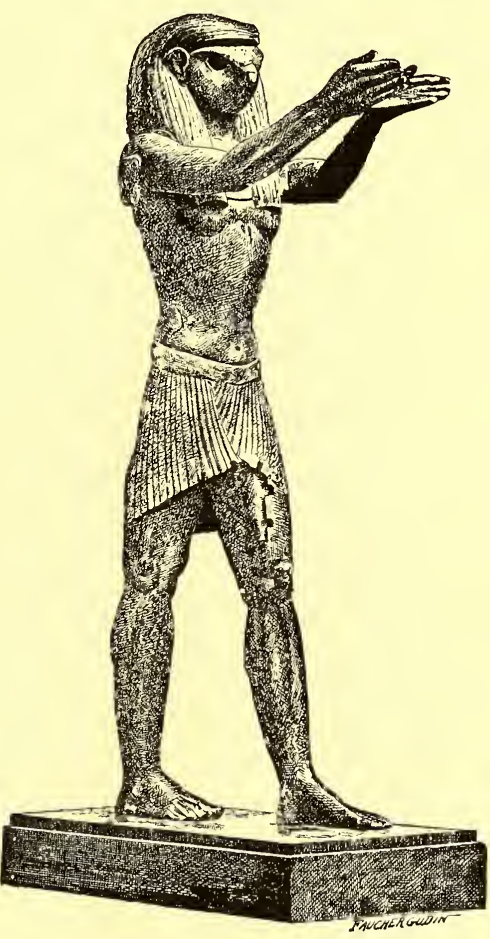

Fig. 271 . lifted, his left is pressed to his breast. The style of the whole is dry, and the granulated surface of the skin adds to the hard effect of the figure. The action, however, is energetic and correct, and the bird's head is adjusted with surprising skill to the man's neck 
and shoulders. The same qualities and the same faults distinguish the Horus of the Posno collection (fig. 27I). Standing, he uplifts a libation vase, now lost, and pours the contents upon a king who once stood face to face with him. This roughness of treatment is less apparent in the other three Posno figures;

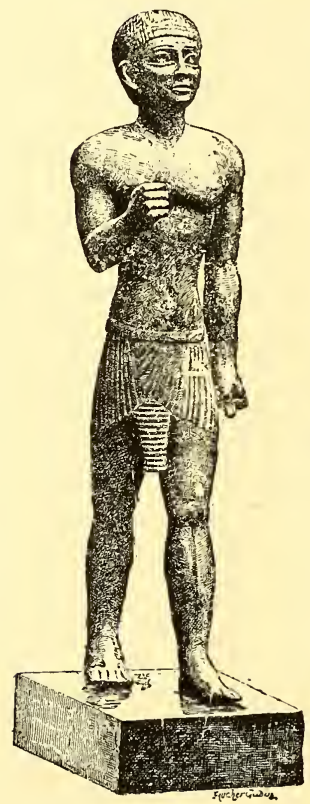

Fig. 272. above all in that which bears the name of Mosou engraved over the place of the heart (fig. 272). Like the Horus, this Mosou stands upright, his left foot advanced, and his left arm pendent. His right hand is raised, as grasping the wand of office. The trunk is naked, and round his loins he wears a striped cloth with a squared end falling in front. His head is clad in a short wig covered with short curls piled one above the other. The ear is round and large. The eyes are well opened, and were originally of silver; but have been stolen by some Arab. The features have a remarkable expression of pride and dignity. After these, what can be said for the thousands of statuettes of Osiris, of Isis, of Nephthys, of Horus, of Nefer-Tum, which have been found in the sands and ruins of Sakkarah, Bubastis, and other cities of the Delta? Many are, without doubt, charming objects for' glass-cases, and are to be admired for perfection of casting and deli- 
cacy of execution; but the greater number are mere articles of commerce, made upon the same pattern, and perhaps in the self-same moulds, century after century, for the delight of devotees and pilgrims. They are rounded, vulgar, destitute of originality, and have no more distinction than the thousands of coloured statuettes of saints and Virgins which stock the shelves of our modern dealers in pious wares. An exception must, however, be made in favour of the images of animals, such as rams, sphinxes, and lions, which to the last retained a more pronounced stamp of individuality. The Egyptians had a special predilection for the feline race. They have represented the lion in every attitude-giving chase to the antelope; springing upon the hunter; wounded, and turning to bite his wound; couchant, and disdainfully calm-and no people have depicted him with a more thorough knowledge of his habits, or with so intense a vitality. Several gods and goddesses, as Shu, Anhur, Bast, Sekhet, Tefnut, have the form of the lion or of the cat; and inasmuch as the worship of these deities was more popular in the Delta than elsewhere, so there never passes a year when from amid the ruins of Bubastis, Tanis, Mendes, or some less famous city, there is not dug up a store of little figures of lions and lionesses, or of men and women with lions' 'heads, or cats' heads. The cats of Bubastis and the lions of Tell-es-Seba crowd our museums. The lions of Horbeyt may be reckoned among the chefs-d'cuvre of Egyptian statuary. Upon one of the largest among them is inscribed the name of Apries (fig. 273); but if even this evidence were lacking, the style of the piece would compel us to 
attribute it to the Saïte period. It formed part of the ornamentation of a temple, or naos, door; and the other side was either built into a wall or imbedded in a piece of wood. The lion is caught in a trap, or, perhaps, lying down in an oblong cage, with only his head and fore feet outside. The lines of the body are simple and full of power; the expression of the face is calm and strong. In breadth and majesty he almost equals the fine limestone lions of Amenhotep III.

The idea of inlaying gold and other precious metals

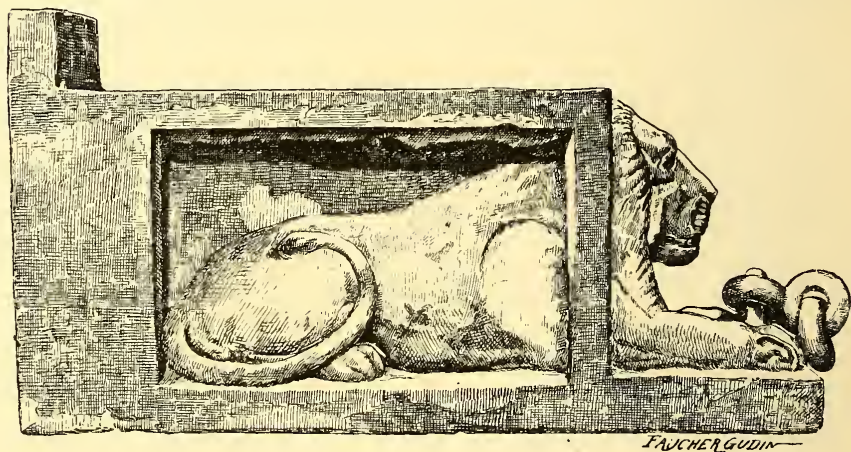

Fig. 273 .

upon the surface of bronze, stone, or wood was already ancient in Egypt in the time of Cheops. The gold is often amalgamated with pure silver. When amalgamated to the extent of 20 per cent. it changes its name, and is called electrum (asimu). This electrum is of a fine light-yellow colour. It pales as the proportion of silver becomes larger, and at 60 per cent. it is nearly white. The silver came chiefly from Asia, in rings, sheets, and bricks of standard weight. The gold and electrum came partly from Syria in bricks 
and rings; and partly from the Soudan in nuggets and gold-dust. The processes of refining and alloying are figured on certain monuments of the early dynasties. In a bas-relief at Sakkarah, we see the weighed gold entrusted to the craftsman for working; in another example (at Beni-Hassan) the washing and melting down of the ore is represented; and again at Thebes, the goldsmith is depicted seated in front of his crucible, holding the blow-pipe to his lips with the left hand, and grasping his pincers with the right, thus fanning the flame, and at the same time making ready to seize the ingot (fig. 274). The Egyptians struck neither coins nor medals. With these exceptions, they made the same use of the precious metals as we do ourselves. We gild the crosses and cupolas of our churches; they covered the doors of their temples, the lower part of their

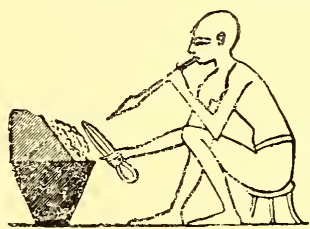

Fig. 274. wall-surfaces, certain bas-reliefs, pyramidions of obelisks, and even whole obelisks, with plates of gold. The obelisks of Queen Hatshepsu at Karnak were coated with electrum. "They were visible from both banks of the Nile, and when the sun rose between them as he came up from the heavenly horizon, they flooded the two Egypts with their dazzling rays."* These plates of metal were forged with hammer and anvil. For smaller objects, they made use of little pellets beaten flat between two pieces of parchment. In the

* From the inscription upon the obelisk of Hatshepsu which is still erect at Karnak. For a translation in full see Records of the Past, vol. xii., p. I3I, et seqq. [Translator's note.] 
Museum of the Louvre we have a gilder's book, and the gold-leaf which it contains is as thin as the goldleaf used by the German goldsmiths of the past century. Gold was applied to bronze surfaces by means of an ammoniacal solvent. If the object to be gilt were a wooden statuette, the workman began by sticking a piece of fine linen all over the surface, or by covering it with a very thin coat of plaster; upon this he laid his gold or silver leaf. It was thus that wooden statuettes of Thoth, Horus, and Nefer-Tum were gilded, from the time of Cheops. The Temple of Isis, the "Lady of the Pyramid," contained a dozen such images; and this temple was not one of the largest in the Memphite necropolis. There would seem to have been hundreds of gilded statues in the Theban temples, at all events in the time of the victorious dynasties of the new empire; and as regards wealth, the Ptolemaic sanctuaries were in no wise inferior to those of the Theban period.

Bronze and gilded wood were not always good enough for the gods of Egypt. They exacted pure gold, and their worshippers gave them as much of it as possible. Entire statues of the precious metals were dedicated by the kings of the ancient and middle empires; and the Pharaohs of the Eighteenth and Nineteenth Dynasties, who drew at will upon the treasures of Asia, transcended all that had been done by their predecessors. Even in times of decadence, the feudal lords kept up the traditions of the past, and, like Prince Mentu-em-hat, replaced the images of gold and silver which had been carried off from Karnak by the generals of Sardanapalus at the time of the Assyrian 
invasions. The quantity of metal thus consecrated to the service of the gods must have been considerable. If many figures were less than an inch in height, many others measured three cubits, or more. Some were of gold, some of silver; others were part gold and part silver. There were even some which combined gold with sculptured ivory, ebony, and precious stones, thus closely resembling the chryselephantine statues of the Greeks. Aided by the bas-relief subjects of Karnak, Medinet-Haboo, and Denderah, as well as by the statues in wood and limestone which have come down to our day, we can tell exactly what they were like. However the material might vary, the style was always the same. Nothing is more perishable than works of this description. They are foredoomed to destruction by the mere value of the materials in which they are made. What civil war and foreign invasion had spared, and what had chanced to escape the rapacity of Roman princes and governors, fell a prey to Christian iconoclasm. A few tiny statuettes buried as amulets upon the bodies of mummies, a few domestic divinities buried in the ruins of private houses, a few ex-votos forgotten, perchance, in some dark corner of a fallen sanctuary, have escaped till the present day. 'The Ptah and Amen of Queen Aah-hotep, another golden Amen also at Boulak, and the silver vulture found in I 885 at Medinet-Haboo, are the only pieces of this kind which can be attributed with certainty to the great period of Egyptian art. The remainder are of Saïte or Ptolemaic work, and are remarkable only for the perfection with which they are wrought. The gold and silver vessels used in the service of the temples, and in 
the houses of private persons, shared the fate of the statues. At the beginning of the present century, the Louvre acquired some flat-bottomed cups which Thoth-

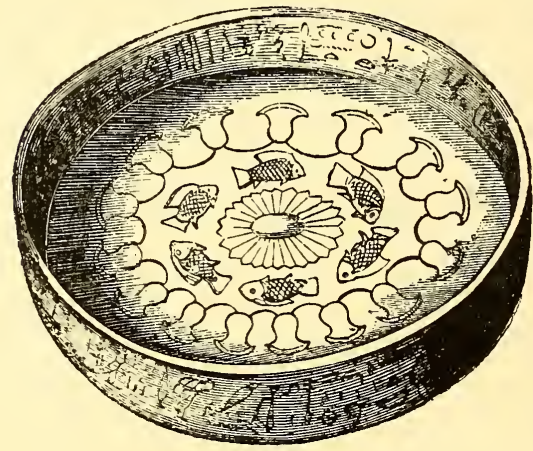

Fig. 275 . mes III. presented as the reward of valour to one of his generals named Tahuti. The silver cup is much mutilated, but the golden cup is intact and elegantly designed (fig. 275). The upright sides are adorned with

a hieroglyphic legend. A central rosette is engraved at the bottom. Six fish are represented in the act of swimming round the rosette; and these again are surrounded by a border of lotus-bells united by a curved line. The five silver vases of Thmuis, in the Boulak Museum, are of silver. They formed part of the treasure of the temple, and had been buried in a hiding-place, where they remained till our own day. We have no indication of their probable age; but whether they

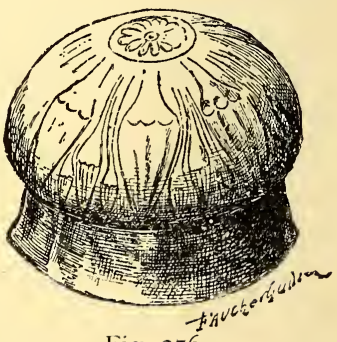

Fig. 276 . belong to the Greek or the Theban period, the workmanship is purely Egyptian. Of one vessel, only the cover is left, the handle being formed of two flowers upon one stem. The others are perfect, and are 
decorated in repoussé work with lotus-lilies in bud and blossom (fig. 276). The form is simple and elegant; the ornamentation sober and delicate; the relief low. One is, however, surrounded by a row of ovoid bosses (fig. 277), which project in high relief, and somewhat alter the shape of the body of the vase. These are interesting specimens; but they are so few in number that, were it not for the wall-paintings, we should have but a very imperfect idea of the skill of the Egyptian goldsmiths.

The Pharaohs had not our

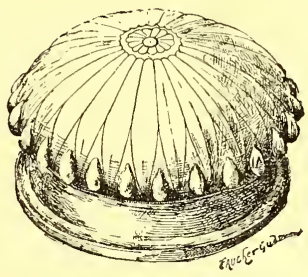

Fig. 277 . commercial resources, and could not circulate the gold and silver tribute-offerings of conquered nations in the form of coin. When the gods had received their share of the booty, there was no alternative but to melt the rest down into ingots, fashion it into personal orna-

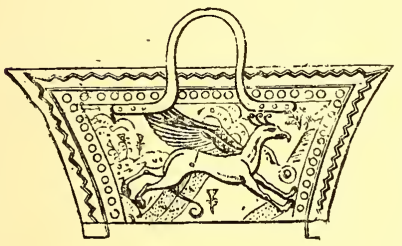

Fig. 278 . ments, or convert it into gold and silver plate. What was true of the kings held good also for their subjects. For the space of at least six or eight centuries, dating from the time of Ahmes I., the taste for plate was carried to excess. Every good house was not only stocked with all that was needful for the service of the table, such as cups, goblets, plates, ewers, and ornamental baskets chased with figures of fantastic animals (fig. 278); but also with large ornamental vases which were dressed with 
flowers, and displayed to visitors on gala days. Some

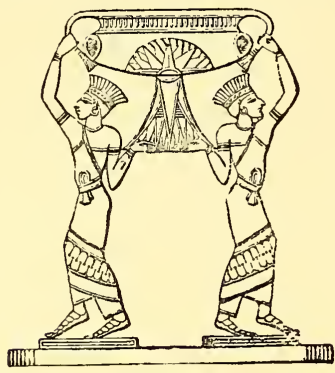

Fig. 279.

of these vases were of extraordinary richness. Here, for instance, is a crater, the handles modelled as two papyrus buds, and the foot as a full-blown papyrus. Two Asiatic slaves in sumptuous garments are represented in the act of upheaving it with all their strength. Here, again, is a kind of hydria,

with a lid in the form of an inverted lotus flanked by the heads of two gazelles (fig. 280). The heads and necks of two horses, bridled and fully caparisoned, stand back to back on either side of the foot of the vase. The body is divided into a series of horizontal zones, the middle zone

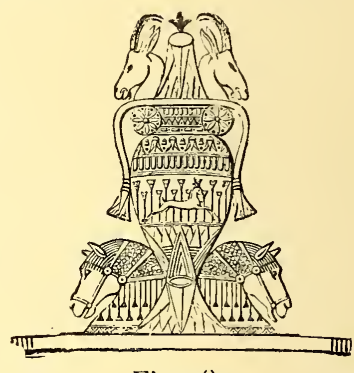

Fig. 280.

being in the likeness of a marshland, with an antelope coursing at full speed among the reeds. Two enamelled cruets have elaborately wrought lids, one fashioned as the head of a plumed eagle, and the other as the head of the god Bes flanked by two vipers. But foremost among them all is a golden centrepiece offered by a viceroy of Ethiopia to Amenhotep III. The design reproduces one of the most popular subjects connected with Fig. 28I.

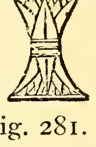

the foreign conquests of Egypt (fig. 283). Men and 
apes are seen gathering fruits in a forest of Dôm palms. Two natives, each with a single feather on his head and a striped kilt about his loins, lead tame giraffes with halters. Others, apparently of the same nationality, kneel with upraised hands, as if begging for quarter. Two negro prisoners lying face downwards upon the ground, lift their heads with difficulty. A large vase with a short foot and a lofty coneshaped cover stands amid the trees. The craftsmen who made this vase evidently valued elegance and beauty less than richness. They cared little for the heavy effect and bad taste of the whole, provided only that they were praised for their skill,

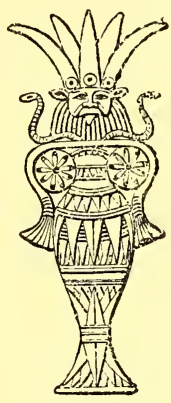

Fig. 282. and for the quantity of metal which they had succeeded in using. Other vases of the same type, pictured in a scene of presentations to Rameses II. in the great temple of Aboo Simbel, vary the subject by showing

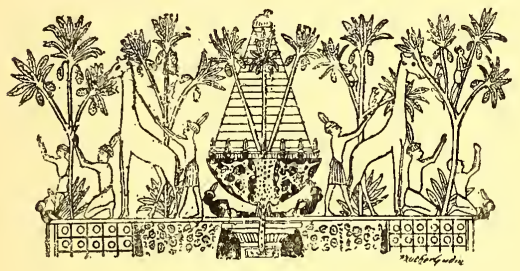

Fig. 283 . buffaloes running in and out among the trees, in place of led giraffes. These were costly playthings wrought in gold, such as the Byzantine emperors of the ninth century accumulated in their palace of Magnaura, and which they exhibited on state occasions in order to impress foreigners with a profound sense of their riches and power. When a victorious Pharaoh returned from a distant campaign, the vessels of gold and 
silver which formed part of his booty figured in the triumphal procession, together with his train of foreign

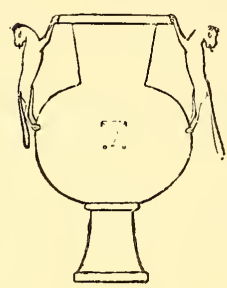

Fig. 284. captives. Vases in daily use were of slighter make and less encumbered with inconvenient ornaments. The two leopards which serve as handles to a crater of the time of Thothmes III. (fig. 284) are not well proportioned, neither do they combine agreeably with the curves of the vase; but the accompanying cup (fig. 285), and a cruet belonging to the same service (fig. 286), are very happily conceived, and have much purity of form. These vessels of engraved and repoussé gold and silver, some representing hunting scenes and incidents of battle, were imitated by Phœnician craftsmen, and, being exported to Asia Minor, Greece, and Italy,

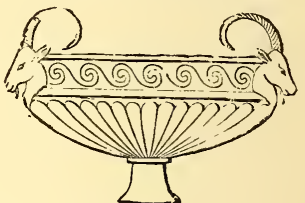

Fig. 285 . carried Egyptian patterns and subjects into distant lands. The passion for preciqus metals was pushed to such extremes under the reigns of the Ramessides that

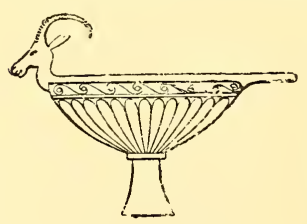

Fig. 286. it was no longer enough to use them only at table. Rameses II. and Rameses III. had thrones of gold-not merely of wood plated with gold, but made of the solid metal and set with precious stones. These things were too valuable to escape destruction, and were the first to disappear. Their artistic value, however, by no means equalled their intrinsic value, and the loss is not one for which we need be inconsolable. 
Orientals, men and women alike, are great lovers of jewellery. The Egyptians were no exception to this rule. Not satisfied to adorn themselves when living with a profusion of trinkets, they loaded the arms, the fingers, the neck, the ears, the brow, and the ankles of their dead with more or less costly ornaments. The quantity thus buried in tombs was so considerable that even now, after thirty centuries of active search, we find from time to time mummies which are, so to say, cuirassed in gold. Much of this funerary jewellery was made merely for show on the day of the funeral, and betrays its purpose by the slightness of the workmanship. The favourite jewels of the deceased person were, nevertheless, frequently buried with him, and the style and finish of these leave nothing to be desired. Chains and rings have come down to us in large numbers, as indeed might be expected. The ring, in

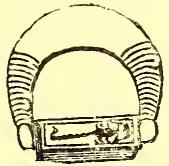

Fig. 287. fact, was not a simple ornament, but an actual necessary. Official documents were not signed, but sealed; and the seal was good in law. Every Egyptian, therefore, had his seal, which he kept about his person, ready for use if required. The poor man's seal was a simple copper or silver ring; the ring of the rich man was a more or less elaborate jewel covered with chasing and relief work. The bezel was movable, and turned upon a pivot. It was frequently set with some kind of stone engraved with the owner's emblem or device; as, for example, a scorpion (fig. 287), a lion, a hawk, or a cynocephalus ape. As in the eyes of her husband his ring was the one essential ornament, so was her chain in the estimation of the Egyptian lady. 
I have seen a specimen in silver which measured sixtythree inches in length. Others, on the contrary, do not exceed two, or two and a half inches. They are of all sizes and patterns, some consisting of two or three twists, some of large links, some of small links, some massive and heavy, others as light and flexible as the finest Venetian filigree. The humblest peasant girl, as well as the lady of highest rank, might have her necklet; and the woman must be poor indeed whose little store comprised no other ornament. No mere catalogue of bracelets, diadems, collarettes, or insignia of nobility could give an idea of the number and variety of jewels known to us by pictured representations or existing specimens. At Berlin may be seen the parure of an Ethiopian Candace; at the Louvre we have the jewels of Prince Psar; at Boulak are preserved the ornaments of Queen Aah-hotep, the most complete of all. Aah-hotep was the wife of Kames, a king of the Seventeenth Dynasty, and she was probably the mother of Ahmes I.* Her mummy had been stolen by one of the robber bands which infested the Theban necropolis towards the close of the Twentieth Dynasty. They buried the royal corpse till such time as they might have leisure to despoil it in safety ; and they were most likely seized and executed before they could carry that pretty little project into effect. The secret of their hiding-place perished with them, till discovered in I860 by some Arab diggers. Most of the objects which this queen took with her into the next world were exclusively woman's gear; as a fan-handle plated with gold, a bronze-gilt mirror mounted upon an ebony handle en-

* First king of the Eighteenth Dynasty. [Translator's note.] 
riched with a lotus in chased gold (fig. 288). Her bracelets are of various types. Some are anklets and armlets, and consist merely of plain gold rings, both solid and hollow, bordered with plaited chainwork in imitation of filigree. Others are for wearing on the wrist, like the bracelets of modern ladies, and are made of small beads in gold, lapis lazuli, carnelian, and green feldspath. These are strung on gold wire in a chequer pattern, each square divided diagonally in halves of different colours. Two gold plates, very lightly engraved with the cartouches of Ahmes I., are connected by means of a gold pin, and form the fastening.

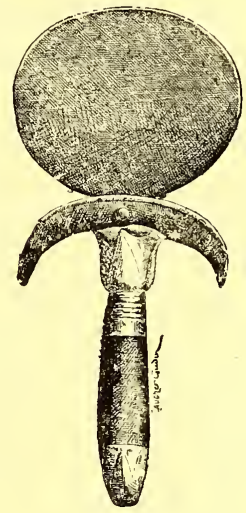

Fig. 288.

A fine bracelet in the form of two semicircles joined by a hinge (fig. 289), also bears the name of Ahmes I.

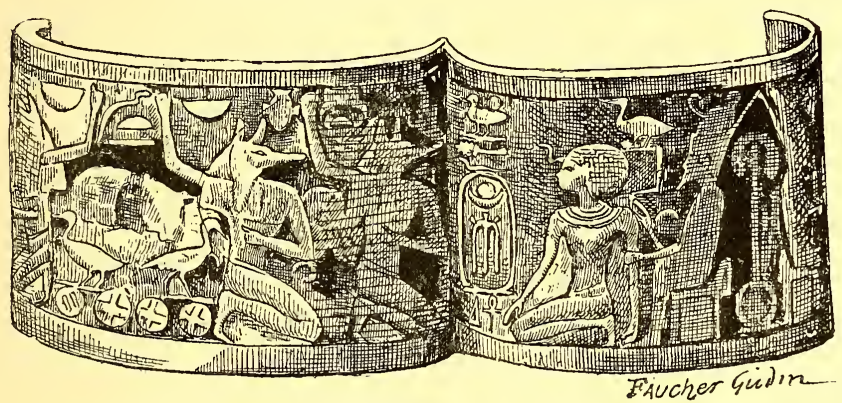

Fig. 289.

The make of this jewel reminds us of cloisonné enamels. Ahmes kneels in the presence of the god Seb and his acolytes, the genii of Sop and Khonu. The figures and 
hieroglyphs are cut out in solid gold, delicately engraved with the burin, and stand in relief upon a groundsurface filled in with pieces of blue paste and lapis lazuli artistically cut. A bracelet of more complicated work-

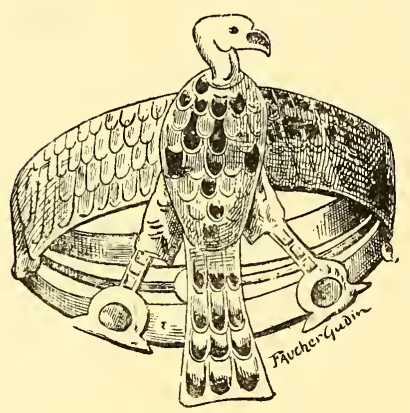

Fig. 290. manship, though of inferior execution, was found on the wrist of the queen (fig. 290). It is of massive gold, and consists of three parallel bands set with turquoises. On the front a vulture is represented with outspread wings, the feathers composed of green enamel, lapis lazuli, and carnelian, set in "cloisons" of gold. The hair of the mummy was drawn through a massive gold diadem, scarcely as large as a bracelet. The name of Ahmes is incrusted in blue paste upon an oblong plaque in the centre, flanked at each side by two little sphinxes which seem as if in the act of keeping watch over the inscription (fig. 29I). Round her neck was a large flexible gold chain, finished at each end by a goose's head reversed.

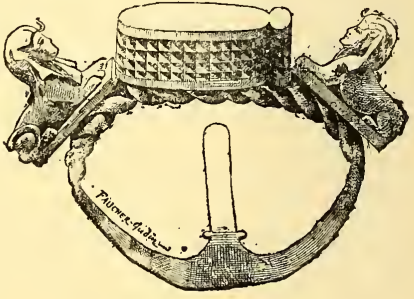

Fig. 29I.

These heads could be linked one in the other, when the chain needed to be fastened. The scarabæus pendant to this chain is incrusted upon the shoulder and wing-sheaths with blue glass paste rayed 
with gold, the legs and body being in massive gold. The royal parure was completed by a large collar of the kind known as "Usekh" (fig. 292). It is finished

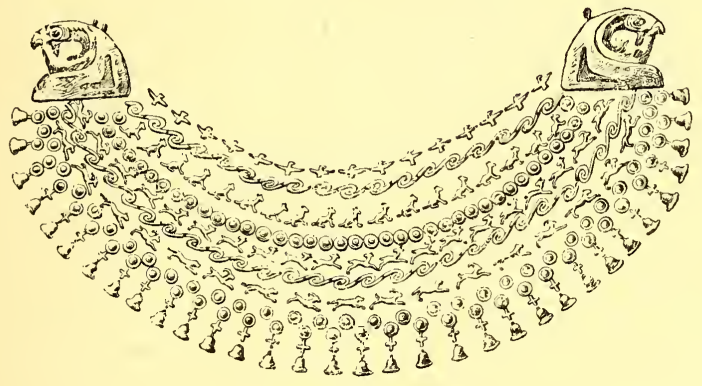

Fig. 292.

at each end with a golden hawk's head inlaid with blue enamel, and consists of rows of scrolls, four-petalled fleurettes, hawks, vultures, winged uræi, crouching jackals, and figures of antelopes pursued by tigers. The whole of these ornaments are of gold repoussé work, and they were sewn upon the royal winding sheet by means of a small ring soldered to the back of each.

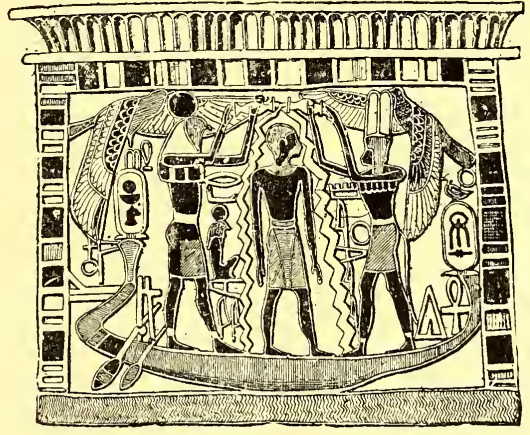

Fig. 293.

Upon the breast, below this collar, hung a square jewel of the kind known as "pectoral ornaments" (fig. 293). The general form is that of a naos, or 
shrine. Ahmes stands upright in a papyrus-bark, between Amen and $\mathrm{Ra}$, who pour the water of purification upon his head and body. Two hawks

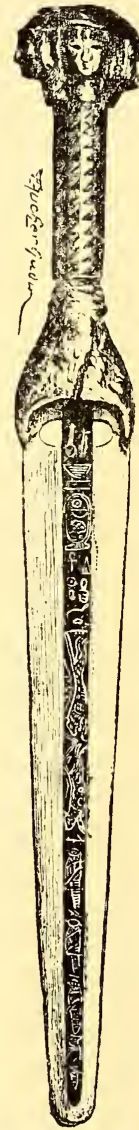
hover to right and left of the king, above the heads of the gods. The figures are outlined in cloisons of gold, and these were filled in with little plaques of precious stones and enamel, many of which have fallen out. The effect of this piece is somewhat heavy, and if considered apart from the rest of the parure, its purpose might seem somewhat obscure. In order to form a correct judgment, we have, however, to remember in what fashion the women of ancient Egypt were clad. They wore a kind of smock of semi-transparent material, which came very little higher than the waist. The chest and bosom, neck and shoulders, were bare; and the one garment was kept in place by only a slender pair of braces. The rich clothed these uncovered parts with jewellery. The Usekh collar half hid the shoulders and chest. The pectoral masked the hollow between the breasts. Sometimes even the breasts were covered with two golden cups, either painted or enamelled. Besides the jewels found upon the mummy of Queen Aah-hotep, a number of arms and amulets were heaped inside her coffin ; namely, three Fig. 294. massive gold flies hanging from a slender chain ; nine small hatchets, three of gold and six of silver; a golden lion's head of very minute workman- 
ship; a wooden sceptre set in gold spirals; two anklets; and two poignards. One of these poignards (fig. 294) has a golden sheath and a wooden hilt inlaid with triangular mosaics of carnelian, lapis lazuli, feldspath, and gold. Four female heads in gold repousse form the pommel; and a bull's head reversed covers the junction of blade and hilt. The edges of the blade are of massive gold; the centre of black bronze damascened with gold. On one side is the solar cartouche of Ahmes, below which a lion pursues a bull, the remaining space being filled in with four grasshoppers in a row. On the other side we have the family name of Ahmes and a series of full-blown flowers issuing one from another and diminishing towards the point. A poignard found at Mycenæ by Dr. Schliemann is similarly decorated. The Phœnicians, who were industrious copyists of Egyptian models, probably introduced this pattern into Greece. The queen's second poignard is of a make not uncommon to this day in Persia and India. The blade is of yellowish bronze fixed into a

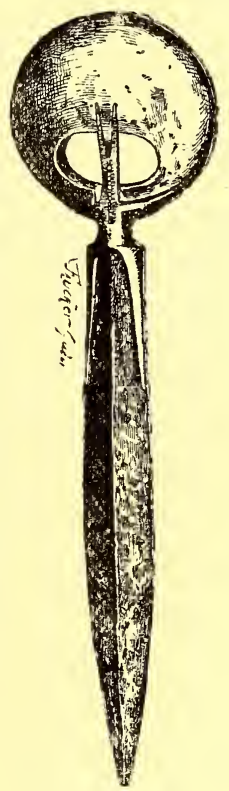

Fig. 295 . disk-shaped hilt of silver. When wielded, this lenticular* disk fits to the hollow of the hand, the blade coming between the first and second fingers. Of what use, it may be asked, were all these weapons to a woman-and a dead woman? To this we may reply that the

* That is, lentil-shaped, or a double convex. [Translator's note.] 
other world was peopled with foes-Typhonian genii, serpents, gigantic scorpions, tortoises, monsters of

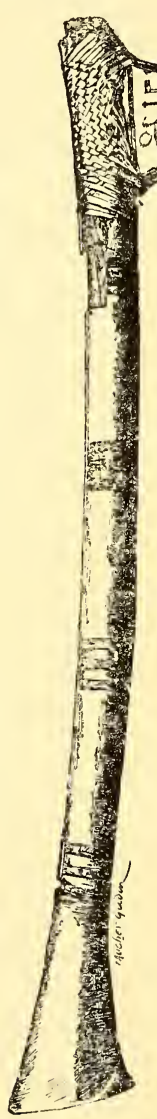

Fig. 296. every description-against which it was incessantly needful to do battle. The poignards placed inside the coffin for the selfdefence of the soul were useful only for fighting at close quarters ; certain weapons of a projectile kind were therefore added, such as bows and arrows, boomerangs made in hard wood, and a war-hatchet. The handle of this hatchet is fashioned of cedar-wood covered with sheet gold (fig. 296). The legend of Ahmes is inlaid thereon in characters of lapis lazuli, carnelian, turquoise, and green feldspath. The blade is fixed in a cleft of the wood, and held in place by a plait-work of gold wire. It is of black bronze, formerly gilt. On one side, it is ornamented with lotus flowers upon a gold ground; on the other, Ahmes is represented in the act of slaying a barbarian, whom he grasps by the hair of the head. Beneath this group, Menthu, the Egyptian war-god; is symbolised by a griffin with the head of an eagle. In addition to all these objects, there were two small boats, one in gold and one in silver, emblematic of the bark in which the mummy must cross the river to her last home, and of that other bark in which 
she would ultimately navigate the waters of the West, in company with the immortal gods. When found, the silver boat rested upon a wooden truck with four bronze wheels; but as it was in a very dilapidated state, it has been dismounted and replaced by the golden boat. The hull is long and slight, the prow and stem are elevated, and terminate in gracefullycurved papyrus blossoms. Two little platforms surrounded by balustrades on a panelled ground, stand at the prow and on the poop, like quarter-decks. The pilot stands upon the one, and the steersman behind

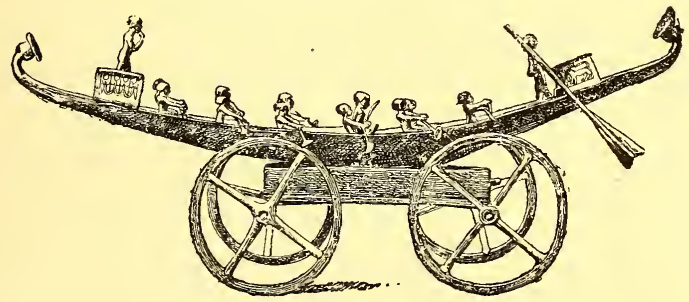

Fig. 297.

the other, with a large oar in his hand. This oar takes the place of the modern helm. Twelve boatmen in solid silver are rowing under the orders of these two officers; Kames himself being seated in the centre, hatchet and sceptre in hand. Such were some of the objects buried with one single mummy; and I have even now enumerated only the most remarkable among them. The technical processes throughout are irreproachable, and the correct taste of the craftsman is in no wise inferior to his dexterity of hand. Having arrived at the perfection displayed in the parure of Aah-hotep, the goldsmith's art did not long maintain 
so high a level. The fashions changed, and jewellery became heavier in design. The ring of Rameses II., with his horses standing upon the bezel (fig. 298), and the bracelet of Prince Psar, with his griffins and lotus flowers in cloisonne enamel (fig. 299), both in the Louvre, are less happily conceived than

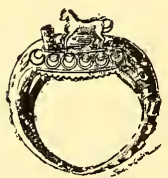
the bracelets of Ahmes. The craftsmen who made these ornaments were doubtless as skilful as the craftsmen of the time of Queen Aah-hotep, but they had less taste Fig. 298. and less invention. Rameses II. was condemned either to forego the pleasure of wearing his ring, or to see his little horses damaged and broken off by the least accident. Already noticeable in the time of the Nineteenth Dynasty, this decadence becomes more marked as we approach the

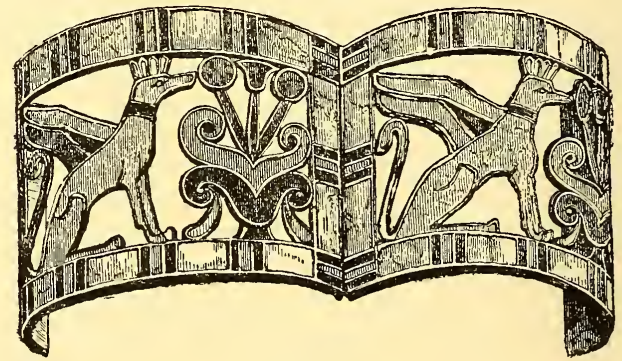

Fig. 299.

Christian era. The earrings of Rameses IX. in the Boulak Museum are an ungraceful assemblage of filigree disks, short chains, and pendent uræi, such as no human ear could have carried without being torn, or pulled out of shape. They were attached 
to each side of the wig upon the head of the mummy. The bracelets of the High Priest Pinotem III., found upon his mummy, are mere round rings of gold incrusted with pieces of coloured glass and carnelian, like those still made by the Soudanese blacks. The Greek invasion began by modifying the style of Egyptian gold-work, and ended by gradually substituting Greek types for native types. The jewels of an Ethiopian queen, purchased from Ferlini by the Berlin Museum, contained not only some ornaments which might readily have been attributed to Pharaonic times, but others of a mixed style in which Hellenic influences are distinctly traceable. The treasure discovered at Zagazig in I878, at Keneh in I88I, and at Damanhour in I882, consisted of objects having nothing whatever in common with Egyptian traditions. They comprise hairpins supporting statuettes of Venus, zone-buckles, agraffes for fastening the peplum, rings and bracelets set with cameos, and caskets ornamerited at the four corners with little Ionic columns. The old patterns, however, were still in request in remote provincial places, and village goldsmiths adhered "indifferent well" to the antique traditions of their craft. Their city brethren had meanwhile no skill to do aught but make clumsy copies of Greek and Roman originals.

In this rapid sketch of the industrial arts there are many lacunæ. When referring to examples, I have perforce limited myself to such as are contained in the best-known collections. How many more might not be discovered if one had leisure to visit provincial museums, and trace what the hazard of sales may have 
dispersed through private collections! The variety of small monuments due to the industry of ancient Egypt is infinite, and a methodical study of those monuments has yet to be made. It is a task which promises many surprises to whomsoever shall undertake it. 


\section{NOTES.}

For the following notes, to which reference numbers will be found in the text, I am indebted to the kindness of $M r . W$. M. Flinders Petrie, author of "The Pyramids and Temples of Gizeh" (Field \& Tuer), "Tanis" (Egypt Exploration Find), "Naukratis" (Egypt Exploration Fund), etc., etc.

A. B. E.

(I) More striking than these are the towns of Tell Atrib, Kom Baglieh, Kom Abu Billu, and Tel Nebesheh, the houses of which may be traced without any special excavations.

(2) There is much skill needed in mixing the mud and sand in such proportions as to dry properly; when rightly adjusted there is no cracking in drying, and the grains of sand prevent the mud from being washed away in the rains.

(3) In the Delta, at least, the sizes of bricks from the Twentyfirst Dynasty down to Arab times decrease very regularly; under the Twenty-first Dynasty they are about $18 \times 9 \times 5$ inches; early in the Twenty-sixth, $16 \frac{1}{2} \times 8 \frac{1}{4} \times 5$; later $15 \times 7 \frac{1}{2}$; in early Ptolemaic times, $14 \times 7$; in Roman times, $12 \times 6$, in Byzantine times, IO $\times 5$; and Arab bricks are $8 \times 4$, and continue so very generally to our times. The thickness is always least certain, as it depends on the amount placed in the mould, but the length and breadth may in most cases be accepted as a very useful chronological scale.

(4) They are found of Ramesside age at Nebesheh and Defenneh; even there they are rare, and these are the only cases I have yet seen in Egypt earlier than about the third century A.D.

(5) This system was sometimes used to raise a fort above the plain, as at Defenneh; or the chambers formed store-rooms, as at the fort at Naukratis. 
(6) In the fine early work at Gizeh they sawed the paving blocks of basalt, and then ground only just the edges flat, while all the inside of the joint was picked rough to hold the mortar.

(7) A usual plan in early times was to dress the joint faces of the block in the quarry, leaving its outer face with a rough excess of a few inches; the excess still remains on the granite casing of the pyramid of Menkara, and the result of dressing it away may be seen in the corners of the granite temple at Gizeh.

(8) Otherwise called the Granite Temple of Gizeh, or Temple of Khafra, as its connection with the Sphinx is much disputed, while it is in direct communication with the temple of the pyramid of Khafra, by a causeway in line with the entrance passage.

(9) The casing of the open air court on the top of it was of fine limestone; only a few blocks of this remain. For full plan and measurements see Pyramids and Temples of Gizeh.

(Io) One of the air slits, or ventilators, remains complete, opening to the upper court, from the top of the niche chamber.

(I I) Below these lines, there is often a scene of offering at the bottom of the Obelisk.

(I2) Mastaba is the Arabic name for a bench or platform, and was applied by the natives to such tombs on account of the resemblance in shape.

(13) In the few cases where the top remains perfect at Gizeh, the side ends in a parabolic curve which turns over into the top surface without any cornice or moulding; the tops of walls in the courts of mastabas are similar.

(14) Another view is that they are derived from the cumulative mastabas, such as the so-called step pyramid of Sakkarah.

(15) In the later pyramids; but the Gizeh pyramids are entirely built of Toorah limestone.

(16). Still more conclusive is the fact that in the greatest of the pyramids the passages are such that it would have been impossible to build it by successive coats of enlargement.

(I7) In only one case (that of Menkara) has a pyramid been clearly enlarged, and that was done at one step and not by many stages.

(I8) The earliest-at Gizeh-are very accurate.

(19) These slabs of pavement do not extend beneath the pyramid, but only around it. 
(20) Only fragments of the finest limestone casing have been found ; the variety of colour was probably due'to weathering.

(2I) This would be impossible with the exquisitely fine joints of the masonry; a temporary staging of stone built up over part of the finished face would easily allow of raising the stones.

(22) There is no evidence that the facing block which covered the granite plugs was of granite; it was more probably of limestone.

(23) The entrance to the upper passages was never forced from the entrance passage, but was accidentally found by the Arabs, after they had forced a long tunnel in the masonry, being in ignorance of the real entrance, which was probably concealed by a hinging block of stone.

(24) Or rather it rose at an angle of $23 \frac{1}{2}^{\circ}$, like the descent of the entrance passage, thus making angles of $47^{\circ}$ and $133^{\circ}$ with it.

(25) This gallery has obtained a great reputation for the fineness of its joints, perhaps because they are coarse enough to be easily seen ; but some joints of the entrance passage, and the joints in the queen's chamber, are hardly visible with the closest inspection.

(26) The only signs of portcullises are those in the vestibule or antechamber.

(27) No traces of three of the portcullises remain, if they ever existed, and the other never could reach the floor or interrupt the passage, so its use is enigmatical.

(28) There is some evidence that the pyramid was opened in the early days, perhaps before the middle kingdom.

(29) Two rows of beams which rest on the side wall as corbels or cantilevers, only touching at the top, without necessarily any thrust. Such at least is the case in the queen's chamber, and in the pyramid of Pepi, where such roof is used.

(30) The end walls have sunk throughout a considerable amount, and the side walls have separated; thus all the beams of the upper chambers have been dragged, and every beam of the roof of the chamber is broken through. This is probably the result of earthquakes.

(3) This only covered the lower sixteen courses; the larger part above it was of limestone.

(32) Similar finished faces may be seen as far in as near the 
middle of the mass. This is not a true pyramid in form, but a cumulative mastaba, the faces of which are at the mastaba angle $\left(75^{\circ}\right)$, and the successive enlargements of which are shown by numerous finished facings now within the masonry. The step form is the result of carrying upwards the mastaba form, at the same time that it was enlarged outwards.

(33) Not in all cases apparently, or the hieroglyphs on the passage of Pepi's pyramid are not injured, as they would be if plugs had been withdrawn.

(34) Pepi's roof is formed by a row of large beams which rested independently on the side walls as corbels or cantilevers (see Note 29).

(35) The mastaba angle is $75^{\circ}$, and the pyramid angle $50^{\circ}$ to $55^{\circ}$ :

(36) Its present appearance is an accident of its demolition; it was originally, like the "step-pyramid" of Sakkarah, a cumulative mastaba, as is shown by the remains of the lower steps still in the mounds at its base, and by the mediæval description of it. 

